Esta tesis doctoral contiene un índice que enlaza a cada uno de los capítulos de la misma.

Existen asimismo botones de retorno al índice al principio y final de cada uno de los capítulos.

$\underline{\text { Ir directamente al índice }}$

Para una correcta visualización del texto es necesaria la versión de Adobe Acrobat Reader 7.0 o posteriores

Aquesta tesi doctoral conté un índex que enllaça a cadascun dels capítols. Existeixen així mateix botons de retorn a l'index al principi i final de cadascun deis capítols .

Anar directament a l'index

Per a una correcta visualització del text és necessària la versió d' Adobe Acrobat Reader 7.0 o posteriors. 
Programa de Doctorat

Física, Enginyeria de Sistemes i Teoria del Senyal

Tesi Doctoral

\section{RETRIEVAL OF BIOPHYSICAL PARAMETERS OF AGRICULTURAL CROPS USING POLARIMETRIC SAR INTERFEROMETRY}
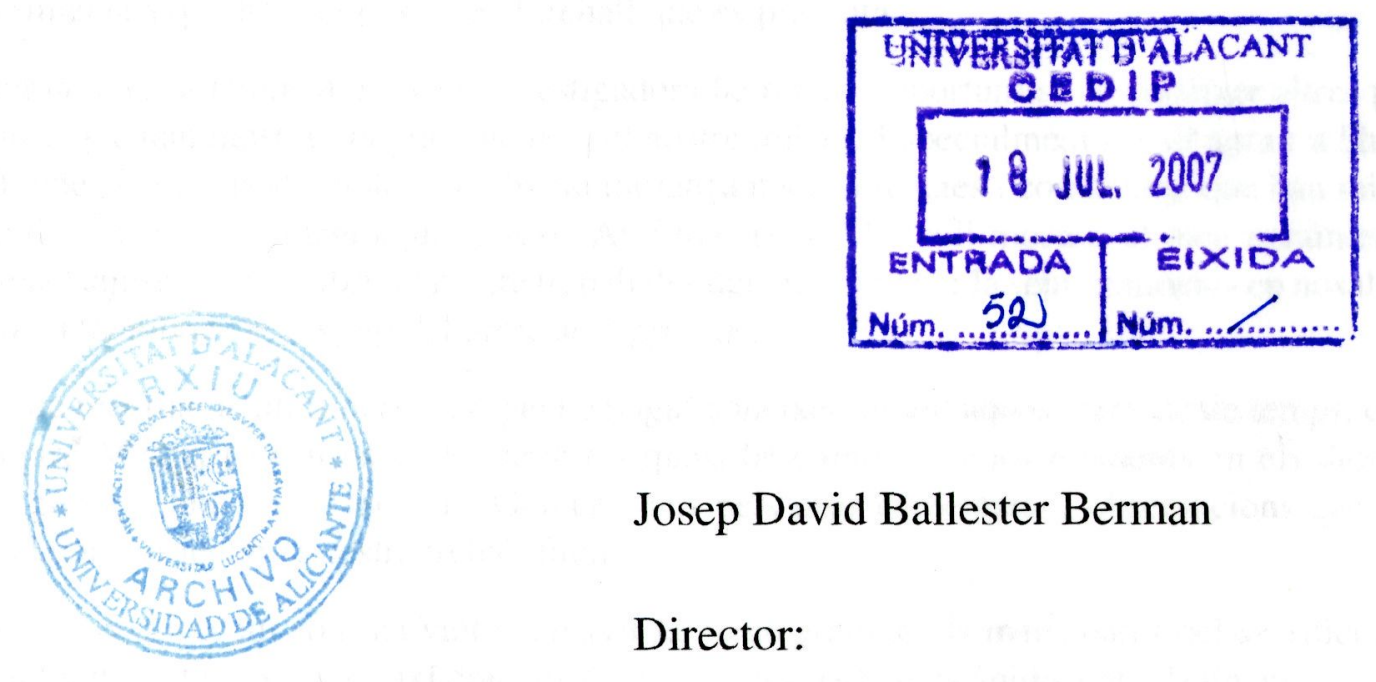

Josep David Ballester Berman

Director:

Juan Manuel López Sánchez

Alacant, juliol 2007 


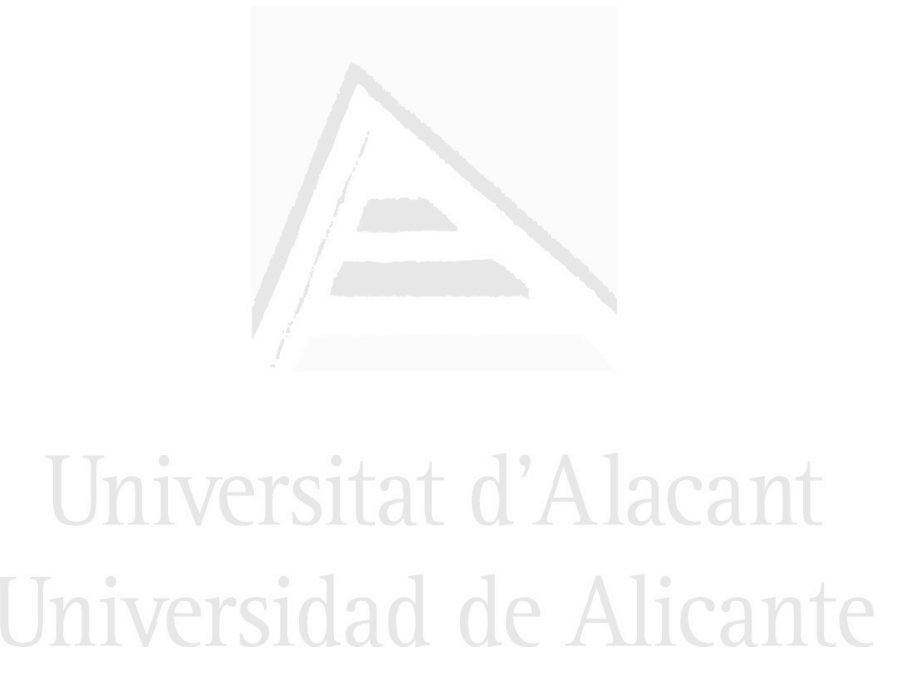

. 


\section{Agraïments}

Aquesta tesi és el resultat del treball d'investigació desenvolupat durant vora quatre anys dins del Grup de Senyals, Sistemes i Telecomunicacions (SST) de la Universitat d'Alacant, amb el finançament públic del Ministeri Espanyol d'Educació i Ciència i EU FEDER amb els projectes TIC2002-04451-C02-02 and TEC2005-06863-C02-02, així com de la Generalitat Valenciana amb el projecte ACOMP07/087.

En primer lloc, voldria expressar el meu agraïment més sincer als meus companys del grup SST pels moments, agradables i no tan agradables, que hem compartit durant tot aquest temps i pel suport personal i els ànims que m'han donat tant en la tasca investigadora com docent.

Molt especialment, li vull agrair a Juanma López el recolzament personal que sempre m'ha mostrat. La seua implicació no només s'ha centrat en la supervisió, sempre rigorosa, pacient i humil, d'aquesta tesi doctoral. El seu compromís i dedicació ha sobrepassat la vessant científica i professional i ha fet possible una inestimable relació de amistat i confiança.

També vull agrair a Joaquim Fortuny el seu assessorament i la col.laboració que hem mantingut durant una important part del desenvolupament de la tesi, així com al European Microwave Signature Laboratory (EMSL), a Ispra, Itàlia, per proporcionar-nos les dades experimentals que han fet possible el treball que es presenta.

Durant aquest temps d'activitat investigadora he tingut l'oportunitat de conèixer altres persones que han mostrat un gran interès pel nostre treball. Especialment li vull agrair a Shane Cloude la seua inestimable contribució mitjançant suggerències i comentaris que han millorat de manera important aquesta tesi. Així mateix, també vull mostrar el meu agraïment a Irena Hajnsek per recolzar el nostre treball des del principi i per la seua confiança en nosaltres com a membres de l'equip del projecte AgriSAR.

He de recordar a altres persones que he pogut conèixer durant aquest període de temps, com Gerard Margarit i Carlos López amb els quals he compartit bons moments en els dies de congressos, així com José Luis Gómez Dans pels seus comentaris i observacions que ens ajudaran a orientar el nostre treball futur.

En una ocasió com aquesta vull expressar la meua gratitud als meus pares pel sacrifici que han fet durant tants anys, així com als meus germans pels seus ànims i recolzament.

Finalment, el major sentiment d'agraïment li'l dec a Estefania i a Francesc. D'ella i d'ell he rebut dia a dia el suport, la comprensió i afectuositat més sincera. 


\section{Acknowledgements}

This thesis is the result of the research work carried out during a period of almost four years as a member of the Systems, Signals and Telecommunication (SST) Group of the University of Alacant, with the public financial support of the Spanish Ministry of Education and Science and EU FEDER under projects TIC2002-04451-C02-02 and TEC2005-06863C02-02, as well as of the Generalitat Valenciana under project ACOMP07/087.

First of all, I would like to express my most sincere thanks to my colleagues of the SST group for the moments, nice and not so nice, that we have shared along this time and for the personal assistance and encouragement they have given to me about my research and educational tasks.

I am specially grateful to Juanma López for his constant personal support. His implication not only has been focused on the supervision, always rigorous, patient and humble, of this doctoral thesis. His commitment and dedication have gone beyond the scientific and professional aspects and this has led to an invaluable relationship of confidence and friendship.

I would like also to gratefully acknowledge to Joaquim Fortuny for his advice and collaboration maintained during an important part of development of the thesis, as well as to the European Microwave Signature Laboratory (EMSL), Ispra, Italy, for providing the experimental data that have made possible the present work.

During this research I have enjoyed the opportunity to meet other people who have shown a great interest in our work. I specially wish to thank Shane Cloude his invaluable contribution by means of suggestions and comments that have greatly improved this thesis. Likewise I am very grateful to Irena Hajnsek for supporting our work from the beginning and her confidence in us to be included in the AgriSAR project team.

I want to remember other people I met within this time, such as Gerard Margarit and Carlos López for sharing with me good moments during congresses, as well as José Luis Gómez Dans for his comments and observations that will help us to guide our future work.

On such a special occasion I wish to express my gratitude to my parents for their sacrifice during so many years, and to my brothers for their encouragement and support.

Finally, I owe to Estefania and Francesc my deepest feeling of gratitude. Day after day I have received from them support, understanding and the most sincere affection. 

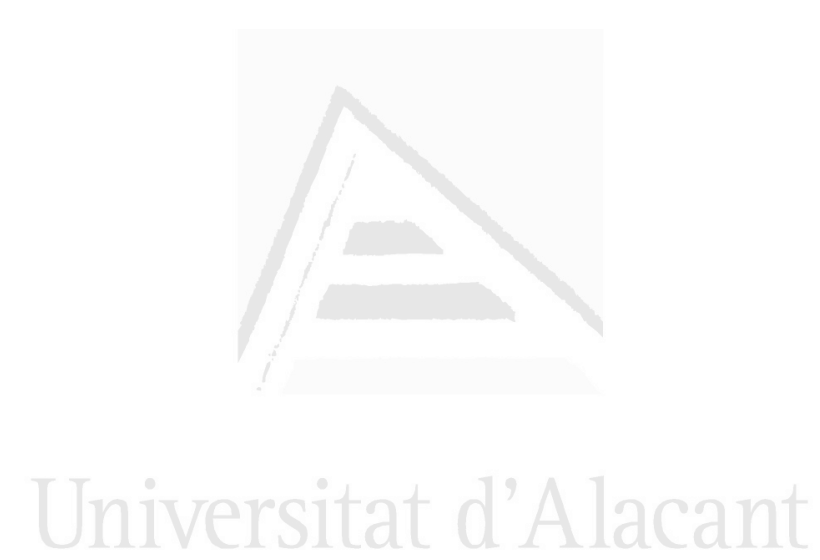


\section{Resum}
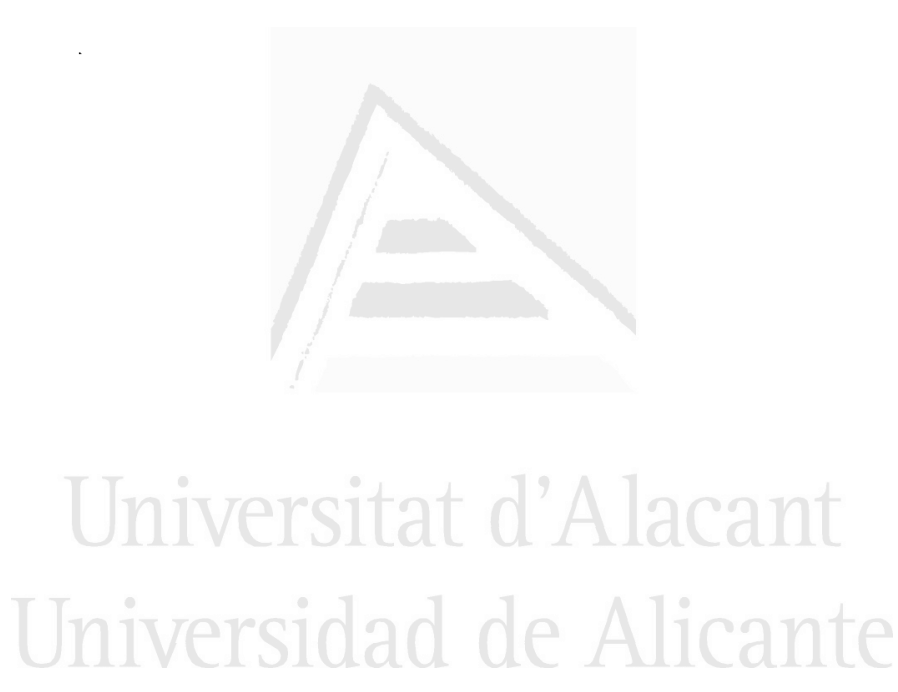

\section{Introducció}

La monitorització de la coberta vegetal terrestre és una important aplicació en el camp de la teledetecció amb microones. Els interessos de la comunitat científica estan enfocats principalment en dos tipus de cobertes vegetals: boscos i cultius. Els boscos es presenten com un factor clau en els estudis de canvi climàtic per la rellevància que suposa la biomassa forestal en el cicle global del carboni. Per altra banda, l'interès en la monitorització dels cultius es justifica en l'impacte econòmic i social que l'activitat agrícola té a molts països. Com a exemple, es pot dir que tres dels quatre estats més poblats del món són societats que es basen en el cultiu de l'arròs: Xina, Índia i Indonèsia, els quals representen vora 2.5 bilions de persones. Com a resultat, el desenvolupament de tècniques per a monitoritzar cultius a gran escala és actualment un objectiu de gran importància a l'hora de gestionar de forma racional els recursos naturals de la Terra.

Els sistemes de teledetecció es poden implementar mitjançant sensors actius o passius depenent de la font d'il.luminació. Els sensors actius estan equipats amb el seu propi sistema d'il.luminació i mesuren la radiació electromagnètica dispersada per l'escena. Per altra banda, els sensors passius fan mesures de la radiació emesa per l'escena o reflectida per altres fonts com el Sol.

Aquests sistemes també es poden classificar segons la banda de frequiències del sensor. En general, els sistemes de teledetecció per a observació de la Terra es poden implementar mitjançant sensors òptics i de microones. Algunes característiques dels sensors actius de microones els converteixen en una eina molt poderosa per a la monitorització de la superfície terrestre, com són la independència de les condicions climatològiques i d'il.luminació, la capacitat de les microones per a penetrar dins l'estructura de la vegetació i l'alta sensibilitat als paràmetres característics dels blancs, com la rugositat o el contingut d'aigua.

Els radars d'obertura sintètica (SAR) constitueixen el punt clau en el desenvolupament de tècniques de monitorització de la superfície terrestre per la capacitat per a proporcionar imatges d'alta resolució en la banda de microones. A més a més, existeixen formes d'obtenir avantatges addicionals dels sistemes SAR mitjançant el post-processat de conjunts d'imatges 
SAR adquirides amb diferents configuracions (frequiència, polarització, angle d'incidència, etc). Per exemple, tres d'aquestes tècniques, les quals es tractaran en aquesta tesi, són: interferometria SAR (InSAR), polarimetria SAR (PolSAR) i interferometria polarimètrica SAR (PolInSAR).

La interferometria SAR ha estat aplicada àmpliament a la generació de Models Digitals del Terreny (DEM) així com a la detecció de canvis en la superfície terrestre, mentre que els sistemes PolSAR s'utilitzen per a extraure paràmetres relacionats amb les propietats físiques dels blancs. En els dos casos s'augmenta la dimensió de l'espai d'observacions i, per tant, millora l'exactitud en l'estimació dels paràmetres biofísics.

Cal tenir en compte que els processos de scattering dins del medi vegetal mostren una alta complexitat a causa de la morfologia vegetal i els complexos processos d'interacció electromagnètica entre els senyals del radar i els elements que formen la vegetació. Com a resultat, els blancs naturals estan caracteritzats per gran quantitat de paràmetres geofísics i biofísics. En els últims deu anys s'ha desenvolupat un grup de tècniques basades en la combinació de la informació polarimètrica i interferomètrica amb l'objectiu de superar algunes de les limitacions dels sistemes InSAR i PolSAR. Aquestes tècniques, conegudes com a PolInSAR, s'implementen amb sensors equipats amb instrumentació multipolarització i, en alguns casos, multi-baseline, és a dir, amb la possibilitat de generar interferogrames amb diferents distàncies (línies de base) del parell d'imatges.

Durant els últims anys diversos sistemes aerotransportats, amb satèl.lit o amb avió, han estat generant mesures polarimètriques i/o interferomètriques, que s'han utilitzat àmpliament per la comunitat científica amb l'objectiu de millorar les tècniques de teledetecció per microones amb sensors actius. La Shuttle Imaging Radar (SIR-C) i la Shuttle Radar Topography Mission (SRTM) van ser missions de transbordador espacial amb capacitat per a operar en els modes repeat-pass i single-pass, respectivament. El primer va fer mesures totalment polarimètriques (quad-pol) a les bandes $\mathrm{L}$ i $\mathrm{C}$, mentre que el segon estava equipat amb un interferòmetre SAR en bandes $\mathrm{C}$ i X, i tenia per objectiu obtenir mapes de la topografia de la superfície terrestre entre les latituds $\pm 60^{\circ}$. A més a més, altres sistemes espacials que han proporcionat dades SAR són ERS-2, treballant en banda C amb el canal VV, Radarsat-1 en banda $\mathrm{C}$ i canal HH, i ASAR (ENVISAT) en banda C proporcionant dades en mode AP, és a dir, un canal copolar i un altre crosspolar.

Més recentment, al 2006 el sistema PALSAR (Phased Array L-band SAR) amb capacitat quad-pol, embarcat en el satèl.lit ALOS desenvolupat per JAXA (Japan Aerospace Exploration Agency) va començar a operar. L'objectiu d'aquest sistema és proporcionar dades d'alta resolució per a la monitorització de desastres naturals i del medi. A més a més, a l'estiu de 2007 està programat el llançament d'un satèl.lit alemany amb el sistema radar TerraSAR$\mathrm{X}$, així com el Radarsat-2 desenvolupat per l'Agència Canadenca de l'Espai. El TerraSAR$X$ transporta un sensor en banda $X$ que treballarà en diversos modes (spotlight, stripmap, scanSAR) i polaritzacions (polarització dual com a mode normal d'operació i quad-pol en mode experimental). Aquest sistema pot operar també com a receptor de mesures radar interferomètriques amb l'objectiu d'implementar interferometria along track per a determinar la velocitat dels blancs. Per altra banda, el Radarsat-2 proporcionarà mesures radar totalment 
polarimètriques en banda $\mathrm{C}$.

Respecte als sistemes transportats en avió, s'han d'esmentar les campanyes de mesures fetes pel E-SAR (Centre Aerospacial Alemany, DLR) així com el sensor AIRSAR (JPL/NASA), els quals tenen capacitat totalment polarimètrica per a fer mesures interferomètriques en les bandes P i L. En el cas del sistema E-SAR, també són possibles combinacions reduïdes de canals de polarització en les bandes S, C i X, mentre que en el cas del sensor AIRSAR és possible obtenir la matriu de scattering completa en banda C. A més a més, una atenció especial mereix el sistema SAR aerotransportat en avió desenvolupat per l'Agència Espacial Francesa (ONERA), anomenat RAMSES, el qual proporciona mesures totalment polarimètriques des de banda $\mathrm{P}$ a banda $\mathrm{Ku}$, així com polaritzacions copolars i circulars per a les bandes $\mathrm{Ka} \mathrm{i} \mathrm{W}$. Addicionalment, les bandes X i Ku s'utilitzen per a implementar interferometria single-pass, tant en mode across-track com en along-track. Un altre exemple de sistema actualment operatiu és el sensor PiSAR de la JAXA/NICT, el qual proporciona dades totalment polarimètriques en les bandes L i X. Finalment, cal nomenar també el sensor EMISAR, del Centre Danès per a Teledetecció (DCRS), que ja està fora de servei i que adquiria dades quad-pol en bandes L i C.

S'ha de tenir en compte que la disponibilitat dels conjunts de dades SAR és escassa ja que aquest tipus de sistemes ha estat desenvolupat molt recentment. A més, en l'actualitat no existeixen satèl.lits operatius amb capacitat de proporcionar dades PolInSAR en el mode single-pass i, per tant, el desenvolupament de tècniques d'inversió paramètrica està encara limitat.

L'estimació dels paràmetres biofísics es basa en un coneixement precís dels mecanismes de dispersió electromagnètica que caracteritzen les cobertes vegetals $i$, com a consequiència d'això, una etapa prèvia abans de la implementació de tècniques fiables per a sistemes aerotransportats consisteix en validar els algoritmes d'inversió en un entorn i condicions controlades.

Aquesta missió s'acompleix mitjançant les simulacions i els radars basats en terra (groundbased radar), els quals s'utilitzen àmpliament amb l'objectiu d'obtenir una descripció precisa de la resposta electromagnètica de blancs naturals $\mathbf{i}$ artificials sense la influència de l'entorn natural. A més a més, aquests sistemes permeten gran flexibilitat en la configuració dels paràmetres, com la frequiència, la polarització i la línia de base (baseline). Per tant, els radars basats en terra s'utilitzen per a estudiar i definir de forma precisa els modes d'operació per a futures missions SAR.

Així doncs, els tests i la validació de les tècniques d'inversió paramètrica de vegetació mitjançant els radars basats en terra formen la part central de la present tesi. Les conclusions obtingudes del treball que es presenta estan fonamentades en l'ús i anàlisi de mesures SAR de banda ampla totalment polarimètriques sobre mostres de cultius de panís i arròs fetes al European Microwave Signature Laboratory (EMSL), Ispra, Itàlia.

A continuació, es descriuen els objectius d'aquesta tesi. 


\section{Objectius de la tesi}

Encara que les tècniques PolInSAR han estat utilitzades amb èxit en l'estimació de paràmetres de zones forestals, l'aplicació no resulta evident quan es tracta d'altres tipus de vegetació, com són el cultius agrícoles, ja que la resposta electromagnètica és molt diferent. Les estructures orientades verticalment que caracteritzen diversos tipus de cultius fan que aquestes morfologies reben el nom de volums orientats. En aquest cas, la propagació electromagnètica és anisòtropa, és a dir, l'atenuació de l'ona a través del volum depén de la polarització. A més a més, l'altura dels cultius és prou reduïda la qual cosa fa que la contribució del sòl siga molt important com a conseqüència de la baixa atenuació durant la propagació a través de la capa vegetal. Per tant, es requereix una anàlisi més profunda sobre el comportament electromagnètic dels cultius agrícoles per tal de caracteritzar-los amb més precisió. Aquesta tasca es pot dur a terme mitjançant el modelatge electromagnètic directe. Com ja s'explicarà al capítol 2, existeixen diferents estratègies per a desenvolupar models directes d'escenes vegetals. Una de les més utilitzades és la que es basa en la descripció estadística de la interacció entre les ones electromagnètiques i el medi natural, la qual no necessita del càlcul de les contribucions de cadascuna de les partícules de scattering que formen el medi. Un altre avantatge important d'aquest mètode estadístic és que permet una interpretació física molt simple de l'escena sota observació, ja que aquesta es descriu mitjançant un conjunt reduït de paràmetres geològics i biològics.

Aquesta estratègia proporciona dos models que tenen en compte diferents tipus de morfologies vegetals, els quals són coneguts com volums aleatoris i volums orientats. En la pràctica, les àrees forestals es poden considerar com una estructura vertical que disposa d'un volum dens localitzat en la part superior de l'escena observada. Aquest volum es tracta com un conjunt de partícules dispersores localitzades i orientades aleatòriament. Així, la propagació de l'ona electromagnètica presenta un comportament isòtrop, és a dir, l'atenuació de l'ona és independent de la polarizació. La capa inferior de l'estructura vertical està formada pel sòl i els troncs dels arbres suficientment separats entre ells. En aquesta part, la resposta electromagnètica està dominada per la interacció sòl-tronc i, com a conseqüència, és possible determinar l'estructura vertical d'aquesta escena mitjançant els observables PolInSAR. Per tant, es pot dir que els boscos es poden modelar com un volum aleatori sobre una superfície de terra (Random Volume over Ground surface -RVoG-). No obstant això, cal tenir en compte que aquesta assumpció de volum aleatori per a zones forestals s'ha de tractar de forma correcta, ja que no és estrictament cert especialment en banda P [BA0I].

Per altra banda, els cultius agrícoles com són el panís, l'arròs o el blat de moro estan formats per estructures amb orientació predominantment vertical, a banda de les fulles i les parts superiors dels talls que estan corbats cap a baix. En aquest cas, la propagació electromagnètica és anisòtropa i, per tant, l'atenuació depén de la polarització. A més a més, la altura curta del volum de vegetació possibilita que les contribucions del sòl i de la interacció sòl-tall puga ser important en la resposta total de retrodispersió. Així doncs, aquest tipus de vegetació es pot modelar com un volum orientat sobre terra (Oriented Volume over Ground surface-OVoG-).

En aquest context, es presenta aquesta tesi amb la qual es pretén abordar l'estimació de paràmetres biofísics de cultius agrícoles mitjançant l'ús d'interferometria polarimètrica SAR 
així com models electromagnètics simples, com el RVoG i el OVoG.

En primer lloc, s'analitza la capacitat del model de volum aleatori sobre terra per a l'estimació de l'altura dels cultius, la topografia del sòl i el coeficient d'extinció diferencial amb la utilització de mesures PolInSAR. Les nostres observacions estan obtingudes mitjançant l'anàlisi de la localització dels punts de coherència complexa al plànol complexe, com originalment ja van indicar Cloude i Papathanassiou [PCOl] per al cas d'extracció de paràmetres de zones forestals.

L'avaluació de la validesa d'aquest model quan s'aplica sobre una escena vegetal que més bé respon a un volum orientat, com el panís i l'arròs, revelarà una nova regió de les coherències complexes observades, la qual cosa concerneix la segona part de la tesi. En particular, el problema d'inversió es tractarà en una primera etapa mitjançant l'estudi de la correspondència entre la regió de coherències ocupada per les coherències experimentals $i$ la posició de les coherències proporcionades pel model de volum orientat sobre plànol de terra $(\mathrm{OVoG})$. Cal tenir en compte que l'efecte de la superfície de terra per al volum orientat, el qual no ha estat prèviament considerat en la literatura, ha estat introduit en aquest estudi. Així, es discutirà l'aplicabilitat d'aquest model analitzant la influència dels paràmetres d'interès de l'escena, com són l'altura de la planta, la topografia del sòl, els coeficients d'extinció, el coeficient d'extinció diferencial, així com els paràmetres del sistema, és a dir, la freqüència, la línia de base, etc. Igualment, es compararan les estimacions obtingudes tant pel model RVoG com pel OVoG per tal d'analitzar la viabilitat d'ambdós models per a l'extracció paramètrica en cultius.

Com es mostrarà després, el paper que juga el coeficient d'extinció així com el significat físic que presenta estan encara per clarificar. Aquest paràmetre apareix en el modelatge electromagnètic directe quan es considera l'atenuació de l'ona propagada. Així doncs, l'efecte que produeix pot ser directament interpretat com a pèrdues de propagació per al càlcul de la magnitud (o potència) del camp dispersat. No obstant això, la influència que té als observables PolInSAR, és a dir, en la correlació creuada normalitzada per a cada canal de polarització, no és evident. De fet, es veurà amb simulacions del model OVoG com grans variacions d'extinció es corresponen amb insignificants canvis en la posició de les coherències complexes i, per tant, aquesta manca de sensibilitat n'impossibilita l'estimació mitjançant el procés d'inversió basat en un mètode geomètric [CP03] utilitzant els models OVoG o RVoG.

A més a més, s'ha de tenir en compte que el problema d'inversió presenta una gran no linealitat, raó per la qual s'hauran de proposar mètodes d'inversió complementaris per tal de donar-li solució. Per una banda, es proposa un procediment híbrid, basat en dues etapes, una geomètrica i una altra numèrica. Per altra banda, una configuració basada en l'ús de dues línies de base s'utilitzarà per tal d'augmentar la dimensió de l'espai d'observació.

Finalment, es farà una anàlisi alternativa de la resposta electromagnètica d'una mostra de panís mitjançant perfils en rang de retrodispersió en funció de la penetració del senyal en la vegetació. Són dos els objectius d'aquesta part del treball de tesi. Per una bada, s'estudia un mètode alternatiu d'estimació del coeficient d'extinció diferencial analitzant els perfils en rang de retrodispersió del cultiu en els canals de polarització corresponents a les bases lexicogràfica i de Pauli. Per altra banda, la variació en funció de la profunditat de penetració 
dels paràmetres polarimètrics segons la descomposició de Cloude-Pottier [CP96, CP97] se utilitzarà per tal d'obtenir informació complementària sobre els processos de dispersió que apareixen al llarg del volum. Les conclusions que s'obtindran d'aquestes observacions permetran proporcionar estimacions del coeficient d'extinció diferencial així com aprofundir en el coneixement de la caracterització dels cultius en termes de la resposta polarimètrica que presenten.

A mode de resum, els objectius marcats per aquesta tesi són:

- Estudiar i analitzar l'aplicabilitat del model RVoG per a l'estimació de paràmetres biofísics de cultius agrícoles. Es particularitzarà en dos tipus de cultius: panís i arròs.

- Desenvolupar i verificar un algoritme d'inversió per a cultius, els quals estan modelats sota les asssumpcions del model de volum orientat sobre terra (OVoG). Com a pas previ, és necessari considerar la influència del sòl sobre el volum orientat, la qual cosa no ha estat tractada en la literatura amb anterioritat. S'obtindrà una expressió formal per a la correlació creuada polarimètrica per aquest tipus d'escenes.

- Com es podrà observar, el problema d'inversió presenta una indeterminació en el cas del model OVoG. Per tant, s'han d'investigar estratègies alternatives per a l'estimació paramètrica completa. Aquestes estratègies es basaran bé en un mètode híbrid, és a dir, geomètric i numèric, bé en un mètode numèric únicament utilitzant una configuració amb dues línies de base.

- Estudiar i analitzar la resposta electromagnètica de mostres de cultius mitjançant perfils en rang de potència retrodispersada així com una anàlisi polarimètrica, en funció de la penetració de l'ona dins del volum. Amb açò és possible extraure informació sobre l'estructura vertical dels cultius.

En la següent secció es proporciona un resum global dels resultats obtinguts, així com la discussió sobre els mateixos i les conclusions finals del treball de tesi.

\section{Discussió dels resultats i conclusions finals}

Com ja s'ha esmentat abans, el treball desenvolupat durant la tesi està dirigit a l'estimació de cultius agrícoles mitjançant les tècniques PolInSAR, amb especial atenció als cultius de panís i arròs. La validació i verificació dels mètodes d'inversió paramètrica així com dels models desenvolupats en aquest treball ha estat recolzada en les mesures SAR de banda ampla i totalment polarimètriques dutes a terme al European Microwave Signature Laboratory (EMSL), Ispra, Itàlia. És per això que cal tenir en compte que les condicions controlades que s'imposen en un laboratori a l'hora de fer mesures limiten una generalització àmplia de les observacions i conclusions d'aquest treball. No obstant això, resulta evident que aquestes 
conclusions constitueixen una important font d'informació sobre la caracterització de la resposta radar dels cultius, i cal tenir-la en compte per a la implementació fiable d'algoritmes d'inversió paramètrica de vegetació.

A continuació, es presenten els resultats del treball de tesi, la discussió d'aquests resultats i les conclusions finals.

En una primera etapa, s'ha investigat l'aplicabilitat del model RVoG a l'estimació de paràmetres biofísics per a dos tipus de cultius, el panís i l'arròs. S'ha aplicat un algoritme d'inversió ja existent basat en un procediment geomètric i en el model de dues capes per estimar l'altura de les plantes, la topografia del sòl i el coeficient d'extinció. D'aquesta anàlisi, s'ha adaptat el procediment d'inversió per a cultius, considerant la dependència de l'atenuació de la polarització. Com una primera contribució original d'aquesta tesi, la influència de la contribució del terra en un volum orientat, no tractada prèviament en la literatura, ha estat considerada i una expressió formal per a la correlació creuada polarimètrica s'ha obtingut. Quant als resultats d'inversió s'observa que, si es mantenen certes condicions de l'interferòmetre, els algoritmes d'inversió tant per al model RVoG com per al model OVoG, proporcionen raonables resultats, amb precisions en el cas pitjor del 11\%, per a diverses configuracions de frequiències i línies de base. Cal dir però, que ambdós models mostren una manca de sensibilitat al coeficient d'extinció i, per tant, s'impossibilita l'estimació d'aquest paràmetre mitjançant el mètode geomètric.

Les condicions anomenades abans per a una estimació correcta de la topografia i l'altura del volum es poden assolir mantenint el producte $k_{z} \cdot h_{v}$ dins d'uns límits determinats. Per una banda, el límit superior està fixat per la decorrelació volumètrica induïda per la capa de vegetació. En aquest cas, s'observa que l'algoritme proporciona resultats correctes per a valors de coherència per damunt de 0.3 . Per altra banda, el límit inferior assegura suficient sensibilitat de l'interferòmetre a l'estructura vertical del blanc. Assumint una altura constant i homogeneïtat en el volum, aquests límits es poden controlar mitjançant valors apropiats de frequiència i línia de base.

Les característiques físiques dels cultius introdueixen altres diferències en la resposta radar en comparació a l'obtinguda en zones forestals. Aquestes particularitats s'expliquen observant la distribució de les coherències al plànol complex. Atès que la morfologia d'aquestes plantes es considera com un volum homogeni de curta altura, la resposta de retrodispersió es correspon amb contribucions que venen de la mostra de vegetació completa, és a dir, tant la capa superior com inferior estan igualment presents. Aquest fet està en contraposició amb el que es dóna en el cas dels boscos, on la resposta radar està dominada per la capa superior del volum on es situen les branques i fulles dels arbres. Aquest comportament provoca algunes diferències en la distribució de les coherències complexes associades amb els vectors del blanc en la base de Pauli. En primer lloc, s'observa que la coherència associada amb el canal HV es posiciona en una zona intermitja al llarg de la distribució lineal de coherències. Açò produeix que els canals crosspolars ja no puguen ser utilitzats en el procediment d'inversió per tal d'identificar la capa superior del volum de vegetació, com passa per als boscos. En realitat, el canal $\mathrm{HH}+\mathrm{VV}$, el qual representa la contribució de scattering directe, es correspon amb la capa superior del volum. En segon lloc, la coherència associada amb la contribució de 
scattering tipus diedre, HH-VV, és la que més a prop està del terra, indicant una contribució important de la interacció sòl-tall.

En aquest punt s'ha de puntualitzar que les observacions anteriors descriuen la resposta electromagnètica dels cultius de panís, però no poden ser directament aplicades al cas de l'arròs com a consequiència de la curta altura d'aquest tipus de planta. Aquest volum reduït fa que la interacció superfície-tall, amb el sòl cobert d'aigua, domine la resposta de retrodispersió per damunt de la contribució baixa que aporta el volum. Conseqüentment, les coherències complexes estan agrupades en una xicoteta regió a prop del cercle unitat. Aquesta propietat possibilita una estimació molt precisa de l'altura topogràfica. No obstant això, la inversió mitjançant l'ajust de línia no és possible en les bandes $\mathrm{S}$ o $\mathrm{C}$, ja que el número d'ona vertical és molt baix per tal de proporcionar suficient sensibilitat a l'estructura vertical de la planta d'arròs. Així doncs, és necessari un $k_{z}$ més alt que en el cas del panís per a obtenir resultats acceptables en la inversió. S'ha pogut observar que a partir de $7 \mathrm{GHz}$ i $k_{z}=3.64$ s'obtenen estimacions correctes tant per a l'altura de la planta com per a la topografia.

La capacitat d'inversió de l'algoritme proposat per al panís i l'arròs ha estat també posada a prova amb dades parcialment polarimètriques. Amb les dues mostres de vegetació s'observa que s'obtenen resultats correctes quan s'utilitzen les coherències corresponents als tipus de scattering directe i diedre, és a dir, HH+VV i HH-VV. Açò suposa un important resultat que s'ha de tenir en compte en la definició de futures missions SAR amb capacitat per a la combinació cohererent dels canals copolars, com PALSAR/ALOS, Radarsat-2 i TanDEM$\mathrm{X}$. A més a més, cal que dir que aquest resultat emfatitza el potencial de la polarimetria compacta (compact polarimetry), la qual s'ha mostrat com una eina efectiva per a evitar les limitacions tècniques respecte la reducció de cobertura i l'amplària de banda del sistema, que la transmissió simultània dels dos canals copolars implica.

A la Taula l es resumeixen les capacitats d'estimació d'aquesta tècnica i es comparen amb les estratègies alternatives que s'han desenvolupat també en aquesta tesi i que es discuteixen després.

Respecte els requeriments del número d'ona vertical que s'ha esmentat abans, es pot afirmar que els valors de línia de base per a un sistema InSAR no són restrictius. Per exemple, amb el sensor ASAR de la missió ENVISAT (amb un satèl.lit a una altura sobre els $800 \mathrm{~km}$, un angle d'incidència de $23^{\circ}$ i una frequiència central de $5.3 \mathrm{GHz}$ ), línies de base des de $150 \mathrm{a}$ $1000 \mathrm{~m}$ proporcionen valors de $k_{z}$ entre $0.1 \mathrm{i} 0.7$, els quals asseguren una baixa decorrelació volumètrica alhora que suficient sensibilitat a l'estructura vertical del blanc. No obstant això, també s'ha de considerar l'efecte del desplaçament del número d'ona, el qual pot ser important en el cas particular del sensor ASAR, ja que l'amplària de banda del senyal té un valor prou reduït de $18 \mathrm{MHz}$. Així doncs, la línia de base crítica és $1253 \mathrm{~m}$ i la línia de base màxima des del punt de vista pràctic assumint la meitat de l'espectre disponible es pot situar sobre els $600 \mathrm{~m}$, sent 0.4 el corresponent valor del número d'ona vertical. Aquests valors corresponen al cas monostàtic. No obstant això, per al cas bistàtic el desplaçament espectral és la meitat i, per tant, la línia de base crítica és el doble, és a dir, $2500 \mathrm{~m}$.

En el cas del TerraSAR-X (polarització dual en mode operatiu i quad-pol com a mode experimental), assumint una línia de base de $300 \mathrm{~m}$, el valor de $k_{z}$ va des de 0.24 fins a 0.58 
quan es prenen els angles d'incidència màxim i mínim per al mode stripmap, els quals són $45^{\circ}$ i $22^{\circ}$, respectivament. L'amplària de banda nominal en aquest sistema és de $150 \mathrm{MHz}$, encara que es diposa de fins a $300 \mathrm{MHz}$ en mode experimental. Per altra banda, el sistema Radarsat-2 utilitzarà una amplària de banda de $100 \mathrm{MHz}$. Aquests dos sistemes podran operar en el futur en missions tàndem (TanDEM-X, ja aprovat, i Radarsat-3) amb l'objectiu de proporcionar mesures interferomètriques single-pass de la superfície de la Terra, la qual cosa suposa un avantatge ja que s'evita la influència de la decorrelació temporal que caracteritza les mesures repeat-pass.

Assumint com a punt d'inici el cas particular de la mostra de panís, s'ha generalitzat la discussió sobre els requeriments de la geometria de la línia de base. Considerant una incidència de $45^{\circ}$ i una altura de l'òrbita de $550 \mathrm{Km}$, s'ha calculat el quocient entre la línia de base normal i la longitud d'ona en funció de l'altura del volum, així com la línia de base normal en funció de la longitud d'ona per a una altura determinada. De l'anàlisi d'aquestes funcions s'observa que la condició de mínima coherència (decorrelació volumètrica) no és gens restrictiva en absolut ja que correspon a valors de la línia de base molt alts o fins i tot a valors que no són realistes. Per altra banda, el límit inferior, que s'associa a la sensibilitat del volum, restringeix la mínima línia de base a $1700 \mathrm{~m}$ per a la banda $\mathrm{S}, 1300 \mathrm{~m}$ per a la banda $\mathrm{C}$ i uns $700 \mathrm{~m}$ per a la banda X. A més, s'ha de dir que la línia de base crítica no és un factor que limite el sistema sempre que es dispose d'una amplària de banda major a $40 \mathrm{MHz}$. Considerant aquesta amplada de banda i els mateixos paràmetres, els valors corresponents de la línia de base crítica per a les bandes $\mathrm{S}, \mathrm{C}$ i X i un interferòmetre monostàtic són valors molt alts (12400, 5870 i 3240 m, respectivament). Açò resulta més evident en el cas bistàtic ja que el desplaçament espectral és la meitat del cas monostàtic i, per tant, la línia de base crítica és el doble.

En qualsevol cas, cal tenir en compte que fins i tot per a línies de base menors que la crítica hi poden aparèixer problemes depenent de l'aplicació. Per exemple, el filtratge espectral en rang s'aplica molt sovint per evitar problemes per desplaçament del número d'ona, encara que això empitjora la resolució en rang i, per tant, disminueix la quantitat de looks disponible, la qual cosa podria ser una important limitació per a la monitorització de cultius en àrees d'extensió reduïda.

Aquest resultats proporcionen informació addicional sobre els requeriments del sistema interferomètric, però cal tenir en compte que la generalització no és directa ja que estan basats en observacions experimentals sobre una mostra concreta de panís amb una altura de $1.8 \mathrm{~m}$.

En aquesta tesi també s'ha treballat amb les quiestions relatives al modelatge electromagnètic dels cultius. Així, també constitueix una aportació original d'aquest treball el desenvolupament matemàtic de les expressions de la funció de correlació creuada polarimètrica per al model de volum orientat sobre terra, per als modes d'adquisició monostàtic i bistàtic, també anomenats alternate-transmit (o ping-pong) i single-transmit, respectivament. A més a més, les diferències que sorgeixen entre els dos modes d'operació i les implicacions a l'hora d'utilitzar el model per a inversió paramètrica també s'han discutit. El fet més important és que apareix un terme de decorrelació volumètrica addicional que afecta les mesures en el mode bistàtic i, com a conseqüència d'això, la regió visible de coherències complexes 
es desplaça cap a l'origen del plànol complex. Es pot observar que els canals crosspolars no mostren la mateixa posició, excepte per a una contribució del sòl nul.la, a causa de les diferents extincions del volum i de la configuració bistàtica. A més a més, les línies crosspolars no estan contingudes dins de la regió definida per les línies de coherència dels canals copolars, contrariàment al cas monostàtic. Finalment, és molt important el fet que la fase de les coherències dels canals crosspolars amb el quocient sòl-terra infinit (la resposta està dominada pel terra i la del volum és insignificant) no es correspon amb la fase topogràfica. Aquest resultat pot resultar molt important per a la definició de futurs sistemes single-pass, com la missió TanDEM-X, així com els algoritmes d'inversió associats.

Les limitacions del model directe per al OVoG han estat també objecte d'investigació. A causa de l'orientació vertical de les plantes, la polarització vertical resulta més fortament atenuada que la polarització horitzontal. Aquests dos estats de polarització s'anomenen autopolaritzacions (eigenpolarizations). En la representació al plànol complex de les coherències del model OVoG, les autopolaritzacions s'associen a dues línies les quals defineixen els límits de la regió possible de coherències. No obstant això, les coherències experimentals en la base lineal no estan ordenades com descriu el model, ja que la coherència crosspolar s'associa a una extinció menor que les copolars. Aquest comportament està present en les bandes $\mathrm{S}, \mathrm{C}$ i X, per tant, tot indica que es correspon amb una limitació en el model directe. Addicionalment, aquesta idea està recolzada pel fet que la correspondència entre la regió visible de coherències per al model OVoG i les mesures és únicament aproximada.

Aquestes discrepàncies entre el model teòric i les mesures apareix com a conseqüència de les assumpcions fetes en el modelatge electromagnètic. En primer lloc, la capa de vegetació es considera homogènia. No obstant, per a la mostra de panís, per exemple, seria molt més correcte modelar el volum en dues capes. La capa inferior estaria formada pels talls orientats verticalment, mentre que la capa superior s'aproxima més a un volum aleatori. En segon lloc, la interacció entre els elements de la vegetació soles s'ha considerat parcialment mitjançant un modelatge estadístic del camp retrodispersat total amb una aproximació de scattering de primer ordre. Com s'ha demostrat a la literatura, aquesta suposició pot afectar de forma important la resposta electromagnètica dels cultius, per exemple, subestimant el nivell del canal crosspolar. Conseqüentment, un model directe més complet seria necessari per tal de calibrar de forma més exacta l'efecte del coeficient d'extinció i el quocient entre potència rebuda del sòl i la del volum.

Els dos models amb els quals s'ha treballat, RVoG i OVoG, estableixen relacions directes entre els observables proporcionats pel sistema radar i els paràmetres de vegetació. No obstant això, aquestes relacions es caracteritzen per una gran no linealitat, raó per la qual els mètodes d'inversió numèrica presenten una gran variació de les estimacions quan s'apliquen procediments iteratius. A més a més, el problema es converteix en indeterminat per al model OVoG ja que existeixen sis observables, és a dir, les parts reals i imaginàries dels tres canals polarimètrics en la base lineal, i set incògnites, les quals són l'altura del volum, la topografia del sòl, les extincions vertical i horitzontal, i el quocient sòl-volum per als tres canals de polarització. Per tal de superar aquest problema, s'han proposat i verificat tres estratègies diferents per a l'estimació paramètrica. 
La primera estratègia consisteix, com ja s'ha explicat anteriorment, en aplicar un procediment geomètric ja existent basat en un ajust lineal de les coherències experimentals, similarment a com es va fer originalment en el cas de les zones forestals. Aleshores, l'algoritme d'inversió proporciona estimacions de la posició vertical del sòl i l'altura del cultiu, però no del coeficient d'extinció, el qual s'assumeix dins d'un cert interval de valors.

La segona estratègia, la qual es una aportació original d'aquesta tesi, és un mètode híbrid format per una etapa geomètrica i una numèrica. La primera etapa es correspon amb l'ajust d'una línia a les coherències experimentals, com ja s'ha descrit, la qual cosa proporciona una estimació de la fase topogràfica. La segona etapa, la qual utilitza la fase topogràfica estimada, és un algoritme genètic que dóna les solucions de la resta de paràmetres. Els resultats d'aquest mètode depenen molt dels valors inicials d'entrada al procediment iteratiu i s'han de fer una gran quantitat de proves. Cal dir però, que estimacions raonables s'obtenen per a diverses configuracions de freqüències i línies de base (vegeu la Taula 1).

Finalment, s'ha desenvolupat un tercer procediment d'inversió, que també constitueix part de les noves contribucions que aporta la tesi. En aquest cas, s'ha utilitzat una configuració de línia de base dual per tal d'augmentar l'espai d'observació. Així, dos valors diferents de línia de base produeixen un total de dotze dades reals d'entrada amb les quals s'han d'estimar set paràmetres del model. Els resultats per a la mostra de panís són similars als obtinguts amb el mètode geomètric i el mètode híbrid. Per contra, les estimacions per a la mostra d'arròs no són satisfactòries, ja que s'aprecia una gran desviació típica en els resultats, excepte per a la fase topogràfica a causa de la presència de una elevada contribució de la interacció sòl-tall en algun dels canals de polarització.

Les conclusions sobre les capacitats d'inversió dels tres algoritmes presentats es resumeixen en la Taula 1, on es mostren les precisions obtingudes per a l'altura de les mostres de panís i arròs així com la topografia del sòl. Aquests valors representen el cas pitjor, però cal dir que es poden aconseguir precisions de fins al 5-6\% per a certes configuracions en el cas del panís i valors més baixos del $11 \%$ per al cas de l'arròs assumint una desviació típica major. En general, es pot observar que la precisió és similar per al tres procediments, excepte per a l'altura de la mostra d'arròs amb el mètode de línia de base dual, on s'obtenen errors d'estimació molt elevats. Conseqüentment, si dirigim l'atenció a l'estimació de l'altura de la vegetació i la topografia, aleshores es pot dir que el mètode geomètric seria preferible sobre la resta, a causa de la simplicitat d'implementació i el baix cost computacional que presenta si el comparem amb els mètodes híbrids.

Un altre mètode que s'ha utilitzat en aquesta tesi per estudiar l'estructura vertical dels cultius ha estat l'anàlisi dels perfils de potència retrodispersada en rang i una anàlisi dels paràmetres polarimètrics en funció de la penetració de l'ona electromagnètica dins del volum. Aquesta part del treball, la qual requereix mesures radar de banda ampla per tal d'obtenir uns perfils d'alta resolució, s'ha particularitzat en el cas de la mostra de panís.

Per una banda, s'observa que l'evolució de la diferència de la secció recta radar entre els canals HH i VV mostren una tendència a l'increment en funció de la dimensió slant-range. Aleshores, si s'assumeix que el medi és homogeni, la pendent d'aquest observable és directament proporcional al coeficient d'extinció diferencial. A partir d'aquesta observació 


\begin{tabular}{|c|c|c|c|c|}
\hline PRECISIÓ & \multicolumn{2}{|c|}{ Panís } & \multicolumn{2}{c|}{ Arròs } \\
\hline & $h_{v}$ & $z_{0}$ & $h_{v}$ & $z_{0}$ \\
\hline Geomètric & $11 \%$ & $11 \%$ & $11-13 \%$ & $4 \%$ \\
\hline Híbrid & $10 \%$ & $15 \%$ & $11 \%$ & $4 \%$ \\
\hline Dual-baseline & $9 \%$ & $8 \%$ & $>30 \%$ & $4 \%$ \\
\hline
\end{tabular}

Table 1: Comparació de l'error d'estimació obtingut per cada procediment d'inversió per a l'altura de la planta i la topografia del sòl.

s'ha definit un procediment d'estimació per aquest paràmetre des de 2 fins a $8 \mathrm{GHz}$. Els resultats que s'han obtingut s'han comparat amb els únics experiments que hem trobat per mesurar aquest paràmetre en un cultiu de panís [UTS87]. Aquestes mesures es van fer per a $1.62 \mathrm{GHz}$ i $4.75 \mathrm{GHz}$. Per al primer cas, l'extinció vertical és de $2 \pm 0.75 \mathrm{~dB} / \mathrm{m}$, mentre que l'horitzontal de $0.3 \pm 0.2 \mathrm{~dB} / \mathrm{m}$. Per a $4.75 \mathrm{GHz}$, l'extinció vertical és de $0.9 \pm 0.8$ $\mathrm{dB} / \mathrm{m}$, mentre que per a l'horitzontal és $0.7 \pm 0.5 \mathrm{~dB} / \mathrm{m}$. Els resultats derivats del procediment d'inversió proposat estan al voltant d'aquests valors però, no obstant això, cal tenir en compte que la validesa d'aquest mètode està limitada per les dimensions finites de la mostra de panís així com la forma quadrada de la plataforma. En qualsevol cas, es pot dir que els resultats que se'n deriven es podrien utilitzar com a informació complementària en el desenvolupament d'algoritmes d'inversió per a volums orientats.

Per altra banda, l'anàlisi dels paràmetres polarimètrics que s'obtenen quan s'aplica la descomposició del blanc (target decomposition) ha revelat aspectes importants sobre els processos de scattering en la planta de panís. L'extinció diferencial està associada amb una contribució global de scattering de tipus dipol dins del volum, ja que la polarització vertical s'atenua molt més que la polarització horitzontal. Per tant, el valor mitjà del paràmetre $\alpha$ varia linealment des de zero, corresponent al scattering directe d'una superfície, fins a $45^{\circ}$, corresponent al scattering tipus dipol, segons l'ona es propaga pel volum. A més a més, s'han observat valors alts d'entropia i valors baixos d'anisotropia a tot el volum de vegetació per a les bandes S, C i X, la qual cosa indica la presència de tres mecanismes de scattering. Cal dir però, que l'alta entropia observada fa perdre validesa a la interpretació del scattering tipus dipol com a contribució dominant, ja que alts valors d'entropia estan sempre associats amb valors de $\alpha$ al voltant de $45^{\circ}$.

Finalment, un altre procediment d'estimació del coeficient d'extinció diferencial ha sigut investigat. En aquest cas, s'ha relacionat la variació del valor mitjà de $\alpha$ en funció del camí de propagació amb l'extinció diferencial, però s'ha comprovat que no és possible una inversió correcta ja que aquest paràmetre es satura a partir de $1 \mathrm{~dB} / \mathrm{m}$ aproximadament, el qual és un valor baix d'extinció.

Una vegada s'han descrit els resultats més importants i les conclusions del treball, es comenten les actuals i futures línies d'investigació.

En primer lloc, és necessari analitzar la capacitat d'inversió dels mètodes proposats en aque- 
sta tesi amb dades reals adquirides fora del laboratori. En principi, les dades obtingudes des de sistemes aerotransportats estan afectades per dues limitacions inherents a un sistema InSAR, com són els efectes de decorrelació per línia de base i decorrelació temporal. El primer pot ser eliminat mitjançant filtratge espectral, encara que això limita el nombre de mostres independents. De fet, açò limita la màxima línia de base $\mathrm{i}$, per tant, el producte $k_{z} \cdot h_{v}$ a cert valor. El segon efecte no pot ser eliminat i està sempre present en sistemes repeatpass, de manera que redueix la capacitat d'estimació dels algoritmes que utilitzen aquest tipus de dades. És per aquesta raó que resulta fonalment diposar de mesures totalment polarimètriques de banda ampla adquirides amb un sistema interferomètric single-pass.

En segon lloc, s'haurien de considerar altres models electromagnètics i/o introduir millores en els actuals, així com en els procediments d'inversió associats.

Sobre la qüestió del modelatge electromagnètic, la particular morfologia d'alguns tipus de cultius, com el panís i l'arròs, així com les observacions que es deriven d'aquesta tesi emfatitzen la necessitat d'un model híbrid, el qual ja va ser introduït i discutit en [UMF86], on la vegetació es modela com un volum de dues capes. La capa superior correspondria a un volum orientat, ja que està format per fulles (per a la planta de panís) i grans i talls (per a la planta d'arròs) corbats cap a baix i orientats de forma aleatòria. Per altra banda, la capa inferior per ambdós tipus de vegetació estaria formada principalment per talls verticals. L'addició de l'efecte del sòl proporcionaria, en principi, una descripció més detallada de la planta. En qualsevol cas, apareixeria un nou inconvenient en el procés d'inversió ja que s'haurien de considerar dues incògnites addicionals, és a dir, l'altura de la capa aleatòria i el coeficient d'extinció escalar associat.

La contribució del scattering múltiple és un altre factor que s'hauria d'investigar. S'ha demostrat en treballs previs que els models de primer ordre subestimen la component crosspolar retrodispersada i que el teorema del Forward Scattering no és apropiat per a modelar els cultius de blat de moro, ja que sobreestima l'atenuació de la polarització vertical. Per exemple, en $[\mathrm{BQM}+03]$ les imatges radar d'alta resolució que s'obtenen il-lustren la presència de contribucions de scattering de segon ordre. Des del punt de vista dels observables PolIn$\mathrm{SAR}$, la influència del scattering multiple en la coherència complexa no es produeix per la RCS, ja que les variacions d'intensitat queden normalitzades per la pròpia definició de la coherència interferomètrica, sinó pel perfil o distribució vertical dels valors de la RCS, és a dir, la variació dels centres de fase.

Els requeriments del sistema interferomètric per aplicacions de monitorització de cultius és una altra línia amb la qual s'ha d'aprofundir, amb l'objectiu d'optimitzar el disseny del sistema prenent com a paràmetre fonamental el quocient entre la línia de base i la longitud d'ona.

Per altra banda, el potencial de la funció de correlació de freqüència (FCF) o $\Delta k$-radar aplicada a la inversió paramètrica d'un volum orientat sobre terra està sent actualment objecte d'investigació. Aquesta funció es pot veure de forma equivalent a un sistema multi-baseline però substituint la diversitat en l'angle d'incidència per la diversitat freqüencial. En els estudis que estem duent a terme, el procés d'inversió s'aplica fent ús no només del valor absolut de la funció, sinó també de la informació de fase de la FCF, utilitzant tota la informació 
polarimètrica completa proporcionada en la base lineal, ja que s'assumeix que les autopolaritzacions es corresponen als canals horitzontal i vertical. Les primeres conclusions mostren de nou que cal desenvolupar un model directe més complet per tal de descriure millor la dependència de la coherència normalitzada respecte els coeficients d'extinció $i$ el quocient sòl-volum. És important tenir en compte que la funció FCF presenta dos inconvenients. Per una banda, la capacitat per a separar els efectes de la superfície i el volum és limitada. Per l'altra banda, aquesta funció mostra gran dependència del sistema radiant, la qual cosa complica que es puga aillar la resposta del blanc de la del sistema. Conseqüentment, l'aplicació d'aquesta tècnica es redueix a l'estudi i caracterització de determinats tipus de blancs en condicions controlades de laboratori.

Finalment, cal obtenir més informació sobre els paràmetres biofísics que són útils per als usuaris finals, així com conèixer la precisió que es requereix en l'estimació. En l'última part d'aquesta tesi, hem estat en contacte amb potencials usuaris finals i els seus comentaris ens han servit per a orientar la investigació futura sobre l'estimació paramètrica amb PollnSAR. Respecte l'altura de les plantes, sembla ser que la utilitat que té per sí mateix per a la monitorització de cultius és limitada. Contràriament al cas de les aplicacions en boscos, on l'altura està directament relacionada amb la biomassa mitjançant les equacions al-lomètriques, no resulta evident assimilar l'altura del cultiu amb els paràmetres agronòmics, com són el LAI (Leaf Area Index) o el fAPAR (fraction of Absorbed Photosynthetically Active Radiation), els quals informen sobre la quantitat d'energia que la planta captura del Sol. No obstant això, la biomassa és també un paràmetre important en la monitorització de cultius i, per tant, seria clau poder investigar si és possible relacionar-la amb l'altura del cultiu i la densitat de plantes.

En qualsevol cas, l'altura dels cultius pot resultar important en altres situacions. Per exemple, es conegut que els cultius d'arròs a Sevilla (Espanya) pateixen els efectes del vent de Llevant. Quan bufa aquest vent, els talls d'arròs es tomben i les parts superiors entren en contacte amb l'aigua, raó per la qual acaben podrint-se. En aquest cas, l'estimació de l'altura es podria utilitzar per tal d'identificar aquelles zones que han estat afectades per aquest problema. Una utilitat addicional de les estimacions de l'altura consisteix a utilitzar-les com a paràmetres auxiliars en altres tècniques d'inversió diferents. Els valors precisos d'altura obtinguts mitjançant PolInSAR es poden introduir en un model de transferència radiativa per tal d'invertir altres parèmetres més fàcilment, com la humitat del sòl i la rugositat.

Quant a la precisió requerida en l'estimació de l'altura dels cultius, s'ha d'assenyalar que és molt complicat indicar un valor determinat, ja que, com es comprova en les mesures de camp (ground-truth), existeix una distribució d'altures fins i tot dins del mateix pixel. Per exemple, l'altura en camps de cultiu de blat de moro pot oscil.lar entre 70 i $80 \mathrm{~cm}$. Per tant, en aquest cas es pot afirmar que un sistema amb un precisió sobre $12-14 \%$ proporcionaria un seguiment correcte del corresponent perfil d'altures.

Un altre paràmetre que s'ha de continuar investigant és el coeficient d'extinció. És conegut que la importància d'aquest paràmetre radica en la relació que té, a través de la permitivitat, amb el contingut d'aigua de la planta. No obstant això, des del punt de vista ecològic, l'interès està centrat en el que s'anomena potencial hídric de la planta, el qual és funció del 
contingut d'aigua. Aquest paràmetre és molt útil per aplicacions com l'optimització del rec dels cultius, la predicció de les temporades de sequera i d'incendis, així com la detecció de patologies de la planta.

Per acabar, es pot afirmar que els principals objectius d'aquesta tesi s'han aconseguit, la qual cosa s'ha evidenciat amb la discussió en conferències internacionals i la publicació en revistes internacionals dels resultats obtinguts en aquesta investigació. Cal dir també que una part d'aquest treball va ser guardonada amb el First Student Paper Award al 5è European Conference on Synthetic Aperture Radar (EUSAR), celebrat a Ulm (Alemànya) a l'any 2004. 


\section{Universitat d'Alacant} Universidad de Alicante

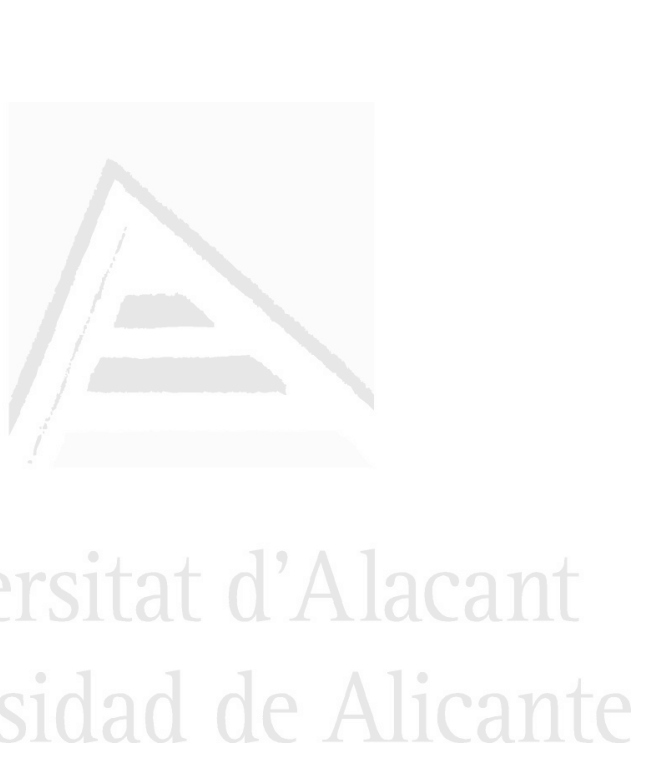




\section{Contents}

1 Introduction and Scope of this Thesis 1

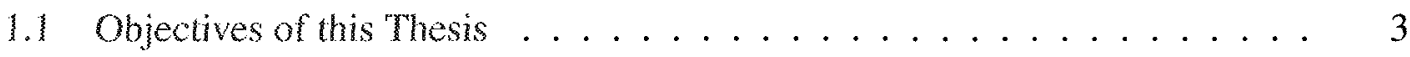

1.2 Organization of this thesis $\ldots \ldots \ldots \ldots$

2 State of the Art 9

2.1 Polarimetry ......................... 11

2.2 SAR Interferometry . . . . . . . . . . . . . . . . 16

2.3 Polarimetric SAR Interferometry . . . . . . . . . . . . . . . . 17

3 Theory of Polarimetric SAR Interferometry 23

3.1 Synthetic Aperture Radar . . . . . . . . . . . . . . . . 23

3.1.1 Fundamentals on SAR Imaging . . . . . . . . . . 23

3.1 .2 SAR data statistics . . . . . . . . . . . 26

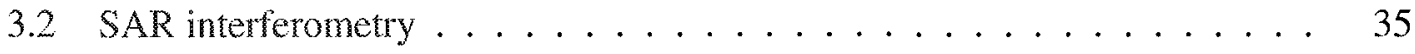

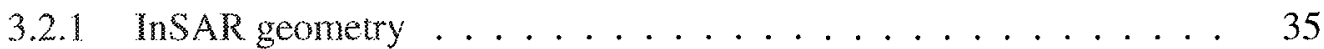

3.2 .2 The interferometric phase $\ldots \ldots \ldots 36$

3.2 .3 The interferometric coherence ............ 38

3.2.3.1 Sources of coherence degradation . . . . . . . . 39

3.3 Radar Polarimetry . . . . . . . . . . . . . . . . . 42

3.3.1 Plane wave polarization ................ 42 
3.3.1.1 Change of polarization basis .......... 44

3.3.1.2 Partially polarized waves $\ldots \ldots \ldots \ldots \ldots$

3.3 .2 The scattering matrix $\ldots \ldots \ldots . \ldots . \ldots 46$

3.3.2.1 Coordinate system conventions .......... 47

3.3.2.2 Vectorization of the scattering matrix ........ 48

3.3.3 The polarimetric covariance and coherency matrices ...... 49

3.3.4 Mueller and Kennaugh matrices . . . . . . . . . . . . . . . 50

3.3.5 Target decomposition theory: eigenvector decomposition . . . . . 52

3.3.5.1 Eigenvector decomposition of the coherency matrix . . . 53

3.4 Theory of Polarimetric SAR Interferometry . . . . . . . . . 55

3.4.1 Vector Interferometry . . . . . . . . . . . . . 55

3.4 .2 Coherence Optimization ................. 56

4 Direct Electromagnetic Models of Agricultural Crops 59

4.1 Introduction . . . . . . . . . . . . . . . . . 59

4.2 Full-wave scattering model . . . . . . . . . . . . 60

4.3 Simple models: RVoG and OVoG . . . . . . . . . . . . . . . . 64

4.3.1 Random volume over ground surtace (RVoG) . . . . . . . . 67

4.3 .2 Oriented volume over ground surface $($ OVoG $) \ldots \ldots 78$

4.3.2.1 Effect of the bistatic angle . . . . . . . . . 92

5 Retrieval of Biophysical Parameters by Using PolnSAR and Simple Models 95

5.1 RVoG and OVoG Models ...................... 97

5.2 Inversion Strategies . . . . . . . . . . . . . . . . . 101

5.2.1 Analysis of the Coherence Loci for an Oriented Volume over Ground 101

5.2.1.1 Comparison With Experimental Data . . . . . . . 103

5.2 .2 Geometrical Approach . . . . . . . . . . . . . . . 107

5.2 .3 Numerical Approach . . . . . . . . . . . . . . 111

5.2 .4 Hybrid Approach . . . . . . . . . . . . . . . . . . 112

xxii

Tesis doctoral de la Universidad de Alicante. Tesi doctoral de la Universitat d'Alacant. 2007. 
5.3 Experimental Results . . . . . . . . . . . . . . . . 113

5.3 .1 Indoor Measurements . . . . . . . . . . . . . . 113

5.3.2 Inversion Results with the Geometrical Approach . . . . . . . . 115

5.3 .2 .1 Com Sample ................. 116

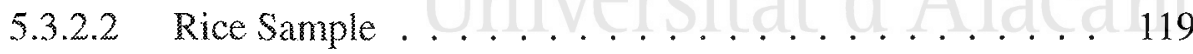

5.3 .2 .3 Non-Fully Polarimetric Data ............... 123

5.3 .3 Inversion Results With The Hybrid Approach . . . . . . . . . . . . 124

5.3.4 Inversion Results With a Dual-baseline Configuration . . . . . . . 126

5.3 .5 Requirements for Space-borne Systems . . . . . . . . . . . . 129

5.4 Conclusions . . . . . . . . . . . . . . . . 131

6 Characterization of the CM Response of Maize Crops: Range Profies 143

6.1 Methodology and Experiment Description . . . . . . . . . . . . . . . . . 144

6.1.1 Experimental Data . . . . . . . . . . . . . . . . . . . 144

6.1 .2 Data Processing. . . . . . . . . . . . . . . . 144

6.2 Analysis of Results . . . . . . . . . . . . . . . . . 146

6.2 .1 Power Backscatter Profles . . . . . . . . . . . . . . . . 147

6.2.1.1 Power Profiles in the Linear Basis . . . . . . . . . . . 147

6.2.1.2 Power Profles in the Pauli Basis . . . . . . . . 150

6.2 .1 .3 Differential Extinction Estimation . . . . . . . . 152

6.2 .2 Polarimetric decomposition profles . . . . . . . . . 154

6.3 Conclusions . . . . . . . . . . . . . . . 156

7 Conclusions

Publications

$\begin{array}{ll}\text { Bribliography } & 186\end{array}$

xxiii

Tesis doctoral de la Universidad de Alicante. Tesi doctoral de la Universitat d'Alacant. 2007. 


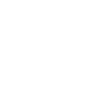




\section{List of Tables}

1 Comparació de l'error d'estimació obtingut per cada procediment d'inversió per a l'altura de la planta i la topografia del sòl. . . . . . . . . . . . x xvi

4.1 Total propagation paths depending on the working mode of the interferometer. . . 77

5.1 Comparison of the retrieval accuracy provided by each inversion procedure for height and topography. . . . . . . . . . . . . . . . . . . 129 

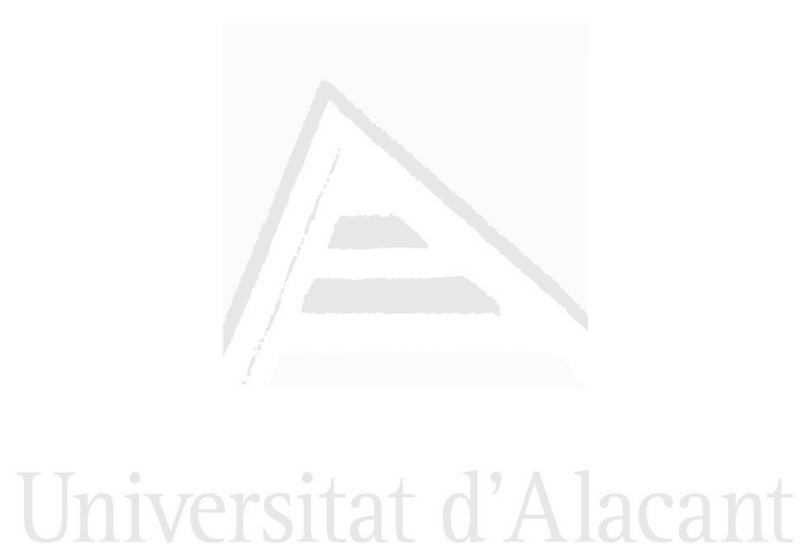


\section{List of Figures}

3.1 SAR imaging system geometry $\ldots \ldots \ldots \ldots \ldots \ldots$

3.2 Distributed scatterer imaging geometry $\ldots \ldots \ldots 26 \ldots \ldots$

3.3 Total SAR reflectivity represented on the complex plane $\ldots \ldots \ldots 28$

3.4 Probability density functions for a complex SAR image: a) Amplitude; b) Intensity; c) Phase . . . . . . . . . . . . . . . . . . . . .

3.5 Single-look distribution for the phase of the Hermitian product of a pair of SAR images. Effect of the magnitude of the correlation coefficient $|\rho|$. Plots have been obtained with $\phi_{0}=0$ rad $\ldots \ldots \ldots \ldots \ldots$

3.6 Multi-look distribution for the phase of the Hermitian product of a pair of SAR images for different number of looks. Plots have been obtained with $\phi_{0}=0 \mathrm{rad}$ and

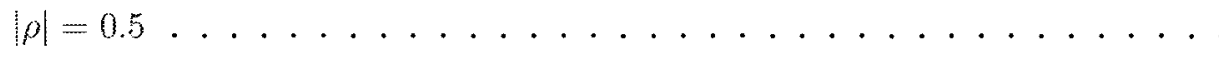

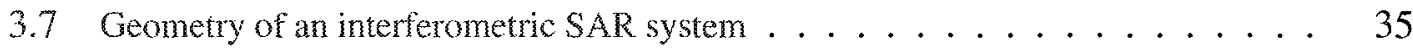

3.8 Calculation of $\Delta r=r_{1}-r_{2}$ for an interferometric SAR system $\ldots \ldots 37$

3.9 Spherical coordinate system for a plane wave . . . . . . . . . . . . 42

3.10 The polarization ellipse in the $v-h$ plane $\ldots \ldots . \ldots 44$

3.11 BSA (left) and FSA (right) conventions . . . . . . . . . . . 47

3.12 Relationships among scattering descriptors. Transition from power descriptors to the scattering matrix is only possible if the rank of the coherency matrix is equal to

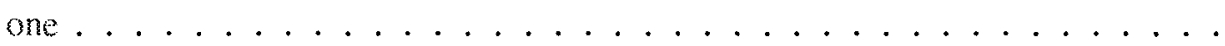

4.1 Contributions considered in the full-wave scattering model. . . . . . . . . . . 61

4.2 Backscattering coefficient from a perfectly conducting square plate as a function of incidence angle: a) Linear scale ; b) dB scale . . . . . . . . . . . . . .

xxvii 
4.3 Propagation paths for each scattering mechanism. . . . . . . . . . 63

4.4 Interferometric scattering geometry for the RVoG and the OVoG models. . . . . 65

4.5 Volume and double bounce contributions due to a scatterer at $\vec{R} . \ldots \ldots 7$

4.6 Loci of possible coherences of the RVoG model for single-tx (left) and alternate-tx (right) modes. Parameters: $\theta_{0}=45^{\circ}, \kappa_{z}=0.75, \phi_{0}=-40^{\circ},-40 \mathrm{~dB} \leq \mu_{\hat{\gamma}} \leq+40$ dB. Cases: $(\mathrm{a}-\mathrm{b}) \sigma_{x}=1 \mathrm{~dB} / \mathrm{m}, h_{v}=1,1.5$ and $2 \mathrm{~m} ;(\mathrm{c}-\mathrm{d}) \sigma_{x}=0,1$ and $4 \mathrm{~dB} / \mathrm{m}, h_{2}=$

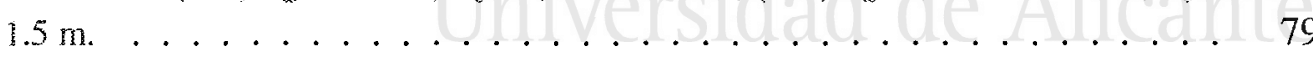

4.7 Wave propagation through an oriented volume. . . . . . . . . .

4.8 Loci of possible coherences of the OVoG model for single-tx (a) and alternate-tx (b) modes. Parameters: $\theta_{0}=45^{\circ}, \kappa_{z}=0.75, \phi_{0}=-40^{\circ},-40 \mathrm{~dB} \leq \mu_{r_{e} t_{e}} \leq+40 \mathrm{~dB}$. Data: $\sigma_{a}=3 \mathrm{~dB} / \mathrm{m}, \sigma_{b}=0 \mathrm{~dB} / \mathrm{m}, h_{v}=2 \mathrm{~m} \ldots \ldots \ldots \ldots$

4.9 Loci of possible coherences of the OVoG model for single-tx as a function of bistatic angle: a) $\theta_{0}=25^{\circ}$ : b) $\theta_{0}=45^{\circ}$. Parameters: $f=9.65 \mathrm{GHz}, \delta=\theta_{0}, H=514 \mathrm{~km}$, $z_{0}=-0.7 \mathrm{~m},-40 \mathrm{~dB} \leq \mu_{r_{\mathrm{e}} L_{\mathrm{e}}} \leq+40 \mathrm{~dB}(-10 \mathrm{~dB}$ and $+10 \mathrm{~dB}$ values are marked with bigger dots $), \sigma_{a}=3 \mathrm{~dB} / \mathrm{m}, \sigma_{b}=0.5 \mathrm{~dB} / \mathrm{m}, h_{n}=2 \mathrm{~m} \ldots \ldots \ldots$

5.1 Two-layer vegetation model. (a) Geometry of a vegetation volume over the ground. (b) Coherency functions of both layers. . . . . . . . . . . .

5.2 Feasible region of the coherence in the complex plane. Parameters: $h_{v}=2 \mathrm{~m}$, $\phi_{0}=20^{\circ}, k_{z}=0.5,0<\sigma<3 \mathrm{~dB} / \mathrm{m}$. (a) Complete unit circle. (b) Zoom of the feasible region, with indication of the borders $\ldots \ldots \ldots \ldots$

5.3 Feasible region of the coherence in the complex plane, in the case of tall vegetation. Parameters: $h_{v}=5 \mathrm{~m}, \phi_{0}=20^{\circ}, k_{z}=0.5,0<\sigma<3 \mathrm{~dB} / \mathrm{m} . \ldots \ldots$

5.4 Feasible region of the coherence in the complex plane. Parameters: $h_{v}=2 \mathrm{~m}$, $\phi_{0}=20^{\circ}, k_{z}=1.04$. (a) RVoG with $\sigma=1 \mathrm{~dB} / \mathrm{m}$. (b) OVoG with $\sigma_{1}=0 \mathrm{~dB} / \mathrm{m}$ and

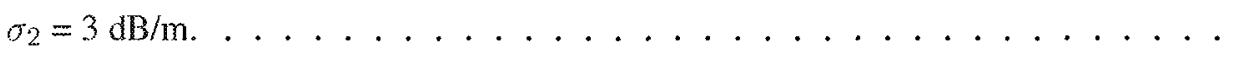

5.5 Experimental coherences on the complex plane for the corn sample. Parameters: $f=3 \mathrm{GHz}, B=0.5^{\circ}, k_{z}=1.56$. (a) Coherences for linear basis, Pauli basis and optimized ones. (b) Possible lines from the exact topographic phase. (c) Overlay of the theoretical region with $h_{v}=1.80$. (d) Overlay of the theoretical region with $h_{v}=1.50$. (e) Overlay of the visible region and the theoretical region with $h_{v}=1.50 .106$

5.6 Visible region of the coherences for the maize sample $\left(f=6 \mathrm{GHz}, B=0.25^{\circ}\right)$ and the nice sample $\left(f=8 \mathrm{GHz}, B=0.5^{\circ}\right) \ldots \ldots \ldots \ldots \ldots \ldots$

5.7 Ilustration of the effect of multiple scattering on the phase center distribution. . . 107 
5.8 Proposed inversion algorthm for agricultural vegetation. (a) Line fitting and ground topography estimation. (b) Set of lines containing coherences and topographic phase $\phi_{0}$. (c) Representation of the volume coherence for extreme extinction values, $\gamma_{v}\left(h_{v}, \sigma_{\min }\right)$ and $\gamma_{v}\left(h_{v}, \sigma_{m a x}\right)$, and region of possible solutions for the vegetation height $h_{v} \ldots \ldots \ldots \ldots \ldots \ldots$. . . . . . . . . . . . . . . . .

5.9 Valid solutions for the random volume model. . . . . . . . . . . . . . 110

5.10 Block diagram of direct model. . . . . . . . . . . . . . . . 112

5.11 Block diagram of inversion algorithm based on the hybrid approach. . . . . . . 113

5.12 Photographs of the agricultural samples measured at the EMSL: (a) Com. (b) Rice. 114

5.13 Setup of the experiments at the EMSL . . . . . . . . . . . . 115

5.14 Block diagram for the spectral overlap in the interferometric pair. . . . . . . 116

5.15 Example of the inversion algorithm with data from the con sample. $f=4.5 \mathrm{GHz}$, $B=0.25^{\circ}, k_{z}=1.16 \ldots \ldots \ldots \ldots \ldots$

5.16 Retrieval results for the maize sample as a function of frequency. $B=0.25^{\circ}, k_{z}=$ $0.26 \cdot f(\mathrm{GHz})$. Solid line with circles: standard RVoGestimates $(\sigma=0 \mathrm{~dB} / \mathrm{m})$. Solid line with error bars: mean and standard deviation of the set of possible solutions. Dashed line: true value. . . . . . . . . . . . . . . . .

5.17 Retrieval results for the maize sample as a function of frequency. $B=0.5^{\circ}, k_{z}=$ $0.52 \cdot f(\mathrm{GHz})$. Solid line with circles: standard RVoG estimates $(\sigma=0 \mathrm{~dB} / \mathrm{m})$. Solid line with error bars: mean and standard deviation of the set of possible solutions. Dashed line: true value. . . . . . . . . . . . . . . . . . . . .

5.18 Average coherence as a function of frequency for the maize sample. . . . . . .

5.19 Distribution of coherence points in the complex plane at different frequencies. Target: Maize sample. $B=0.25^{\circ} . \ldots \ldots \ldots \ldots$

5.20 Retrieval results for the rice sample as a function of frequency. $B=0.25^{\circ}, k_{z}=$ $0.26 \cdot f(\mathrm{GHz})$. Solid line with circles: standard RVoG estimates $(\sigma=0 \mathrm{~dB} / \mathrm{m})$. Solid line with error bars: mean and standard deviation of the set of possible solutions. Dashed line: true value. . . . . . . . . . . . . . .

5.21 Retrieval results for the rice sample as a function of frequency, $B=0.5^{\circ}, k_{z}=$ $0.52 \cdot f(\mathrm{GHz})$. Solid line with circles: standard RVoG estimates $(\sigma=0 \mathrm{~dB} / \mathrm{m})$. Solid line with error bars: mean and standard deviation of the set of possible solutions. Dashed line: true value. . . . . . . . . . . . . . . . . . .

5.22 Retrieval results for the rice sample as a function of frequency. $B=1^{\circ}, k_{z}=$ 1.04. $f(\mathrm{CHz})$. Solid line with circles: standard RVoG estimates $(\sigma=0 \mathrm{~dB} / \mathrm{m})$. Solid line with error bars: mean and standard deviation of the set of possible solutions. Dashed line true value. . . . . . . . . . . . . . . 
5.23 Distribution of coherence points in the complex plane for the rice sample at $5 \mathrm{GHz}$ and $B=0.5^{\circ}$

5.24 Retrieval results for the maize sample as a function of frequency. (a) Coherence points for the Pauli basis. (b) Coherence points for the lexicographic basis. $B=$ $0.25^{\circ}, k_{z}=0.26 \cdot f(\mathrm{GHz})$. Solid line with circles: standard RVoG estimates $(\sigma=$ $0 \mathrm{~dB} / \mathrm{m}$ ). Solid line with error bars: mean and standard deviation of the set of

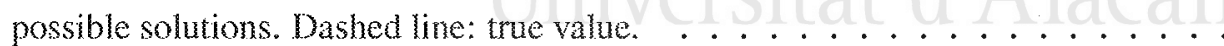

5.25 Retrieval results for the maize sample as a function of frequency. $B=0.25^{\circ}$, $k_{z}=0.26 \cdot f(\mathrm{GHz})$. (a) Coherence points for $\mathrm{HH}$ and HV channels. (b) Coherence points for VV and HV channels. (c) Coherence points for HH+VV and HH-VV channels. Solid the wim circles: standard RVoG estimates $(\sigma=0 \mathrm{~dB} / \mathrm{m})$. Solid line with error bars: mean and standard deviation of the set of possible solutions. Dashed line: true value. . . . . . . . . . . . . . . . . . . .

5.26 Estimation procedure for the maze sample $\left(\mathrm{B}=0.25^{\circ}\right)$ at $5.5 \mathrm{GHz}$ and $7.6 \mathrm{GHz}$ by only using the copolar channels. When only two coherence values are considered a slight difference on the location of those complex values can produce wrong estimates, since the fitted line can take any orientation. . . . . . . . . . . . . . .

5.27 Height estimates with the hybrid approach for the com sample as a function of frequency. a) $B=0.25^{\circ}, k_{z}=0.26 \cdot f(\mathrm{GHz})$; b) $B=0.5^{\circ}, k_{z}=0.52 \cdot f(\mathrm{GHz})$.

5.28 Extmction coeficients estimates with the hybrid approach for the corn sample as a function of frequency, a) $B=0.25^{\circ}, k_{z}=0.26^{\circ} \cdot f(\mathrm{GHz})$ b) $B=0.5^{\circ}, k_{z}=$ $0.52 \cdot f(\mathrm{GHz}) \ldots \ldots \ldots \ldots$

5.29 Ground-tow volume estimates with the hybrid approach for the corn sample as a function of frequency. a) $B=0.25^{\circ}, k_{z}=0.26 \cdot f(\mathrm{GHz})$; b) $B=0.5^{\circ}, k_{z}=0.52 \cdot f(\mathrm{GHz}) .136$

5.30 Height estimates with the hybrid approach for the rice sample as a function of frequency. a) $B=0.5^{\circ}, k_{z}=0.52 \cdot f(\mathrm{GHz})$; b) $B=1^{0}, k_{z}=1.04 \cdot f(\mathrm{GHz}) . .$.

5.31 Bxinction coefficients estimates with the hybrid approach for the rice sample as a function of frequency. a) $B=0.5^{\circ}, k_{z}=0.52 \cdot f(\mathrm{GHz})$; b) $B=1^{\circ}, k_{z}=$ $1.04 \cdot f(\mathrm{GHz}) \ldots \ldots \ldots \ldots$

5.32 Gromd-to-volume estimates with the hybrid approach for the rice sample as a function of frequency. a) $B=0.5^{\circ}, k_{z}=0.52 \cdot f(\mathrm{GHz})$; b) $B=1^{\circ}, k_{z}=1.04 \cdot f(\mathrm{GHz}) .137$

5.33 Block diagram of inversion algorihm with dual-baseline data. . . . . . . . 138

5.34 Inversion results with dual-baseline for the maize sample (2-6 GHz). $B=0.25^{\circ}$ and $0.5^{\circ}$.

(a) Ground topography and volume height estimates. (b) Extinction coefficients estimates. (c) Ground-to-volume ratio estimates. . . . . . . .

5.35 Inversion results with dual-baseline for the rice sample $(5-9 \mathrm{GHz}) . B=0.5^{\circ}$ and 1\%. (a) Ground topography and volume height estimates. (b) Extinction coeffictents estimates. (c) Ground-to-volume ratio estimates. . . . . . . . . . . . 
5.36 Baseline effect on the width of the coherence region. Plot of the slope difference between extreme lines (copolar channels) of the coherence region. Parameters: $k_{z}=3.1 \cdot B$ (degrees) $f=3 \mathrm{GHz}, \sigma_{a}=3 \mathrm{~dB} / \mathrm{m}, \sigma_{b}=0.5 \mathrm{~dB} / \mathrm{m}$, $\theta_{0}=45^{\circ}, z_{0}=-70 \mathrm{~cm}, h_{v}=2 \mathrm{~m}$. Zero slope difference values (circles) correspond to baselines which make the coherence region to become a single line . . . . . . . . . . . . . . . . . .

5.37 Normal baseline to wavelength ratio as a function of volume height. Dotted and solid lines correspond to 2.74 and 0.52 wavenumbers, respectively, obtained from the maize sample. Parameters: $h_{v}=1.8 \mathrm{~m}, \theta_{0}=45^{\circ}$, $H=550 \mathrm{Km} \ldots \ldots \ldots \ldots \ldots \ldots \ldots \ldots$

5.38 Normal baseline as a function of frequency for a $1.8 \mathrm{~m}$ volume height. Dotted and solid lines correspond to the limits by low coherence and volume sensitivity, respectively. Lines with points represent the critical normal baseline for different bandwidths. Parameters: $\theta_{0}=45^{\circ}, H=550 \mathrm{Km}$. . . . .

6.I Imaging geometry and coordinate system $\ldots \ldots \ldots \ldots$

6.2 Effect of the finite size of the target and the rotation in azimuth $\ldots \ldots \ldots$

6.3 RCS profiles at linear basis (HH, HV and VV) as a function of slant-range for $\mathrm{S}, \mathrm{C}$

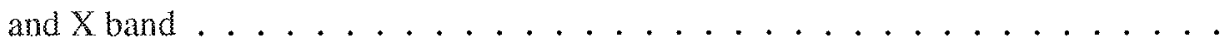

6.4 Differences in RCS between dominant polarizations at 2,4,6 and $8 \mathrm{GHz}$. Left: $|H H|-|V V|$. Right: $|H H+V V|-|H H-V V| \ldots \ldots \ldots$

6.5 RCS profiles at Pauli basis (HH+VV, 2HV and HH-VV) as a function of slant-range for $\mathrm{S}, \mathrm{C}$ and $\mathrm{X}$ band $\ldots \ldots \ldots \ldots \ldots \ldots$

6.6 Estimated differential extinction coefficient between vertical and horizontal polarizations as a function of frequency $\ldots \ldots \ldots \ldots \ldots$

6.7 Target decomposition parameters as a function of slant-range for $\mathrm{S}, \mathrm{C}$ and $\mathrm{X}$ band. From left to right: Probabilities of the three eigenvectors, $\alpha$ of the three scattering mechanisms, average alpha angle $\bar{\alpha}$, entropy $H$ and anisotropy $A \ldots \ldots$. . .

6.8 Measured slopes of $\alpha$ with $r$, as a function of frequency $\ldots \ldots \ldots$ 


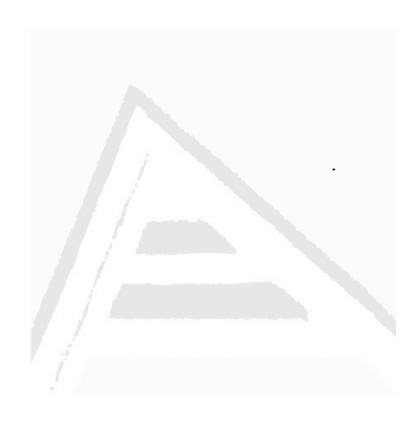

canese 1

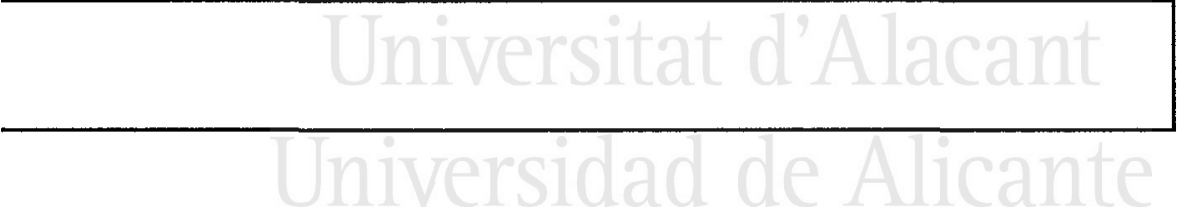

\section{Introduction and Scope of this Thesis}

Monitoring the Earth's vegetation cover is an important application of microwave remote sensing. The interests of the scientific community are presently focused on two types of vegetation covers: forests and agricultural crops. Forests are of prime interest for climate change studies because of the relevance of forest biomass in the global carbon cycle. On the other hand, the interest in monitoring agricultural crops relies on their economic and social impact. As an example, three of the world's four most populous nations are rice-based societies: China, India, and Indonesia, which means nearly 2.5 billion people. As a result, the development of techniques to monitor agricultural crops at large scale is nowadays an issue of primary importance in order to perform a rational management of the Earth natural resources.

Remote sensing systems can be implemented by means of active or passive sensors depending upon the source of illumination. Active sensors are equipped with their own illuminating system and measure the electromagnetic radiation scattered off the scene. On the other hand, passive sensors perform measurements of the radiation emitted by the scene or reflected by another source e.g. the Sun.

These systems can be also classified in accordance with the frequency range of the sensor. In general, remote sensing systems for Earth observation can be implemented by means of optical and microwave sensors. There exists several advantages that make microwave active sensors a powerful tool for monitoring the Earth cover, namely, 1) their independence of weather and illumination conditions, 2) the capability of microwaves to penetrate into the vegetation structure, snow and ground surface, and 3) a high sensitivity to characteristic parameters of targets, such as the roughness or the water content.

Synthetic aperture radars (SARs) constitute the key point in the development of techniques for monitoring the Earth surface due to the capability of providing high resolution microwave images. Furthermore, there exist ways to obtain additional advantages from SAR systems by post-processing sets of SAR images acquired with different configurations (frequency, polarization, incidence angle, etc). For example, three of these techniques, which will be 
treated in this thesis are: SAR interferometry (InSAR), SAR polarimetry (PolSAR), and polarimetric SAR interferometry (PolInSAR).

SAR interferometry has been extensively applied for Digital Elevation Model (DEM) generation and surface change detection, whereas PolSAR-based systems are used in order to extract features related to physical properties of targets. In both cases, the dimensionality of the observation space is increased and, hence, the accuracy of the retrieved biophysical parameter improves.

Nevertheless, the scattering processes inside the vegetated medium exhibit a high complexity due to the vegetation morphology and the complex processes of electromagnetic interaction between radar signals and vegetation elements. As a result, natural targets are characterized by many geo- and biophysical parameters. A group of techniques based on merging the polarimetric and the interferometric information have been developed in the last ten years in order to overcome some of the limitations of InSAR and PolSAR approaches. These techniques, known as PolInSAR, are implemented by means of sensors equipped with multipolarization and, in some cases, multi-baseline capabilities.

During the last years, a number of spaceborne and airborne sensors have been providing polarimetric and/or interferometric data which have been extensively used by the scientific community in order to improve active microwave remote sensing techniques. The Shuttle Imaging Radar (SIR-C) and the Shuttle Radar Topography Mission (SRTM) were space shuttle missions with a capability to operate in repeat-pass and single-pass modes, respectively. The former provided fully polarimetric (quad-pol) data at L-C bands and the latter is equipped with a SAR interferometer at $\mathrm{C}-\mathrm{X}$ bands in order to map the earth surface topography between $\pm 60^{\circ}$ latitude. In addition, other spaceborne-based sources of data are ERS-2, operating at C-band and the VV channel, Radarsat- 1 at C-band and $\mathrm{HH}$ channel, and ASAR (ENVISAT) at C-band with co or cross polar channels (AP mode).

More recently, in 2006 the PALSAR (Phased Array L-band SAR with quad-pol capability) system on ALOS satellite developed by the Japan Aerospace Exploration Agency (JAXA) started to operate. Its aim is to provide high-resolution data for environmental and hazard monitoring. In addition, in summer 2007 it is scheduled to launch the German radar satellite TerraSAR-X and the Radarsat-2 developed by the Canadian Space Agency. TerraSAR$\mathrm{X}$ carries an X-band sensor which can be operated in multiple modes (spotlight, stripmap, scanSAR) and polarizations (dual-polarization as the operational mode and quad-polarization as an experimental mode). It can also operate as a receiver of interferometric radar data in order to implement along track interferometry for velocity mapping. On the other hand, Radarsat-2 will provide fully polarimetric data at C-band.

It must be outlined that the availability of data sets is very scarce because this kind of systems have been designed only very recently. In addition, at the present moment there are no operating satellites with PolInSAR single-pass capabilities and therefore the development of inversion techniques is still limited.

With regard to airborne systems, the measurement campaigns carried out by E-SAR (Ger- 
man Aerospace Center, DLR) as well as AIRSAR (JPL/NASA) systems must be mentioned, both with fully polarimetric interferometric capabilities at $\mathrm{P}$ and $\mathrm{L}$ bands. In the case of $\mathrm{E}$ SAR, reduced polarization channels are also possible at $S, C$ and $X$ bands and, in the case of AIRSAR, it is possible to provide the whole scattering matrix at C-band. Besides, special attention deserves the experimental airborne SAR system developed by the French Aerospace Agency (ONERA), called RAMSES, which provides quad-pol measurements from P-band to $\mathrm{Ku}$-band, and copolar and circular polarizations for $\mathrm{Ka}$ and $\mathrm{W}$ bands. Furthermore, $\mathrm{X}$ and $\mathrm{Ku}$ bands are used to implement single-pass interferometry, either in across-track or alongtrack modes. Another example of operating system is PiSAR operated by JAXA/NICT, which provides X-and L-band fully polarimetric measurements. Finally, note that EMISAR sensor (Danish Center for Remote Sensing (DCRS)) which is no longer an operating system, acquired $\mathrm{L}$ - and $\mathrm{C}$-band fully polarimetric data.

Despite the advanced development stage of current air- and spaceborne platforms and radar remote sensing techniques, a lot of work is still to be done. For example, the high variability found in the morphology of land covers introduces important limitations in the range of applicability of inversion algorithms, also depending upon the sensitivity of the sensors to the structures of the scene.

The estimation of biophysical parameters is founded on a precise knowledge of the electromagnetic scattering mechanisms that characterize the vegetation cover and, as a consequence, a previous stage before the implementation of reliable techniques for air- and spaceborne systems consists of validating the retrieval algorithms under controlled conditions. This aim is accomplished by means of simulations and ground-based radars, which are widely used in order to get an accurate description about the scattering response of natural and man-made targets without the influence of the environment. In addition, they allow a high flexibility in the configuration of operating parameters, such as frequency, polarization and baseline. Therefore, these systems are used in order to study and to define accurately the operation modes for future SAR missions.

The testing and validation of vegetation parameters inversion techniques by means of groundbased radars establishes the framework of the present thesis. Conclusions obtained from the work presented here are supported by the information extracted from wide-band fully polarimetric indoor measurements acquired at the European Microwave Signature Laboratory (EMSL), Ispra, Italy.

The scope and objectives of this thesis are drawn in the next section.

\subsection{Objectives of this Thesis}

Although PollnSAR has been successfully used for the estimation of forest parameters, its application is not straightforward when dealing with other kinds of vegetation, such as agricultural crops, since their electromagnetic response exhibit different features. The vertically 
oriented structures characterizing many types of crops make these vegetation morphologies to be known as oriented volumes. In this case, the wave propagation becomes anisotropic, i.e. it suffers from a polarization dependent attenuation. In addition, the short height of crops makes the ground contribution very significant as a consequence of the low attenuation of the wave penetrating into the volume. Consequently, a deeper analysis about the electromagnetic behavior of agricultural crops is required in order to characterize more precisely these kinds of vegetation. This task can be carried out by means of direct electromagnetic modelling. As will be explained in Chapter 2, there exist different strategies to develop direct models of vegetated scenes. One of the most widely used is that based on a statistical description of the interaction between the electromagnetic wave and the natural medium, which does not require the computation of the contributions of every single scattering particle inside the medium. Another important advantage of such statistical approach is that it allows a very simple physical interpretation of the scene under observation, since it can be described by means of a reduced set of geo- and biophysical parameters.

This strategy provides two models accounting for different morphologies of vegetation, which are known as random and oriented volumes. In practice, at P- and L-band forest areas, which are characterized by a dense canopy located at the upper layer, can often be treated by a collection of scattering particles randomly located and orientated. Accordingly, the wave propagation is governed by an isotropic behavior, i.e. the attenuation is polarization independent. At the lower layer, composed by soil and tree trunks sufficiently separated from each other, the ground-trunk interaction dominates the backscattering and, as a consequence, it is possible to determine the vertical structure of such scenario by using the PolInSAR observables. Due to these features, forest can be modelled as a random volume over a ground surface (RVoG). Nevertheless, the assumption of random volume for forests must be treated carefully, since it is not strictly true specially at P-band [BA01].

On the other hand, many agricultural crops such as maize, rice, or wheat are composed by structures with predominant vertical orientations, despite leaves and upper parts of stems bent down. In this case, the wave propagation becomes anisotropic and, hence, the attenuation depends on polarization. In addition, the short thickness of vegetation volume could make the ground and ground-stem contributions to be very important in the total backscattering response. Consequently, this type of vegetation can be modelled as an oriented volume over ground (OVoG).

In this context, the aim of this thesis copes with the retrieval of biophysical parameters of agricultural crops by using polarimetric SAR interferometry and simple electromagnetic models such as RVoG and OVoG models.

Firstly, this thesis deals with the analysis of the validity of the random volume over ground (RVoG) model for the estimation of crop height, underlying topography and differential extinction coefficient when PolInSAR measurements are available. Our observations have been derived in terms of the location of the complex coherence points on the complex plane, as indicated originally by Cloude and Papathanassiou [PCOl] for forest parameter retrieval.

The assessment of the validity of this type of model when applied to an oriented volume, 
such as maize and rice crops, will reveal a new feasible region of the observed complex coherences, which concerns the second part of this thesis. In particular, the inversion problem will be addressed by investigating the correspondence between the region occupied by the experimental complex coherences and the location of the coherences provided by the oriented volume over ground (OVoG) model. Note that the effect of the ground surface for an oriented volume, which had not been previously considered in the literature, has been taken into account in this analysis. The suitability of such a model will be discussed by analyzing the influence of the parameters of interest, namely, vegetation height, ground topography, extinction coefficients, and differential extinction coefficient, as well as the system parameters (frequency, baseline, etc.).

A discussion about the retrieved estimates provided by the inversion algorithms for the RVoG and $\mathrm{OVoG}$ will be also given.

As will be shown, the role of the extinction coefficient and its physical interpretation must be still clarified. This parameter appears in the direct electromagnetic modelling when the attenuation of the propagated wave is taken into account. Therefore, its effect can be directly interpreted as propagation losses in the wave propagation when the scattered field magnitude or its power are calculated. However, its influence on the PolInSAR observables, i.e. the normalized cross correlation for each polarization channel, is not evident. Indeed, it will be shown that large variations of extinction will lead to negligible changes on the location of complex coherences and, hence, this lack of sensitivity disables its estimation by means of the inversion process based on a geometrical approach by using the OVoG or the RVoG models.

Besides, it must noted that the inversion problem presents a high nonlinearity and, hence, complementary inversion approaches will be proposed. On the one hand, an hybrid procedure, based on geometrical and numerical steps, will be tested. On the other hand, a dual-baseline configuration will be used in order to enlarge the dimension of the observation space.

Finally, an alternative analysis of the electromagnetic response of a maize sample will be performed by means of high resolution backscatter range profiles as a function of wave penetration. The aim of this part of the thesis is twofold. Firstly, an alternative approach for the differential extinction coefficient estimation will be explored by analyzing the backscattering range profiles of crops in linear and Pauli basis. Secondly, the variation as a function of the penetration depth of the polarimetric parameters from the Cloude-Pottier decomposition [CP96, $\mathrm{CPO} 7]$ will be used in order to obtain complementary information about the scattering processes that take place along the volume. Conclusions from these observations will allow us to provide estimates of the differential extinction coefficient as well as to obtain further information about the electromagnetic characterization of crops in terms of their polarimetric response. 
Summarizing, the objectives of this thesis are stated as follows:

- To study and analyze the applicability of the RVoG model for the estimation of biophysical parameters for agricultural crops. This will be particularized to two cases: maize and rice.

- To develop and test an inversion algorithm for agricultural crops modelled under the assumptions of the OVoG model. As a previous step it is necessary to consider the influence of the ground surface for an oriented volume, which had not been treated before in literature. A formal expression for the polarimetric cross-correlation products will be obtained for this scenario.

- As will be observed, the inversion problem suffers from an indetermination in the OVoG case. Therefore, some alternative strategies for a full parameter estimation will be also investigated. They will be based either on a hybrid approach, i.e. geometrical and numerical, and on a numerical approach with a dual-baseline configuration of the interferometer.

- To study and analyze the electromagnetic response of crop samples by means of power range profiles and their polarimetric analysis, as a function of wave penetration, in order to extract information about the vertical structure of crops.

\subsection{Organization of this Thesis}

The text of this thesis has been divided into seven chapters. This chapter contains a general presentation of the thesis and its objectives.

Chapter 2 is aimed to provide an overview of the evolution and current status of active microwave remote sensing techniques, applied to vegetation parameter retrieval, in order to contextualize and justify the work carried out in this thesis.

In Chapter 3, the theoretical background of radar remote sensing is addressed, focusing the attention on radar polarimetry and SAR interferometry.

Chapter 4 presents the existing strategies for coherent electromagnetic modelling, i.e. the full-wave scattering model, and the random (RVoG) and oriented volume (OVoG) models. The aim of this chapter is to gain a deeper understanding of the RVoG and OVoG models in order to analyze their potential for inversion of agricultural crops parameters. Besides, the contribution of the interaction between the ground surface and the vegetation stems to the polarimetric complex coherence for the oriented volume has been introduced in the OVoG case, since this effect has not been yet quantified in previous works.

Chapter 5 can be divided into two parts. First, an existing PolInSAR-based inversion algorithm, originally developed for forest parameters estimation and founded on the RVoG 
model, is applied to agricultural crops, specifically maize and rice crops. As will be discussed, a successful inversion is possible if certain conditions imposed on the configuration of the interferometer are observed. An analysis of sensitivity of the RVoG model will reveal an ambiguity in the estimation of the extinction coefficient. Conclusions from the application of the RVoG will lead to the definition and validation of an inversion algorithm suited for oriented volumes, characterized by structures with a well-preferred orientations and, hence, a strong anisotropic electromagnetic response.

The second part of Chapter 5 is devoted to explore different approaches for inverting the RVoG and the OVoG equation systems, characterized by a high nonlinearity, that will yield the final estimates. On the one hand, the RVoG-based estimation process is a well-determined problem since the observation space dimension equals the number of unkowns to be estimated, namely, vegetation height, ground topography, extinction coefficient (which is polarization independent) and three values for the ground-to-volume ratio, corresponding to the three polarization channels in the linear basis. Besides, if different polarization basis were used the observation space dimension would be even greater than the number of unkowns. On the other hand, when dealing with an oriented volume there appears an indetermination in the problem since the number of unknown parameters is increased to seven, due to the dependence on polarization of the extinction coefficient. Then, to solve this indetermination, besides the geometrical approach, two additional inversion strategies will be proposed. First, a hybrid approach, which consists of geometrical and numerical steps. Second, a dualbaseline system, which enlarges the observation space. In both cases the inversion problem is solved.

Furthermore, an analysis of the fidelity of the OVoG model has been performed by comparing the region of possible coherences on the complex plane (i.e. the visible region) provided by the model against the measured data. Finally, issues regarding to the estimation process by using dual-polarization data and parameter requirements for spaceborne systems have been also addressed in this chapter.

In Chapter 6 indoor wide-band polarimetric radar measurements of a corn sample have been used to perform a detailed analysis and characterization of this kind of crop. Firstly, backscatter profiles along slant-range have been computed in order to study the polarization dependence due to the vertical orientation of maize plants. This fact, which also depends on frequency, will be analyzed since it introduces a differential extinction coefficient. The evolution of the difference between HH and VV radar cross sections will be used to derive an estimation procedure for differential extinction from $\mathrm{S}$ to $\mathrm{X}$ band, assuming a homogeneous medium and constrained by the finite size of the corn sample and by the square shape of the platform.

Secondly, in Chapter 6 the polarimetric target decomposition proposed by Cloude and Pottier [CPM, CPG] has been applied as a function of slant-range. This analysis has become very helpful for the interpretation of the scattering processes present in this kind of crop and conclusions derived can be used as complementary information for the application of an oriented volume model scheme. 
In Chapter 7, conclusions and the main contributions of this thesis will be summarized, and the future lines of research outlined.

Finally, the publications in journals and conference proceedings generated during the development of this thesis are listed.
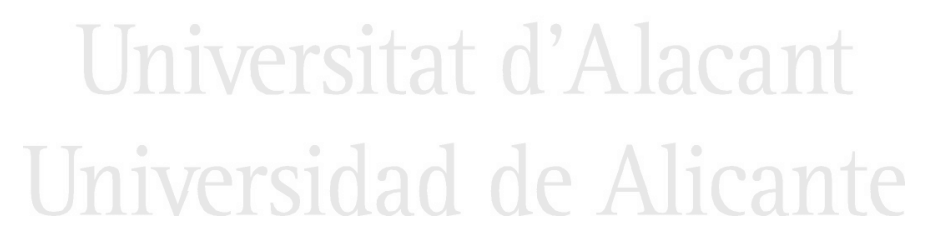


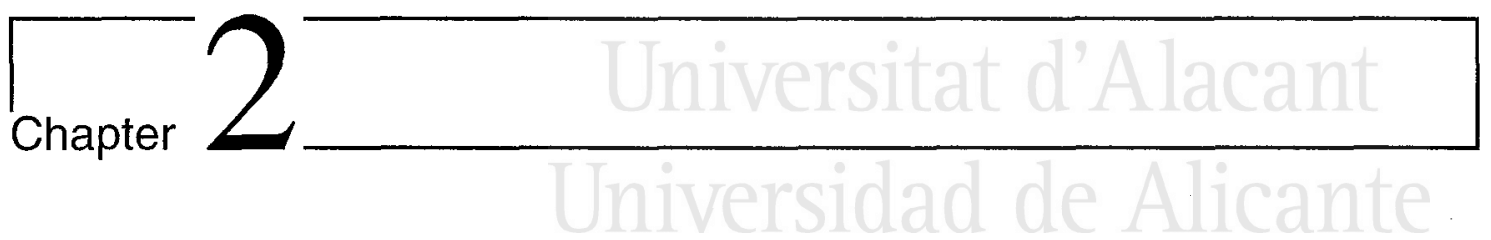

\section{State of the Art}

This chapter is aimed at providing an overview of the current status of investigations about radar techniques for the retrieval of biophysical parameters from vegetated covers. For a more complete description of the historical evolution of radar imaging techniques applied to earth remote sensing see references [UMP81, UMP82, UMP86, Ea88, HL98].

The basic problem faced by microwave remote sensing techniques applied to retrieval of biophysical parameters of vegetation is the definition of realistic and accurate relationships between the morphology and physical characteristics of the scene and the available observables at the radar system. The vegetation medium is usually assumed as a collection of discrete scatterers with different sizes and shapes. On the other hand, the number of observables differ depending on the system configuration.

Historically, in a first stage, a number of retrieval algorithms that make exclusive use of the power images was developed. They calculate estimates of vegetation height, biomass, water content, etc., by means of the backscattering coefficient $\left(\sigma_{0}\right)$, which can been previously modelled by means of an incoherent or a coherent averaging. Most of incoherent approaches are based on the Radiative Transfer (RT) Theory [Cha60], which estimates in an accurate way the second order statistics of the scattered field. Several works have applied this theory to predict the backscatter response from scenes with vegetation covers [USM $\left.{ }^{+} 90, K F 88\right]$, and some of them have become works of reference.

The limitations [LS99a] of this group of techniques arise as a consequence of the inability to properly describe the complexity of the vegetable scene by only using the backscattering coefficient. This drawback can be observed, for example, in forest biomass estimation since above a certain threshold the backscattering coefficient saturates. Although inversion results can be improved by using low frequencies (i.e., L or P-band) [Imn95], the saturation problem is still present.

Hence, the basic idea to overcome the lack of information of these techniques is to develop other systems with appropiate capabilites to measure other observables in addition to the 
power magnitude.

One way to improve the knowledge of the scene is by adding the absolute phase of the scattered field. This is accomplished by means of the coherent approaches. As a result of considering this feature, it is possible to take into account not only the attenuation (as in the RT approach), but also the interaction of scatterers of the medium, i.e., phase interferences, which may produce the wave propagation to be strongly modified depending on the system frequency and on the target configuration [CSOO].

The coherent electromagnetic modelling is divided into two strategies, namely, 1) to compute the response from every single discrete scatterer and even their interaction [LS95], also known as full-wave scattering model (see Section 4.2), or 2) to perform an averaging of the backscattered field by means of a statistical analysis of the signal and the target morphology [TMMv96, TS00].

It is also evident that the limitations of any inversion technique arise from the initial definition of the direct electromagnetic model used for parameters inversion. In this sense, it is extremely important to investigate which are the dominant contributions prevailing in the kind of vegetation cover of interest. For instance, when applied to agricultural fields, the inversion of the plant height can be based on a mathemathical model that mimics the time series of $\sigma_{0}$ obtained from a first-order scattering model [YKJ $+92, \mathrm{LRW}+97$ ]. Another more recent work about coherent first-order scattering modelling is presented in [TCD06], where a $\mathrm{P}$ - and L-band coherent model for forested areas is validated for providing radiometric, interferometric and polarimetric analysis. Besides, the coherent modelling of forests has been also addressed in [NRTO6] and [DSTC06]. In the first case, the integral representation of the electric field has been used in order to simulate the scattered field at frequencies lower than $300 \mathrm{MHz}$, where it is shown that the contribution of small elements compared to the wavelength as well as the soil roughness are negligible. In the second case, a forest canopy is divided into a number of layers. The first-order solution of the radiative transfer equation is used for the trunk layer whereas multiple scattering inside the tree canopy is accounted for by means of the matrix doubling technique. This model has shown a good agreement with experimental data at $\mathrm{L}$ - and X-band.

Nevertheless, it is well known that the use of a first-order scattering approximation underestimates the backscattering coefficient for the cross-polar channel. In [CSOO] a multiple scattering model is applied to investigate the scattering produced by soy plants at L- and C-band, demonstrating that second-order contributions become really important at C-band, and in $[\mathrm{BDW}+06]$ multiple scattering effects are considered for maize crops modelling.

Regarding the electromagnetic modelling of single scatterers, additional efforts are being carried out for a more accurate characterization of vegetation elements (see previous works in [\$SU87, \$SU88, KFA 88]). The effects of leaf geometry and the internal structure of stem are analyzed in [VFG 06]. It is shown that the curvature of long leaves, such as maize leaves, produces a reduction in the backscattering contribution from these particles, while hollow stems [Ko192, VOBFO6], characterizing wheat crops in a mature stage, yield a lower attenuation which, as a consequence, entails a higher response from the soil. 
Other works have investigated important features related to the parameter inversion from crops. In [BQM 03] a deep analysis of high-resolution three-dimensional radar images is used at $\mathrm{C}$ - and $\mathrm{X}$-band to describe the layered structure of the wheat canopy. In addition, a study about wave attenuation is performed, concluding that the use of the forward scattering theorem is not adequate for wheat crops since it overestimates the attenuation of the vertical polarization. On the other hand, in [PLMO3] it is demonstrated with spaceborne data that a multiple scattering model is needed in order to predict more accurately the backscattering coefficient of wheat crops. In that work, a direct relationship was found between the VV channel and the wheat crop height for a $23^{\circ}$ incidence angle.

Besides the only use of amplitude of backscattering from a scene, there exist another means to increase the amount of information acquired by a SAR system, namely, frequency diversity, spatial diversity, i.e. interferometry, and polarization diversity, also known as polarimetry. For the first option, a multi-frequency sensor capable of operating in at least two different spectral bands is required. In fact, several works mentioned within the previous lines have exploited successfully the frequency diversity to estimate physical parameters from vegetation (see also other references later in the text), for example X-and P-band for forested areas (upper and lower layers, respectively).

Nevertheless, it can be stated that polarimetry and interferometry have provided the most promising results in the biophysical parameters retrieval field. On the one hand, polarimetry provides an enlargement of the set of observables by means of the transmission and measurement of different polarization states, which makes the data sensitive to orientations and shapes of the vegetation particles. On the other hand, interferometry requires the observation of the same scene from two (or more) different points. Then, the phase difference between two SAR images, due to the different wave propagation paths, is used to extract the vertical distribution of scattering centers.

Going a step forward, it is still possible to increase the dimensionality of the data through the combination of polarimetry and interferometry, a technique known as polarimetric SAR interferometry (PolInSAR). This technique [CP98] has shown to provide very promising results for the information retrieval from natural covers [CP03] and man-made targets [PPPR05, SPHMO6] and has become object of an intense research activity during the last years.

Next, a brief summary of the applications of polarimetry to remote sensing is provided. Afterwards, the main contributions on interferometry will be described and, finally, the advantages as well as the most outstanding works on PolInSAR will be outlined.

\subsection{Polarimetry}

A natural vegetated medium can be considered a multilayered structure, composed of a variety of scatterers, such as leaves, branches, trunks and ground. These particles contribute to the total electromagnetic response in a different manner depending on their size, orientation, 
shape and dielectric properties, which govern the scattering process. As a matter of fact, radar polarimetry exploits the sensitivity of the wave polarization to those features in order to indentify and separate different scattering mechanisms.

This technique was first applied in 1941 by R. Clark Jones for the characterization of optical systems. Later, in 1950 G. Sinclair [Sin50] introduced the concept known as scattering matrix or Sinclair matrix in order to describe a fully-polarimetric radar system. This matrix constitutes the central element which contains the polarimetric information of a scatterer.

There exists a complete set of mathemathical principles, known as Target Decomposition (TD) theory, intended to retrieve information from the medium by analyzing the scattering matrix. Basically, the TD theory consists of differents approaches that express this matrix as a linear combination of other base matrices, so that each one is associated with a different scattering mechanism present in the medium.

As mentioned before, a natural medium is characterized by the randomness of its structure. This fact entails that several single scatterers can interfere among them, which leads to fading on the signal and, consequently, to a wrong interpretation of the information. To overcome this problem, an average of an appropiate number of independent samples must be performed. This can be achieved by means of spatial [LMMMY4] or frequencial averaging [MVSN94].

TD techniques are divided into three groups [CP96], depending on the average type (coherent or incoherent) and on the analysis carried out on the matrices. A brief description of each group as well as their most outstanding contributions is summarized in the following:

\section{- Coherent decomposition theory}

This approach was developed to characterize completely polarized scattered waves. To do this, the scattering matrix is expressed as a sum of elemental scattering matrices by using coherent averaging.

The drawback of averaging coherently the scattered fields is the existence of interference among all the contributions, which results in a type of noise known as speckle. For a description of fundamentals about speckle filtering see [LID ${ }^{-94}$ ] (see also Section 3.1.2). More recently, the number of looks necessary in order to perform the polarimetric analysis correctly is justified in [LMPO4].

The main work of this type of TD theorems was introduced by E. Krogager in [Kro93] (see also [Kro9s, KC95]) where it was proposed that the scattering matrix could be separated into a sum of the contributions from a sphere, a helix and a diplane.

Other methods that can be found in the literature are the Cameron decomposition [CEL96], which has shown relative success in ship and crashed airplanes detection (bright targets where speckle is negligible), and the symmetric scattering characterization method (SSCM) [TCO2] by Touzi and Charbonneau developed for optimization of target coherent symmetric scattering. 
In general, this theory is useful for high resolution SAR systems, which have the capability to isolate one or two targets within a resolution cell.

\section{- Huynen type decomposition}

In this case the starting point is the Mueller matrix [CP96], which relates the Stokes vector of transmitted and received fields. Therefore, this technique is necessarily based on an incoherent averaging.

The decomposition of the Mueller matrix yields an elemental scattering matrix, which refers to a specific scattering mechanism, plus another contribution which is assumed to correspond to noise.

Nowadays, this type of decomposition is named as the author's name of the first attempt of generalization of TD techniques [Huy 70], although it was ten years earlier, in 1960, when Chandrasekar published the first documented work about this issue [Cha60]. He proposed to decompose the scattering from a cloud of small anisotropic particles into a sum of terms governed by Rayleigh scattering plus a noise term due to the anisotropy of the particles. Another contribution to the Huynen type decomposition techniques was introduced by A Freeman and S L Durden in [FD98]. In this case, the covariance matrix is decomposed into three mechanisms associated with a dihedraltype scattering, a direct surface return and a random volume scattering process, respectively. Although this decomposition is appropriate for classification purposes in forested areas, its range of applicability is reduced [CP96].

\section{- Eigenvector decomposition.}

As in the case of Huynen type decomposition, the eigenvector decomposition theory is based on a matrix resulting from an incoherent averaging of the polarimetric information. This type of TD makes use of the covariance or the coherency matrix, which are equivalent to the Mueller matrix, and is based on an eigenvector analysis. The scattering matrix is expressed by means of a linear combination of elementary scattering matrices, which correspond to the predominant scattering mechanisms contained in the scene. The importance of this mathemathical approach arises from the statistical independence among the three scattering mechanisms, as well as that the fact that the problem becomes basis invariant and, hence, the solutions are unique [CP96].

It can be stated that S. Cloude proposed the first work [Clo86] that addressed the concept of the algebraic description of the scattering processes present in the natural medium by means of the coherency matrix eigenvector decomposition. Here the concept of polarization entropy was introduced to describe the randomness of the interaction between the propagated wave and the medium.

In [CP96], S. Cloude and E. Pottier published a very complete review of all works about TD, and a comparison among them was also provided.

The notion of polarization entropy was applied in [CP95] in order to study multiple scattering of a cloud of particles in the backscattering direction as well as to characterize rough surfaces. Besides, in [CP97] two new parameters were introduced, namely, angles $\alpha$ and $\beta$, which 
refer to the type of elementary scattering mechanism (i.e., direct scattering from a sphere or a flat surface and dipole or dihedral-type scattering) and the orientation of the scatterer, respectively. The utility of entropy, $H$, and $\alpha$ angle has been demonstrated when applied in the classification of polarimetric SAR images, where the $H-\alpha$ plane has been used to identify predominant scattering mechanisms in a scene [CPO7]. The performance of the classification schemes was improved by E. Pottier by means of the use of an additional parameter, called anisotropy [Po198], which accounts for the amount of different types of scatterers within the medium.

Provided the potential capabilities of polarimetry in characterizing the scattering elements without the necessity of an a priori knowledge of the scene, a number of inversion techniques have incorporated the polarimetric information. Thus, in [SLD96, SLA99a, \$LA 996] the topography and the bare surface slope estimation is proposed by using polarimetric SAR images. On the other hand, [CFLSS99] demonstrated the ability of the $H-\alpha$ plane to retrieve the shape and orientation of elementary particles of ficus and fir tree samples.

Another example of the use of radar polarimetry to estimate soil moisture and other vegetation parameters is found in [RDUDO0]]. Here the first order radiative transfer solution is used to interpret the backscattered data from a soybean canopy and it is shown that the cross-polarized backscattering at $\mathrm{L}$ and $\mathrm{C}$-band provides reasonable estimates for soil moisture, whereas a combination of VV and HV channels at L-band results in right estimates for the vegetation water mass, which is related to the biomass. More recently, the potentiality of SAR sensors currently in orbit was investigated for maize monitoring in [BDW 06 ], in order to define the polarizations and incidence angles at $\mathrm{C}$ band that maximize the sensitivity of maize growth and reduce the influence of soil moisture on the signal. A radiative transferbased model was validated for copolar channels by using ERS, ENVISAT and RADARSAT measurements, finding that the VV/VH polarization ratio at high incidence angles (around $45^{\circ}$ ) discriminates different maize growth stages and the $\mathrm{VV} / \mathrm{HH}$ ratio at low incidence angle allows to detect the emergence of these plants.

The use of polarimetry for classification [Cop60, $\mathrm{ST} 83$, van89, CP97] of vegetated areas has experimented also some advances. For a particular classification experiment in the Flevoland agricultural area it is shown [FSS 03 ] that single polarization (HH or VV) achieves an accuracy under $40 \%$, dual polarization achieves a result of $60 \%-70 \%$, and full polarimetry achieves $90 \%$.

More recently, an extension of the Small Perturbation Model (SPM) was proposed in order to estimate separately soil moisture and surface roughness in [HPCO3]. The use of entropy, alpha angle and anisotropy allows a successful parameters retrieval since their use enables to decouple the effects of roughness and moisture content. Hence, anisotropy provides the roughness estimation and entropy and alpha are used to obtain the dielectric constant. Moreover, a new polarimetric parameter called Eigenvalue Relative Difference (ERD) [AFFP03], which is based on the reflection symmetry assumption, has been introduced in order to calculate the surface roughness in a larger validity range than the anisotropy [AFFOA4].

The potential of radar polarimetry has been also exploited in the characterization of snow 
covered areas and sea ice. Here, the most important parameters in the hydrological investigations are snow water equivalence, snow depth, liquid water content as well as snow surface roughness. In principle, the most suitable frequencies for snow and ice microwave remote sensing are $\mathrm{L}$ - and $\mathrm{C}$-bands. Thus, it was shown in [SDR95] that the backscattering at $\mathrm{C}$-band is basically composed by the snow volume contribution and the air-snow interface returns. Hence, it has been developed in [YSSL 04.] a model which simulates snow layer conditions in order to derive an inversion algorithm for snow wetness.

In addition, in [MFFP04] the discrimination of snow covered areas from snow free zones has been addressed by using a polarimetric contrast variation enhancement (PCVE) procedure determines the optimal polarizations states of transmitting and receiving antennas. This method is robust against topographic effects and yields detection probabilities of $75 \%$ for snow covered surfaces and $80 \%$ over snow covered forests, with false alarm probabilities below $1 \%$ and $2 \%$ respectively [MDFPP05].

Polarimetric SAR techniques have also found its application in the monitoring of the human impact at sea. For example, in [For03] the polarimetric descriptors were used to detect and classify oil spills.

From the theoretical point of view, another contribution to radar polarimetry is devoted to analyze more acccurately the statistical behavior of the eigendecomposition applied to PolSAR data. A rigorous mathemathical study reported in [LMPO4] is used to derive the joint sample eigenvalues pdf, which demostrates that the sample eigenvalues are asymptotic non-biased estimators of the true eigenvalues. Besides, the minimum number of samples to be averaged in order to recover the correct polarimetric information is justified.

As can be noted from the previous discussion, the capabilities shown by polarimetry and its application in radar remote sensing have induced a number of works and an increasing research activity regarding the use of this technique. As a consequence of this interest of the scientific community, a considerable part of the efforts are being focused on the design of software tools which have two purposes: 1) the availability of electromagnetic simulators capable to provide information upon the scattering processes present in the scene under study, and 2) the study and a deeper understanding of radar polarimetry. As an example of the first case, in [MBSM03] is presented a SAR simulator which generates polarimetric signatures at high frequency from fishing vessels. Later in [MFMO4] this simulator was used to analyze scattering mechanisms of that type of ships in order to identify and classify vessels. On the other hand, educational aspects have been also addressed by other software tools, such as POLSARPRO [PCD+05], which is a very complete toolbox that allows the user to apply different polarimetric techniques on real spaceborne and airborne data. These functionalities are complemented with a rigorous tutorial on radar polarimetry fundamentals. This toolbox has been developed by the SAPHIR Group of Institut d'Electronique et de Telecommunications de Rennes and at the moment of writting this text, it was available version 2.0 beta 6 , which was released in January 2005 (it can be free downloaded at http://earth.esa.int/polsarpro/). Similarly, the same idea is implemented in a toolbox called RAT (Radar Tools) [RGH 05], which is available on the web and distributed under a free software license. 
In addition, it must be noted that current research concerns bistatic polarimetry, which examines the polarimetric response of targets in a bistatic geometry. In [Clonoa] it is shown the potential of bistatic radar polarimetry for additional information extraction from random volumes and rough surfaces. In this work, a canonical form of the polarimetric coherency matrix for random media is derived based on the symmetry properties of targets, and an extension of the entropy/alpha approach to bistatic scenarios is formulated.

\subsection{SAR Interferometry}

In the following lines, a succinct review of most outstanding achievements on SAR interferometry (InSAR) when applied to retrieval of natural scene parameters will be drawn. Some works reporting thorough reviews on the basics of interferometry are [BH98, RHJ ${ }^{+} 00$, Hanol].

InSAR has become a powerful technique able to discriminate the vertical structure of land covers [TMM V96], since it exploits the phase of a coherent radar signal.

As a matter of fact, the phase information content has been extensively exploited in a number of SAR interferometry applications [WW97, EB98, LS996, Sar97, TMMV96, TS00, PC01]. In all of them a direct model establishing the relationship between the parameters to be estimated (i.e., vegetation height, underlying topography, etc.) and the observables (i.e., interferometric coherence, backscattering coefficient, polarization dependence) is used. Then, an inversion procedure to obtain the unknown parameters from the image data is designed. In [WW97] the potential of InSAR has been exploited for land cover classification and in [EB98] for crops monitoring.

As has already been mentioned, the localization of phase centers inside the natural cover faces the problem of the inherent complexity of vegetation. This does not behave like a well determined set of point scatterers. On the contrary, it must be seen as a set of sparse scatterers, and thus, the interferometric phase becomes a random variable which is in general a function of the system configuration parameters as well as the morphology of the natural cover. Thus, a set of approximations have been proposed for addressing this issue.

In [Sar97] a theoretical approach for vegetation height estimation is presented, which makes use of the frequency correlation function $(\mathrm{FCF})$ and the equivalence between a $\Delta k$-radar, i.e., a system with frequency diversity, and an interferometer. Afterwards the FCF function was used for the estimation of height of grass layers in laboratory conditions [SLN+98]. In [S[, 00$]$, the equivalence between interferometry and a $\Delta k$-radar is used jointly with a coherent scattering model to derive the statistical parameters of the phase centers from several types of trees. Besides, the estimation of the height of forested areas has been treated in [HUA95, ADUS97], making use of a DEM. In particular, in [HUA95] the decrease of coherence when the baseline is increased (with a repeat-pass system) is used to estimate the effective scattering layer thickness, whereas in [ADUS97] a model that relates C-band re- 
peat pass interferometric SAR data from satellite ERS-1 to biophysical parameters has been developed.

Similarly some advances have been done in agriculture monitoring. It has been demonstrated in [EBROI] the quasi-linear relationship between the interferometric coherence and the height of a variety of crops, such as beet, wheat and potatoes. Besides, it has been observed, as it had been already shown in [ZV92], that the coherence decreases as the vegetation height increases due to the volumetric decorrelation, even for short vegetation.

\subsection{Polarimetric SAR Interferometry}

Most of works and investigations carried out upon retrieval of vegetation parameters conclude that a useful way to obtain more accurate estimates is to increase the number of independent observables of the input vector. This is achieved by polarimetric SAR interferometry (PolInSAR) [CP98], a technique which merges both the polarimetric and the interferometric information. The advantage of such approach is that it combines the potential of polarimetry to identify the physical properties of scatterers (scattering mechanisms) and the sensitivity of interferometry to the vertical structure of the medium.

Thus, PolInSAR retrieval algorithms are, in principle, more effective in separating the different scattering centers present in the vegetation cover. An interesting example of a vegetation cover model and its associated inversion scheme, specifically developed for POLINSAR, is given in [TMMv96, TS00]. It can be stated that the work by Treuhaft et al. [TSO0], which is indeed an extension of [TMMY96] by incorporating the polarimetric information, is one of the most outstanding works on this matter. In this model, the interferometric cross-products at different polarization channels were linked to the physical structure of various scenes: a random volume without ground (RV), a random volume over the ground (RVoG), and an oriented volume without ground (OV).

The model of a random volume over the ground was proposed to address the issue of forest height retrieval and biomass estimation. Based on this model, a formulation establishing the relationship between the PolInSAR observables and the biophysical parameters has been developed [PCO1, CP03]. An interesting feature of this inversion scheme is that it has associated a physics-based and simple interpretation. The loci of the coherence values corresponding to the model lie along a straight line on the complex plane. This line intersects the unit circle at the ground topographic height. Moreover, the thickness of the vegetation cover and the extinction coefficient are estimated finding the intersection point of the straight line and the curve associated with the model's volume coherence function [CP03]. The main application of this model is the retrieval of forest height. It has been used in [MPHO4a, MPHO4b] for forest biomass retrieval by means of allometric equations (i.e, an indirect estimation of biomass by firstly retrieving tree height). In these works it is demonstrated that this technique exhibits a good performance over dense forest stands at L-band, and the applicability over variable height forest areas is also analyzed. Nevertheless, it must be said that allometric 
equations still need from a more accurate definition to avoid estimation errors. Note that, indeed, inversion algorithms provide a mean height of the observed scene and not the height of every single tree. In addition, more advances must be done in order to decide the suitability of full or partial polarimetry for height and biomass estimation. In [DFCG 05] it is studied the relationship between biomass and $\mathrm{P}$-band intensity data at high incidence angles, which is of importance for spaceborne application sensors.

Also in $\left[\mathrm{GDFD}^{-} 05\right]$ promising results in forest height and extinction coefficient estimation have been reported at $\mathrm{X}$-band by using the random volume over ground model. Besides, a qualitative study of the effect of agricultural fields on the backscattering coefficients and the coherences of the linear basis is provided (see also [GDFD 06 ]). In particular, the characteristic behavior of the VV coherence over wheat, hay and tall grass is described, and it is stated that VV decorrelation relates directly to the orientated structure of the volume.

It can be stated that, to date, the most reliable application of PolInSAR is forest height and biomass estimation by using the RVoG model. Results give support to the idea of an L-Band spaceborne PolInSAR for global biomass mapping and monitoring. Nevertheless, further work must be carried out to quantify and minimize the effect of temporal decorrelation. Single-pass or short temporal baselines are required. As we will see, the need of such condition must be observed more strongly when dealing with agricultural crops.

When the vegetation is characterized by a well-defined preferred orientation, the RVoG model is not appropriate anymore, and additional electromagnetic effects must be accounted for. This is the case of many agricultural crops, which are also known as oriented volumes, such as rice or maize crops. These plants are mainly composed by vertically oriented stems with another smaller particles, such as leaves or small branches located at the upper layers. Maize crops were used to publish the first retrieval results about agricultural crops by means of PolInSAR [PRS ${ }^{-98}$ ]. In that case, no ground truth was available at that moment and the inversion technique was based only on phase differences.

The particular morphology of this type of vegetation introduces important differences in the scattering processes when comparing to isotropic or random mediums. Hence, the definition of inversion algorithms should observe the following:

- The propagation of the electromagnetic waves through an oriented volume is anisotropic because the extinction coefficients are polarization dependent. Consequently, there appears a new parameter to be estimated called differential extinction coefficient. This is what distinguishes an oriented from a random volume.

- The ground-stem dihedral response is usually dominant and, sometimes, it can mask any other backscatter contributions. As we will see in this thesis, this is indeed a necessary condition to measure at least one polarization channel with a ground return as high as possible in order to apply successfully the parameter retrieval.

- Compared to forest height retrieval, crop monitoring requires more accurate estimates due to the shorter height of this type of vegetation. Therefore, larger baselines than 
those for forest height retrieval need to be used in order to be more sensitive to the vertical structure of the medium.

- The fast growth cycle of the crops introduces a strong temporal decorrelation. As a result, only single-pass or short temporal baseline systems are suitable.

- Crops planted in a grid may show a backscatter intensity with a strong amplitude modulation as a function of the azimuth aspect angle and the geometry of the plantation grid [Ros98].

Regarding the orientation effects it must be also mentioned an alternative approach presented in [CPBO0]. Here, PolInSAR observables are also related to biophysical parameters but in this case the use of the optimized coherences [CP98] is justified in order to produce a considerable simplification of the formulation regarding the behaviour of an oriented volume. It must be noted that this study does not include the effect of ground.

As mentioned before, in [TSOO] the modelling of a random volume, a random volume over ground surface and an oriented volume are addressed, but it is not explicitly considered the effect of a ground plane under the oriented volume $(\mathrm{OVoG})$. This is a very important feature since the presence of ground will alter the backscattering response specially when dealing with agricultural crops due to the short volume height and the resulting high capability of wave penetration into it. Actually, it will be shown in this thesis that the ground-stem interaction, whose phase center is located theoretically at the ground interface [W\$LO8], will dominate the backscattering from many crops in a wide frequency range.

Current research activities are based on the vegetation models described above and are focused on the development of reliable inversion techniques able to account for the specific morphology of oriented volumes. In this sense, the parameter which introduces more uncertainty regarding its estimation process itself is the differential extinction coefficient. As it will be shown in this thesis, there is a lack of sensitivity with respect to this parameter, since large changes of it introduce small variations on the observables.

Furthermore, the physical interpretation of the extinction coefficient, and the information it provides, must be analyzed in the context of the particular plant type. Several current researches are pointed to that direction [Clo06\%, Clo06c, Clo07]). As a starting point, the classical water cloud model for vegetation, developed in 1978 by Atema and Ulaby [AU78] shows that extinction is related to plant water content, as a function of the depth and density of the cloud of particles. This model has been successfully applied at low frequencies (P and $\mathrm{L}$ band), but at higher frequencies it is not complete enough to model all the complex scattering phenomena present in vegetation media.

On the other hand, in [HCO5] the retrieval of crops height and extinction coefficient has been investigated, and a geometrical method to estimate this last parameter is suggested.

Regarding the general coherence optimization approach, it must be noted that, since it considers that the retrieved polarization states may be different for both images, some difficulties 
could appear in the interpretation of the results, since it would assume that the target can be described with two different polarization states, which is not the real case. Actually, for a monostatic case and when no temporal decorrelation affects the data acquisition, the optimized polarization states will be identical when the baseline takes a small value. Hence, it is possible to constrain the coherence optimization in order to retrieve the same polarization state for both images. In [GDO4, GDQB06] it is shown for a mature wheat canopy at $\mathrm{C}$ band that the constrained case can improve the performance of the unconstrained case in terms of accuracy of the separation of the scattering mechanisms in a layered target, i.e., it reduces the retrieved height distributions. The effect of the number of looks was also considered and it was demonstrated that the constrained optimization produces accurate results using around 10 looks, whereas the unconstrained optimization requires more than 30 looks to yield similar results. Another different constrained approach was also proposed in [CK05].

More recently, in [C10060] a new method for 3-D imaging of vegetation based on interferometry has been proposed. This approach, referred as coherence tomography, performs a reconstruction of the microwave scattering from vegetation along the vertical axis by means of a Legendre polynomials expansion of the interferometric coherence, and with an a priori knowledge of ground topography and volume height. The application of this technique has been tested in [Clo06c] with a simulated L-band PolInSAR data set for a Scots Pine forest, and in [CloO7] with wide-band fully polarimetric indoor measurements of a maize sample, where a dual-baseline configuration was used in order to increase the degree of the Legendre polynomial. The main contribution of such an approach lies in its capability for providing an insight into the scattering mechanisms and their polarization dependence inside the volume vegetation.

Additionally, a new research line has been initiated regarding the retrieval of snow and ice layer parameters by means of polarimetric SAR interferometry. Currently, investigations [PHNRO5, RNO5] are intended to explore the potential capabilities of such technique and to examine the effect of snow and ice volumes on wave propagation and scattering processes.

It must be noted that the scope of PolInSAR techniques goes beyond the characterization of natural media such as vegetation and snow covered surfaces. Another recent application consists in investigating the behaviour of urban scatterers and the evaluation of the potential information content of PolInSAR data, as it is shown in [GDFD 06$]$. Another example of such idea is reported in [SPHMO6], where multi-baseline polarimetric and interferometric SAR images acquired at L-band are used in order to identify and characterize urban point-like coherent scatterers by means of an analysis of interferometric and polarimetric parameters. The potential of polarimetry for orientation and dielectric constant retrieval is also addressed. In addition, it must be taken into account the potential of differential PolInSAR over DInSAR for urban areas applications. In principle, this technique could increase the density of permanent scatterers [FPROI] and would allow the use of new physical descriptors, such as rotation and twist.

One of the main drawbacks for the development and validation of new algorithms is the lack of fully-polarimetric data sets from air- and spaceborne sensors. In this sense, there 
is general agreement that the development of reliable retrieval techniques needs from the support of fully polarimetric sensors. Besides, the validation needs also from a very detailed ground truth and, similarly, a deeper understanding of what the radar is looking at as well as a more accurate knowledge of the important biophysical parameters from the point of view of ecology and agronomy.

Finally, it must be noted that polarimetric calibration issues [van90, Que94] are of great importance for PolInSAR processing in order to perform the calculation of correlation and interferometric terms without the negative effect of unknown source errors. 


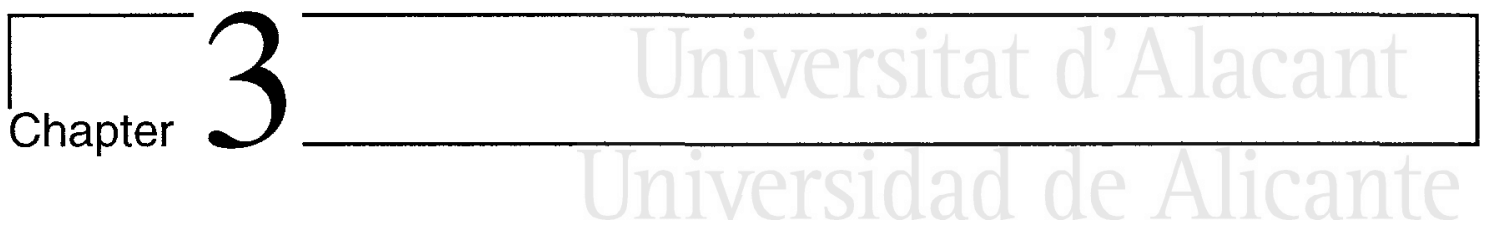

\section{Theory of Polarimetric SAR Interferometry}

This chapter is divided into four sections. The first one is intended to review the fundamentals on SAR imaging and SAR data statistics. The second section provides an approach to SAR interferometry and introduces the concepts of interferometric phase and interferometric coherence and, additionally, describes the main sources of coherece degradation. Next, the third part of this chapter is devoted to present the theory of SAR polarimetry, i.e. plane wave polarization concepts, scattering descriptors and target decomposition theory. Finally, the basic formulation on polarimetric SAR interferometry will be outlined.

\subsection{Synthetic Aperture Radar}

The aim of this section is to provide an overview of basic concepts on SAR imaging as well as an approach to the statistical characterization of SAR data.

\subsubsection{Fundamentals on SAR Imaging}

Synthetic Aperture Radar (SAR) [Ela88, Men91, CGM95] is a coherent active microwave imaging technique that generates high resolution images. The system geometry is depicted in Figure 3.1. A spaceborne or airborne SAR transmits and receives electromagnetic pulses along a linear trajectory which is called synthetic aperture. This dimension is referred as azimuth, cross-range or along-track coordinate ( $x$ dimension in Figure 3.1). The antenna is normally pointed perpendicularly to the flight direction in a side-looking fashion. The direction perpendicular to the flight is known as range or across-track dimension. The distance between the scatterer and the antenna is referred as slant-range, whereas its projection onto the ground is known as ground-range ( $y$ dimension in Figure 3.1). The area illuminated by the antenna beam is called swath. 


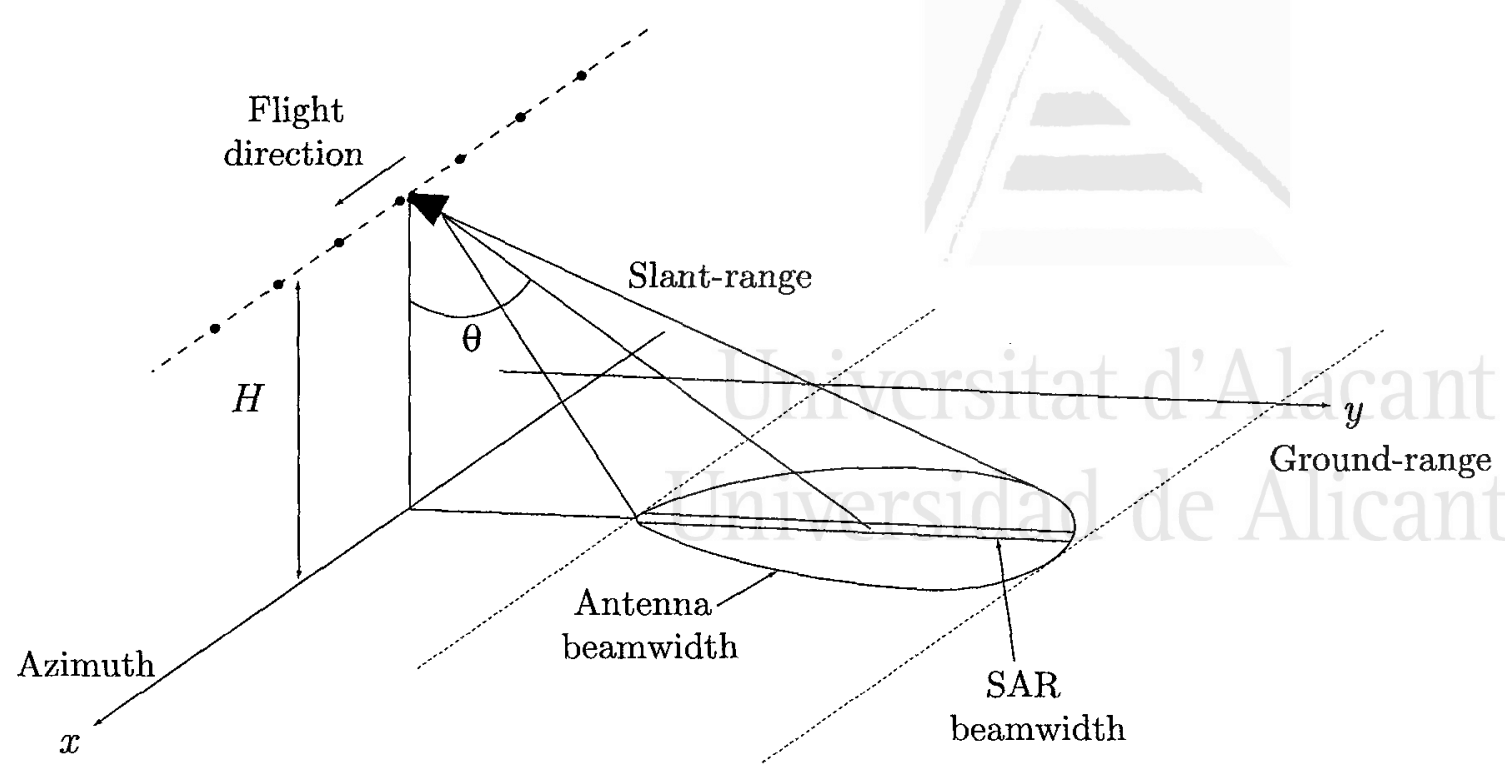

Figure 3.1: SAR imaging system geometry

The scattered fields received by the SAR system (see equation (3.7)), called raw data, are stored and usually arranged in a two dimensional matrix form. The transformation from the registered echoes to the scene's reflectivity map is carried out by a focusing process called image formation process, or, simply, SAR processing. This is generally divided into a range compression and an azimuth compression, producing the final SAR complex image where every pixel, or resolution cell, contains information of phase and amplitude.

The final image resolution is defined in terms of range resolution, $\delta_{r}$, and azimuth resolution, $\delta_{x}$, according to the two image coordinates.

Range processing is performed by correlating the returned echoes, which are attenuated and delayed versions of the transmitted signal, with a replica of the original signal. This technique is called matched filtering and provides a range resolution as a function of the transmitted signal bandwidth $W$ given by [Sko67] as

$$
\delta_{r}=\frac{c \tau}{2}=\frac{c}{2 W}
$$

where $c$ is the velocity of propagation and $\tau=1 / W$ is the transmitted pulse length. This relationship states that the shorter the pulse the finer range resolution. Nevertheless, in practical cases, there appear some hardware limitations in order to produce such short pulses maintaining also a high transmitted power. A way to overcome this limitation is to use chirp pulses. This consists in generating frequency modulated pulses which can be longer in time, but containing the required bandwidth.

Azimuth processing achieves a high resolution in the azimuth direction by means of the aperture synthesis. The basic idea is to simulate a phased array by positioning the antenna at different points along the synthetic aperture. The antenna beam illuminates the target several 
times as the platform flies along its path. The coherent combination of all received echoes at every antenna position produces an equivalent azimuth resolution of the order of the antenna size. The maximum theoretical azimuth resolution for a SAR system is

$$
\delta_{x}=\frac{D}{2}
$$

where $D$ is the antenna size. Note that the azimuth resolution of a SAR system does not depend on the distance between the sensor and the target, as it happens in a Real Aperture Radar (RAR) system. In the RAR case the antenna beamwidth $\Delta \theta$ controls the azimuth resolution which depends on the range position $R$ as

$$
\delta_{x_{R A R}} \approx \Delta \theta \cdot R=\frac{\lambda}{D} \cdot R
$$

Next, the basic equations that determine the SAR image formation process are outlined.

The SAR response from a point scatterer located at $\vec{r}^{\prime}\left(x^{\prime}, y^{\prime}, z^{\prime}\right)$ with a complex reflectivity $d \sigma_{s}$ can be expressed as

$$
d S=d \sigma_{s} \delta\left(x-x^{\prime}, y-y^{\prime}, z-z^{\prime}\right) h\left(x-x^{\prime}, r-r^{\prime}\right) e^{-j 2 k r^{\prime}}
$$

where $r^{\prime}$ is the distance between the sensor and the scatterer, the exponential term accounts for the propagation path of the wave, and $h(x, r)$ is the azimuth and range two dimensional impulse response of the SAR system. The $h(x, r)$ function can be approximated [ZV92] by a product of sinc functions for the slant-range and azimuth directions:

$$
h(x, r)=\operatorname{sinc}\left(\frac{x}{\delta_{x}}\right) \operatorname{sinc}\left(\frac{r}{\delta_{r}}\right)
$$

where $\operatorname{sinc}(x)=\sin (\pi x) /(\pi x)$.

In other words, the final SAR complex image is the result of a convolution of the scene's reflectivity with a low-pass filter whose characteristics are determined by the radar system and the observation geometry.

The imaging process of a distributed scatterer is analyzed by considering all the scattering contributions in a volume $V^{\prime}$. Two assumptions are made in order to simplify this process: 1) the scene is stationary during the echoes acquisition, and 2) the Born approximation is applied, which means that the total scattered field is made up by the superposition of the scattered fields from a collection of single scatterers inside the resolution cell, neglecting multiple scattering interactions.

Hence, the general expression for the SAR complex image is

$$
S(x, r)=\int_{V^{\prime}} \sigma_{s}\left(\vec{r}^{\prime}\right) e^{-j 2 \vec{k} \vec{r}^{\prime}} h\left(x-x^{\prime}, r-r^{\prime}\right) d V^{\prime}+n(x, r)
$$


where $\sigma_{s}\left(\vec{r}^{\prime}\right)=\sigma_{s}\left(x^{\prime}, y^{\prime}, z^{\prime}\right)$ is the complex reflectivity function of the distributed target and $n(x, r)$ is a noise contribution.

Assuming the SAR system operating in far-field conditions, the phase term in expression (3.6) can be approximated in order to consider a planar wave (see Figure 3.2). In this case, the SAR complex image becomes

$$
S(x, r) \approx e^{-j 2 k r_{r e f}} \int_{V^{\prime}} \sigma_{s}\left(\vec{r}^{\prime}\right) e^{-j 2 \vec{k} \vec{r}_{s}^{\prime}} h\left(x-x^{\prime}, r-r^{\prime}\right) d V^{\prime}+n(x, r)
$$

where $r_{r e f}$ indicates the distance to the center of the resolution cell and $\overrightarrow{r_{s}^{\prime}}$ represents the position vector of a single scatterer with respect to the center of the pixel.

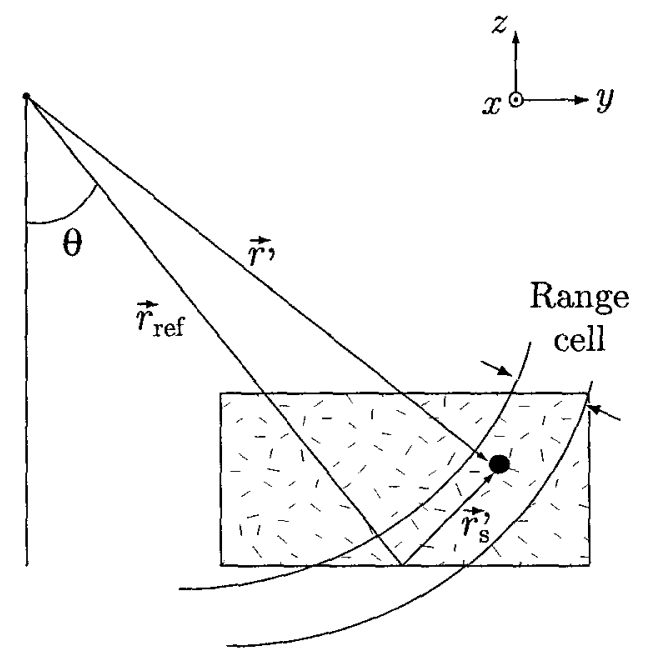

Figure 3.2: Distributed scatterer imaging geometry

Finally, since the information provided by the SAR complex image $S(x, r)$ is expressed in the azimuth-slant-range domain, a projection must be performed onto the ground-range plane $(x, y)$. This can be accomplished by means of interpolation. Consequently, the ground-range resolution becomes

$$
\delta_{y}=\frac{\delta_{r}}{\sin \theta}=\frac{c}{2 W \sin \theta}
$$

where $\theta$ is the incidence angle.

\subsubsection{SAR data statistics}

The interaction between electromagnetic waves and natural, as well as man-made, targets is a very complex process, and consequently, the retrieval of useful information from the scattered fields becomes an ardous task. 
In practice, it is impossible to describe completely the scene under study in terms of its electromagnetic response. Therefore, it is necessary to make use of statistical modelling of the scatterers as well as the scattered waves in order to extract some knowledge from the scene.

Most of targets can be characterized by two types of scattering processes: surface and volume scattering. In case of vegetation covers both contributions must be considered in order to describe the vertical structure in a more realistic way.

Surface scattering appears at the separation interface between two different media (air and ground), and hence, the scattered wave will be affected by the physical parameters of the surface, such as the height standard deviation, the surface correlation length, and the dielectric properties of the ground medium (i.e. the soil). On the other hand, the volume scattering takes place when the conditions of the wave propagation are modified by the structure of the medium, characterized by successive discontinuities in its dielectric properties. Depending on the way the scattering centers are arranged, the vegetation volume can be assumed as a random volume, an oriented volume, or any other arbitrary arrangement.

Despite this structural difference, radar remote sensing techniques are based on finding the average scattered field as a function of the statistical description of the scattering centers. This is a consequence of the inability of predicting the exact reflectivity value of a given pixel in a SAR image, which makes useless (in principle) the information provided by such a single pixel. In fact, since the image resolution cells are very large compared to the signal wavelength, an interference process among many elementary scattering centers occurs. These interferences can be constructive or destructive and, as a result, the SAR image quality is degraded by a granular noise which is called speckle. This phenomenon appears in all imaging techniques based on systems with a coherent illumination, such as ultrasound imaging or laser optics. Although speckle noise is not a random process but a true electromagnetic measurement, the complexity of the speckle component makes impossible to be predicted and, hence, it is considered as a noise-like process.

When dealing with a distributed target, it is useful to assume it as a collection of $N$ discrete scatterers, and consequently, the general expression for a complex SAR image given in (3.6) is applied in a discrete way, resulting in the form in (3.9):

$$
S(x, r)=\sum_{k=1}^{N} \sigma_{s}\left(x_{k}, r_{k}\right) h\left(x-x_{k}, r-r_{k}\right)
$$

where each scattering contribution, as well as its respective impulse response, is characterized as

$$
\begin{aligned}
\sigma_{s}\left(x_{k}, r_{k}\right) & =\sqrt{\sigma_{k}} e^{j \theta_{k}^{\prime}} \\
h\left(x-x_{k}, r-r_{k}\right) & =h_{k} e^{j \phi_{k}}
\end{aligned}
$$

In (3.10) $\sigma_{k}$ represents the radar cross section (RCS) [TKS85] of each elementary scatterer, $\theta_{k}^{\prime}$ is the associated phase, and $h_{k}$ and $\phi_{k}$ account for the amplitude and phase of each individual impulse response. 
It is useful to describe the total SAR reflectivity by means of a complex sum, which states that

$$
S(x, r) \rightarrow S(A, \theta)=A e^{j \theta}=\Re\{S\}+\Im\{S\}
$$

where $A$ is the total complex amplitude from a distributed target and $\theta$ its associated phase.

By using equations (3.10) and (3.12) it is possible to express

$$
S(A, \theta)=\sum_{k=1}^{N} h_{k} \sqrt{\sigma_{k}} e^{j\left(\theta_{k}^{\prime}+\phi_{k}\right)}=\sum_{k=1}^{N} a_{k} e^{j \theta_{k}}
$$

and the real and imaginary parts are

$$
\begin{aligned}
& \Re\{S\}=\sum_{k=1}^{N} a_{k} \cos \theta_{k} \\
& \Im\{S\}=\sum_{k=1}^{N} a_{k} \sin \theta_{k}
\end{aligned}
$$

The SAR reflectivity is represented on the complex plane in Figure 3.3.

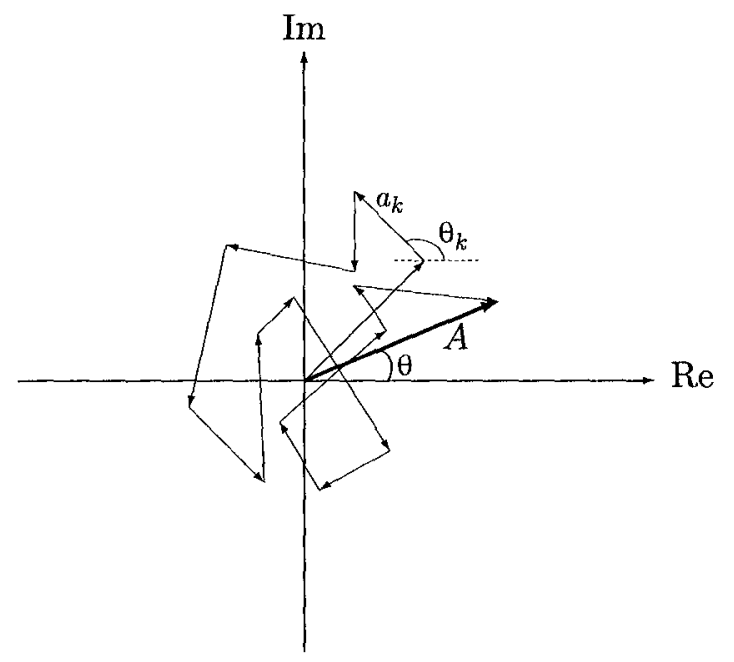

Figure 3.3: Total SAR reflectivity represented on the complex plane

The statistics of the elementary scattered signals in SAR images is described by a zeromean Gaussian probability density function (pdf), i.e., they are normally distributed. The 
behaviour of such electromagnetic fields is based on two assumptions that are valid provided that the dimensions of the resolution cell is larger than the system wavelength:

1) Amplitudes and phases of each single scatterer are statistically independent between them and from amplitudes and phases of all other elementary phasors. This means that the elementary scattering centers are uncorrelated and the strength of a given scattered wave keeps no relation to its phase.

2) The phases of elementary phasors are uniformly distributed in the the interval $[-\pi, \pi[$, since the resolution cell is larger than the wavelength.

In that case, and if the number of elementary scatterers, $N$, inside the resolution cell is large [Goo $76, B \$ 87]$, then, the real and imaginary parts of $S$ follow Gaussian distributions with zero mean and identical variances, as it is expressed in equations $(3.16)$ to $(3.19)$. The mean values are

$$
\begin{aligned}
& \langle\Re\{S\}\rangle=\sum_{k=1}^{N}\left\langle a_{k} \cos \theta_{k}\right\rangle=\sum_{k=1}^{N}\left\langle a_{k}\right\rangle \cdot\left\langle\cos \theta_{k}\right\rangle=0 \\
& \langle\Im\{S\}\rangle=\sum_{k=1}^{N}\left\langle a_{k} \sin \theta_{k}\right\rangle=\sum_{k=1}^{N}\left\langle a_{k}\right\rangle \cdot\left\langle\sin \theta_{k}\right\rangle=0
\end{aligned}
$$

and the variances values $\sigma^{2}$ are

$$
\begin{aligned}
& \left\langle\Re^{2}\{S\}\right\rangle=\sum_{k=1}^{N}\left\langle\left[a_{k} \cos \theta_{k}\right]^{2}\right\rangle=\sum_{k=1}^{N}\left\langle a_{k}^{2}\right\rangle \cdot\left\langle\cos ^{2} \theta_{k}\right\rangle=\frac{N}{2} \cdot\left\langle a_{k}^{2}\right\rangle \equiv \sigma^{2} \\
& \left\langle\Im^{2}\{S\}\right\rangle=\sum_{k=1}^{N}\left\langle\left[a_{k} \sin \theta_{k}\right]^{2}\right\rangle=\sum_{k=1}^{N}\left\langle a_{k}^{2}\right\rangle \cdot\left\langle\sin ^{2} \theta_{k}\right\rangle=\frac{N}{2} \cdot\left\langle a_{k}^{2}\right\rangle \equiv \sigma^{2}
\end{aligned}
$$

Moreover, the correlation between real and imaginary parts of $S$ is zero:

$$
\langle\Re\{S\} \cdot \Im\{S\}\rangle=\sum_{k=1}^{N} \sum_{l=1}^{N}\left\langle a_{k} a_{l}\right\rangle\left\langle\cos \theta_{k} \sin \theta_{l}\right\rangle=0
$$

From the previous considerations, the pdf's of the real and imaginary parts of $S=s_{r}+j s_{i}$ are respectively, 


$$
\begin{aligned}
& p_{s_{r}}\left(s_{r}\right)=\frac{1}{\sqrt{2 \pi \sigma^{2}}} \cdot e^{\frac{-s_{r}^{2}}{2 \sigma^{2}}} \\
& p_{s_{i}}\left(s_{i}\right)=\frac{1}{\sqrt{2 \pi \sigma^{2}}} \cdot e^{\frac{-s_{i}^{2}}{2 \sigma^{2}}}
\end{aligned}
$$

where $\left.s_{r}, s_{i} \in\right]-\infty, \infty[$ and $\sigma$ is the standard deviation.

The pdf's of amplitude and phase of the complex reflectivity $S(A, \theta)=A e^{j \theta}$ can be derived from equations (3.21) and (3.22) as

$$
\begin{aligned}
p_{A}(A) & =\frac{A}{\sigma^{2}} \cdot e^{\frac{-A^{2}}{2 \sigma^{2}}} \\
p_{\theta}(\theta) & =\frac{1}{2 \pi}
\end{aligned}
$$

where $A \in[0, \infty[$ and $\theta \in[-\pi, \pi[$, and the joint pdf is expressed as

$$
p_{A, \theta}(A, \theta)=\frac{A}{\sqrt{2 \pi \sigma^{2}}} \cdot e^{\frac{-A^{2}}{2 \sigma^{2}}}
$$

The pdf $p_{A}(A)$ in (3.23) is a Rayleigh distribution whose mean and variance are, respectively,

$$
\begin{aligned}
\langle A\rangle & =\sigma \sqrt{\pi / 2} \\
\left\langle A^{2}\right\rangle & =(2-(\pi / 2)) \sigma^{2}
\end{aligned}
$$

Another magnitude of interest is the intensity of the SAR image $I=A^{2}$, which is described by an exponential distribution

$$
p_{I}(I)=\frac{1}{2 \sigma^{2}} \cdot e^{\frac{-I}{2 \sigma^{2}}}
$$

whose mean and variance values are

$$
\langle I\rangle=\left\langle I^{2}\right\rangle=2 \sigma^{2}
$$

In Figure 3.4 the distributions for the amplitude, intensity and phase of a complex SAR image are shown.

30 


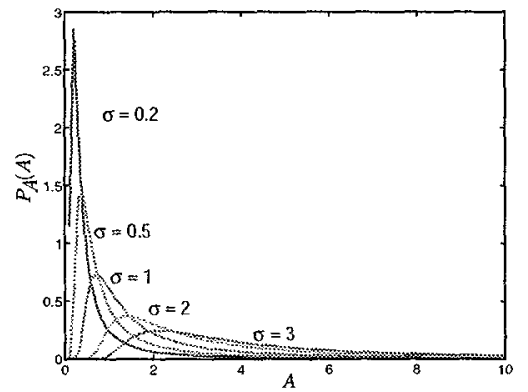

a)

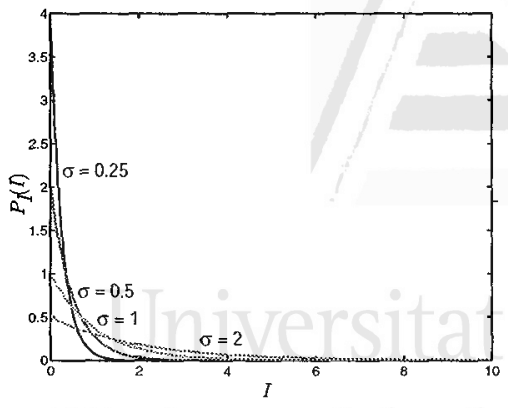

b)

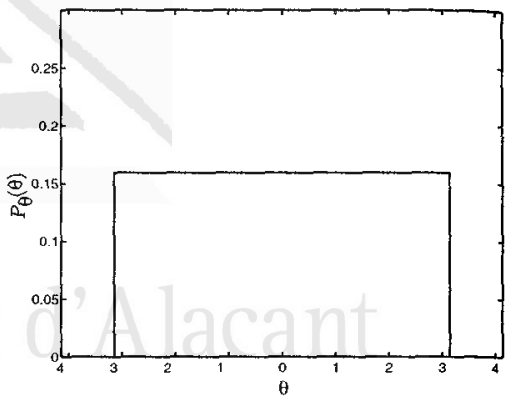

c)

Figure 3.4: Probability density functions for a complex SAR image: a) Amplitude; b) Intensity; c) Phase.

It is possible to reduce the standard deviation of the distributions by combining several independent measurements, also known as looks. In practical applications with SAR images, it can be performed by averaging a number of adjacent pixels within a homogeneous region. This averaging must be done by using the intensity magnitude. As a consequence, the variance of the estimations is reduced by $L$ times, being $L$ the number of looks. In this case, the multi-look SAR intensity distribution is expressed as

$$
p_{I_{L}}\left(I_{L}\right)=\frac{1}{\Gamma(L)} \cdot\left(\frac{L}{\sigma}\right)^{L} \cdot I_{L}^{L-1} e^{-\frac{L I_{L}}{\sigma}}
$$

It is important to note that the Gaussian scattering model is not valid for high resolution SAR imaging, as a consequence of the small number of scatterers that contribute to the total field inside the resolution cell, as it happens in urban areas [SHLPOS].

As mentioned in the previous lines, the speckle effect is characterized as a noise-like process due to the difficulty to be predicted, although, indeed, it is a deterministic contribution. Therefore, from expression (3.28) and considering $I=2 \sigma^{2} z$, the speckle model is defined as

$$
p_{z}(z)=e^{-z}
$$

where $z \in[0, \infty[$. It must be pointed out that this speckle model is only valid for amplitude or intensity SAR image magnitudes.

The Gaussian scattering model for a SAR image can be extended when linear combinations of different channels are employed. In this case, a multivariate Gaussian distribution is used [OQ98], which is totally described by its covariance matrix $C$ defined as the expected value of the Hermitian products between the considered channels. By using the expression in $(3.13)$ for a complex SAR image, the covariance between two channels $p$ and $q$ can be 
expressed as

$$
C_{p q}=\left\langle S^{p} S^{q *}\right\rangle=\left\langle\sum_{k=1}^{N_{p}} a_{k}^{p} e^{j \theta_{k}^{p}}\right\rangle \cdot\left\langle\sum_{l=1}^{N_{q}} a_{l}^{q *} e^{-j \theta_{l}^{q}}\right\rangle
$$

where $N_{p}$ and $N_{q}$ are the number of scatterers for channels $p$ and $q$, respectively. Assuming that both channels represent the same image (they have been taken and co-registered simultaneously), then $N_{p}=N_{q}=N$, and hence

$$
C_{p q}=\left\langle S^{p} S^{q *}\right\rangle=\left\langle\sum_{k=1}^{N} a_{k}^{p} a_{k}^{q *}\right\rangle+\left\langle\sum \sum_{p \neq q} a_{k}^{p} a_{l}^{q *} e^{j\left(\theta_{k}^{p}-\theta_{l}^{q}\right)}\right\rangle
$$

From expression (3.33) and considering that amplitude and phase values are statistically independent, it can be rewritten as:

$$
C_{p q}=\left\langle S^{p} S^{q *}\right\rangle=\left\langle\sum_{k=1}^{N} a_{k}^{p} a_{k}^{q *}\right\rangle+\sum \sum_{p \neq q}\left\langle a_{k}^{p} a_{l}^{q *}\right\rangle\left\langle e^{j\left(\theta_{k}^{p}-\theta_{l}^{q}\right)}\right\rangle
$$

The first term in expression (3.34) depends only on the properties of individual scatterers for different channels, and the second term describes the interaction between different pairs of scatterers. Assuming that the dimensions of the resolution cell are large when compared to the wavelength, the second term will be zero since the phase of the exponential term is uniformly distributed in $[-\pi, \pi[$, and therefore the expected value is null.

The generalization of the Gaussian scattering model to multi-look SAR imagery is given by the multivariate Gaussian distribution defined as [WW04, LHMM94, TBQ95]

$$
P_{\vec{S}}(\vec{S})=\frac{1}{\pi^{2}|\mathbf{C}|} \cdot e^{-\vec{S}^{\star} \mathbf{C}^{-1} \vec{S}}
$$

where $\mathbf{C}$, assuming two channels for simplicity, is given by

$$
\mathbf{C}=\left[\begin{array}{cc}
\sigma_{p}^{o} & \sqrt{\sigma_{p}^{o} \sigma_{q}^{o}} \rho \\
\sqrt{\sigma_{p}^{o} \sigma_{q}^{o}} \rho^{*} & \sigma_{q}^{o}
\end{array}\right]
$$

where $\sigma_{p, q}^{o}$ are the backscattering coefficients for channels $p$ and $q$, defined as $\sigma_{p, q}^{o}=\left\langle\left|S^{p, q}\right|^{2}\right\rangle$, and $\rho$ is the correlation coefficient between both channels, given by

$$
\rho=\frac{\left\langle S^{p}\left(S^{q}\right)^{*}\right\rangle}{\sqrt{\sigma_{p}^{o} \sigma_{q}^{o}}}=|\rho| e^{j \phi_{0}}
$$


Now, the complex reflectivity $S\left(A_{i}, \theta_{i}\right)=A_{i} e^{j \theta_{i}}$, with $i=p, q$, is substituted in the expression for the backscattering coefficient, and therefore from expressions (3.35) and (3.36) it can be obtained the single-look distributions for the amplitude and phase of the Hermitian product of a pair of SAR images as [TBQ95]

$$
\begin{aligned}
P_{\phi}(\phi) & =\frac{\left(1-|\rho|^{2}\right)}{2 \pi} \cdot\left(\frac{\beta\left(\frac{\pi}{2}+\arcsin (\beta)\right)}{\left(1-\beta^{2}\right)^{3 / 2}}+\frac{1}{1-\beta^{2}}\right) \\
P_{z}(z) & =\frac{4 z}{\sigma_{p} \sigma_{q}\left(1-|\rho|^{2}\right)} \cdot I_{0}\left(\frac{2|\rho| z \mid}{\sqrt{\sigma_{p} \sigma_{q}}\left(1-|\rho|^{2}\right)}\right) \cdot K_{0}\left(\frac{02 z] 1 C}{\sqrt{\sigma_{p} \sigma_{q}}\left(1-|\rho|^{2}\right)}\right)
\end{aligned}
$$

where $\phi=\theta_{p}-\theta_{q} ; z=A_{p} A_{q} ; \beta=|\rho| \cos \left(\phi-\phi_{0}\right) ; I_{0}(\cdot)$ and $K_{0}(\cdot)$ are the Bessel functions of first and third kind, respectively. Figure 3.5 shows the phase difference distribution, which is important when applying SAR interferometry to infer the vertical height of targets.

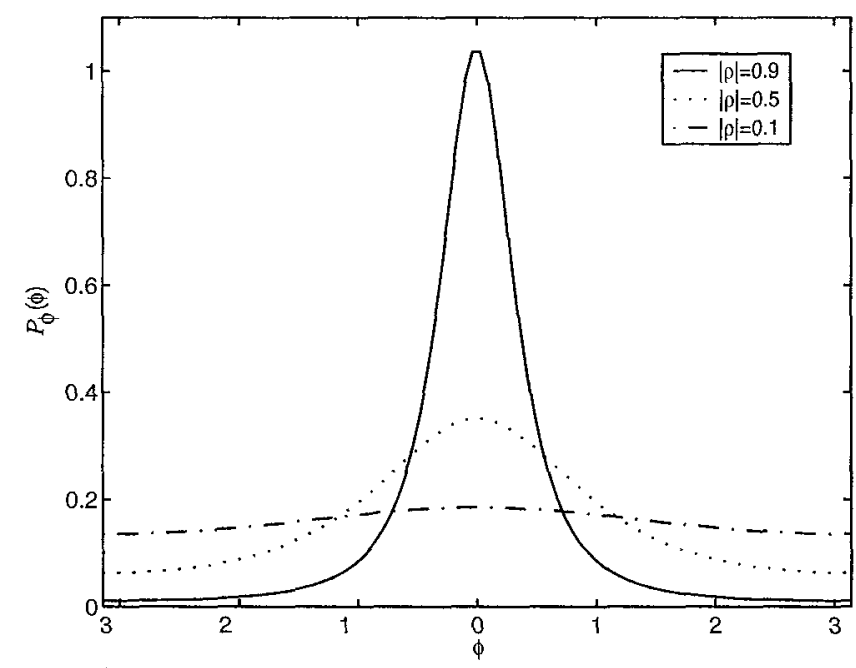

Figure 3.5: Single-look distribution for the phase of the Hermitian product of a pair of SAR images. Effect of the magnitude of the correlation coefficient $|\rho|$. Plots have been obtained with $\phi_{0}=0 \mathrm{rad}$

As stated before, in practical applications it is usual to average several looks of the SAR image in order to reduce the variance of the measurements. Hence, the multi-look covariance matrix $\mathrm{C}$ is given by the maximum likelihood estimator as [RM92]

$$
C_{p q}=\frac{1}{L} \sum_{n=1}^{L} S_{n}^{p} S_{n}^{q *}
$$

where $L$ is the number of averaged independent samples. Therefore, the multi-look distribution for the phase is given by [TBQ95] 


$$
\begin{aligned}
P_{\phi_{L}}\left(\phi_{L}\right) & =\frac{\left(1-|\rho|^{2}\right)^{L}}{2 \pi} \cdot\left[\frac { ( 2 L - 2 ) ! } { [ ( L - 1 ) ! ] ^ { 2 } 2 ^ { 2 ( L - 1 ) } } \cdot \left(\frac{(2 L-1) \beta}{\left(1-\beta^{2}\right)^{L+1 / 2}} \cdot(\pi / 2+\arcsin \beta)+\right.\right. \\
& \left.\left.+\frac{1}{\left(1-\beta^{2}\right)^{L}}\right)+\frac{1}{2(L-1)} \sum_{n=0}^{L-2} \frac{\Gamma(L-1 / 2)}{\Gamma(L-1 / 2-n)} \cdot \frac{\Gamma(L-1-n)}{\Gamma(L-1)} \cdot \frac{1+(2 n+1) \beta^{2}}{\left(1-\beta^{2}\right)^{n+2}}\right]
\end{aligned}
$$

where $\Gamma(\cdot)$ is the gamma function. Note that if $L=1$, expression (3.41) equals the expression for the single-look case. Some plots of $(3.41)$ for different number of looks are shown in Figure 3.6 , where it can be seen that an increase of the number of looks results in a narrower distribution, i.e., an increase of the likelihood of the measured phase.

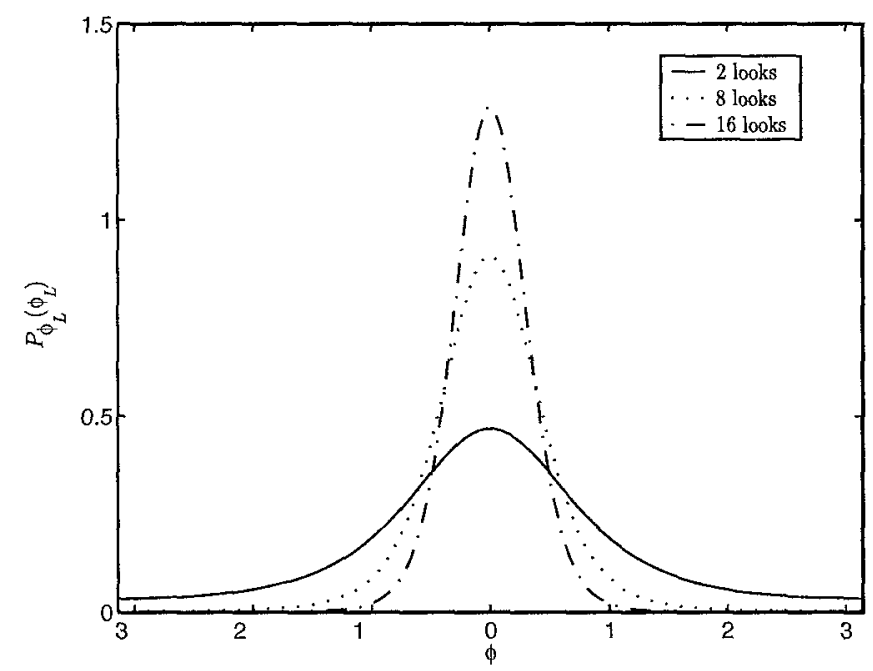

Figure 3.6: Multi-look distribution for the phase of the Hermitian product of a pair of SAR images for different number of looks. Plots have been obtained with $\phi_{0}=0 \mathrm{rad}$ and $|\rho|=0.5$

The maximum likelihood estimator for the multi-look correlation value is given by [0998]

$$
\rho=\frac{\sum_{k=1}^{L} S_{k}^{p} S_{k}^{q *}}{\sqrt{\sum_{k=1}^{L}\left|S_{k}^{p}\right|^{2}\left|S_{k}^{q}\right|^{2}}}
$$

When working with multichannel SAR data, for example in interferometry and polarimetry, the dimensionality of the observables space is increased. This can be used for improving the correlation estimates but the estimation process becomes more complex [LM03]. 


\subsection{SAR interferometry}

SAR interferometry (InSAR) exploits the phase difference between two complex SAR images that have been acquired from slightly different positions and/or at different moments. This technique was firstly applied for DEM (Digital Elevation Model) generation and for detecting small changes or deformations in the ground surface (differential interferometry) [ZvH87, GGZ89, MR93]. Nevertheless, the capability of this technique to determine the vertical structure of distributed targets enables its application in the retrieval of biophysical parameters from natural covers. This section is aimed to provide the basic concepts aboul InSAR. The geometry of the problem will be described, and this will lead to the definition ot the interferometric phase and the interferometric coherence. The former is the key concep used to infer the height corresponding to a resolution cell, and the later is interpreted as a measure of the variance of the interferometric phase, i.e., the quality of the height estimation. The last part of this Section is devoted to present the main sources of decorrelation which induce coherence degradation.

\subsubsection{InSAR geometry}

A general InSAR geometry is depicted in Figure 3.7. Two antennas $A 1$ and $A 2$ fly on parallel tracks (orthogonal to the plane of the page) and image a scene from slightly different look angles, $\theta_{1}$ and $\theta_{2}$. The separation between both antennas is called baseline, $B$, which maintains an angle $\alpha$ with respect to the horizontal. The path length difference is $\Delta r=r_{2}-r_{1}$, which will be used later on to estimate the height of each resolution cell.

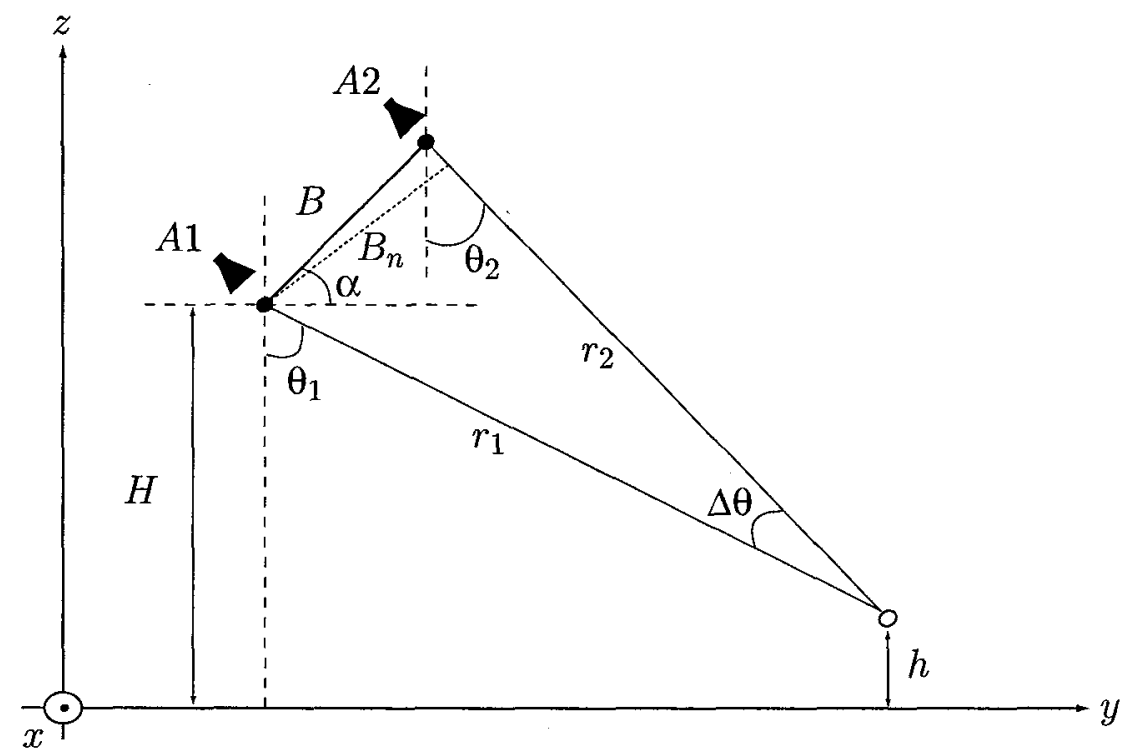

Figure 3.7: Geometry of an interferometric SAR system 
With respect to the acquisition time, two configurations are possible:

- Single-pass interferometry: Both complex SAR images are acquired simultaneously.

- Repeat-pass interferometry. A single receiving antenna is used and each image is acquired at different orbit passes or flights.

SAR interferometry with satellite sensors is currently implemented in a repeat-pass mode since it is difficult to place two antennas on the same platform. This fact limits importantly the retrieval of information from the interferogram, since there appear changes in the scene due to the time interval between both acquisitions. Nevertheless, it must be pointed out that this problem will be overcome in the next future when TanDEM-X mission and Radarsat-2 and Radarsat-3, operating in tandem mission, will provide single-pass interferometric data in a continuous way for the first time.

Note that the experimental data used throughout this thesis were acquired in a repeat-pass interferometric mode in the European Microwave Signature Laboratory (EMSL), at JRCIspra, Italy. Nevertheless, they can be considered as single-pass interferometric data because of the controlled conditions of the measurements.

\subsubsection{The interferometric phase}

As stated in the previous Section, the phase of a SAR image is uniformly distributed over all the resolution cells due to the number of the wave cycles and speckle noise and, consequently, it is discarded since no information is recovered. Nevertheless, SAR interferometry exploits the phase difference between two images in order to relate it to the vertical structure of the target.

If the geometry depicted in Figure 3.7 is considered, the recorded signals are:

$$
\begin{aligned}
& s_{1}=s\left(x, r_{1}\right)=\sigma\left(x, r_{1}\right) e^{-j 2 k r_{1}} \\
& s_{2}=s\left(x, r_{1}+\Delta r\right)=\sigma\left(x, r_{1}+\Delta r\right) e^{-j 2 k\left(r_{1}+\Delta r\right)}
\end{aligned}
$$

where $x$ represents the azimuth coordinate, $\sigma\left(x, r_{i}\right)$ is the complex reflectivity of the point scatterer, and $\Delta r$ is the path length difference between both acquisitions.

Assuming that the scattering properties are the same in both images $\left(\sigma\left(x, r_{1}\right)=\sigma\left(x, r_{1}+\right.\right.$ $\Delta r)$ ), the interferometric phase is calculated as the argument of the Hermitian product of both complex signals:

$$
\phi=\left\langle s_{1} \cdot s_{2}^{*}\right\rangle=\frac{4 \pi}{\lambda} \Delta r
$$


Therefore, after some basic trigonometric equations, the path length difference is related to the geometry as:

$$
\sin (\alpha-\theta)=\frac{\left(r_{1}+\Delta r\right)^{2}-r_{1}^{2}-B^{2}}{2 r_{1} B}
$$

where $\theta=\left(\theta_{1}+\theta_{2}\right) / 2$ represents the average incidence angle. As a result, the local height of a point scatterer can be estimated as:

$$
h=H-r_{1} \cdot \cos \theta
$$

Although equations (3.47) and (3.48) express a direct relationship between geometry and phase difference, it is necessary to consider the displacement of scatterers on the groundrange dimension in order to maintain proportionality between the interferometric phase and the height of such scatterers. In other words, an interferometer will measure a non zero phase, and consequently a non zero height, even when the scatterer is located at a $0 \mathrm{~m}$ height.

The ground range dependence can be studied by expressing the path length difference $\Delta r=$ $r_{2}-r_{1}$ in the interferometric phase (3.46) as a function of the $(y, z)$ scatterer coordinates, considering the distance from the antennas to the corresponding reference point on ground. Figure 3.8 shows the geometry for the antenna $A_{1}$.

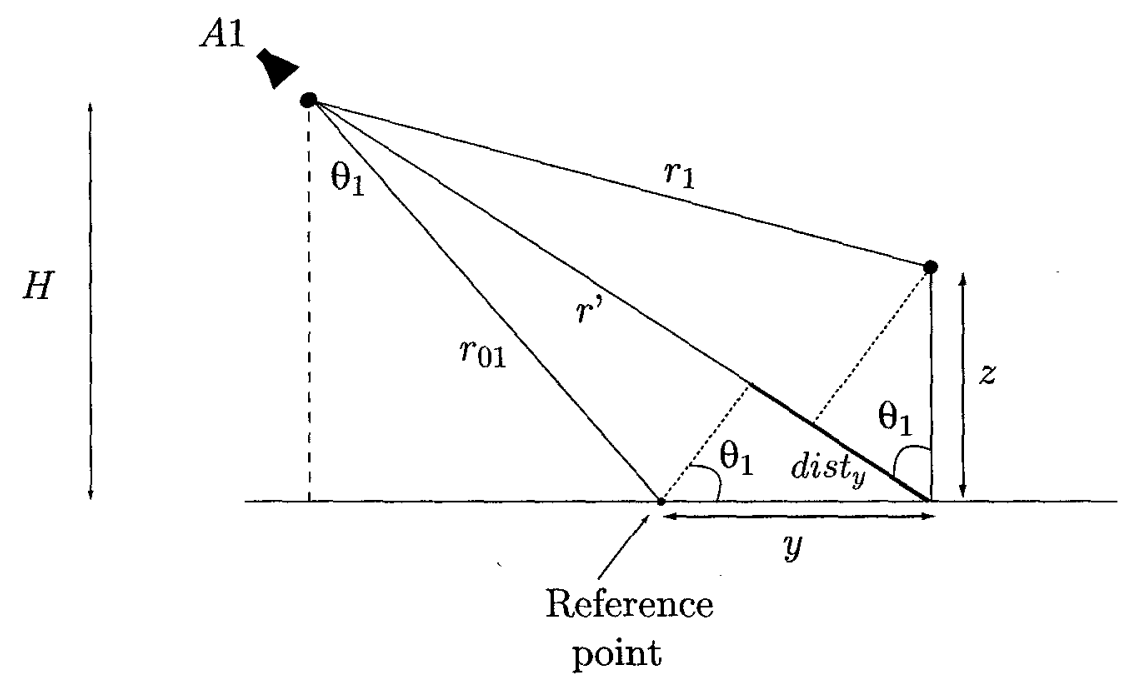

Figure 3.8: Calculation of $\Delta r=r_{1}-r_{2}$ for an interferometric SAR system

The slant-range reference point on ground for antenna $A_{1}$ is $r_{01}$, which is located at a distance $y$ from the horizontal location of scatterer at $(y, z)$. The range $r^{\prime}$ can be estimated as:

$$
r^{\prime} \approx r_{01}+\text { dist }_{y}=r_{01}+y \sin \theta_{1}
$$

On the other hand, the antenna-target distance can be approximated as:

$$
r_{1} \approx r^{\prime}-z \cos \theta_{1}=r_{01}+y \sin \theta_{1}-z \cos \theta_{1}
$$


Appplying the same expressions for the antenna $A_{2}$, the path length difference yields:

$$
\begin{aligned}
\Delta r=r_{2}-r_{1} & =\left(r_{02}+y \sin \theta_{2}-z \cos \theta_{2}\right)-\left(r_{01}+y \sin \theta_{1}-z \cos \theta_{1}\right)= \\
& =\Delta r_{0}+y\left(\sin \theta_{2}-\sin \theta_{1}\right)+z\left(\cos \theta_{1}-\cos \theta_{2}\right)
\end{aligned}
$$

where the term $\Delta r_{0}=r_{02}-r_{01}$ corresponds to the so called flat earth component which can be easily eliminated. Once this contribution has been removed, the interferometric phase yields:

$$
\phi \approx \frac{4 \pi}{\lambda} \cdot\left[y\left(\sin \theta_{2}-\sin \theta_{1}\right)+z\left(\cos \theta_{1}-\cos \theta_{2}\right)\right]
$$

Expression (3.52) is made up of two terms which have to do with the ground-range location $y$ of the scatterer and its vertical position $z$. They will be further discussed in Section 3.2.3.1.

The next step is to eliminate the inherent ambiguity present in the recorded phase which is modulo $2 \pi$. The final phase estimate that will be used in the height retrieval is expressed as:

$$
\phi_{u n w}=\phi+2 \pi N
$$

which $N$ is an integer to be estimated by means of a procedure known as phase unwrapping [ZL98].

In practical situations, most of natural targets must be seen as distributed targets which, as we have done previously, can be approximated by a collection of $N$ point scatterers contributing to the total scattering response from a single resolution cell. Hence the interferometric phase is now derived as:

$$
\left\langle s_{1} \cdot s_{2}^{*}\right\rangle=\left\langle\sum_{k=1}^{N} \sigma_{k} e^{-j 2 k r_{k}}\right\rangle \cdot\left\langle\sum_{l=1}^{N} \sigma_{l}^{*} e^{j 2 k r_{l}}\right\rangle
$$

Considering again the assumptions made in Section 3.1.2 regarding the statistical independence of scatterers and the large size of the resolution cell in terms of the wavelength, equation $(3.55)$ is rewritten as

$$
\left\langle s_{1} \cdot s_{2}^{*}\right\rangle=\sum_{k=1}^{N}\left\langle\left|\sigma_{k}\right|^{2} e^{j 2 k \Delta r_{k}}\right\rangle
$$

The averaged contributions from all scatterers will determine the interferometric phase used to infer the vertical location of the scattering phase center of each resolution cell.

\subsubsection{The interferometric coherence}

The generation of a DEM relies on the interferometric phase. As a consequence, the quality of the final DEM will be conditioned by the quality of the phase difference between both SAR images. It is required that the variations in phase terms are due only to the topography of the 
scene. The parameter that measures the quality of the interferogram is called interferometric coherence [JB94], and it is defined as the modulus of the normalized cross-correlation of the complex signals, $s_{1}$ and $s_{2}$, measured by both antennas from each resolution cell in the scene, and computed as:

$$
\gamma=\frac{\left\langle s_{1} \cdot s_{2}^{*}\right\rangle}{\sqrt{\left\langle\left|s_{1}\right|^{2}\right\rangle\left\langle\left|s_{2}\right|^{2}\right\rangle}}
$$

The expected value operator $\langle\cdot\rangle$ is substituted by a spatial averaging for practical purposes. The number of samples to be taken in the averaging is a trade-off between statistical criteria and the homogeneity of the image inside the block used for the averaging.

The absolute value of (3.56), referred also as coherence, ranges from zero to one. A zero value means that both images are totally uncorrelated and no information can be extracted from the interferogram since the phase is noisy. On the other hand, a coherence close to one identifies a high quality, noise-free interferogram, and an accurate estimation of height is possible.

The accuracy of the final topographic maps can be expressed by means of the Cramer-Rao bound for the standard deviation of the estimated height, $\sigma_{h}$, which is related to the standard deviation of the interferometric phase, $\sigma_{\phi}$, as [RMO2]:

$$
\sigma_{h}=\frac{\lambda r \tan \theta}{4 \pi B} \sigma_{\phi}
$$

where $\lambda$ is the carrier wavelength, $r$ is the range distance between the radar and the target, $\theta$ is the mean incidence angle, and $B$ is the baseline. The expression of the standard deviation of the interferometric phase as a function of the number of looks $N_{L}$, i.e. the number of averaged resolution cells, and the interferometric coherence is:

$$
\sigma_{\phi}=\frac{1}{2 \sqrt{N_{L}}} \frac{\sqrt{1-|\gamma|^{2}}}{|\gamma|}
$$

Note that increasing the number of looks reduces the statistical fluctuations of the phase and, hence, the uncertainty of the inferred height. However, this produces a lower spatial resolution. On the other hand, a coherence degradation produces a higher phase variance which induces a larger height error.

\subsubsection{Sources of coherence degradation}

The total coherence can be separated into several contributions [ZV92] which are, indeed, sources of coherence degradation, also known as interferometric decorrelation:

$$
|\gamma|=\gamma_{n} \cdot \gamma_{t} \cdot \gamma_{B} \cdot \gamma_{v}
$$

where $\gamma_{n}$ represents the decorrelation due to the finite signal-to-noise ratio (SNR) value produced by the system thermal noise; $\gamma_{t}$ is the temporal decorrelation which accounts for 
changes in the scene between two acquisitions; $\gamma_{B}$ is the baseline decorrelation which describes the effect of different imaging geometries, i.e. two different incidence angles; $\gamma_{v}$ is the volumetric decorrelation and accounts for the height distribution of scatterers which difficults the determination of the interferometric phase center inside the resolution cell.

Next, a brief description of each decorrelation source is provided.

- Thermal noise decorrelation

If the same SNR is assumed for both images, this contribution is given by [ $2 \times 92]$

$$
\gamma_{n}=\frac{1}{1+S N R^{-1}}
$$

At first sight, this decorrelation source becomes important only when a very low backscattering is present. However, the coherence degradation due to noise should be evaluated depending on the application [RM92]. For example, if the interferogram is generated with a short baseline, even a $10 \mathrm{~dB}$ signal-to-noise ratio will degrade completely the system performance due to the low sensitivity in the phase-to-height conversion.

\section{- Temporal decorrelation}

It is assumed that scatterers reflectivity remains unchanged for both images in order to relate the interferometric phase to the scatterer height. However, if a repeat-pass interferometer is used, the scattering centers reflectivity may be modified. This is a usual situation when vegetated areas are imaged, since the vegetation water content or the soil moisture are changing features, and the wind may produce a movement in leaves and branches. In fact, this coherence degradation has been exploited in classification algorithms in vegetated and forested areas [WWS5].

\section{- Baseline decorrelation}

This source of decorrelation is caused by the spatial separation of both antennas. The different look angles causes a spectral shifting in the reflectivity spectrum of both images, i.e. the same spectral component in the first image at $f_{1}$ will be found in the second image at a frequency $f_{2}$, which makes both spectra not to be coincident [GMP $\mathrm{C4}^{+9}$. This effect can be observed in expression (3.52) where the interferometric phase depends on ground-range and vertical coordinates, $y$ and $z$, respectively.

The baseline decorrelation will be given by those parts of spectra in the $k_{y}$ dimension that do not overlap. The frequency shift $\Delta f$ between both images for the monostatic case is [GMP+94]:

$$
\Delta f=\frac{f B_{n}}{r_{0} \tan (\theta-\alpha)}
$$

where $f$ is the carrier frequency, $r_{0}$ is the distance between antennas and ground, $B_{n}$ is the effective baseline, $\theta$ is the mean incidence angle and $\alpha$ the local slope of the surface. The corresponding expression for the bistatic case is half the monostatic one. 
In the case of pure surface scattering, this decorrelation can be reduced by means of a frequency shifting in the second SAR image or, alternatively, by applying a spectral filtering in order to remove the non-common parts of both spectra [PR93]. It is accomplished by satisfying the following relationship which removes the dependence on the $y$ dimension:

$$
f_{1} \sin \theta_{1}=f_{2} \sin \theta_{2} \rightarrow f_{2}=f_{1} \frac{\sin \theta_{1}}{\sin \theta_{2}}
$$

On the other hand, a vertical distribution of scatterers inside a resolution cell will produce a spectral decorrelation in the vertical wavenumber domain dimension, $k_{z}$, which will not be possible to remove. This effect is called volume decorrelation.

- Volume decorrelation

As in the case of baseline decorrelation, this source of coherence degradation appears as a consequence of using two different look angles to view the same scene. When the imaged scene is made up of a collection of scattering centers in a vertical distribution inside a resolution cell there appears an uncertainty on the interferometric phase. This structure of the target induces a spectral displacement in the $z$ dimension which is accounted for by means of the effective propagation constant $k_{z}$ which is obtained from expression (3.52) after applying the condition given by (3.62):

$$
k_{z}=\frac{4 \pi}{c} f\left(\cos \theta_{1}-\frac{\sin \theta_{1}}{\sin \theta_{2}} \cos \theta_{2}\right)
$$

Now, if we assume that $\theta_{2}-\theta_{1}=\Delta \theta$ is close to zero, the following approximations can be used:

$$
\begin{aligned}
& \sin \theta_{1}=\sin \left(\theta_{2}-\Delta \theta\right) \approx \sin \theta_{2}-\Delta \theta \cos \theta_{2} \\
& \cos \theta_{1}=\cos \left(\theta_{2}-\Delta \theta\right) \approx \cos \theta_{2}+\Delta \theta \sin \theta_{2}
\end{aligned}
$$

Therefore, substituting into (3.63), the effective vertical propagation constant yields:

$$
k_{z} \approx \frac{4 \pi}{c} f \frac{\Delta \theta}{\sin \theta_{2}}=\frac{4 \pi}{c} f \frac{\Delta \theta}{\sin \theta}
$$

with $\theta=\left(\theta_{1}+\theta_{2}\right) / 2$.

In principle, volume decorrelation is an undesirable effect which can not be eliminated, leading to a coherence degradation that will be very significant in vegetated areas. Nevertheless, this is indeed the effect that allows the retrieval of the vertical structure of the above ground vegetation. A non zero effective propagation constant is caused by the volumetric decorrelation introduced by the vegetation layer, whose vertical extent can be estimated from the interferometric phase $\phi$ as:

$$
h=\frac{\phi}{k_{z}}
$$




\subsection{Radar Polarimetry}

Radar polarimetry exploits the relationship between wave polarization and the complex structure of the target in order to retrieve physical parameters from the scene. This is accomplished by recording the scattered echoes from the target at different polarization states.

Polarimetry was first applied in 1941 by R. Clark Jones for the characterization of optical systems. The first work in radar polarimetry is attributed to G. Sinclair [Sins0] who introduced the concept of scattering matrix. This is a $2 \times 2$ complex matrix whose entries are the measured reflectivities for the four combinations of transmitted-received polarizations in an orthogonal basis. The scattering matrix is the key point for all the concepts relating radar polarimetry that will be defined next in this section, which is organized as follows. First, a description of wave polarization parameters and the scattering matrix representation will be given. Next, the different polarization scattering matrices used to describe the polarization characteristics of targets will be defined. Finally, a brief description of target decomposition techniques will be presented.

\subsubsection{Plane wave polarization}

A generic spherical coordinate system widely used in remote sensing is first established in order to define the polarization ellipse. This is depicted in Figure 3.9, where the coordiantes $(\hat{k}, \hat{v}, \hat{h})$ form a right-handed system.

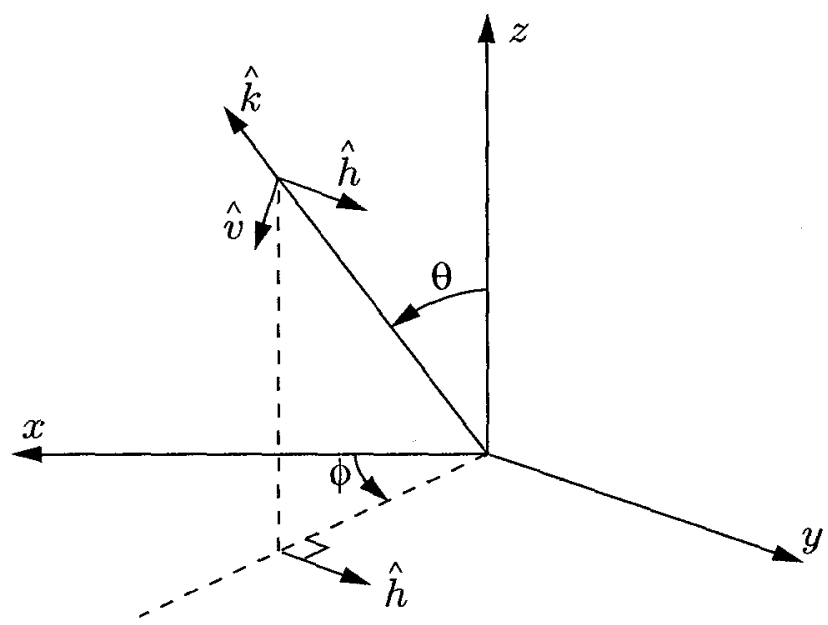

Figure 3.9: Spherical coordinate system for a plane wave

The electric field vector $\vec{E}$ of a plane wave travelling in the direction $\hat{k}$ can be characterized by two orthogonal components, i.e. the horizontal component $E_{h} \cdot \hat{h}$ and the vertical 
component $E_{v} \cdot \hat{v}$. Thus, the electric field as a function of position $\vec{r}$ is expressed as:

$$
\vec{E}(\vec{r})=\left(E_{v} \hat{v}+E_{h} \hat{h}\right) \cdot e^{-j k \hat{k} \cdot \vec{r}}
$$

where $k$ is the wavenumber.

According to Figure 3.9,

$$
\begin{aligned}
& \hat{h}=\frac{\hat{z} \times \hat{k}}{|\hat{z} \times \hat{k}|} \\
& \hat{v}=\hat{h} \times \hat{k}
\end{aligned}
$$

Unitary vectors $\hat{k}, \hat{v}$ and $\hat{h}$ can be defined in terms of spherical angles:

$$
\begin{aligned}
& \hat{k}=\sin \theta \cos \phi \hat{x}+\sin \theta \sin \phi \hat{y}+\cos \theta \hat{z} \\
& \hat{h}=-\sin \phi \hat{x}+\cos \phi \hat{y} \\
& \hat{v}=\cos \theta \cos \phi \hat{x}+\cos \theta \sin \phi \hat{y}-\sin \theta \hat{z} .
\end{aligned}
$$

Considering expression (3.68) and assuming, without loss of generality, that the propagation direction $\hat{k}$ and the position vector $\vec{r}$ are parallel, the vertical and horizontal components of vector $\vec{E}$ can be written as:

$$
\begin{aligned}
& E_{v}(\vec{r})=A_{v} e^{-j k r}=a_{v} e^{j \phi_{v}} e^{-j k r} \\
& E_{h}(\vec{r})=A_{h} e^{-j k r}=a_{h} e^{j \phi_{h}} e^{-j k r},
\end{aligned}
$$

where $A_{v}$ and $A_{h}$ are the amplitudes of $E_{v}(\vec{r})$ and $E_{h}(\vec{r})$, respectively, which can be expressed in terms of modulus $\left(a_{v}\right.$ and $\left.a_{h}\right)$ and phase $\left(\phi_{v}\right.$ and $\left.\phi_{h}\right)$. Now, the instantaneous value of the field is calculated as:

$$
\begin{aligned}
& E_{v}(\vec{r}, t)=\Re\left(E_{v}(\vec{r}) e^{j \omega t}\right)=a_{v} \cos \left(\omega t-k r+\phi_{v}\right) \\
& E_{h}(\vec{r}, t)=\Re\left(E_{h}(\vec{r}) e^{j \omega t}\right)=a_{h} \cos \left(\omega t-k r+\phi_{h}\right) .
\end{aligned}
$$

If these expressions are plotted as a function of time on the $v-h$ plane, an ellipse is described. Thus, the concept of polarization refers to the locus described by the tip of the electric field vector projected onto a plane orthogonal to the direction of the wave propagation, that is, the $v-h$ plane. In general, this locus is an ellipse which is defined by the orientation angle, $\Psi$, and the ellipticity angle, $\chi$. Figure 3.10 shows a representation of the polarization ellipse. Since there are two possible senses of rotation of the electric field vector, the IEEE Antenna Standard defines that a wave has a right-handed polarization if the sense of rotation is clockwise when viewed from the rear of the wave in the direction of propagation $\hat{k}$. This criterion is illustrated in Figure 3.10 where a right-handed wave is plotted. In this case the wave is travelling into the page, and perpendicular to it, and the observation point, which is looking into the same direction $\hat{k}$, is located at the rear of the wave. Assuming the same 


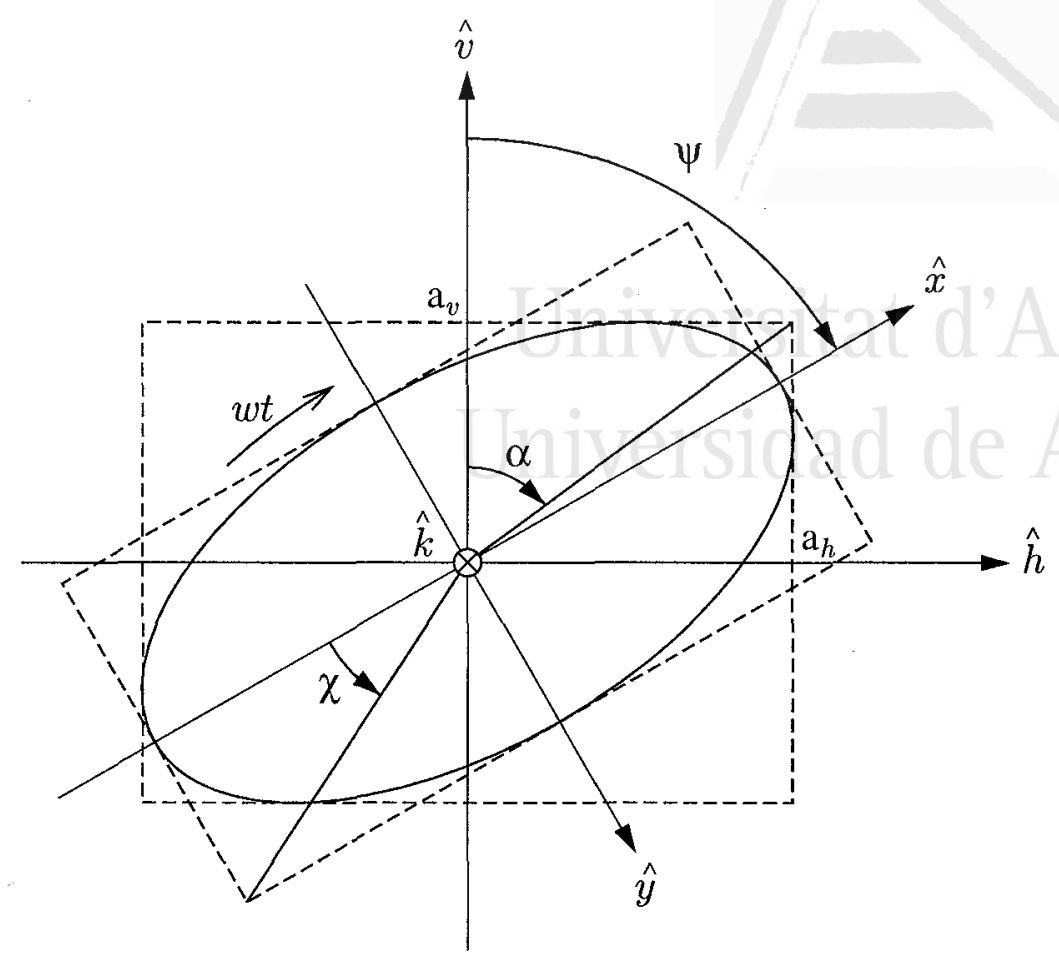

Figure 3.10: The polarization ellipse in the $v-h$ plane

criterion, the polarization is left-handed if the rotation is counterclockwise, when observed from the rear [UE9O].

Therefore, the polarization state of the wave can be described by only three parameters, i.e. $a_{v}, a_{h}$ and $\Delta \phi=\phi_{h}-\phi_{v}$, which are related to the ellipticity and orientation angles as:

$$
\begin{aligned}
& \tan 2 \Psi=\tan \left(2 \frac{a_{h}}{a_{v}}\right) \cos \Delta \phi \\
& \sin 2 \chi=\sin \left(2 \frac{a_{h}}{a_{v}}\right) \sin \Delta \phi
\end{aligned}
$$

According to the previous expressions a wave has linear polarization if $\chi=0$. In this case, $\Psi=0$ corresponds to vertical polarization and $\Psi=\pi / 2$ to horizontal polarization. On the other hand, $\chi=\pi / 4$ corresponds to the left-handed circular polarization and $\chi=-\pi / 4$ to the right-handed circular polarization.

\subsubsection{Change of polarization basis}

Up to this point, the polarization state has been defined in terms of the $\mathrm{h}-\mathrm{v}$ linear orthogonal polarization basis. One reason to represent the polarimetric information in this way is the simplicity of the required hardware to obtain these polarizations. Nevertheless, in some 
applications, such as the maximization of the returned power by choosing an arbitrary polarization, it may be more convenient to use another orthogonal elliptic basis $(\hat{x}, \hat{y})$. This task is accomplished by means of a $2 \times 2$ complex unitary transformation matrix $\mathcal{U}$ :

$$
\vec{E}_{x y}=\mathcal{U} \vec{E}_{h v}
$$

The transformation matrix $\mathcal{U}$ can be expressed in terms of the changes in the ellipticity and orientation angles of the polarization ellipse as:

$$
\mathcal{U}(\Psi, \chi)=\left[\begin{array}{cc}
e^{j \nu} & 0 \\
0 & e^{-j \nu}
\end{array}\right] \cdot\left[\begin{array}{cc}
\cos \chi & -j \sin \chi \\
-j \sin \chi & \cos \chi
\end{array}\right] \cdot\left[\begin{array}{cc}
\cos \Psi & \sin \Psi \\
-\sin \Psi & \cos \Psi
\end{array}\right]
$$

where $\nu$ is the phase reference of the new polarization state. In radar polarimetry this phase reference is taken as zero since it is not characteristic of the wave polarization. Therefore:

$$
\mathcal{U}(\Psi, \chi)=\left[\begin{array}{cc}
\cos \chi & -j \sin \chi \\
-j \sin \chi & \cos \chi
\end{array}\right] \cdot\left[\begin{array}{cc}
\cos \Psi & \sin \Psi \\
-\sin \Psi & \cos \Psi
\end{array}\right]
$$

Note that this matrix must be unitary, i.e. $\mathcal{U}^{-1}=\mathcal{U}^{* T}$, in order to maintain invariant all the wave polarimetric properties, that is to say, the total power remains invariant as well as the determinant of the matrix, and the scattering matrix in the new basis is also symmetric.

\subsubsection{Partially polarized waves}

The polarization of plane waves can be alternatively represented by the Stokes Vector $\vec{g}$. This is particularly useful in practical situations where the polarization state can change in a random fashion due to the non-deterministic behaviour of the electric field as a function of time. The more common situation is when the polarization state changes randomly but around a certain average polarization state. In this case, the wave is said to be partially polarized. If the wave polarization state is anyone at a given instant with the same propability, then the wave is said to be unpolarized.

The complex field descriptor is not an appropriate descriptor since it could induce incorrect results when the averaging process is applied on the polarimetric data, since multiple cancellations among phasors may appear. Instead, a power descriptor is used where the absolute phases are removed and only amplitude values are considered. The Stokes Vector has been widely used in optics and radar, and is expressed as:

$$
\vec{g}=\left[\begin{array}{c}
I \\
Q \\
U \\
V
\end{array}\right]=\left[\begin{array}{c}
\left|E_{v}\right|^{2}+\left|E_{h}\right|^{2} \\
\left|E_{v}\right|^{2}-\left|E_{h}\right|^{2} \\
2 \Re\left(E_{v} E_{h}^{*}\right) \\
-2 \Im\left(E_{v} E_{h}^{*}\right)
\end{array}\right]=I\left[\begin{array}{c}
1 \\
\cos 2 \psi \cos 2 \chi \\
\sin 2 \psi \cos 2 \chi \\
\sin 2 \chi
\end{array}\right]
$$

where the asterisk denotes the complex conjugate operation. 
The four components of the Stokes vector satisfy the following relationship:

$$
I^{2}=Q^{2}+U^{2}+V^{2}
$$

The parameter $I$ is proportional to the total power of the wave, whereas $Q$ is the difference of the intensities in both polarizations. On the other hand, $U$ and $V$ contain phase information.

For unpolarized waves, both components of the electromagnetic field $E_{v}$ and $E_{h}$ are uncorrelated. According to this, the averaged Stokes vector has only one nonzero element, $I$, whereas $Q=U=V=0$. On the other hand, for a partially polarized wave, which can be considered as the sum of a completely polarized wave and an unpolarized wave, it is accomplished that

$$
I^{2} \geq Q^{2}+U^{2}+V^{2}
$$

In that case, it is defined the degree of polarization as the power density of the polarized part of the wave divided by the total power density:

$$
m=\frac{\sqrt{Q^{2}+U^{2}+V^{2}}}{I} .
$$

Note that an incoherent averaging process (in time or space) must be performed on the Stokes vector components in order to correctly represent partially polarized waves, so it can be better expressed as:

$$
\vec{g}=\left[\begin{array}{c}
\left\langle\left|E_{v}\right|^{2}\right\rangle+\left\langle\left|E_{h}\right|^{2}\right\rangle \\
\left\langle\left|E_{v}\right|^{2}\right\rangle-\left\langle\left|E_{h}\right|^{2}\right\rangle \\
\left\langle 2 \Re\left(E_{v} E_{h}^{*}\right)\right\rangle \\
\left\langle-2 \Im\left(E_{v} E_{h}^{*}\right)\right\rangle
\end{array}\right]
$$

\subsubsection{The scattering matrix}

Throughout the previous lines the characterization of the wave polarization has been performed by means of the polarization ellipse and the Stokes vector. When an electromagnetic wave impinges on a scatterer, currents are induced in the scatterer and, as a result, it acts as a source of electromagnetic radiation. Hence, in order to characterize the polarimetric response of a single target, it is necessary to relate the incident field on the target to the scattered field by the same element. This information is arranged in a matrix form, called scattering matrix.

The relation between the indicent electric field $\vec{E}^{i}$ and the scattered electric field $\vec{E}^{s}$ is given by [KenS2]

$$
\vec{E}^{s}=\frac{e^{-j k r}}{r} \mathbf{S} \vec{E}^{i}
$$

where $\mathbf{S}$ is the scattering matrix which describes the scattering behavior of a single target for a given frequency and direction. According to a given coordinate system, which is the 


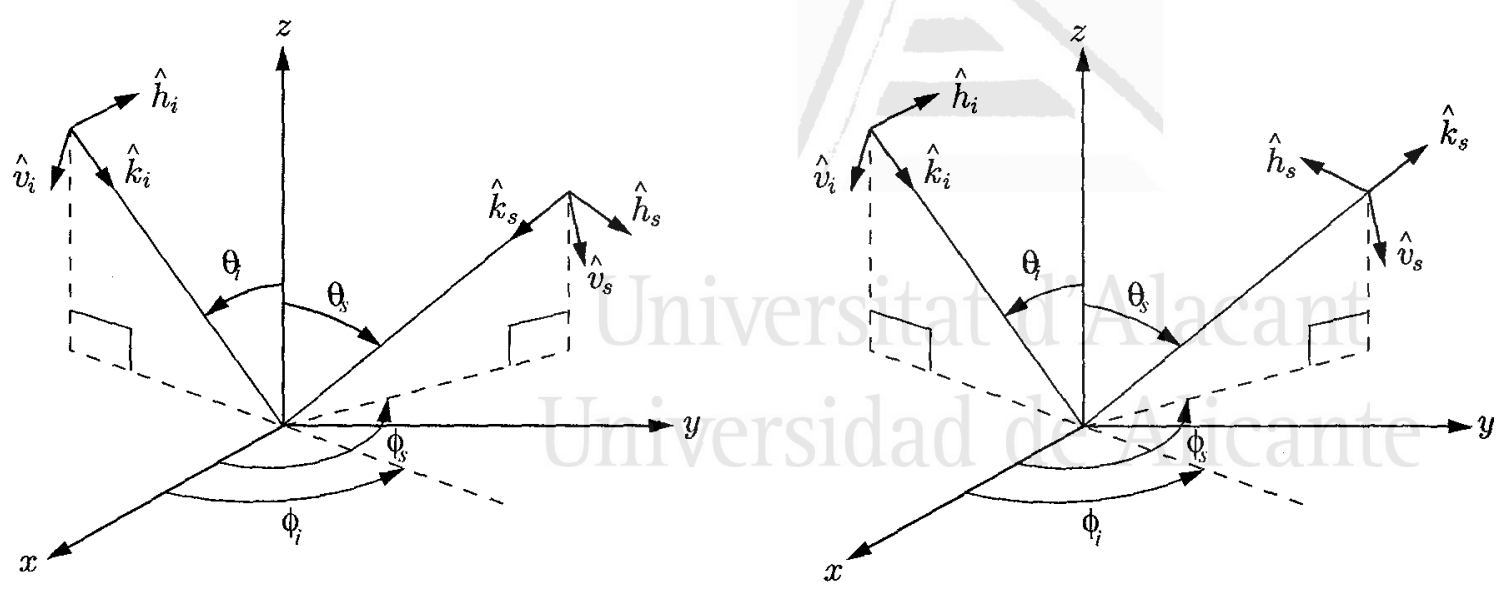

Figure 3.11: BSA (left) and FSA (right) conventions

same for both transmit and receive antennas, and using an orthogonal linear basis $(\hat{h}, \hat{v})$, equation (3.88) is expressed as:

$$
\left[\begin{array}{l}
E_{v}^{s} \\
E_{h}^{s}
\end{array}\right]=\frac{e^{-j k r}}{r}\left[\begin{array}{ll}
S_{v v} & S_{v h} \\
S_{h v} & S_{h h}
\end{array}\right]\left[\begin{array}{l}
E_{v}^{i} \\
E_{h}^{i}
\end{array}\right]
$$

The $r^{-1}$ coefficient represents the spherical nature of the wave and quantifies the attenuation in the propagation path. On the other hand, the exponential term accounts for the delay of the wave.

\subsubsection{Coordinate system conventions}

Every element of the scattering matrix is a complex ratio that relates the scattered electric field in the far-range region in an observation direction $\hat{k}_{s}$ and in a particular polarization, to the incident electric field in the direction $\hat{k}_{i}$ with a particular polarization. Therefore, the incidence and scattering directions must be previously defined. In radar measurements, there exists two general cases depending on the location of the transmit and receive antennas. A monostatic radar transmits and receives echoes with the two antennas located at the same position. In fact, the same antenna can be used to transmit and receive the signal. On the other hand, a bistatic radar makes use of antennas positioned at different locations.

Independently from the monostatic or bistatic case, there exist two conventions about the coordinate system to be used, which are known as Backward Scattering Alignment (BSA) and Forward Scattering Alignment (FSA). Figure 3.11 depicts both coordinates systems.

The BSA convention defines the unit vector $(\hat{k}, \hat{v}, \hat{h})$ with respect to the antenna polarization, and hence, it is also known as antenna coordinates. This is the preferred convention in backscattering problems. The FSA convention is a wave-based coordinate system since it 
defines the unit vectors with respect to the direction of propagation. This convention is the best suited for the treatment of bistatic measurements and in the formulation of multiple scattering scenarios.

The incident electric fields for both conventions are identical, whereas scattered fields are related by expression (3.90):

$$
\vec{E}_{F S A}^{s}=\left[\begin{array}{cc}
1 & 0 \\
0 & -1
\end{array}\right] \vec{E}_{B S A}^{s}
$$

which gives the following relationship for the scattering matrices:

$$
\mathbf{S}_{F S A}=\left[\begin{array}{cc}
1 & 0 \\
0 & -1
\end{array}\right] \mathbf{S}_{B S A}
$$

In the backscattering case, the property of reciprocity for electromagnetic fields leads to the following equality in the BSA convention:

$$
S_{h v}=S_{v h}
$$

However, the same property in the FSA convention for backscattering problems gives

$$
S_{h v}=-S_{v h}
$$

The BSA coordinate system will be used for the analysis of all backscattering problems treated throughout this thesis.

\subsubsection{Vectorization of the scattering matrix}

It is very usual to represent the polarimetric information of a target or scatterer in a vectorized form, which is called the target vector. For a scattering matrix in the $h-v$ basis (hereafter named linear or lexicographic basis) this is expressed as:

$$
\vec{k}_{L}=\left[\begin{array}{c}
S_{v v} \\
S_{v h} \\
S_{h v} \\
S_{h h}
\end{array}\right]
$$

which has the advantage that its entries are directly related to the radar system measurables.

If a basis transformation of the scattering matrix is applied, the target vector will change accordingly. A very useful target vector representation is the one given by the Pauli basis, which is defined as:

$$
\vec{k}_{P}=\frac{1}{\sqrt{2}}\left[\begin{array}{c}
S_{v v}+S_{h h} \\
S_{v v}-S_{h h} \\
S_{v h}+S_{h v} \\
j\left(S_{v h}-S_{h v}\right)
\end{array}\right] .
$$


The Pauli basis is used in most cases in this thesis since its components represent deterministic scattering mechanisms that appear in radar measurements, i.e. they have a clear physical meaning. Moreover, the mechanisms are orthogonal, which allows their separation even when second order scattering statistics are computed. The first component in expression (3.95) represents an odd-bounce scattering mechanism, the second one is an evenbounce contribution, the third mechanism is a tilted $45^{\circ}$ even-bounce mechanism, and the fourth one is interpreted as a transformation of all polarizations states into their orthogonal states.

In the case of backscattering measurements and a reciprocal target, the scattering matrix, and hence, the target vector can be represented by only three elements:

$$
\vec{k}_{L}=\left[\begin{array}{c}
S_{v v} \\
\sqrt{2} S_{v h} \\
S_{h h}
\end{array}\right] \quad \vec{k}_{P}=\frac{1}{\sqrt{2}}\left[\begin{array}{c}
S_{v v}+S_{h h} \\
S_{v v}-S_{h h} \\
2 S_{v h}
\end{array}\right] .
$$

Note that factors $\sqrt{2}$ and $\frac{1}{\sqrt{2}}$ are included in order to maintain the total power of the target vector identical to that of the scattering matrix.

\subsubsection{The polarimetric covariance and coherency matrices}

The scattering matrix defines the polarimetric response of a point scatterer, which is supposed to be time and/or space invariant. In that case, the polarimetric properties of the scattered wave remain unchanged. This situation is modified completely in real scenes which can be modelled as a collection of point scatterers randomly located. The radar system measures the coherent superposition of the returns from the scatterers inside a resolution cell. The stored reflectivity will be different from one cell to another since the arrangement and number of single scatterers are also different among the cells. In this case the scattered waves become partially polarized and, consequently, the information provided by the scattering matrix is no longer useful since its entries must be also considered as random processes. This leads necessarily to a statistical analysis of the polarimetric SAR data.

The four entries of the scattering matrix can be modelled with a zero-mean, complex, Gaussian pdf, according to the Central Limit Theorem [Pap84]. This implies that the scattering matrix can not provide target information any more since $E\left\{\vec{k}_{L, P}\right\}=0$. As a consequence, higher order statistics of the scattering matrix channels will be used.

This statistical analysis is commonly carried out by means of the polarimetric covariance and coherency matrices. These polarimetric matrix descriptors are defined as the outer product of the target vector and its conjugate transpose. If the target vector is defined by using the lexicographic basis it yields the covariance matrix, which provides the Hermitian products between the elements of the scattering matrix. On the other hand, the use of the target vector obtained from the Pauli basis provides the coherency matrix. Again, the advantage of this 
matrix descriptor is the direct relationship between its elements and elementary physical scattering mechanisms. Thus, these matrices are:

$$
\begin{aligned}
& \mathbf{T}=\left\langle\vec{k}_{P} \cdot \vec{k}_{P}^{* T}\right\rangle=\mathbf{T}^{* T} \\
& \mathbf{C}=\left\langle\vec{k}_{L} \cdot \vec{k}_{L}^{* T}\right\rangle=\mathbf{C}^{* T}
\end{aligned}
$$

Both matrices are Hermitian positive semidefinite and share the same positive eigenvalues. In addition, they are related through the following unitary transformation:

$$
\mathbf{C}=\mathbf{A}^{* T} \mathbf{T A}
$$

wherein

$$
\mathbf{A}=\frac{1}{\sqrt{2}}\left[\begin{array}{cccc}
1 & 0 & 0 & 1 \\
1 & 0 & 0 & -1 \\
0 & 1 & 1 & 0 \\
0 & j & -j & 0
\end{array}\right]
$$

In the case of backscattering measurements for a reciprocal distributed target in the BSA convention, which is the most common in radar polarimetry, coherency and covariance matrices exhibit the following forms:

$$
\begin{gathered}
\mathbf{T}=\frac{1}{2}\left[\begin{array}{ccc}
\left\langle\left|S_{v v}+S_{h h}\right|^{2}\right\rangle & \left\langle\left(S_{v v}+S_{h h}\right)\left(S_{v v}-S_{h h}\right)^{*}\right\rangle & \left\langle 2\left(S_{v v}+S_{h h}\right) S_{v h}^{*}\right\rangle \\
\left\langle\left(S_{v v}-S_{h h}\right)\left(S_{v v}+S_{h h}\right)^{*}\right\rangle & \left\langle\left|S_{v v}-S_{h h}\right|^{2}\right\rangle & \left\langle 2\left(S_{v v}-S_{h h}\right) S_{v h}^{*}\right\rangle \\
\left\langle 2 S_{v h}\left(S_{v v}+S_{h h}\right)^{*}\right\rangle & \left\langle 2 S_{v h}\left(S_{v v}-S_{h h}\right)^{*}\right\rangle & \left\langle 4\left|S_{v h}\right|^{2}\right\rangle
\end{array}\right] \\
\mathbf{C}=\left[\begin{array}{ccc}
\left\langle\left|S_{v v}\right|^{2}\right\rangle & \left\langle\sqrt{2} S_{v v} S_{v h}^{*}\right\rangle & \left\langle S_{v v} S_{h h}^{*}\right\rangle \\
\left\langle\sqrt{2} S_{v h} S_{v v}^{*}\right\rangle & \left\langle 2\left|S_{v h}\right|^{2}\right\rangle & \left\langle\sqrt{2} S_{v h} S_{h h}^{*}\right\rangle \\
\left\langle S_{h h} S_{v v}^{*}\right\rangle & \left\langle\sqrt{2} S_{h h} S_{v h}^{*}\right\rangle & \left\langle\left|S_{h h}\right|^{2}\right\rangle
\end{array}\right]
\end{gathered}
$$

It must be pointed out the differences between these second order statistics and the scattering matrices. The covariance and coherency matrices not only carry the information of the channels but also the correlation properties among them.

Note also that the covariance and the coherency matrices represent the same information but it is arranged in a different way.

\subsubsection{Mueller and Kennaugh matrices}

The Mueller matrix is a $4 \times 4$ real matrix that relates the Stokes vectors of the incident and scattered waves, i.e.:

$$
\vec{g}^{s}=\frac{1}{r^{2}} \mathbf{M} \vec{g}^{i}
$$

50 
For a general case, the Mueller matrix can be written as [CP96]:

$$
\mathbf{M}=\left[\begin{array}{cccc}
A_{0}+B_{0} & C+N & H+L & F+I \\
C-N & A+B & E+J & G+K \\
H-L & E-J & A-B & D+M \\
I-F & K-G & M-D & A_{0}-B_{0}
\end{array}\right]
$$

If the backscattering case with reciprocity and the BSA convention is considered, the Mueller matrix becomes

$$
\mathbf{M}_{B S A}=\left[\begin{array}{cccc}
A_{0}+B_{0} & C & H & F \\
C & A_{0}+B & E & G \\
H & E & A_{0}-B & D \\
-F & -G & -D & A_{0}-B_{0}
\end{array}\right]
$$

It is very common in radar polarimetry to design an optimal reception system. To achieve this, the antenna must be matched to the incoming scattered wave. This matching optimization is accomplished by conjugating the received scattered field. Consequently, when the BSA convention is used, the new propagation vector for the scattered wave becomes $\hat{k}_{s}^{\prime}=-\hat{k}_{s}$. This leads to a change of sign of the ellipticity angle $\chi$ and, as a result, to a change of sign of the last element of the Stokes vector for the received field. This is accounted for with the inversion of the sign of the last row of the Mueller matrix. This matrix is now called the Kennaugh matrix [Ken52, Gui94].

It must be pointed out that both the Mueller and Kennaugh matrices are also known as power reflection matrices, and that these matrices jointly with the coherency and covariance matrices are incoherently averaged.

Once at this point, the scatterer descriptors have been formulated. The central element for the treatment of polarimetric information is the scattering matrix, but the necessity of having second order statistics in order to describe the correlation effects among scatterers has been also introduced. Figure 3.12 illustrates the relationships among scattering descriptors.

It must be noted that transitions from the power reflection matrices to the scattering matrix are not always possible. This is a consequence of the non-deterministic nature of the polarized waves, i.e., in real situations electromagnetic waves are partially polarized, which is in contrast with the scattering matrix definition where pure polarization waves are assumed. Therefore the second order descriptors are a result of an averaging process, and hence, this makes that the unique correspondence between the scattering matrix and the Mueller, the coherency or the covariance matrix is not always feasible. Indeed, a set of constraints on the elements of the coherency matrix can be derived in order to verify that the rank of this matrix must be equal to one, which is the condition that must be observed (see [CP96]). In that case, the equivalence between any incoherently averaged matrix and the scattering matrix would be kept. 
Chapter 3. Theory of Polarimetric SAR Interferometry

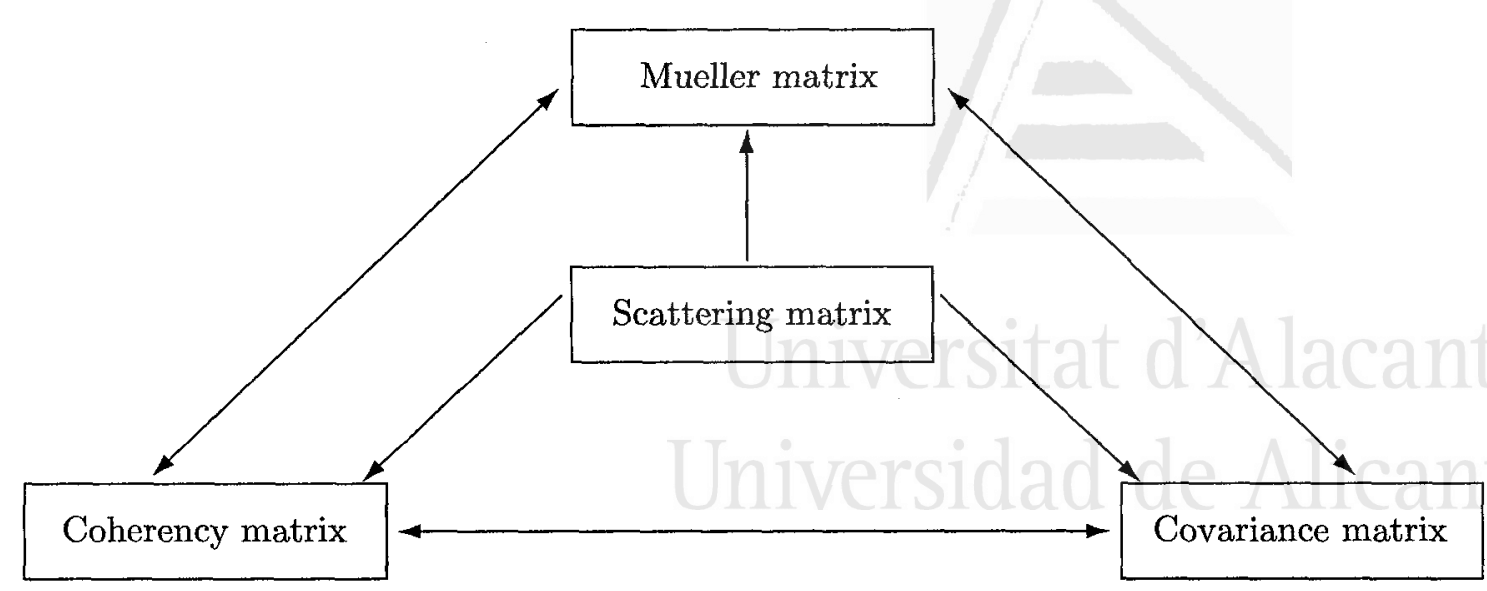

Figure 3.12: Relationships among scattering descriptors. Transition from power descriptors to the scattering matrix is only possible if the rank of the coherency matrix is equal to one

\subsubsection{Target decomposition theory: eigenvector decomposition}

Target decomposition (TD) techniques deal with the extraction of physical information of the target by means of the analysis of the scattering descriptor matrices. The main goal of TD theorems is to decompose the averaged descriptor into a set of matrices representing different physical scattering mechanisms. All the different approaches to perform this decomposition are briefly summarized in Chapter 1, and some conclusions can be extracted about their applicability. On the one hand, coherent decompositions of the scattering matrix are appropriate if only one or two dominant scattering mechanisms are expected, which is not the case for most of natural targets. In addition, coherent averaging is affected by speckle noise. On the other hand, the Huynen-type decompositions are based on the separation between a single scattering mechanism and a noise contribution, which is not the general case for the analysis of many natural targets. Within this group of techniques, A. Freeman [DD98] introduced a three component model based on surface scattering, double-bounce scattering and volume (random) scattering, which has shown to be useful for classification purposes in mature forests. Finally, target decomposition techniques based on the eigenvalue-eigenvector diagonalization of the coherency matrix have been extensively applied in remote sensing due to the advantages that they present: 1) the eigenvalue problem is basis invariant, i.e., the same result is obtained for any basis employed in the polarization definition, and 2) three statistically independent scattering mechanisms are obtained. Furthermore, from the interpretation of the eigenvalues, another set of parameters with physical meaning have been introduced: entropy, alpha angle and anisotropy. They have shown to provide useful information for a wide variety of natural and man-made targets.

Next section is aimed to present the eigenvalue-based TD approach, since this decomposition technique has been used in this thesis for the analysis and interpretation of polarimetric data, which supports some of the conclusions presented in this work. 


\subsubsection{Eigenvector decomposition of the coherency matrix}

The eigenvector-based decomposition of the averaged coherency matrix states that it can be written as a sum of orthogonal matrices made up from the eigenvectors and weighted by the corresponding eigenvalues. This three-component decomposition obeys to the following relationship:

$$
\langle\mathrm{T}\rangle=\left\langle\vec{k}_{P} \cdot \vec{k}_{P}^{* T}\right\rangle \text {. }
$$

where

$$
\Sigma=\left[\begin{array}{ccc}
\lambda_{1} & 0 & 0 \\
0 & \lambda_{2} & 0 \\
0 & 0 & \lambda_{3}
\end{array}\right]
$$

is a $3 \times 3$ diagonal matrix with nonnegative real elements, $\lambda_{1} \geqslant \lambda_{2} \geqslant \lambda_{3} \geqslant 0$, which are the eigenvalues of the coherency matrix; and

$$
\mathbf{U}_{3}=\left[\begin{array}{lll}
\vec{e}_{1} & \vec{e}_{2} & \vec{e}_{3}
\end{array}\right]=\left[\begin{array}{ccc}
\cos \alpha_{1} & \cos \alpha_{2} & \cos \alpha_{3} \\
\sin \alpha_{1} \cos \beta_{1} e^{j \delta_{1}} & \sin \alpha_{2} \cos \beta_{2} e^{j \delta_{2}} & \sin \alpha_{3} \cos \beta_{3} e^{j \delta_{3}} \\
\sin \alpha_{1} \sin \beta_{1} e^{j \gamma_{1}} & \sin \alpha_{2} \sin \beta_{2} e^{j \gamma_{2}} & \sin \alpha_{3} \sin \beta_{3} e^{j \gamma_{3}}
\end{array}\right]
$$

is a $3 \times 3$ matrix whose columns are the eigenvectors of the coherency matrix: $\vec{e}_{1}, \overrightarrow{e_{2}}$ and $\overrightarrow{e_{3}}$.

Hence, the coherency matrix can be expressed as:

$$
\mathbf{T}=\lambda_{1}\left(\vec{e}_{1} \vec{e}_{1}^{* T}\right)+\lambda_{2}\left(\vec{e}_{2} \vec{e}_{2}^{* T}\right)+\lambda_{3}\left(\vec{e}_{3} \vec{e}_{3}^{* T}\right)
$$

Each $3 \times 3$ matrix in equation (3.109) represents a coherency matrix of an elementary scattering mechanism, whose importance or weight in the overall response of the resolution cell is determined by its associated eigenvalue [CPO7].

Note that since this approach corresponds to an eigenvector decomposition, it can be stated that it is basis invariant, so the same result will be obtained despite of the basis employed to define the wave polarization. In addition, the three scattering mechanisms are statistically independent.

The parameterization of eigenvectors in (3.108) by means of angles $\alpha, \beta, \delta$ and $\gamma$ leads to the extraction of physical information about the scattering mechanisms. In principle, $\delta$ and $\gamma$ have not a straightforward interpretation, but $\alpha$ and $\beta$ provide a physical meaning regarding the type of scattering mechanism and the orientation of the scatterer, respectively. For example, the $\alpha=0$ case indicates scattering by a sphere or a flat surface normal to the incident wave. At the other extreme, $\alpha=90^{\circ}$, corresponds to a dihedral-type (or helix) scattering. Another important case is $\alpha=45^{\circ}$ which corresponds to a dipole-type scattering because the scattered wave becomes linearly polarized.

Despite the definition of three scattering mechanisms within a resolution cell, the random structure of natural targets suggests a probabilistic interpretation of the scattering process. Thus, the target is modelled as a three symbol Bernoulli process which means that the three 
scattering mechanisms can occur with probabilities $p_{1}, p_{2}$ and $p_{3}$. These probabilities can be computed as:

$$
p_{i}=\frac{\lambda_{i}}{\sum_{i=1}^{3} \lambda_{i}}
$$

with

$$
\sum_{i=1}^{3} p_{i}=1
$$

From probabilities $p_{i}$ a scalar quantity can be defined that provides a measure of the randomness of the resolution cell in terms of electromagnetic behavior. This concept is known as target entropy and was first introduced in [Clo86, CP95]. It is expressed as:

$$
H=-\sum_{i=1}^{3} p_{i} \log _{3} p_{i}
$$

If a nondepolarizing target is present then $H=0$, and the coherency matrix has only one nonzero eigenvalue. On the other hand, if $H=1$ the target depolarizes all the incident waves and polarimetric information would become completely useless.

From the probabilistic point of view, a mean scattering mechanism can be extracted. This is expressed by a mean parameterized eigenvector in the following way:

$$
\overline{\vec{e}}=\left[\begin{array}{c}
\cos \bar{\alpha} \\
\sin \bar{\alpha} \cos \bar{\beta} e^{j \bar{\delta}} \\
\sin \bar{\alpha} \sin \bar{\beta} e^{j \bar{\gamma}}
\end{array}\right],
$$

where

$$
\begin{aligned}
& \bar{\alpha}=p_{1} \alpha_{1}+p_{2} \alpha_{2}+p_{3} \alpha_{3} \\
& \bar{\beta}=p_{1} \beta_{1}+p_{2} \beta_{2}+p_{3} \beta_{3} \\
& \bar{\delta}=p_{1} \delta_{1}+p_{2} \delta_{2}+p_{3} \delta_{3} \\
& \bar{\gamma}=p_{1} \gamma_{1}+p_{2} \gamma_{2}+p_{3} \gamma_{3}
\end{aligned}
$$

Besides, another parameter known as anisotropy is defined [Por98] as a measure of the relative difference between the second and third eigenvalues of the target decomposition:

$$
A=\frac{\lambda_{2}-\lambda_{3}}{\lambda_{2}+\lambda_{3}}
$$

Low anisotropies indicate that the probability of the third scattering mechanism is similar to that of the second mechanism, whereas a high anisotropy value represents targets with only two dominant scattering mechanisms. 


\subsection{Theory of Polarimetric SAR Interferometry}

As outlined in Chapter 1, the combination of polarimetry and interferometry provides a significant improvement in the characterization of land covers. On the one hand, polarimetry allows the determination of the scattering properties of the scene. On the other hand, interferometry is sensitive to the vertical structure of a distributed target. Therefore, polarimetric SAR interferometry appears as a useful technique in order to separate different scattering centers in a vertical distribution. The formulation regarding the interferometric phase and the interferometric coherence, explained in Section 3.2, is generalized by incorporating the polarimetric information. Consequently, it will be possible to generate interferograms, as well as their corresponding coherence maps, for different polarization channels. This technique, known as PolInSAR, enables an improvement in the development of biophysical parameters retrieval algorithms.

In this section the general vector interferometry formulation will be provided as a starting point for algorithms including polarimetric and interferometric information, which will be used in this thesis. Afterwards, a procedure that maximizes the interferometric coherence by means of the selection of an appropriate linear combination of polarization channels [CP98] will be outlined. This approach has become a work of reference on PolInSAR-based retrieval algorithms and its relevance relies on the ability to generate coherence maps with the highest values of coherence which, consequently, yield the best quality interferograms.

\subsubsection{Vector Interferometry}

The extension of the interferometric phase and coherence to the vector case makes use of the target vectors defined in Section 3.3.2.2. Those target vectors contain the complete polarimetric information associated with each resolution cell of the SAR images. For convenience, the vectorization based on the Pauli spin matrices will be used, although the corresponding formulation can be derived on the basis of the $\vec{k}_{L}$ vectors (see Section 3.3.2.2).

Considering the backscattering case from a reciprocal medium, the target vector presents the following form:

$$
\vec{k}=\frac{1}{\sqrt{2}}\left[\begin{array}{c}
S_{v v}+S_{h h} \\
S_{v v}-S_{h h} \\
2 S_{v h}
\end{array}\right]
$$

which corresponds to $\vec{k}_{P}$ in $(3.95)$.

The polarimetric information of the pair of SAR images will be contained in two different scattering vectors, $\vec{k}_{1}$ and $\vec{k}_{2}$, for image 1 and image 2 , respectively. Using the outer products formed by combinations of both scattering vectors, it is also possible to define the following 
$3 \times 3$ matrices:

$$
\begin{aligned}
& \left\langle\mathbf{T}_{11}\right\rangle=\left\langle\vec{k}_{1} \vec{k}_{1}^{* T}\right\rangle \\
& \left\langle\mathbf{T}_{22}\right\rangle=\left\langle\vec{k}_{2} \vec{k}_{2}^{* T}\right\rangle \\
& \left\langle\mathbf{\Omega}_{12}\right\rangle=\left\langle\vec{k}_{1} \vec{k}_{2}^{* T}\right\rangle
\end{aligned}
$$

where $\left\langle T_{11}\right\rangle$ and $\left\langle T_{22}\right\rangle$ correspond to the averaged coherency matrices containing the polarimetric response for each individual image, and $\left\langle\Omega_{12}\right\rangle$ is a $3 \times 3$ complex matrix that contains the relationship between both SAR images, incorporating the polarimetric as well as the interferometric information. For the sake of simplicity in the formulation, the expectation value symbols $\langle\cdot\rangle$ will be omitted in the following lines.

In order to generate an interferogram, which is the complex cross correlation of two scalar complex numbers, the polarimetric information contained in $\vec{k}_{1}$ and $\vec{k}_{2}$ is properly manipulated. Two normalized complex vectors $\vec{w}_{1}$ and $\vec{w}_{2}$ are introduced. Then, the projection of the target vectors $\vec{k}_{1}$ and $\vec{k}_{2}$ onto the vectors $\vec{w}_{1}$ and $\vec{w}_{2}$ is calculated resulting in the scalar values $\mu_{1}$ and $\mu_{2}$ defined as, respectively,

$$
\begin{aligned}
& \mu_{1}=\vec{w}_{1}^{* T} \vec{k}_{1} \\
& \mu_{2}=\vec{w}_{2}^{* T} \vec{k}_{2}
\end{aligned}
$$

As observed, $\mu_{1}$ and $\mu_{2}$ are linear combinations of the elements of the vectors $\vec{k}_{1}$ and $\vec{k}_{2}$. The coefficients of these linear combinations are the elements of the vectors $\vec{w}_{1}$ and $\vec{w}_{2}$. Then, a new expression for the interferometric observable is obtained as:

$$
\mu_{1} \mu_{2}^{*}=\left(\vec{w}_{1}^{* T} \vec{k}_{1}\right)\left(\vec{w}_{2}^{* T} \vec{k}_{2}\right)^{*}=\vec{w}_{1}^{* T} \Omega_{12} \vec{w}_{2}
$$

from which the interferometric phase is:

$$
\phi=\arg \left(\mu_{1} \mu_{2}^{*}\right)=\arg \left(\vec{w}_{1}^{* T} \Omega_{12} \vec{w}_{2}\right)
$$

In addition, the interferometric coherence can be generalized to the vector case, yielding:

$$
|\gamma|=\frac{\left|\left\langle\mu_{1} \mu_{2}^{*}\right\rangle\right|}{\sqrt{\left\langle\mu_{1} \mu_{1}^{*}\right\rangle\left\langle\mu_{2} \mu_{2}^{*}\right\rangle}}=\frac{\left|\left\langle\vec{w}_{1}^{* T} \Omega_{12} \vec{w}_{2}\right\rangle\right|}{\sqrt{\left\langle\vec{w}_{1}^{* T} \mathbf{T}_{11} \vec{w}_{1}\right\rangle\left\langle\vec{w}_{2}^{* T} \mathbf{T}_{22} \vec{w}_{2}\right\rangle}}
$$

Note that the use of vectors $\vec{w}_{1}$ and $\vec{w}_{2}$ can be interpreted as the selection of arbitrary scattering mechanisms in both scenes.

\subsubsection{Coherence Optimization}

The optimization of the interferometric coherence by using all the polarimetric information was formulated in [CPOB] and consists in combining the scattering mechanisms in both SAR 
images so that the coherence associated with each pixel becomes maximum. It can be accomplished by properly selecting $\vec{w}_{1}$ and $\vec{w}_{2}$.

This optimization problem has been solved in [CP98] by maximizing the complex Lagrangian $L^{*}$ defined as:

$$
L^{*}=\vec{w}_{1}^{* T} \Omega_{12} \vec{w}_{2}+\lambda_{1}\left(\vec{w}_{1}^{* T} \mathbf{T}_{11} \vec{w}_{1}-C_{1}\right)+\lambda_{2}\left(\vec{w}_{2}^{* T} \mathbf{T}_{\mathbf{2} 2} \vec{w}_{2}-C_{2}\right),
$$

where $\lambda_{1}$ and $\lambda_{2}$ are Lagrange multipliers introduced for maximizing the numerator of $(3.127)$ while keeping the denominator constant, and $C_{1}$ and $C_{2}$ are constants.

Since the first derivatives must equal zero, then:

$$
\begin{aligned}
& \frac{\partial L^{*}}{\partial \vec{w}_{1}^{* T}}=\Omega_{12} \vec{w}_{2}+\lambda_{1} \mathbf{T}_{11} \vec{w}_{1}=0 \\
& \frac{\partial L^{*}}{\partial \vec{w}_{2}^{* T}}=\Omega_{12}^{* T} \vec{w}_{1}+\lambda_{2}^{*} \mathbf{T}_{22} \vec{w}_{2}=0
\end{aligned}
$$

Therefore, we arrive at the following pair of $3 \times 3$ complex eigenvalue problems:

$$
\begin{aligned}
& \mathbf{T}_{\mathbf{1 1}}{ }^{-1} \boldsymbol{\Omega}_{\mathbf{1 2}} \mathbf{T}_{\mathbf{2 2}}{ }^{-1} \boldsymbol{\Omega}_{\mathbf{1 2}}{ }^{* T} \vec{w}_{1}=\nu \vec{w}_{1} \\
& \mathbf{T}_{\mathbf{2 2}}{ }^{-1} \boldsymbol{\Omega}_{\mathbf{1 2}}{ }^{* T} \mathbf{T}_{\mathbf{1 1}}{ }^{-1} \boldsymbol{\Omega}_{12} \vec{w}_{2}=\nu \vec{w}_{2}
\end{aligned}
$$

where $\nu=\lambda_{1} \lambda_{2}^{*}$.

Applying the eigenanalysis in (3.131) provides three real and non-negative eigenvalues, i.e. $\nu_{1} \geqslant \nu_{2} \geqslant \nu_{3} \geqslant 0$. Each eigenvalue is related to a pair of eigenvectors $\left(\vec{w}_{1_{j}}\right.$ and $\vec{w}_{2_{j}}$, with $j=1,2,3$ ), one for each image. The maximum coherence is given by the square root of the maximum eigenvalue:

$$
\gamma_{o p t}=\sqrt{\nu_{1}}
$$

while its corresponding eigenvectors are denoted as the optimum ones: $\vec{w}_{1_{\text {opt }}}$ and $\vec{w}_{2_{\text {opt }}}$.

Hence, the interferogram with the highest possible coherence is found as a projection of the target vectors $\vec{k}_{1}$ and $\vec{k}_{2}$ onto $\vec{w}_{1_{o p t}}$ and $\vec{w}_{2_{o p t}}$, yielding two optimized scalar complex values $\mu_{1_{\text {opt }}}$ and $\mu_{2_{\text {opt }}}$. The resulting interferometric phase becomes:

$$
\phi=\arg \left(\mu_{1_{\text {opt }}} \mu_{2_{\text {opt }}}^{*}\right)=\arg \left(\vec{w}_{1_{\text {opt }}}^{* T} \vec{k}_{1} \vec{k}_{2}^{* T} \vec{w}_{2_{\text {opt }}}\right)=\arg \left(\vec{w}_{1_{\text {opt }}}^{* T} \Omega_{12} \vec{w}_{2_{\text {opt }}}\right)
$$

Note that since vectors $\vec{w}_{1}$ and $\vec{w}_{2}$ are complex, they may introduce a phase shift in the interferogram. Therefore, an additional condition must be satisfied so that the interferometric phase information appear only in the scattering vectors $\vec{k}_{1}$ and $\vec{k}_{2}$ :

$$
\arg \left(\vec{w}_{1_{\text {opt }}}^{* T} \vec{w}_{2_{\text {opt }}}\right)=0
$$

Additionally, if there exist orthogonality among the three pairs of eigenvectors, there appears a statistical independence between the scattering mechanisms they represent and, hence, it 
is possible to generate three different interferograms, each one related to a scattering mechanism independent from the others:

$$
\mu_{1_{j}} \mu_{2_{j}}^{*}=\left(\vec{w}_{1_{j}}^{* T} \vec{k}_{1}\right)\left(\vec{w}_{2_{j}}^{* T} \vec{k}_{2}\right)^{*}=\vec{w}_{1_{j}}^{* T} \Omega_{12} \vec{w}_{2_{j}}
$$

The relative phase differences among these three interferograms can be calculated and, as a result, the topographic difference among the effective phase centers of the corresponding scattering mechanisms is retrieved. The phase difference between two mechanisms $i$ and $j$ is given by:

$$
\Delta \phi_{i j}=\arg \left(\mu_{1_{i}} \mu_{2_{i}}^{*}\right)-\arg \left(\mu_{1_{j}} \mu_{2_{j}}^{*}\right)
$$

The general optimization approach explained before leads to a coherence maximization purely based on a mathemathical point of view, which considers that the retrieved polarization states may be different for both images. However, this fact could difficult the interpretation of the results, since it is assumed that the target can be described with two different polarization states, which should not be the real case.

For a monostatic case and when no temporal decorrelation affects the data acquisition, the optimized polarization states will be identical if the baseline is small. In fact, it is possible to constrain the coherence optimization in order to retrieve the same polarization state for both images [GD04]. Basically, this approach consists of rewriting the coupled matrix equations in (3.130) by using $\vec{w}_{1}=\vec{w}_{2}=\vec{w}$ and $\lambda_{1} \approx \lambda_{2}=\lambda$. This yields

$$
\begin{aligned}
\Omega_{12} \vec{w} & =-\lambda \mathbf{T}_{\mathbf{1 1}} \vec{w} \\
\boldsymbol{\Omega}_{\mathbf{1 2}}{ }^{* T} \vec{w} & =-\lambda \mathbf{T}_{\mathbf{2 2}} \vec{w} .
\end{aligned}
$$

Now, the addition of these equations leads to a single matrix equation

$$
\left[\mathbf{T}_{11}+\mathbf{T}_{\mathbf{2 2}}\right]^{-1}\left[\Omega_{12}+\Omega_{12}^{* T}\right] \vec{w}=-\lambda \vec{w}
$$

In this case, each eigenvalue $\lambda$ is associated with an eigenvector $\vec{w}$, i.e. polarization state, used for both acquisitions.

It is shown [GD04] that the constrained case (see also [CK05] for an alternative procedure that yields the same result) can improve the performance of the unconstrained case in terms of accuracy of the separation of the scattering mechanisms, i.e. it reduces the retrieved height distributions. The effect of the number of looks was also considered and it was demonstrated that the constrained optimization produces accurate results using around 10 looks, whereas the unconstrained optimization requires more than 30 looks to yield similar results with the same experimental data set. 


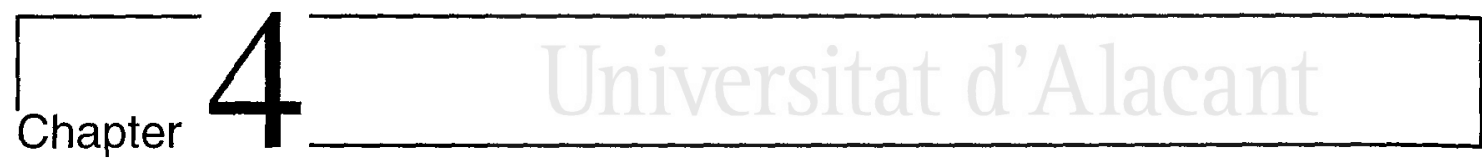

\section{Direct Electromagnetic Models of Agricultural Crops}

\subsection{Introduction}

As described in Chapter 2, two kinds of strategies of modelling can be applied to face the computation of backscattering from natural covers by using coherent scattering models. On the one hand, there exists a group of techniques known as full-wave scattering models, which entail a precise characterization of the scene. Basically, this approach identifies each element of the scene (i.e. trunks, leaves, branches, ground, etc.) with different canonical geometrical forms, whose electromagnetic responses are known (i.e. cylinders, ellipsoids, ellipses, disks, etc.) in order to calculate in an accurate way the backscatter response and its variations.

Similarly to the full-wave scattering models, a second group of approaches makes use of the phase information from scattering interactions. However, in this case, the relationships among the radar observables (interferometric coherence, backscattering coefficient and polarization dependence) and biophysical parameters (such as vegetation height, ground topography, etc.) are obtained through a statistical modelling of the total backscattering response of the medium. As a result, these models can describe the physical structure of the scene by means of a more reduced set of parameters compared to the full-wave models. Here, polarimetric SAR interferometry makes use of these relationships to provide inversion algorithms that can produce precise estimates for the physical parameters, with the additional advantage of a very simple interpretation model. Taking into account the simplicity of this model, two different approaches can be applied according to the morphology of the vegetation: a random volume over ground (RVoG) and an oriented volume over ground (OVoG). The mathematical formulation for the random volume, the random volume over ground and the oriented volume models was introduced in [TMMY96, TC99, TSO0]. Nevertheless, the influence of the ground contribution on the oriented volume case was not explicitly studied in those references (see also [CPBOO]). 
Next sections are devoted to provide the mathematical background for the coherent electromagnetic modelling. Firstly, in Section 4.2, an example of a full-wave scattering model for a specific kind of crop is presented. Further, in Section 4.3, the RVoG and OVoG models are described in detail, since these are widely used and discussed throughout this thesis. It must be stressed that the effect of the ground surface on the polarimetric cross-correlation products when the vegetation volume is oriented has not been explicitly addressed before. Here, a formal expression accounting for this effect is also provided.

Note that in the formulation presented in this chapter the scattering matrix and its elements are denoted by $\mathbf{F}$ and $f$, respectively, in order to maintain the same notation as in the papers by Treuhaft et al. [TMMv96, TC99, TS00].

\subsection{Full-wave scattering model}

In this section, a simplified first order coherent scattering model is presented in order to provide an example of full-wave scattering model. It can be applied to rice crops, although can be easily extended to other agricultural plants by changing the characteristic physical parameters.

The model considers the rice as an arrangement of plants clusters over the soil flooded with water, which is modeled as a perfectly conducting plate. Plants are modeled considering the contribution of two independent layers of dielectric cylinders with different length values. The first one corresponds to the stems without branches, that originate at ground level and grow up with certain elevation angle around the vertical. This layer, in interaction with the ground, constitutes the more important contribution to the total microwave scattering of a real rice plant. The second layer corresponds to the upper part and it is generated by adding short dielectric cylinders to the upper end of first layer of cylinders. More details about the geometry and architecture of the simulated plants can be found in Chapter 5 .

The scattering model takes into account the coherent sum of several basic contributions to the total scattering field [TCK $92, \mathrm{YKJ}+92, \mathrm{LS} 95$ ]. In this work, we assume a first order scattering solution, i.e. the stem-ground interaction dominates the electromagnetic response of the model, considering multiple interaction between cylinders negligible in this approach. For a complete information about multiple scattering see [OSSO2] and [CSOO]. Fig. 4.1 shows all the contributions included in this interaction [LSEGBEF99, LS95].

In order to calculate the total scattering in the far field region, it is necessary to previously obtain the scattering by a single cylinder-ground set. The dielectric cylinder response is computed by assuming that the length of the cylinder is much larger than the wavelength and the dielectric constant has a significant imaginary part. Hence, the scattered fields of a finitelength cylinder are approximated by those of an infinite cylinder [LS95]. The addition of all four contributions represented in Fig. 4.1 is obtained by considering the ground as an infinite dielectric half-space. Once a cylinder-ground set is characterized, the scattering matrix of a 


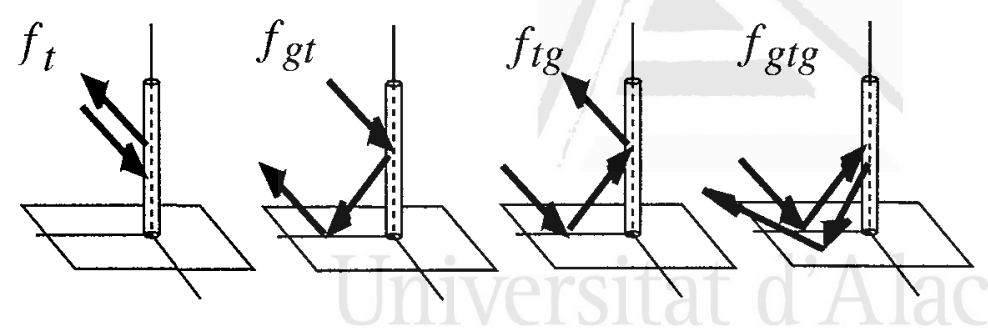

Figure 4.1: Contributions considered in the full-wave scattering model.

single stem is expressed as:

$$
\left[\begin{array}{ll}
f_{v v}^{n} & f_{v h}^{n} \\
f_{h v}^{n} & f_{h h}^{n}
\end{array}\right]
$$

so it is possible to write the total scattered field from the rice plants as:

$$
\left[\begin{array}{c}
E_{v}^{s} \\
E_{h}^{s}
\end{array}\right]=\left[\begin{array}{ll}
\hat{v}_{s} & \hat{h}_{s}
\end{array}\right]\left(\sum_{n=1}^{N}\left[\begin{array}{ll}
f_{v v}^{n} & f_{v h}^{n} \\
f_{h v}^{n} & f_{h h}^{n}
\end{array}\right] e^{j k_{0}\left(\hat{k}_{i}-\hat{k}_{s}\right) \overrightarrow{r_{n}}}\right) \cdot\left[\begin{array}{c}
E_{v}^{i} \\
E_{h}^{i}
\end{array}\right] e^{j k_{0} \hat{k}_{s} \vec{r}}
$$

where $N$ is the number of stems, $k_{0}$ is the free space wavenumber, $\hat{k}_{i}$ and $\hat{k}_{s}$ are the directions of propagation of the incident and scattered waves, respectively, $\vec{r}_{n}$ is the position of $n$-th stem and $\vec{r}$ is the observation point at far range.

Equation (4.2) defines mathematically the simplest approximation to model the electromagnetic response of the rice crop. An additional effect that also may be taken into account is the scattering introduced by the soil flooded with water. For simplicity, assuming a square resolution cell, this contribution is modeled as a perfectly conducting square plate with dimensions $a$ and $b$, and it has been computed by means of the Physical Optics approximation [UE90]. For the backscattering case it can be written as

$$
f_{\text {water }}=-\frac{i a b}{\lambda_{0}}\left(\hat{n}_{g} \cdot \hat{k}_{i}\right) \frac{\sin \left(k_{0} a \hat{k}_{i} \cdot \hat{x}\right)}{k_{0} a \hat{k}_{i} \cdot \hat{x}} \frac{\sin \left(k_{0} b \hat{k}_{i} \cdot \hat{y}\right)}{k_{0} b \hat{k}_{i} \cdot \hat{y}}
$$

where $\hat{n}_{g}$ is the normal unit vector to the surface, and $\hat{x}$ and $\hat{y}$ are the $X$ and $Y$ axis unit vectors. This effect only modifies the copolar contributions, since the cross-polar term becomes zero for the backscattering direction.

It must be pointed out that the contribution of the surface below the rice plants becomes important only within a certain interval of incidence angle around the vertical direction (see Fig. 4.2), and it depends on the plate area and on the frequency of the signal. This effect 
is incorporated into the model by applying superposition. As a result, the simulated global scattering yields

$$
\left[\begin{array}{c}
E_{v}^{s} \\
E_{h}^{s}
\end{array}\right]=\left[\begin{array}{ll}
\hat{v}_{s} & \hat{h}_{s}
\end{array}\right]\left(\sum_{n=1}^{N}\left[\begin{array}{ll}
f_{v v}^{n} & f_{v h}^{n} \\
f_{h v}^{n} & f_{h h}^{n}
\end{array}\right] e^{j k_{0}\left(\hat{k}_{i}-\hat{k}_{s}\right) \vec{r}_{n}}+\left[\begin{array}{cc}
f_{\text {water }} & 0 \\
0 & f_{\text {water }}
\end{array}\right]\right) \cdot\left[\begin{array}{c}
E_{v}^{i} \\
E_{h}^{i}
\end{array}\right] e^{j k_{0} \hat{k}_{s} \vec{r}}
$$
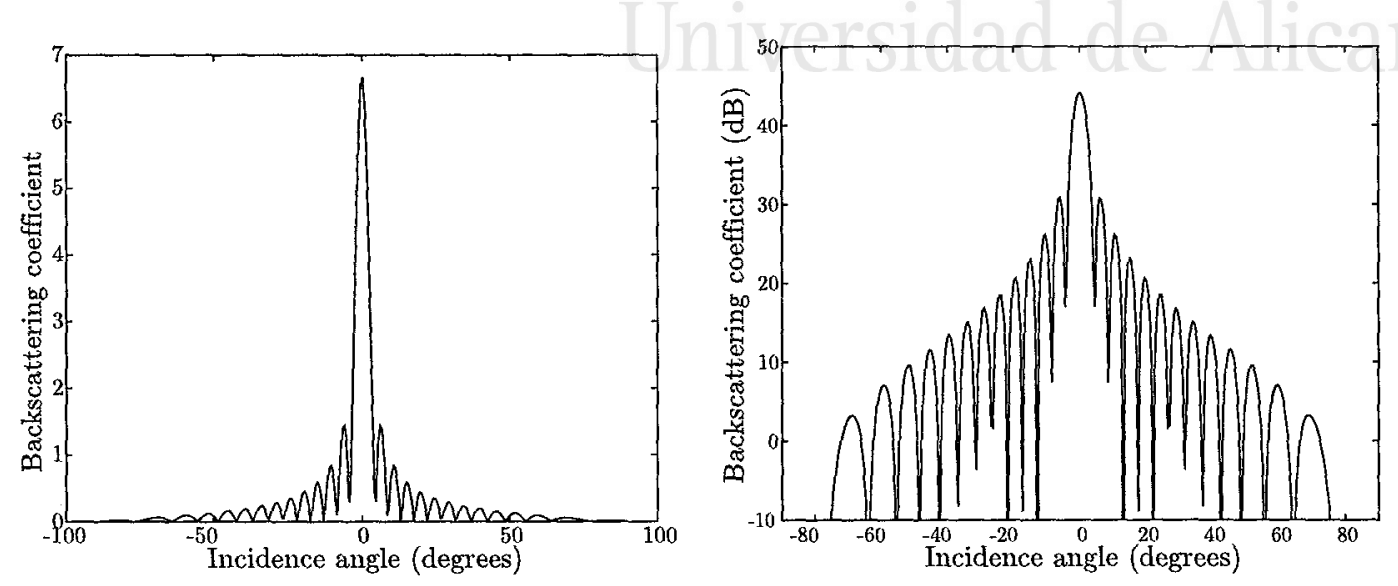

Figure 4.2: Backscattering coefficient from a perfectly conducting square plate as a function of incidence angle: a) Linear scale ; b) dB scale

Depending on the characteristics of each scene, it could be necessary to include the attenuation effect (by absortion and scattering in other directions) caused by the medium [TK\$85, YKJ+92] on the wave when it travels through the vegetation cover. It can be calculated by means of the Forward Scattering Theorem [TKS85, TKD00], which states that for a statistically uniform medium, the horizontal and vertical components, $E_{h}$ and $E_{v}$, of the propagated wave. They are governed by the following expression:

$$
\left[\begin{array}{c}
\frac{\partial E_{h}}{\partial s} \\
\frac{\partial E_{v}}{\partial s}
\end{array}\right]=\left[\begin{array}{cc}
j k_{0}+M_{h h} & M_{h v} \\
M_{v h} & j k_{0}+M_{v v}
\end{array}\right] \cdot\left[\begin{array}{c}
E_{h} \\
E_{v}
\end{array}\right]
$$

where $s$ is the slant-range dimension, and

$$
M_{q p}=\frac{j 2 \pi n_{0}}{k_{0}}\left\langle f_{q p}(\theta, \phi ; \theta, \phi)\right\rangle, \quad q, p=v, h
$$

In expression (4.6) the ensemble average, $\langle\cdot\rangle$, is performed over all the scattering elements in the same direction indicated by the incident field, $(\theta, \phi)$. The number of scatterers per volume unit, $n_{0}$, can also be expressed as the total number of plants per area unit, $n_{s}$, divided by the crop height, $h$. 


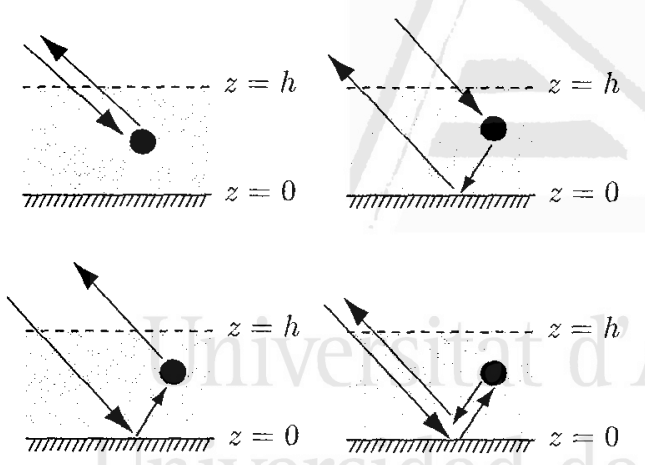

Figure 4.3: Propagation paths for each scattering mechanism.

Therefore, expression (4.6) can be rewritten as:

$$
M_{q p}=\frac{j 2 \pi}{k_{0}} \frac{n_{s}}{h}\left\langle f_{q p}(\theta, \phi ; \theta, \phi)\right\rangle, \quad q, p=v, h
$$

Note that the scene presents statistic azimuthal symmetry, and hence, ideally the cross-polar components become zero:

$$
M_{h v}=M_{v h}=0
$$

Then, effective propagation constants for linear polarizations become:

$$
\begin{aligned}
& k_{h}=k_{0}-j M_{h h} \\
& k_{v}=k_{0}-j M_{v v}
\end{aligned}
$$

Finally, by adding the attenuation effect in expression (4.4), scattering coefficients are expressed as:

$$
f_{q p}^{\prime n}=f_{q p}^{n} e^{-M_{q q} d_{m e c h}^{s}} e^{-M_{p p} d_{m e c h}^{i}}
$$

where $d_{m e c h}^{s}$ is the path covered by the wave after being scattered off by an element inside the medium, and $d_{m e c h}^{i}$ is the distance through the medium before impinging on the same scatterer. It is clear that these paths depend on the scattering mechanism considered for each particle, as it is shown in Fig. 4.3.

This full-wave scattering model was implemented during the development of this thesis and applied in [FGMVR 103 ] and [FOMVLSBBO3] in order to simulate the backscattering coefficient of a rice sample. The corresponding results showed an overestimation in the copolar channels and an underestimation in the crosspolar channel, since the multiple scattering was 
neglected [YKS ${ }^{+92]}$. The inclusion of an upper layer with horizontal structures, such as bent stems, and the effect of the wave attenuation would provide a more accurate estimation of the backscattering coefficient.

Note also that this type of coherent modelling relies on the consideration of a big amount of parameters (i.e. positions, shapes, sizes, different dielectric constants, ...), which make the parameter inversion a very difficult task. Some works have addressed this problem by obtaining polynomials of some parameters and by applying numerical techniques for the inversion [L.S99a, Ls99b].

\subsection{Simple models: RVoG and OVoG}

As mentioned before, the simplicity of the RVoG and the OVoG models can be exploited jointly with the capability of PolInSAR systems to separate the different scattering mechanisms within a layered structure. However, that simplicity arises after the construction of a general coherent scattering model that needs of a considerable mathematical background. The formulation describing these models was originally introduced in [TMMv96, TC99, TS00], and it will be explained in the following lines.

The idea behind this type of models is to derive an analytical relationship between the physical structure of the vegetated scene and the cross correlation between received signals at both ends of the baseline.

The geometry of the problem is depicted in Fig. 4.4. Here $\vec{R}_{e 1}$ and $\vec{R}_{e 2}$ are the ends of the baseline.

The received signal at ends 1 and 2 are $\vec{E}_{\hat{t}_{1}}$ and $\vec{E}_{\hat{t}_{2}}$, respectively, where subscripts $\hat{t}_{1}$ and $\hat{t}_{2}$ indicate the transmitted polarizations. Note that with this notation we will refer hereafter to the received echoes at ends $\vec{R}_{e 1}$ and $\vec{R}_{e 2}$, respectively (i.e. $\vec{E}_{\hat{t}_{1}}\left(\vec{R}_{e 1}\right)$ and $\vec{E}_{\hat{t}_{2}}\left(\vec{R}_{e 2}\right)$ ). Coordinate $x$ represents the ground-range dimension.

The general interferometric cross-product is expressed as:

$$
\left\langle\hat{r}_{1} \cdot \vec{E}_{\hat{t}_{1}} \cdot \hat{r}_{2}^{*} \cdot \vec{E}_{\hat{t}_{2}}^{*}\right\rangle=\left\langle\sum_{j=1}^{M} \hat{r}_{1} \cdot \vec{E}_{\hat{t}_{1}}\left(\vec{R}_{j}\right) \sum_{k=1}^{M} \hat{r}_{2}^{*} \cdot \vec{E}_{\hat{t}_{2}}^{*}\left(\vec{R}_{k}\right)\right\rangle
$$

where the angle brackets perform an ensemble average over the scattering characteristics and spatial locations of scatterers. Subscripts $\hat{r}_{1}$ and $\hat{r}_{2}$ represent the respective unitary vectors for the received polarization at each end of the interferometer, and $M$ is the total number of contributing signals backscattered from elements located at $\vec{R}_{j}$. If statistical independence 


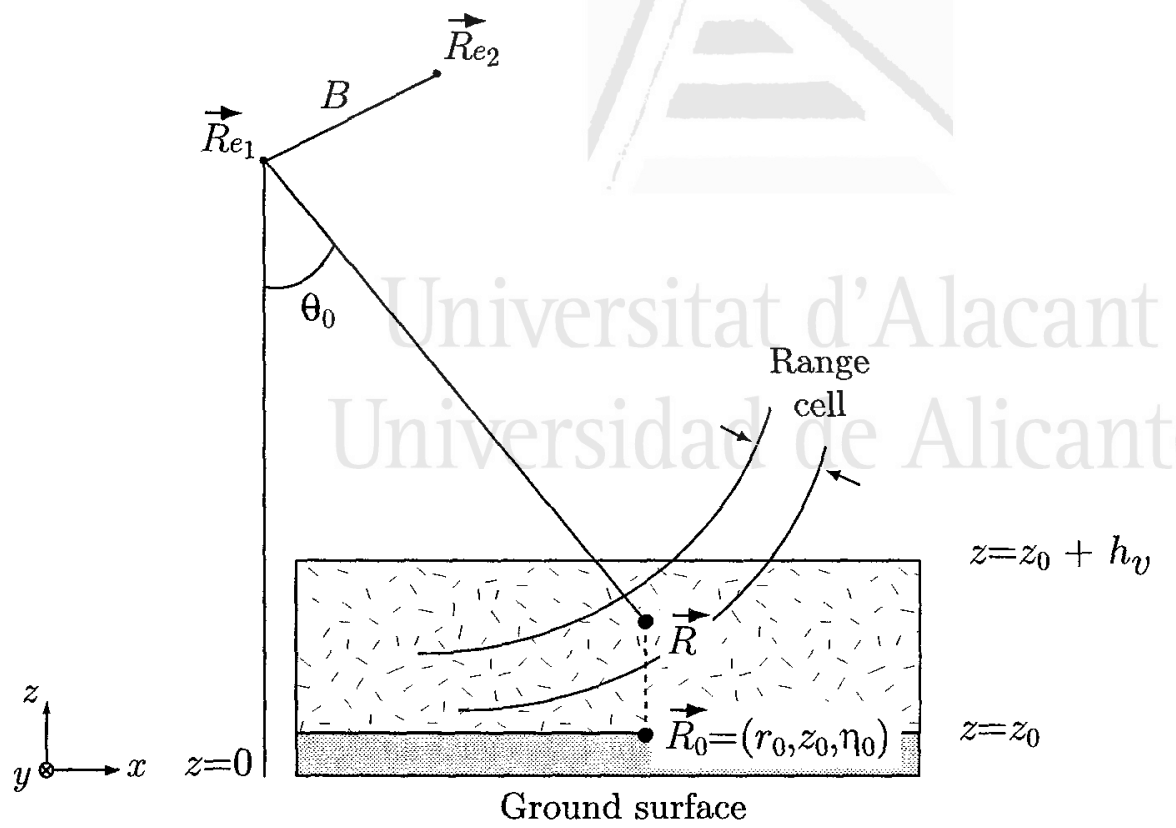

Figure 4.4: Interferometric scattering geometry for the RVoG and the OVoG models.

is assumed among different scattering elements, any of these particles correlates only with itself. Therefore, expression (4.12) can be transformed into (4.13)

$$
\begin{aligned}
\left\langle\hat{r}_{1} \cdot \vec{E}_{\hat{t}_{1}} \cdot \hat{r}_{2}^{*} \cdot \vec{E}_{\hat{t}_{2}}^{*}\right\rangle & =\sum_{j_{v}=1}^{M_{v}}\left\langle\hat{r}_{1} \cdot \vec{E}_{\hat{t}_{1}}\left(\vec{R}_{j_{v}}\right) \cdot \hat{r}_{2}^{*} \cdot \vec{E}_{\hat{t}_{2}}^{*}\left(\vec{R}_{j_{v}}\right)\right\rangle+ \\
& +\sum_{j_{g}=1}^{M_{g}}\left\langle\hat{r}_{1} \cdot \vec{E}_{\hat{t}_{1}}\left(\vec{R}_{j_{g}}\right) \cdot \hat{r}_{2}^{*} \cdot \vec{E}_{\hat{t}_{2}}^{*}\left(\vec{R}_{j_{g}}\right)\right\rangle
\end{aligned}
$$

where $M_{v}$ is the number of signals from the volume and $M_{g}$ from the ground. Note that this expression allows a separate analysis of volume scattering and direct ground scattering, which is decomposed into several ground patches with uncorrelated responses. Nevertheless, as we will see later in the text, the volume contribution is coupled with the double-bounce scattering originated by the interaction of the ground and the elements of vegetation.

Cross correlations in (4.13) can be rewritten (see equation (4.14)) using the probability density functions of locating a volume scatterer and a surface scatterer at $\vec{R}_{j_{v}}$ and $\vec{R}_{j_{g}}$, which are $P_{v o l}\left(\vec{R}_{j_{v}}\right)$ and $P_{\text {surf }}\left(\vec{R}_{j_{g}}\right)$, respectively. Besides, assuming identical statistics for all volume and surface scatterers, and expressing the signals in terms of the Fourier component at the 
central frequency $\omega_{0}$, one can obtain [TMMv96]:

$$
\begin{aligned}
& \left\langle\hat{r}_{1} \cdot \vec{E}_{\hat{t}_{1}} \cdot \hat{r}_{2}^{*} \cdot \vec{E}_{\hat{t}_{2}}^{*}\right\rangle=\sum_{j_{v}=1}^{M_{v}} \int_{\text {volume }} P_{v o l}\left(\vec{R}_{j_{v}}\right) \cdot\left\langle\hat{r}_{1} \cdot \vec{E}_{\hat{t}_{1}}\left(\vec{R}_{j_{v}}\right) \cdot \hat{r}_{2}^{*} \cdot \vec{E}_{\hat{t}_{2}}^{*}\left(\vec{R}_{j_{v}}\right)\right\rangle \cdot d^{3} R_{j_{v}}+ \\
& \left.\quad+\sum_{j_{g}=1}^{M_{g}} \int_{\text {surface }} P_{\text {surf }}\left(\vec{R}_{j_{g}}\right) \cdot\left\langle\hat{r}_{1} \cdot \vec{E}_{\hat{t}_{1}}\left(\vec{R}_{j_{g}}\right) \cdot \hat{r}_{2}^{*} \cdot \vec{E}_{\hat{t}_{2}}^{*}\left(\vec{R}_{j_{g}}\right)\right\rangle \cdot d^{2} R_{j_{g}}=-A\right] \\
& \quad=\int_{\text {volume }} \rho_{0} \cdot W_{r}^{2}\left(\frac{\phi_{1}\left(\vec{R}_{e 1}, \vec{R}\right)}{j k_{0}}-2\left|\vec{R}_{e 1}-\vec{R}_{0}\right|\right) \cdot W_{\eta}^{2}\left(\eta-\eta_{0}\right) \cdot \\
& \quad \cdot\left\langle\hat{r}_{1} \cdot \vec{E}_{\hat{t}_{1}}\left(\vec{R}_{e 1}, \omega_{0} ; \vec{R}\right) \cdot \hat{r}_{2}^{*} \cdot \vec{E}_{\hat{t}_{2}}^{*}\left(\vec{R}_{e 2}, \omega_{0} ; \vec{R}\right)\right\rangle \cdot d^{3} R+ \\
& \quad+\int_{\text {surface }} \sigma_{0} \cdot W_{r}^{2}\left(\frac{\phi_{1}\left(\vec{R}_{e 1}, \vec{R}\right)}{j k_{0}}-2\left|\vec{R}_{e 1}-\vec{R}_{0}\right|\right) \cdot W_{\eta}^{2}\left(\eta-\eta_{0}\right) \cdot \\
& \quad \cdot\left\langle\hat{r}_{1} \cdot \vec{E}_{\hat{t}_{1}}\left(\vec{R}_{e 1}, \omega_{0} ; \vec{R}\right) \cdot \hat{r}_{2}^{*} \cdot \vec{E}_{\hat{t}_{2}}^{*}\left(\vec{R}_{e 2}, \omega_{0} ; \vec{R}\right)\right\rangle \cdot d^{2} R
\end{aligned}
$$

where $\rho_{0}$ and $\sigma_{0}$ are the density of volume and surface scatterers, respectively, $\vec{R}$ is a given scatterer location, and $W_{r}$ and $W_{\eta}$ are the range and azimuth resolution functions, which have been included for the sake of completeness, but they do not have influence in the final interferometric cross products. The term $\phi_{1}\left(\vec{R}_{e 1}, \vec{R}\right)=j 2 k_{0}\left|\vec{R}_{e 1}-\vec{R}\right|$ is the propagation phase of the received field at end 1 , with $k_{0}=\frac{2 \pi}{\lambda}$ being the wavenumber for the central frequency; $\vec{R}_{0}$ is a reference point that corresponds to the center of the range resolution cell. See Fig. 4.4 for the details.

Note that the first integral in (4.14) accounts for the volume and the so-called specular (ground-volume and volume-ground) contributions, whereas the second integral introduces the direct response from the ground.

Sections 4.3.1 and 4.3.2 are intended to show the derivation (following the indications in [TSO0]) of the received fields to be inserted into (4.14), in order to obtain the cross correlation expression as a function of the biophysical parameters.

It must be pointed out that the final expression of the interferometric coherence depends on the operation mode of the interferometer, i.e., single-transmit or ping-pong. Firstly, the formulation regarding the single-transmit mode will be given, as it was derived in [TSOO]. Next, the considerations in order to use this formulation with a ping-pong system will be provided. 


\subsubsection{Random volume over ground surface (RVoG)}

The randomly oriented volume over a ground plane, proposed to address the issue of forest height retrieval and biomass estimation, is one of the simplest vegetation model and assumes that the probability of any scatterer inside the volume to be oriented in one direction is equal to the probability of being oriented in any other. Besides, the underlying ground surface effect is considered in order to obtain a more realistic model. In general, this contribution is composed of the direct ground echoes plus the double bounce signal originated by the ground-stem interaction, which is also known as the dihedral contribution. The relative contribution of these two mechanisms, specially in agricultural applications, depends on the frequency, polarization and incidence angle, as well as the kind and stage of development of vegetation [BQM $[\mathrm{O}, \mathrm{PLM03}]$ and, in principle, neither of these two components can be neglected. For example, in the case of corn, and under certain conditions of the system [MBO4], it is necessary to consider the direct ground return, but however it would not be the case for rice, with the same system, since the soil is flooded.

In this work, the direct ground contribution is assumed to be negligible in comparison with the ground-stem response, and hence, the following formulation corresponds to the random volume over the dihedral contribution. In Figure 4.5 the volume and the dihedral scattering mechanisms mentioned before are depicted.

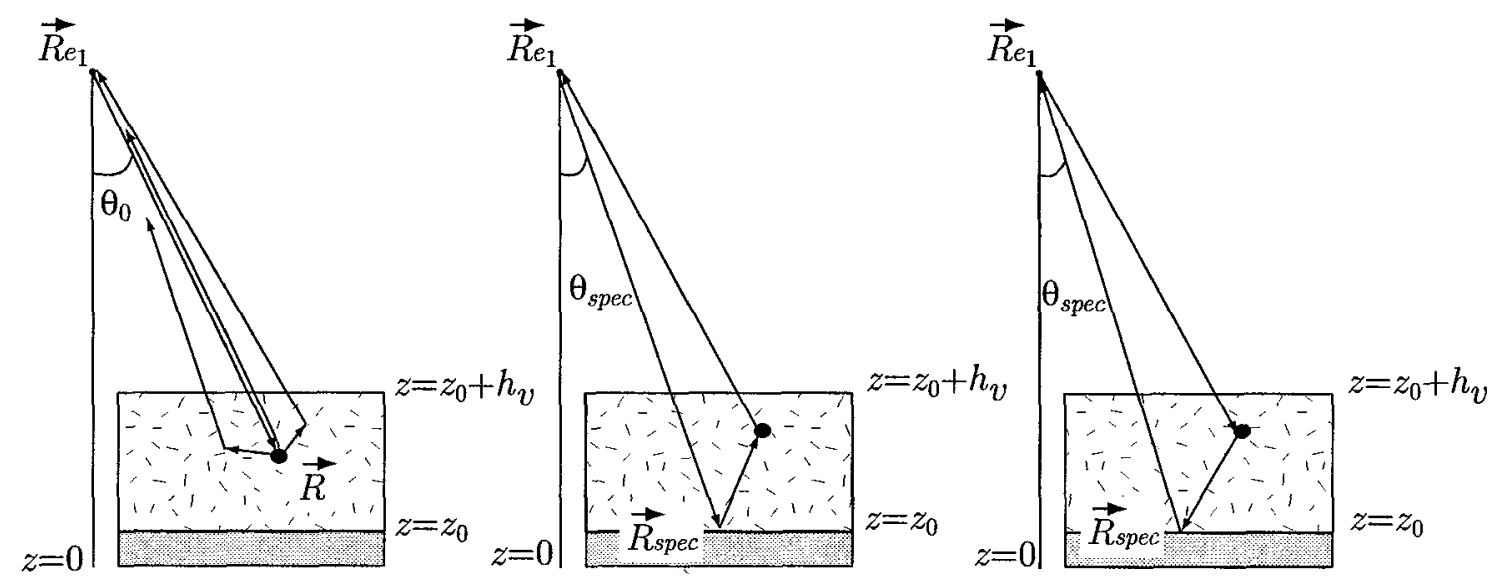

Figure 4.5: Volume and double bounce contributions due to a scatterer at $\vec{R}$.

From the previous discussion, the total backscattered field received at end 1 from a scatterer located at $\vec{R}$ includes the responses of volume and the ground-stem interaction:

$$
\left.\left.\left\langle\vec{E}_{\hat{t}_{1}}\left(\vec{R}_{e 1}, \omega_{0} ; \vec{R}\right)\right\rangle\right\rangle=\left\langle\vec{E}_{\hat{t}_{1}}^{\text {olume }_{1}}\left(\vec{R}_{e 1}\right)\right\rangle+\vec{E}_{\hat{t}_{1}}^{\text {dihedral }_{G V}}\left(\vec{R}_{e 1}\right)\right\rangle+\left\langle\vec{E}_{\hat{t}_{1}}^{\text {dihedral }_{V} G}\left(\vec{R}_{e 1}\right)\right\rangle
$$

where the second term corresponds to the ground-volume signal and the third term to the volume-ground one. 
The derivation of expression for the volume contribution is as follows. First, a free space propagation term is considered and, second, another term accounting for the propagation through the random medium that suffers from attenuation computed by means of the Forward Scattering Theorem [TKS85, TKDO0] (see Section 4.2). Then, the received signal is expressed as:

$$
\left\langle\vec{E}_{\hat{t}_{1}}^{\text {volume }}\left(\vec{R}_{e 1}\right)\right\rangle=\frac{1}{\left|\vec{R}_{e 1}-\vec{R}\right|^{2}} \cdot \mathbf{F}_{b} \cdot \hat{t}_{1} \cdot e^{\left[j 2 k_{0}\left|\vec{R}_{e 1}-\vec{R}_{0}\right|+\frac{j 4 \pi \rho_{0}\left\langle\hat{t} \cdot \mathbf{F}_{f} \cdot t t^{\prime} \cdot\left(h_{v}-z\right)\right.}{k_{0} \cos \theta_{\vec{R}}}\right]}
$$

where $\theta_{\vec{R}}$ is the incidence angle from $\vec{R}_{e 1}$ to $\vec{R}$, that will be assumed as a constant value $\theta_{0}$; $h_{v}$ is the vegetation depth; $z$ is the vertical coordinate; and $\mathbf{F}_{\mathrm{b}}$ is the scattering matrix in the backscattering direction for an element located at $\vec{R}$, which is

$$
\mathbf{F}_{\mathbf{b}}=\left(\begin{array}{ll}
f_{b}^{v v} & f_{b}^{v h} \\
f_{b}^{h v} & f_{b}^{h h}
\end{array}\right)
$$

In (4.16) the term $\left\langle\hat{t} \cdot \mathbf{F}_{\mathbf{f}} \cdot \hat{t}\right\rangle$ is the forward scattering matrix, which in the random volume case is independent on polarization and, as a result, on average the cross-polar coefficients are zero and the copolar contributions are equal. Note that $\hat{t}$ is an arbitrary unitary vector, according to this independence on polarization.

Next, the received signal from the ground-volume interaction, $\vec{E}_{\hat{t}_{1}}^{\text {dihedral }_{G V}}\left(\vec{R}_{e 1}\right)$, will be calculated. Firstly, it is necessary to obtain the incident field on a scattering element at $\vec{R}$, which has two contributions:

$$
\left\langle\vec{E}_{\hat{t}_{1}}\left(\vec{R}, \omega_{0}\right)\right\rangle=\left\langle\vec{E}_{\hat{t}_{1}}\left(\vec{R}, \omega_{0} ; \vec{R}_{e 1}\right)\right\rangle+\left\langle\vec{E}_{\hat{t}_{1}}\left(\vec{R}, \omega_{0} ; \vec{R}_{\text {spec }}\right)\right\rangle
$$

where the first term account for the average direct wave from $\vec{R}_{e 1}$ to $\vec{R}$, and the second one is the ground-reflected signal at point $\vec{R}_{\text {spec }}$, which will be used in this text to indicate the ground-volume or the volume-ground reflection point, since both contributions are assumed to share the same reflection point.

Then, the backscattered field at $\vec{R}_{e 1}$ will be obtained by multiplying the field in (4.18) by the scattering matrix, $\mathbf{F}_{\text {spec } \rightarrow \vec{R}_{e l}}$, that describes the interaction of a wave coming from ground and scattered towards the receiver by the volume scatterer at $\vec{R}$. In addition, terms accounting for the propagation from $\vec{R}$ directly to end 1 must be considered, just as in the same way as indicated in (4.16):

$$
\left\langle\vec{E}_{\hat{t}_{1}}^{\text {dihedral }} \text { GV }\left(\vec{R}_{e 1}\right)\right\rangle=\left\langle\vec{E}_{\hat{t}_{1}}\left(\vec{R}, \omega_{0}\right)\right\rangle \cdot \frac{1}{\left|\vec{R}_{e 1}-\vec{R}\right|} \cdot \mathbf{F}_{s p e c \rightarrow \vec{R}_{e 1}} \cdot e^{j k_{0}\left|\vec{R}_{e 1}-\vec{R}\right|} \cdot e^{\left(\frac{j 2 \pi \rho_{0}\left\langle\hat{t} \cdot \mathbf{F}_{\mathbf{f}} \cdot \hat{t}\right\rangle \cdot\left(h_{v}-z\right)}{k_{0} \cos \theta_{s p e c}}\right)}
$$


As a first step, let us proceed to derive both terms in expression (4.18).

The direct field from transmitter at end 1 impinging on $\vec{R}$ is expressed by a free-space propagation term and an exponential term accounting for the propagation through the volume:

$$
\left\langle\vec{E}_{\hat{t}_{1}}\left(\vec{R}, \omega_{0} ; \vec{R}_{e 1}\right)\right\rangle=\frac{1}{\left|\vec{R}_{e 1}-\vec{R}_{0}\right|} \cdot \hat{t}_{1} \cdot e^{\left[j k_{0}\left|\vec{R}_{e 1}-\vec{R}\right|+\frac{j 2 \pi \rho_{0}\left\langle\hat{f} \cdot \mathbf{F}_{f} \cdot \hat{t}\right) \cdot\left(h_{v}-z\right)}{\hat{k}_{0} \cos \vec{R}}\right]}
$$

Note that in (4.20) it is assumed that $\left|\vec{R}_{e 1}-\vec{R}\right| \approx\left|\vec{R}_{e 1}-\vec{R}_{0}\right|$. The calculation of second term in (4.18) can be made by applying the Kirchhoff approximation [TKS85] for a rough surface with zero average slope. This term is expressed as [TSO0]

$$
\begin{aligned}
& \left\langle\vec{E}_{\hat{t}_{1}}\left(\vec{R}, \omega_{0} ; \vec{R}_{\text {spec }}\right)\right\rangle=\frac{j k_{0} \cdot \hat{t}_{1} \cdot e^{j k_{0} \cdot \mid \vec{R}-\vec{R}_{s p e c}}}{4 \pi\left|\vec{R}-\vec{R}_{s p e c}\right|} \cdot e^{\frac{j 2 \pi \rho_{0}\left(\hat{t} \cdot \mathbf{F}_{f} \cdot \hat{t}\right) \cdot\left(h_{v}+z\right)}{k_{0} \cos \theta_{s p e c}}} \\
& \quad \cdot \int P\left(z^{\prime}, z_{0}\right) d z^{\prime} \int\left[\left\langle R_{\hat{t}_{1}}\left(\theta_{s p e c}\right)\right\rangle\left(\hat{k}_{i n c}-\hat{k}_{r e f}\right) \cdot \hat{n}-\left(\hat{k}_{i n c}+\hat{k}_{r e f}\right) \cdot \hat{n}\right] \\
& \quad \cdot e^{j\left(\hat{k}_{i n c}-\hat{k}_{r e f}\right) \cdot \vec{R}^{\prime}} d x^{\prime} d y^{\prime}
\end{aligned}
$$

where $\left\langle R_{\hat{t}_{1}}\left(\theta_{\text {spec }}\right)\right\rangle$ is the average specular reflection coefficient for polarization $\hat{t}_{1} ; \vec{R}^{\prime}\left(x^{\prime}, y^{\prime}, z^{\prime}\right)$ is the integration variable accounting for the height distribution of the ground; $\vec{k}_{i n c}$ is the incidence wavenumber vector with value $\vec{R}_{s p e c}-\vec{R}_{e 1} ; \vec{k}_{r e f}$ is the reflected wavenumber vector with value $\vec{R}-\vec{R}_{\text {spec }} ; \hat{n}$ is a surface unit normal vector; $P\left(z^{\prime}, z_{0}\right)$ is the probability density of the surface with a height variation $z$ about a reference altitude $z_{0}$. Note that the second exponential term accounts for the volume propagation from the transmitter to the specular point, and from there to the volume scatterer at $\vec{R}$.

If $P\left(z^{\prime}, z_{0}\right)$ is assumed to be Gaussian distributed, i.e.

$$
P\left(z^{\prime}, z_{0}\right)=\frac{1}{\sqrt{2 \pi} \sigma_{z}} \cdot e^{\frac{-\left(z^{\prime}-z_{0}\right)^{2}}{2 \sigma_{z}^{2}}}
$$

where $\sigma_{z}$ is the standard deviation of surface vertical fluctuations, then the stationary phase method can be applied to (4.21), and one can obtain the following expression

$$
\begin{aligned}
& \left\langle\vec{E}_{\hat{t}_{1}}\left(\vec{R}, \omega_{0} ; \vec{R}_{s p e c}\right)\right\rangle=\frac{\left\langle\mathbf{R}\left(\theta_{\text {spec }}\right)\right\rangle \cdot \hat{t}_{1}}{\left|\vec{R}_{e 1}-\vec{R}_{s p e c}\right|+\left|\vec{R}-\vec{R}_{s p e c}\right|} \cdot e^{j k_{0}\left[\left|\vec{R}_{e 1}-\vec{R}_{s p e c}\right|+\left|\vec{R}-\vec{R}_{s p e c}\right|\right]} \\
& \cdot e^{\frac{j 2 \pi \rho_{0}\left\langle\hat{t} \cdot \mathbf{F}_{f} \cdot \hat{t}\right\rangle \cdot\left(h_{v}+z\right)}{k_{0} \cos \theta_{s p e c}}} \frac{1}{\sqrt{2 \pi} \sigma_{z}} \cdot \int_{-\infty}^{+\infty} e^{\frac{-\left(z^{\prime}-z_{0}\right)^{2}}{2 \sigma_{z}^{2}}-j 2 k_{0} \cdot \cos \theta_{s p e c}\left(z^{\prime}-z_{0}\right)} d z^{\prime} \approx \\
& \quad \approx \frac{1}{\left|\vec{R}_{e 1}-\vec{R}_{0}\right|} \cdot\left\langle\mathbf{R}\left(\theta_{\text {spec }}\right)\right\rangle \cdot \hat{t}_{1} \cdot \Gamma_{\text {rough }} \cdot e^{\left.j k_{0} \| \vec{R}_{e 1}-\vec{R}_{s p e c}|+| \vec{R}-\vec{R}_{s p e c} \mid\right]} \cdot e^{\frac{j 2 \pi \rho_{0}\left\langle\hat{t} \cdot \mathbf{F}_{f} \cdot \hat{t}\right\rangle \cdot\left(h_{v}+z\right)}{k_{0} \cos \theta_{s p e c}}}
\end{aligned}
$$


where the double bounce distance has been approximated by $\left|\vec{R}_{e 1}-\vec{R}_{0}\right|$. Here $\left\langle\mathbf{R}\left(\theta_{\text {spec }}\right)\right\rangle$ is the average ground reflection matrix, introduced in order to generalize the problem for arbitrary $\hat{t}_{1}$, which has the following form

$$
\mathbf{R}\left(\theta_{\text {spec }}\right)=\left(\begin{array}{cc}
R_{H}\left(\theta_{\text {spec }}\right) & 0 \\
0 & R_{V}\left(\theta_{\text {spec }}\right)
\end{array}\right)
$$

where $R_{H}$ and $R_{V}$ are the complex Fresnel reflection coefficients for horizontal and vertical polarizations, respectively.

In (4.23) ground roughness is described with $\Gamma_{\text {rough }}$ as [BS63]

$$
\Gamma_{\text {rough }}=e^{-2 k_{0}^{2} \sigma_{z}^{2} \cdot \cos \theta_{\text {spec }}}
$$

Once the contributions in expression (4.18) have been derived, the expression for the received field at $\vec{R}_{e 1}$ due to the ground-volume interaction is obtained by substituting in (4.19):

$$
\begin{aligned}
& \left\langle\vec{E}_{\hat{t}_{1}}^{\text {dihedral }_{G V}}\left(\vec{R}_{e 1}\right)\right\rangle=\frac{1}{\left|\vec{R}_{e 1}-\vec{R}_{0}\right|^{2}} \cdot \mathbf{F}_{\text {spec } \rightarrow \vec{R}_{e 1}} \cdot\left\langle\mathbf{R}\left(\theta_{\text {spec }}\right)\right\rangle \cdot \hat{t}_{1} \cdot \Gamma_{\text {rough }} \\
& e^{j k_{0}\left[\left|\vec{R}_{e 1}-\vec{R}_{s p e c}\right|+\left|\vec{R}-\vec{R}_{s p e c}\right|+\left|\vec{R}_{e 1}-\vec{R}\right|\right]} \cdot e^{\frac{j 4 \pi \rho_{0}\left\langle\hat{t} \cdot \mathbf{F}_{f} \cdot \hat{t}\right\rangle \cdot h_{v}}{k_{0} \cos \theta_{s p e c}}}
\end{aligned}
$$

The received signal at $\vec{R}_{e 1}$ resulting from the volume-ground interaction, $\left\langle\vec{E}_{\hat{t}_{1}}^{\text {dihedral }_{V G}}\left(\vec{R}_{e 1}\right)\right\rangle$, can be derived by using the direct field incident on $\vec{R}$ and expressed in (4.20). This field must be modified with the volume specular scattering matrix, $\mathbf{F}_{\vec{R}_{e 1} \rightarrow \text { spec }}$, and terms that account for the propagation path back to $\vec{R}_{e 1}$. According to this, the expression of the received signal for the volume-ground contribution is

$$
\begin{aligned}
& \left\langle\vec{E}_{\hat{t}_{1}}^{\text {dihedral }_{V G}}\left(\vec{R}_{e 1}\right)\right\rangle=\frac{1}{\left|\vec{R}_{e 1}-\vec{R}_{0}\right|^{2}} \cdot\left\langle\mathbf{R}\left(\theta_{\text {spec }}\right)\right\rangle \cdot \mathbf{F}_{\vec{R}_{e 1} \rightarrow \text { spec }} \cdot \hat{t}_{1} \cdot \Gamma_{\text {rough }} \cdot \\
& e^{j k_{0}\left[\left|\vec{R}_{e 1}-\vec{R}_{s p e c}\right|+\left|\vec{R}-\vec{R}_{s p e c}\right|+\left|\vec{R}_{e 1}-\vec{R}\right|\right]} \cdot e^{\frac{j 4 \pi \rho_{0}\left\langle\vec{t}_{f} \cdot \mathbf{F}_{f} \cdot \hat{t}\right\rangle \cdot h_{v}}{k_{0} \cos \theta_{s p e c}}}
\end{aligned}
$$

Finally, substituting in expression (4.15) gives the total backscattered field received at end 1 as

70

Tesis doctoral de la Universidad de Alicante. Tesi doctoral de la Universitat d'Alacant. 2007. 


$$
\begin{aligned}
& \left\langle\vec{E}_{\hat{t}_{1}}\left(\vec{R}_{e 1}, \omega_{0} ; \vec{R}\right)\right\rangle=\left\langle\vec{E}_{\hat{t}_{1}}^{\text {volume }}\left(\vec{R}_{e 1}\right)\right\rangle+\left\langle\vec{E}_{\hat{t}_{1}}^{\text {dihedral }_{G V}}\left(\vec{R}_{e 1}\right)\right\rangle+\left\langle\vec{E}_{\hat{t}_{1}}^{\text {dihedral }_{V G}}\left(\vec{R}_{e 1}\right)\right\rangle= \\
& =\frac{1}{\left|\vec{R}_{e 1}-\vec{R}_{0}\right|^{2}} \cdot \mathbf{F}_{b} \cdot \hat{t}_{1} \cdot e^{\left[j 2 k_{0}\left|\vec{R}_{e 1}-\vec{R}\right|+\frac{j 4 \pi \rho_{0}\left\langle\hat{t} \cdot \mathbf{F}_{f} \cdot \hat{t}\right\rangle \cdot\left(h_{y}-z\right)}{k_{0} \cos \theta_{\vec{R}}}\right]}+ \\
& +\frac{1}{\left|\vec{R}_{e 1}-\vec{R}_{0}\right|^{2}} \cdot \mathbf{F}_{\text {spec } \rightarrow \vec{R}_{e 1}} \cdot\left\langle\mathbf{R}\left(\theta_{s p e c}\right)\right\rangle \cdot \hat{t}_{1} \cdot \Gamma_{\text {rough }} \cdot e^{j k_{0}\left[\left|\vec{R}_{e 1}-\vec{R}_{s p e c}\right|+\left|\vec{R}-\vec{R}_{s p e c}\right|+\left|\vec{R}_{e 1}-\vec{R}\right|\right]} . \\
& \cdot e^{\frac{j 4 \pi \rho_{0}\left\langle\hat{t} \cdot \mathbf{F}_{f} \cdot \hat{t}\right\rangle \cdot h_{v}}{k_{0} \cos \theta_{\text {spec }}}}+ \\
& +\frac{1}{\left|\vec{R}_{e 1}-\vec{R}_{0}\right|^{2}} \cdot\left\langle\mathbf{R}\left(\theta_{\text {spec }}\right)\right\rangle \cdot \mathbf{F}_{\vec{R}_{e 1} \rightarrow \text { spec }} \cdot \hat{t}_{1} \cdot \Gamma_{\text {rough }} \cdot e^{j k_{0}\left[\left|\vec{R}_{e 1}-\vec{R}_{s p e c}\right|+\left|\vec{R}-\vec{R}_{s p e c}\right|+\left|\vec{R}_{e 1}-\vec{R}\right|\right]} . \\
& \cdot e^{\frac{j 4 \pi \rho_{0}\left\langle\hat{t} \cdot \mathbf{F}_{f} \cdot \hat{t}\right\rangle \cdot h_{v}}{k_{0} \cos \theta_{\text {spec }}}}
\end{aligned}
$$

From the previous expression, it can be defined a relationship that will be useful in the following lines:

$$
P_{1}(\vec{R})=\left|\vec{R}_{e 1}-\vec{R}_{s p e c}\right|+\left|\vec{R}-\vec{R}_{s p e c}\right|+\left|\vec{R}_{e 1}-\vec{R}\right| \approx 2\left|\vec{R}_{e 1}-\vec{R}\left(x, y, z_{0}\right)\right|
$$

As mentioned above, the interferometer works with a single transmitter located at end 1 (single-transmit mode), therefore the received field at end 2 , located at $\vec{R}_{e 2}$, and assuming that the transmitted polarization is $\hat{t}_{2}$, can be obtained from (4.28) as

$$
\begin{aligned}
& \left\langle\vec{E}_{\hat{t}_{2}}\left(\vec{R}_{e 2}, \omega_{0} ; \vec{R}\right)\right\rangle=\left\langle\vec{E}_{\hat{t}_{2}}^{\text {volume }}\left(\vec{R}_{e 2}\right)\right\rangle+\left\langle\vec{E}_{\hat{t}_{2}}^{\text {dihedral }_{G V}}\left(\vec{R}_{e 2}\right)\right\rangle+\left\langle\vec{E}_{\hat{t}_{2}}^{\text {dihedral }_{V G}}\left(\vec{R}_{e 2}\right)\right\rangle= \\
& \left.=\frac{1}{\left|\vec{R}_{e 1}-\vec{R}_{0}\right|^{2}} \cdot \mathbf{F}_{b} \cdot \hat{t}_{2} \cdot e^{\left[j k_{0}\left[\left|\vec{R}_{e 2}-\vec{R}\right|+\left|\vec{R}-\vec{R}_{e 2}\right|\right]+\frac{j 4 \pi \rho_{0}\left\langle\hat{t} \cdot \mathbf{F}_{f} \cdot \hat{t}\right\rangle \cdot\left(h_{v}-z\right)}{k_{0} \cos \theta \vec{R}}\right.}\right]_{+} \\
& +\frac{1}{\left|\vec{R}_{e 1}-\vec{R}_{0}\right|^{2}} \cdot \mathbf{F}_{\text {spec } \rightarrow \vec{R}_{e 1}} \cdot\left\langle\mathbf{R}\left(\theta_{\text {spec }}\right)\right\rangle \cdot \hat{t}_{2} \cdot \Gamma_{\text {rough }} \\
& \cdot e^{j k_{0}\left[P_{1}(\vec{R})+\left|\vec{R}_{e 2}-\vec{R}\right|-\left|\vec{R}_{e 1}-\vec{R}\right|\right]} \cdot e^{\frac{j 4 \pi \rho_{0}\left\langle\hat{i} \cdot \mathbf{F}_{f} \cdot \hat{t}\right\rangle \cdot h_{v}}{k_{0} \cos \theta_{s p e c}}}+ \\
& +\frac{1}{\left|\vec{R}_{e 1}-\vec{R}_{0}\right|^{2}} \cdot\left\langle\mathbf{R}\left(\theta_{\text {spec }}\right)\right\rangle \cdot \mathbf{F}_{\vec{R}_{e 1} \rightarrow \text { spec }} \cdot \hat{t}_{2} \cdot \Gamma_{\text {rough }} \cdot e^{j k_{0}\left[P_{2}(\vec{R})+\left|\vec{R}_{e 1}-\vec{R}_{2}\right|-\left|\vec{R}_{e 2}-\vec{R}\right|\right]} . \\
& \cdot e^{\frac{j 4 \pi \rho_{0}\left\langle\hat{t} \cdot \mathbf{F}_{f} \cdot \hat{t}\right\rangle \cdot h_{v}}{k_{0} \cos \theta_{s p e c}}}
\end{aligned}
$$

where it is assumed that $\left\langle\mathbf{R}\left(\theta_{\text {spec }}\right)\right\rangle$ and $\mathbf{F}_{\text {spec } \rightarrow \vec{R}_{e 1}}$ are the same values than for the specular point $\vec{R}_{\text {spec2 } 2}$. Besides, in the interferometric phase we define:

$$
P_{2}(\vec{R})=\left|\vec{R}_{e 2}-\vec{R}_{s p e c 2}\right|+\left|\vec{R}-\vec{R}_{s p e c 2}\right|+\left|\vec{R}_{e 2}-\vec{R}\right| \approx 2\left|\vec{R}_{e 2}-\vec{R}\left(x, y, z_{0}\right)\right|
$$


Next, the derivation of the cross correlation expression to be inserted in (4.14) is presented.

Taking the backscattered fields received at both ends of the baseline with polarizations $\hat{r}_{1}$ and $\hat{r}_{2}$, the cross correlation is obtained as in (4.32), where the labels $(V \star V),(G V \star G V)$, $(G V \star V G),(V G \star G V)$ and $(V G \star V G)$, have been used to indicate the cross products between each contribution to the total field (volume with volume, ground-volume with groundvolume, ground-volume with volume-ground, and so on):

$$
\begin{aligned}
& \left\langle\hat{r}_{1} \cdot \vec{E}_{\hat{t}_{1}}\left(\vec{R}_{e 1}, \omega_{0} ; \vec{R}\right) \cdot \hat{r}_{2}^{*} \cdot \vec{E}_{\hat{t}_{2}}^{*}\left(\vec{R}_{e 2}, \omega_{0} ; \vec{R}\right)\right\rangle=A^{4} \cdot e^{\frac{-2 \sigma_{x} h_{v}}{\cos \theta} \vec{R}} .
\end{aligned}
$$

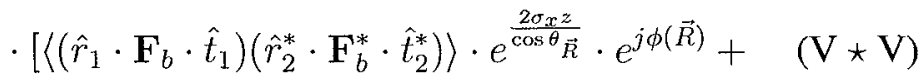

$$
\begin{aligned}
& +\Gamma_{\text {rough }}^{2}\left\langle\left(\hat{r}_{1} \cdot \mathbf{F}_{\text {spec } \rightarrow \vec{R}_{e 1}}\left\langle\mathbf{R}\left(\theta_{\text {spec }}\right)\right\rangle \cdot \hat{t}_{1}\right) \cdot\left(\hat{r}_{2}^{*} \cdot \mathbf{F}_{\text {spec } \rightarrow \vec{R}_{e 1}}\left\langle\mathbf{R}^{*}\left(\theta_{\text {spec }}\right)\right\rangle \cdot \hat{t}_{2}^{*}\right)\right\rangle \cdot e^{j \phi(\vec{R})} \\
& +\Gamma_{\text {rough }}^{2}\left\langle\left(\hat{r}_{1} \cdot \mathbf{F}_{\text {spec } \rightarrow \vec{R}_{e 1}}\left\langle\mathbf{R}\left(\theta_{\text {spec }}\right)\right\rangle \cdot \hat{t}_{1}\right) \cdot\left(\hat{r}_{2}^{*} \cdot\left\langle\mathbf{R}^{*}\left(\theta_{\text {spec }}\right)\right\rangle \mathbf{F}_{\vec{R}_{e 1} \rightarrow \text { spec }}^{*} \cdot \hat{t}_{2}^{*}\right)\right\rangle \cdot \\
& \cdot e^{j k_{0}\left[P_{1}(\vec{R})-P_{2}(\vec{R})\right]-j \phi(\vec{R})} \quad(\mathrm{GV} \star \mathrm{VG}) \\
& +\Gamma_{\text {rough }}^{2}\left\langle\left(\hat{r}_{1} \cdot\left\langle\mathbf{R}\left(\theta_{\text {spec }}\right)\right\rangle \cdot \mathbf{F}_{\vec{R}_{e 1} \rightarrow \text { spec }} \cdot \hat{t}_{1}\right) \cdot\left(\hat{r}_{2}^{*} \cdot \mathbf{F}_{\text {spec } \rightarrow \vec{R}_{e 1}}\left\langle\mathbf{R}^{*}\left(\theta_{\text {spec }}\right)\right\rangle \cdot \hat{t}_{2}^{*}\right)\right\rangle \cdot e^{j \phi(\vec{R})} \\
& (\mathrm{VG} \star \mathrm{GV}) \\
& +\Gamma_{\text {rough }}^{2}\left\langle\left(\hat{r}_{1} \cdot\left\langle\mathbf{R}\left(\theta_{\text {spec }}\right)\right\rangle \cdot \mathbf{F}_{\vec{R}_{e 1} \rightarrow \text { spec }} \cdot \hat{t}_{1}\right) \cdot\left(\hat{r}_{2}^{*} \cdot\left\langle\mathbf{R}^{*}\left(\theta_{\text {spec }}\right)\right\rangle \mathbf{F}_{\vec{R}_{e 1} \rightarrow \text { spec }}^{*} \cdot \hat{t}_{2}^{*}\right)\right\rangle \cdot \\
& \left.\cdot e^{j k_{0}\left[P_{1}(\vec{R})-P_{2}(\vec{R})\right]-j \phi(\vec{R})}\right]
\end{aligned}
$$

where $A=\frac{1}{\left|\vec{R}_{e 1}-\vec{R}_{0}\right|}$. In the first exponential term, shared by all the contributions, it appears an additional parameter to be estimated, i.e. the so-called extinction coefficient, $\sigma_{x}$, which is defined as

$$
\sigma_{x}=\frac{4 \pi \rho_{0} \Im\left(\left\langle\hat{r}_{1} \cdot \mathbf{F}_{f} \cdot \hat{t}_{1}\right\rangle\right)}{k_{0} \cos \theta_{0}}
$$

Note that this is a general definition and, hence, makes use of unitary vectors $\hat{t}_{1}$ and $\hat{r}_{1}$. Nevertheless, in the formulation shown previously the forward scattering matrix has been used as $\left\langle\hat{t} \cdot \mathbf{F}_{f} \cdot \hat{t}\right\rangle$ since a random volume was considered.

Moreover, the interferometric phase, $\phi(\vec{R})$, is defined in (4.32) as

$$
\phi(\vec{R})=k_{0}\left(\left|\vec{R}_{e 1}-\vec{R}\right|-\left|\vec{R}_{e 2}-\vec{R}\right|\right)=k_{0}\left(\left|\vec{r}_{1}\right|-\left|\vec{r}_{2}\right|\right) \equiv k_{0}\left(r_{1}-r_{2}\right)
$$

Note that unitary vector $\hat{r}_{1}$ corresponding to the received polarization must not be confused with vector $\vec{r}_{1}$, which accounts for the distance between end 1 of the baseline and $\vec{R}$. 
Next, a simplification of expression (4.32) is performed by means of the Taylor expansion of $\phi(\vec{R})$ about the reference point $\vec{R}_{0}$. Two types of partial derivatives are used, i.e. the range coordinate system $\left(r_{1}, z, \eta\right)$ for the volume term $(\mathrm{V} \star \mathrm{V})$, where $r_{1}$ is defined in $(4.34), z$ is the vertical dimension, and $\eta$ is the azimuth coordinate, and the rectangular coordinate system $(x, y, z)$ for the specular terms. A discussion about this issue is presented in [TS00, App.B].

The partial derivatives in the rectangular coordinates are

$$
\begin{aligned}
& \kappa_{x}=\left.k_{0}\left(\frac{\partial\left(r_{1}-r_{2}\right)}{\partial x}\right)_{y, z}\right|_{0}=\frac{k_{0} B \cos \left(\theta_{0}-\delta\right) \cos \theta_{0}}{r_{0}} \text { OClloll } \\
& \kappa_{y}=\left.k_{0}\left(\frac{\partial\left(r_{1}-r_{2}\right)}{\partial y}\right)_{x, z}\right|_{0}=\frac{k_{0} B \sin \left(\delta-\theta_{0}\right) \sin \theta_{0} \sin \eta_{0}}{r_{0}}=0, \text { taking } \eta_{0}=0 \\
& \kappa_{z}=\left.k_{0}\left(\frac{\partial\left(r_{1}-r_{2}\right)}{\partial z}\right)_{x, y}\right|_{0}=\frac{k_{0} B \sin \theta_{0} \cos \left(\theta_{0}-\delta\right)}{r_{0}}
\end{aligned}
$$

where $r_{0}=\left|\vec{R}_{e 1}-\vec{R}_{0}\right|$.

In the second case it is obtained

$$
\begin{aligned}
& \alpha_{r}=\left.k_{0}\left(\frac{\partial\left(r_{1}-r_{2}\right)}{\partial r_{1}}\right)_{z, \eta}\right|_{0}=\frac{k_{0} B \cos \left(\theta_{0}-\delta\right) \cos \theta_{0}}{r_{0} \sin \theta_{0}} \\
& \alpha_{z}=\left.k_{0}\left(\frac{\partial\left(r_{1}-r_{2}\right)}{\partial z}\right)_{r_{1}, \eta}\right|_{0}=\frac{k_{0} B \cos \left(\theta_{0}-\delta\right)}{r_{0} \sin \theta_{0}} \\
& \alpha_{\eta}=\left.k_{0}\left(\frac{\partial\left(r_{1}-r_{2}\right)}{\partial \eta}\right)_{r_{1}, z}\right|_{0}=-k_{0} B \sin \theta_{0} \sin \eta_{0} \cos \delta=0, \text { taking } \eta_{0}=0
\end{aligned}
$$

where $\delta$ corresponds to the angle between the baseline and the horizontal, and $\left.\right|_{0}$ indicates the evaluation at the reference point $\vec{R}_{0}$.

The first derivatives of the interferometric phase on the $z$ coordinate in the $(r, \eta, z)$ and $(x, y, z)$ coordinate systems, i.e. $\alpha_{z}$ and $\kappa_{z}$, respectively, correspond to the vertical wavenumbers for both coordinate systems. The necessity of maintaining $\alpha_{z}$ and $\kappa_{z}$ arises because the coordinate system used for calculating $\alpha_{z}$, i.e. $\left(r_{1}, \eta, z\right)$, is not an orthogonal system since $r_{1}$ depends on $z$. This is discussed in [TSO0, App.B].

Therefore, the interferometric phase can be approximated as

$$
\begin{aligned}
\phi(\vec{R})=\phi\left(\vec{R}\left(x_{0}, y_{0}, z_{0}\right)+\kappa_{x}\left(x-x_{0}\right)+\kappa_{y}(\right. & \left.\left.y-y_{0}\right)+\kappa_{z}\left(z-z_{0}\right)\right)= \\
& \left.=\phi\left(\vec{R}_{0}\right)+\kappa_{x}\left(x-x_{0}\right)+\kappa_{z}\left(z-z_{0}\right)\right)
\end{aligned}
$$


where the equivalence $\phi\left(\vec{R}_{0}\right) \equiv \phi_{0}$ will be used from here on to indicate the topographic phase.

According to the previous considerations, expression (4.32) can be rewritten as

$$
\begin{aligned}
& \left\langle\hat{r}_{1} \cdot \vec{E}_{\hat{t}_{1}}\left(\vec{R}_{e 1}, \omega_{0} ; \vec{R}\right) \cdot \hat{r}_{2}^{*} \cdot \vec{E}_{\hat{t}_{2}}^{*}\left(\vec{R}_{e 2}, \omega_{0} ; \vec{R}\right)\right\rangle=A^{4} \cdot e^{j \phi_{0}} \cdot e^{\frac{-2 \sigma_{x} h_{v}}{\cos \theta} \vec{R}} . \\
& \cdot\left[\left\langle\left(\hat{r}_{1} \cdot \mathbf{F}_{b} \cdot \hat{t}_{1}\right)\left(\hat{r}_{2}^{*} \cdot \mathbf{F}_{b}^{*} \cdot \hat{t}_{2}^{*}\right)\right\rangle \cdot e^{\frac{2 \sigma_{x} z}{\cos \theta_{\vec{R}}}} \cdot e^{j \alpha_{r}\left(r_{1}-r_{0}\right)+j \alpha_{z}\left(z-z_{0}\right)}\right](\mathrm{V} \star \mathrm{V}) \\
& +\Gamma_{\text {rough }}^{2}\left\langle\left(\hat{r}_{1} \cdot \mathbf{F}_{\text {spec } \rightarrow \vec{R}_{e 1}}\left\langle\mathbf{R}\left(\theta_{\text {spec }}\right)\right\rangle \cdot \hat{t}_{1}\right) \cdot\left(\hat{r}_{2}^{*} \cdot \mathbf{F}_{\text {spec } \rightarrow \vec{R}_{e 1}}\left\langle\mathbf{R}^{*}\left(\theta_{\text {spec }}\right)\right\rangle \cdot \hat{t}_{2}^{*}\right)\right\rangle \cdot \\
& \cdot e^{j \kappa_{x}\left(x-x_{0}\right)+j \kappa_{z}\left(z-z_{0}\right)} \quad(\mathrm{GV} \star \mathrm{GV}) \\
& +\Gamma_{\text {rough }}^{2}\left\langle\left(\hat{r}_{1} \cdot \mathbf{F}_{\text {spec } \rightarrow \vec{R}_{e 1}}\left\langle\mathbf{R}\left(\theta_{\text {spec }}\right)\right\rangle \cdot \hat{t}_{1}\right) \cdot\left(\hat{r}_{2}^{*} \cdot\left\langle\mathbf{R}^{*}\left(\theta_{\text {spec }}\right)\right\rangle \mathbf{F}_{\vec{R}_{e 1} \rightarrow \text { spec }}^{*} \cdot \hat{t}_{2}^{*}\right)\right\rangle \cdot \\
& \cdot e^{j \kappa_{x}\left(x-x_{0}\right)-j \kappa_{z}\left(z-z_{0}\right)} \quad(\mathrm{GV} \star \mathrm{VG}) \\
& +\Gamma_{\text {rough }}^{2}\left\langle\left(\hat{r}_{1} \cdot\left\langle\mathbf{R}\left(\theta_{\text {spec }}\right)\right\rangle \cdot \mathbf{F}_{\vec{R}_{e 1} \rightarrow \text { spec }} \cdot \hat{t}_{1}\right) \cdot\left(\hat{r}_{2}^{*} \cdot \mathbf{F}_{\text {spec } \rightarrow \vec{R}_{e 1}}^{*}\left\langle\mathbf{R}^{*}\left(\theta_{\text {spec }}\right)\right\rangle \cdot \hat{t}_{2}^{*}\right)\right\rangle \cdot \\
& \cdot e^{j \kappa_{x}\left(x-x_{0}\right)+j \kappa_{z}\left(z-z_{0}\right)} \quad(\mathrm{VG} \star \mathrm{GV}) \\
& +\Gamma_{\text {rough }}^{2}\left\langle\left(\hat{r}_{1} \cdot\left\langle\mathbf{R}\left(\theta_{\text {spec }}\right)\right\rangle \cdot \mathbf{F}_{\vec{R}_{e 1} \rightarrow \text { spec }} \cdot \hat{t}_{1}\right) \cdot\left(\hat{r}_{2}^{*} \cdot\left\langle\mathbf{R}^{*}\left(\theta_{\text {spec }}\right)\right\rangle \mathbf{F}_{\vec{R}_{e 1 \rightarrow s p e c}}^{*} \cdot \hat{t}_{2}^{*}\right)\right\rangle \cdot \\
& \left.\cdot e^{j \kappa_{x}\left(x-x_{0}\right)-j \kappa_{z}\left(z-z_{0}\right)}\right] \quad(\mathrm{VG} \star \mathrm{VG})
\end{aligned}
$$

Now, inserting expression (4.39) in (4.14), and taking into account that the integration in $x-y$ coordinates is equivalent to the $r-\eta$ integration, results in (note that notation for the received fields has been simplified to $\left.\vec{E}_{\hat{t}_{1,2}}\left(\vec{R}_{e(1,2)}\right)\right)$

$$
\begin{aligned}
& \left\langle\hat{r}_{1} \cdot \vec{E}_{\hat{t}_{1}}\left(\vec{R}_{e 1}\right) \cdot \hat{r}_{2}^{*} \cdot \vec{E}_{\hat{t}_{2}}^{*}\left(\vec{R}_{e 2}\right)\right\rangle=A^{4} \cdot e^{j \phi_{0}} \cdot e^{\frac{-2 \sigma_{x} h_{\nu}}{\cos \theta_{0}}} \cdot \int_{0}^{2 \pi} W_{\eta}^{2} d \eta \\
& \cdot \int_{-\infty}^{+\infty} W_{r}^{2} r_{0} e^{j \alpha_{r} r} d r \cdot \rho_{0} \cdot\left[\left\langle\left(\hat{r}_{1} \cdot \mathbf{F}_{b} \cdot \hat{t}_{1}\right)\left(\hat{r}_{2}^{*} \cdot \mathbf{F}_{b}^{*} \cdot \hat{t}_{2}^{*}\right)\right\rangle \cdot \int_{0}^{h_{v}} e^{\frac{2 \sigma_{x} z}{\cos \theta_{0}}+j \alpha_{z} z} d z \quad(\mathrm{~V} \star \mathrm{V})\right. \\
& +\Gamma_{\text {rough }}^{2}\left\langle\left(\hat{r}_{1} \cdot \mathbf{F}_{\text {spec } \rightarrow \vec{R}_{e 1}}\left\langle\mathbf{R}\left(\theta_{0}\right)\right\rangle \cdot \hat{t}_{1}\right) \cdot\left(\hat{r}_{2}^{*} \cdot \mathbf{F}_{\text {spec } \rightarrow \vec{R}_{e 1}}^{*}\left\langle\mathbf{R}^{*}\left(\theta_{0}\right)\right\rangle \cdot \hat{t}_{2}^{*}\right)\right\rangle \cdot \int_{0}^{h_{v}} e^{j \kappa_{z} z} d z \\
& (\mathrm{GV} \star \mathrm{GV}) \\
& +\Gamma_{\text {rough }}^{2}\left\langle\left(\hat{r}_{1} \cdot \mathbf{F}_{\text {spec } \rightarrow \vec{R}_{e 1}}\left\langle\mathbf{R}\left(\theta_{0}\right)\right\rangle \cdot \hat{t}_{1}\right) \cdot\left(\hat{r}_{2}^{*} \cdot\left\langle\mathbf{R}^{*}\left(\theta_{0}\right)\right\rangle \mathbf{F}_{\vec{R}_{e 1}^{*} \rightarrow \text { spec }} \cdot \hat{t}_{2}^{*}\right)\right\rangle \cdot \int_{0}^{h_{v}} e^{-j \kappa_{z} z} d z \\
& (\mathrm{GV} \star \mathrm{VG}) \\
& +\Gamma_{\text {rough }}^{2}\left\langle\left(\hat{r}_{1} \cdot\left\langle\mathbf{R}\left(\theta_{0}\right)\right\rangle \cdot \mathbf{F}_{\vec{R}_{e 1} \rightarrow \text { spec }} \cdot \hat{t}_{1}\right) \cdot\left(\hat{r}_{2}^{*} \cdot \mathbf{F}_{\text {spec } \rightarrow \vec{R}_{\mathrm{e} 1}}^{*}\left\langle\mathbf{R}^{*}\left(\theta_{0}\right)\right\rangle \cdot \hat{t}_{2}^{*}\right)\right\rangle \cdot \int_{0}^{h_{v}} e^{j \kappa_{z} z} d z \\
& (\mathrm{VG} \star \mathrm{GV}) \\
& \left.+\Gamma_{\text {rough }}^{2}\left\langle\left(\hat{r}_{1} \cdot\left\langle\mathbf{R}\left(\theta_{0}\right)\right\rangle \cdot \mathbf{F}_{\vec{R}_{e 1} \rightarrow \text { spec }} \cdot \hat{t}_{1}\right) \cdot\left(\hat{r}_{2}^{*} \cdot\left\langle\mathbf{R}^{*}\left(\theta_{0}\right)\right\rangle \mathbf{F}_{\vec{R}_{e 1} \rightarrow \text { spec }}^{*} \cdot \hat{t}_{2}^{*}\right)\right\rangle \cdot \int_{0}^{h_{v}} e^{-j \kappa_{z} z} d z\right] \\
& (\mathrm{VG} \star \mathrm{VG})
\end{aligned}
$$


where the incidence angle for each scattering element has been approximated by $\theta_{0}$. It must be noted that the phase associated with the specular terms is $\phi_{0}$, which is related to the ground height by means of $z_{0}=\phi_{0} / \kappa_{z}$. That is, the phase center of the double-bounce contributions is located at the ground surface.

The coherence expression can be obtained by normalizing expression (4.40), assuming a reciprocal medium, that is, $\mathbf{F}_{\vec{R}_{e 1} \rightarrow \text { spec }}=\mathbf{F}_{\text {spec } \rightarrow \vec{R}_{e 1}}$, and considering that the transmitted and received polarizations, $\hat{t_{1,2}}$ and $\hat{r_{1,2}}$, are denoted by arbitrary polarizations $\hat{t}$ and $\hat{r}$ for both ends of the baseline. In such a situation, averaged terms multiplying integrals can be reduced to a factor (see expression (4.42)) that contributes to the ground response in different ways depending upon the use of copolar or crosspolar polarization channels:

$$
\gamma_{\hat{r} \hat{t}}=\frac{\left\langle\hat{r} \cdot \vec{E}_{\hat{t}}\left(\vec{R}_{e 1}\right) \cdot \hat{r}^{*} \cdot \vec{E}_{\hat{t}}^{*}\left(\vec{R}_{e 2}\right)\right\rangle}{\sqrt{\left\langle\left|\hat{r} \cdot \vec{E}_{\hat{t}}\left(\vec{R}_{e 1}\right)\right|^{2}\right\rangle} \cdot \sqrt{\left\langle\left|\hat{r} \cdot \vec{E}_{\hat{t}}\left(\vec{R}_{e 2}\right)\right|^{2}\right\rangle}}=e^{j \phi_{0}} \cdot \frac{\int_{0}^{h_{v}} e^{\frac{2 \sigma z}{\cos \theta_{0}}+j \alpha_{z} z} d z+\mu_{\hat{r} \hat{t}} \cdot h_{v} \cdot \frac{\sin \left(\kappa_{z} h_{v}\right)}{\kappa_{z} h_{v}}}{\frac{\cos \theta_{0}}{2 \sigma_{x}} \cdot\left(e^{\frac{2 \sigma r h h_{v}}{\cos \theta_{0}}}-1\right)+\mu_{\hat{r} \hat{t}} \cdot h_{v}}
$$

where the scalar quantity accounting for the integration about the range coordinate has been cancelled. Parameter $\mu_{\hat{r} \hat{t}}$ is the product of the roughness loss, the reflection coefficient squared and the power of the specular to backscattered echoes, divided by the backscattering amplitude from the volume, and its expression is

$$
\mu_{\hat{r} \hat{t}}=4 \cdot \frac{\Gamma_{\text {rough }}^{2} \cdot\left\langle\vec{R}_{\hat{r} \hat{t}}\left(\theta_{0}\right)\right\rangle^{2} \cdot\left\langle\left|\hat{r} \cdot \mathbf{F}_{s p e c \rightarrow \vec{R}_{e 1}} \cdot \hat{t}\right|^{2}\right\rangle}{\left\langle\left|\hat{r} \cdot \mathbf{F}_{b} \cdot \hat{t}\right|^{2}\right\rangle}
$$

Parameter $\mu_{\hat{r} \hat{t}}$ is defined as the ground-to-volume ratio, which indicates the strength of the ground response related to the volume contribution, and it depends strongly on polarization because of the oriented nature of the ground surface.

Since the integral term in (4.41) has an analytical solution, the coherence expression for arbitrary polarizations $\hat{t}$ and $\hat{r}$ can be written as

$$
\gamma_{\hat{r} \hat{t}}=e^{j \phi_{0}} \cdot \frac{\frac{\frac{1}{2 \sigma_{x}}+j \alpha_{z}}{\cos \theta_{0}}+\left(e^{\left(\frac{2 \sigma_{x}}{\cos \theta_{0}}+j \alpha_{z}\right) h_{v}}-1\right)+\mu_{\hat{r} \hat{t}} \cdot h_{v} \cdot \frac{\sin \left(\kappa_{z} h_{v}\right)}{\kappa_{z} h_{v}}}{\frac{\cos \theta_{0}}{2 \sigma_{x}} \cdot\left(e^{\frac{2 \sigma_{x} h_{v}}{\cos \theta_{0}}}-1\right)+\mu_{\hat{r} \hat{t}} \cdot h_{v}}
$$

Finally, if both numerator and denominator are divided by the first term in denominator, named as $I_{0}$, expression (4.41) becomes

$$
\gamma_{\hat{r} \hat{t}}=e^{j \phi_{0}} \cdot \frac{\gamma_{v}+\frac{h_{v}}{I_{0}} \cdot \mu_{\hat{r} \hat{t}} \cdot \frac{\sin \left(\kappa_{z} h_{v}\right)}{\kappa_{z} h_{v}}}{1+\frac{h_{v}}{I_{0}} \cdot \mu_{\hat{r} \hat{t}}}
$$


where $\gamma_{v}$ is the volume coherence defined as

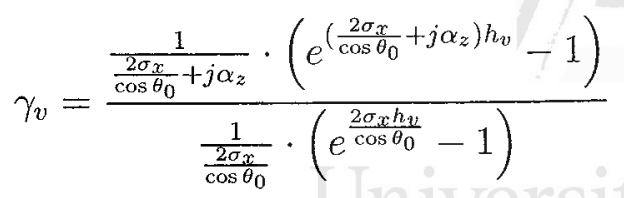

The interferometric coherence in expression $(4.43)$ is related to the biophysical parameters of the scene, i.e. $h_{v}, \phi_{0}\left(z_{0}\right), \sigma_{x}$ and $\mu_{\hat{r} \hat{t}}$, for arbitrary polarizations $\hat{t}$ and $\hat{r}$. In addition, note that Eq. (4.44) has been widely used in the literature [PCOI] by defining $m=\mu_{\hat{r} \hat{t}} / I_{0}$ as a different ground-to-volume ratio.

It is important to note that the sinc term appearing in $(4.43-4.44)$, that is directly generated by the specular contributions in a single-transmit acquisition mode, can be regarded as a bistatic volumetric decorrelation term. Note that since this model makes use of the Born approximation, the vertical profile varies exponentially, i.e. the propagation extinction is independent of height, and this generates a sinc function variation of coherence about the ground phase when the bistatic configuration is considered. Nevertheless, this behavior is due to the conjunction of the single-tx interferometer mode and the dominant double-bounce contribution from the ground, i.e. the sinc term does not appear when the ground response is dominated by direct surface scattering (not by double-bounce), even for the single-tx mode.

The reasons that explain the physics of the additional volumetric sinc term have to do with the assumptions concerning the propagation path for both ends of the baseline. On the one hand, identical wave extinction magnitudes (copolar channels) have been assumed for both ends, no matter the interferometric mode. On the other hand, different or identical phase shifts are introduced in the scattering contributions to the total field depending on the acquisition geometry. In single-transmit mode, the magnitudes of the cross-correlation of the double-bounce terms are identical (both correspond to the distance $h_{v} / \cos \theta_{0}$ ), but their phases are different. As a result, there appears a phase term distributed along the vertical axis at each component when computing the cross-correlation function (see integrands in expression (4.40)). The integration of these phase terms (with constant magnitude) along the vertical dimension produces the mentioned additional volumetric decorrelation term.

When operating in single-transmit mode and the cross-correlation of the double-bounce terms is computed their magnitudes, corresponding to the distance $h_{v} / \cos \theta_{0}$, remain identical but, instead, it is not the case of the phase terms. Accordingly, there appears a phase term contribution distributed along the vertical axis for each component of the cross-correlation function (see integrand terms in expression (4.40)). The integration of all this contributions in the vertical dimension results in the additional volumetric decorrelation term.

On the other hand, if a ping-pong mode is used, where two transmitters are positioned at both ends of the baseline, the propagation paths are constant for the the direct volume scattering as well as the specular signals, with expressions $2\left|\vec{R}_{e 1}-\vec{R}\right|$ and $2\left|\vec{R}_{e 2}-\vec{R}\right|$, respectively. As a result, $\kappa_{z}$ becomes 0 , i.e. there is not any phase contribution, and the integrand terms in (4.40) become 1 and, hence, each integral results in $h_{v}$. 
Additionally, note that the direct ground response does not generates the sinc term, even in the single-transmit mode, since it corresponds to a clearly localized scattering contribution, i.e. not to a vertically distributed target which is the one that induces the volumetric decorrelation effect when integrating its contributions.

According to the previous discussion, the general expression for the coherence is modified since the sinc term is not present any more, which corresponds to an absence of the bistatic volumetric decorrelation effect:

$$
\gamma_{\hat{r} \hat{t}}=e^{j \phi_{0}} \cdot \frac{\gamma_{v}+\frac{h_{v}}{I_{0}} \cdot \mu_{\hat{r} \hat{t}}}{1+\frac{h_{v}}{I_{0}} \cdot \mu_{\hat{r} \hat{t}}}
$$

Table 4.1 summarizes the total path lengths for each contribution depending on the working mode of the interferometer.

\begin{tabular}{|c|c|c|c|c|}
\hline & \multicolumn{2}{|c|}{ Single-transmit } & \multicolumn{2}{c|}{ Ping-pong } \\
\hline & End 1 & End 2 & End 1 & End 2 \\
\hline (V) & $2\left|\vec{R}_{e 1}-\vec{R}\right|$ & $\left|\vec{R}_{e 1}-\vec{R}\right|+\left|\vec{R}_{e 2}-\vec{R}\right|$ & $2\left|\vec{R}_{e 1}-\vec{R}\right|$ & $2\left|\vec{R}_{e 2}-\vec{R}\right|$ \\
\hline (G-V) & $P_{1}(\vec{R})$ & $P_{1}(\vec{R})-\left|\vec{R}_{e 1}-\vec{R}\right|+\left|\vec{R}_{e 2}-\vec{R}\right|$ & $P_{1}(\vec{R})$ & $P_{2}(\vec{R})$ \\
\hline (V-G) & $P_{1}(\vec{R})$ & $P_{1}(\vec{R})-\left|\vec{R}_{e 1}-\vec{R}_{s p e c}\right|+\left|\vec{R}_{e 2}-\vec{R}_{s p e c}\right|$ & $P_{1}(\vec{R})$ & $P_{2}(\vec{R})$ \\
\hline
\end{tabular}

Table 4.1: Total propagation paths depending on the working mode of the interferometer.

Figure 4.6 illustrates the loci of possible coherences on the complex plane as a function of the ground-to-volume ratio for a RVoG model corresponding to both single-tx and alternatetx modes, for a typical agricultural configuration with several combinations of extinctions and vegetation heights. Each solid line correspond to a different scene, and one can move along the line by changing the polarization channel, which in turn modifies the ground-tovolume ratio. The dashed line denotes the topographic phase $\phi_{0}$. The right column in Fig. 4.6 corresponds to the alternate-tx configuration, which is geometrically equivalent to a repeatpass interferometer. Therefore, the loci occupied by the coherences is the one appearing in the related literature so far $[\mathrm{PCO}, \mathrm{CPO}]$, which has been successfully employed for estimation of biophysical parameters of vegetation covers from air-borne radar data.

At the left column of the figure, when a single-tx configuration is used, the coherence loci are still lines but the aforementioned additional volumetric decorrelation term changes the position of these lines. In a single-tx scheme, even when the ground-to-volume ratio is infinite, one can not reach a unit coherence. This coherence decrease is produced by the differences in the travel paths of the double bounce contributions when returning to the receiving antennas, and they are always present although the direct volume return may be negligible.

The topographic phase is not represented anymore by the crossing between the line and 
the unit circumference and can be identified now by drawing a line from the origin to the coherence with infinite ground-to-volume ratio. The phase of this segment will be $\phi_{0}$. Evidently, the problem of this procedure is that one needs to measure at least one channel with a ground-to-volume ratio as high as possible. Note that, for the example in Fig. 4.6, changing the maximum ratio from 30 to $40 \mathrm{~dB}$ introduces more than 10 degrees of phase change in the estimation. Consequently, any future inversion approach derived from this model should take this change into account. In particular, the requirement of at least one channel with high $\mu$ is often met in agricultural scenarios, but not in forestry (even at L band), so the singletx configuration may be limited to short vegetation applications. On the other hand, from this point one can deduce that the alternate-tx mode is better suited for inversion purposes, and hence systems with two transmitters would be preferred, at the expense of increasing the hardware budget. Anyway, a deeper analysis on this topic is still needed before any definitive conclusion is stated. Note that together with the coherence decrease, a potential inversion approach based only on the geometry of the coherence loci as proposed in [CPO3] may not result straightforward. However, this would not be the case if a numerical method is used, since the number of unknowns does not increase and a regularization should be performed in order to obtain unambiguous solutions as in the alternate-tx case.

Next, a expression for the interferometric coherence of an oriented volume over ground considering the specular interaction will be derived in Section 4.3.2.

\subsubsection{Oriented volume over ground surface (OVoG)}

The term oriented volume addresses a vegetation layer which is composed by structures with a well defined orientation. Corn and rice plants (see Chapters 6 and 5) are two examples of this kind of vegetation. This feature makes the electromagnetic propagation to be anisotropic, i.e. the extinction coefficient depends on wave polarization. In fact, an electromagnetic wave will propagate through an oriented volume by means of two polarizations called eigenpolarizations [TKS85]. This concept relates the morphology of the oriented volume to the polarizations that physically can propagate through the vegetation, and means that a wave with an arbitrary polarization will change to an eigenpolarization as it travels into the volume. These polarization states can be orthogonal or non orthogonal depending on the medium characteristics, i.e. a homogeneous medium has two orthogonal eigenpolarizations whereas an inhomogeneous volume will have two non orthogonal propagation channels [LC94]. Note that in this thesis the propagated eigenpolarizations are assumed to be orthogonal because the vegetation volume is assumed to be homogeneous.

The concept of eigenpolarization is illustrated in Figure 4.7. Here, a vegetation layer basically composed by vertically oriented elements is considered. Therefore, the eigenpolarizations corresponding to this scenario are vertical and horizontal polarizations, which differ in the extinction coefficient value. The vertically polarized wave will suffer from the highest attenuation, whereas the horizontally polarized wave will penetrate more deeply along the volume. Nevertheless, this behaviour is highly frequency dependent, and both extinction coefficients tend to be equal as frequency increases [UTS87]. 


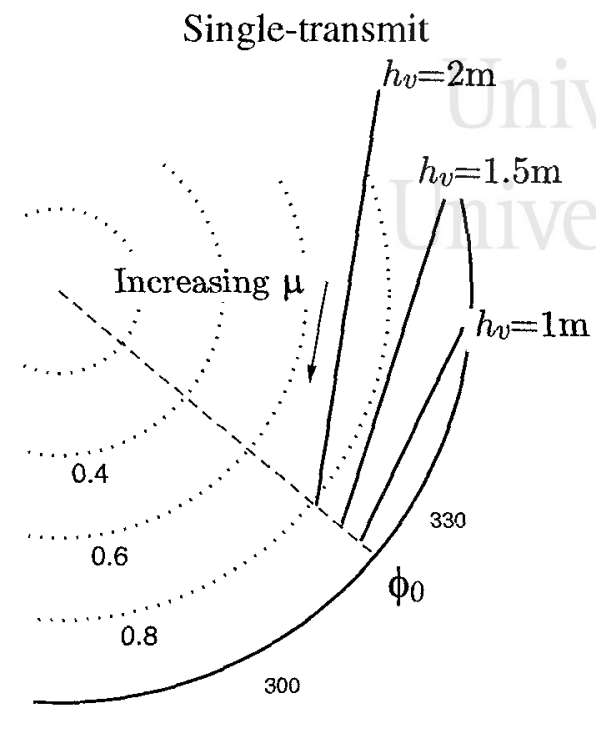

270

(a)

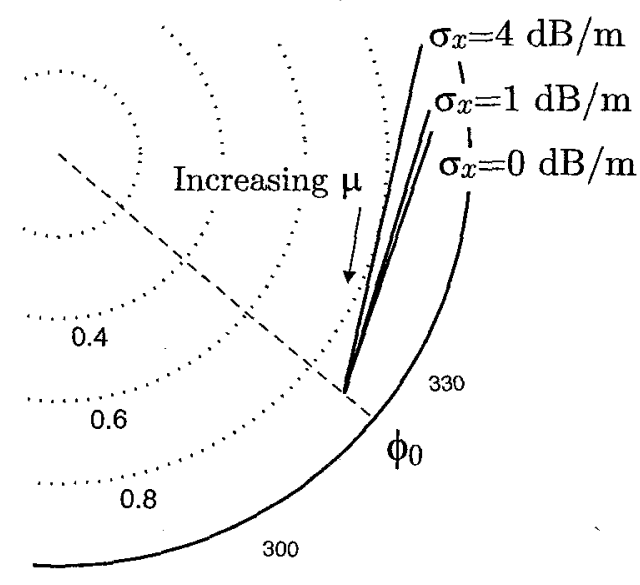

270

(c)
Alternate-transmit

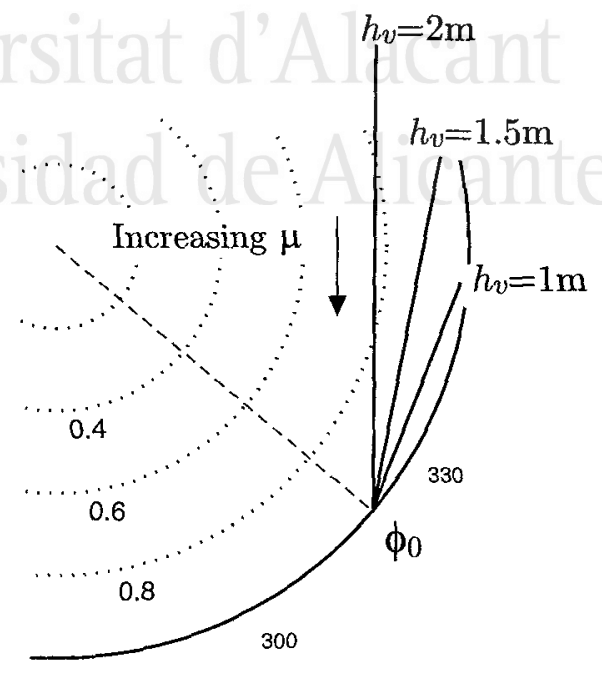

270

(b)

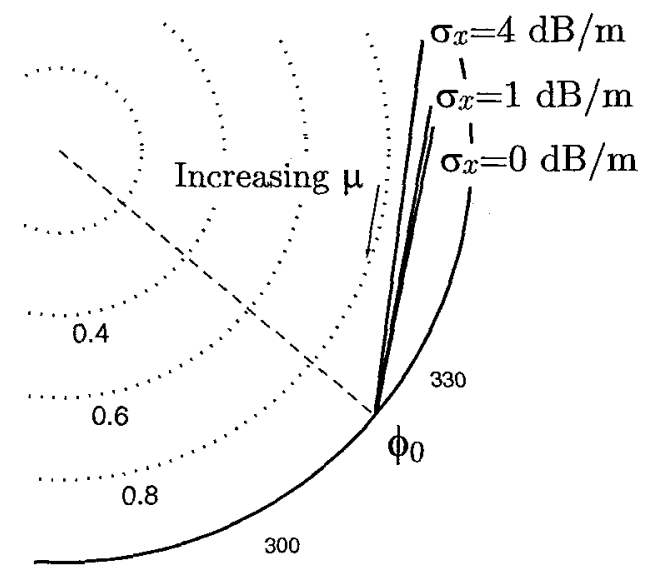

270

(d)

Figure 4.6: Loci of possible coherences of the RVoG model for single-tx (left) and alternate-tx (right) modes. Parameters: $\theta_{0}=45^{\circ}, \kappa_{z}=0.75, \phi_{0}=-40^{\circ},-40 \mathrm{~dB} \leq \mu_{\hat{r} \hat{t}} \leq+40 \mathrm{~dB}$. Cases: $(\mathrm{a}-\mathrm{b}) \sigma_{x}=1$ $\mathrm{dB} / \mathrm{m}, h_{v}=1,1.5$ and $2 \mathrm{~m}$; (c-d) $\sigma_{x}=0,1$ and $4 \mathrm{~dB} / \mathrm{m}, h_{v}=1.5 \mathrm{~m}$. 


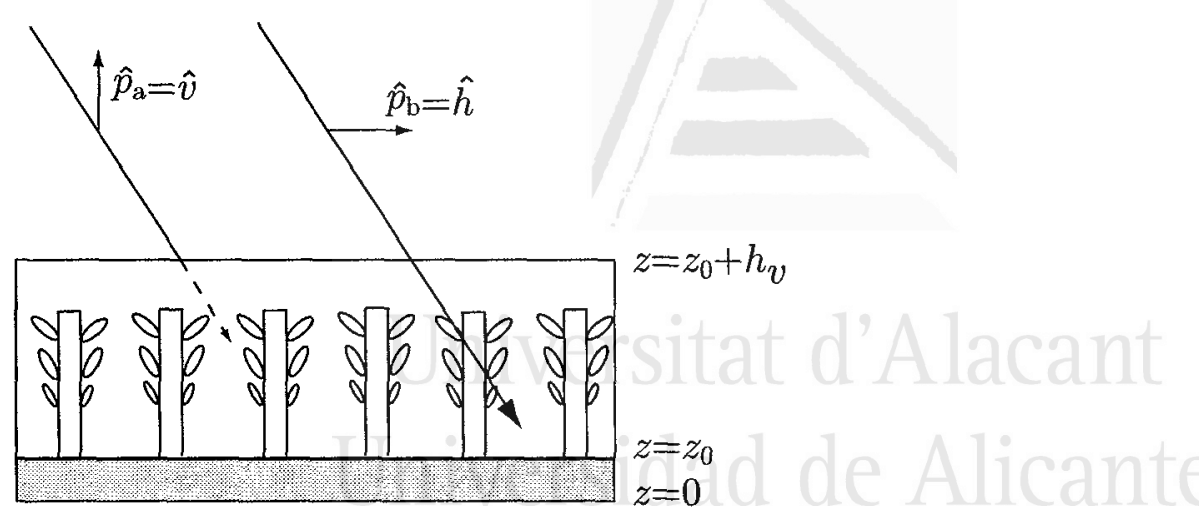

Figure 4.7: Wave propagation through an oriented volume.

Mathematically, the eigenpolarizations derive from the eigenanalysis of the average forward scattering matrix, $\left\langle\mathbf{F}_{f}\right\rangle$. In the oriented volume case, this matrix is not a multiple of the identity matrix any more. On the contrary, it is possible to apply an eigendecomposition [TKS85] on $\left\langle\mathbf{F}_{f}\right\rangle$, which results in

$$
\begin{aligned}
\left\langle\mathbf{F}_{f}\right\rangle & =\left[P_{\text {eigen }}\right] \cdot[\Lambda] \cdot\left[P_{\text {eigen }}\right]^{-1}=\left[P_{\text {eigen }}\right] \cdot\left(\begin{array}{cc}
\lambda_{a} & 0 \\
0 & \lambda_{b}
\end{array}\right) \cdot\left[P_{\text {eigen }}\right]^{-1} \\
& =\left(\begin{array}{ll}
\hat{p}_{a} & \hat{p}_{b}
\end{array}\right) \cdot\left(\begin{array}{cc}
\frac{k_{0}}{2 \pi \rho_{0}}\left(k_{0} \chi_{a}+j \frac{\sigma_{a}}{2}\right) & 0 \\
0 & \frac{k_{0}}{2 \pi \rho_{0}}\left(k_{0} \chi_{b}+j \frac{\sigma_{b}}{2}\right)
\end{array}\right) \cdot\left(\begin{array}{ll}
\hat{p}_{a} & \hat{p}_{b}
\end{array}\right)^{-1}
\end{aligned}
$$

where eigenvectors $\hat{p}_{a}$ and $\hat{p}_{b}$ correspond to the characteristic eigenpolarizations of the medium, and the non-zero elements of the diagonal matrix are the corresponding complex eigenvalues, $\lambda_{a}$ and $\lambda_{b}$, which are expressed as a function of the refractivity values, $\chi_{a}$ and $\chi_{b}$, and the extinction coefficients, $\sigma_{a}$ and $\sigma_{b}$, for each eigenpolarization.

The calculation of the cross correlation will make use of the projections of the transmitted and received fields on the eigenpolarizations, as it will be shown within the next lines.

As in the RVoG case, the total backscattered field for the OVoG (see Figure 4.5) obeys to the general expression in (4.15), where again the higher order scattering mechanisms have been discarded due to their negligible effect. Thus, for the sake of clarity, firstly the cross correlation expression for an oriented volume with no ground contribution will be derived. Later, this result will be extended to the OVoG case.

Firstly, the average field at scatterer at $\vec{R}$ due to the transmitter at $\vec{R}_{e 1}$ must be obtained. It is composed by two contributions, i.e. a direct signal from the transmitter and a coherent integration of all fields scattered from the elements inside the volume. It is written as 


$$
\begin{aligned}
\left\langle\vec{E}_{\hat{t}_{1}}\left(\vec{R}, \omega_{0} ; \vec{R}_{e 1}\right)\right\rangle=A \cdot \hat{t}_{1} \cdot e^{j k_{0} \cdot\left|\vec{R}-\vec{R}_{e 1}\right|}+ & \int_{\text {volume }} \rho_{0} \cdot \frac{e^{j k_{0} \cdot\left|\vec{R}^{\prime}-\vec{R}\right|}}{\left|\overrightarrow{R^{\prime}}-\vec{R}\right|} \cdot\left\langle\mathbf{F}_{\vec{R}_{e 1} \rightarrow \vec{R}^{\prime} \rightarrow \vec{R}}\right\rangle \cdot \\
& \cdot\left\langle\vec{E}_{\hat{t}_{1}}\left(\vec{R}^{\prime}, \omega_{0} ; \vec{R}_{e 1}\right)\right\rangle \cdot d^{3} R^{\prime}
\end{aligned}
$$

where $\left\langle\mathbf{F}_{\vec{R}_{e 1} \rightarrow \vec{R}^{\prime} \rightarrow \vec{R}}\right\rangle$ is the scattering matrix for a wave incident on a scatterer at $\vec{R}^{\prime}$ and scattered towards the scatterer at $\vec{R}$, and $\left\langle\vec{E}_{\hat{t}_{1}}\left(\vec{R}^{\prime}, \omega_{0} ; \vec{R}_{e 1}\right)\right\rangle$ represents the average direct field at $\vec{R}^{\prime}$ from end 1 of the baseline.

As indicated in [TSO0], the integral in (4.48) becomes a vector integral equation, and the method of stationary phase states that the solution can be expressed in terms of the forward scattering matrix and its associated eigenvectors, $\hat{p}_{a}$ and $\hat{p}_{b}$, assumed to be orthogonal $\left(\left\langle\mathbf{F}_{f}\right\rangle\right.$ is symmetric). Then, it can be written

$$
\begin{aligned}
& \left\langle\vec{E}_{\hat{t}_{1}}\left(\vec{R}, \omega_{0} ; \vec{R}_{e 1}\right)\right\rangle=\left(\left\langle\vec{E}_{\hat{t}_{1}}\left(\vec{R}, \omega_{0} ; \vec{R}_{e 1}\right)\right\rangle \cdot \hat{p}_{a}\right) \cdot \hat{p}_{a}+\left(\left\langle\vec{E}_{\hat{t}_{1}}\left(\vec{R}, \omega_{0} ; \vec{R}_{e 1}\right)\right\rangle \cdot \hat{p}_{b}\right) \cdot \hat{p}_{b}= \\
& =A \cdot e^{j k_{0} \cdot\left|\vec{R}-\vec{R}_{e 1}\right|}\left(\hat{t}_{1} \cdot \hat{p}_{a}\right) \cdot \hat{p}_{a}+ \\
& +\int_{\text {volume }} \rho_{0} \cdot \frac{e^{j k_{0} \cdot\left|\vec{R}^{\prime}-\vec{R}\right|}}{\left|\vec{R}^{\prime}-\vec{R}\right|} \cdot\left(\left\langle\mathbf{F}_{f}\right\rangle \cdot \hat{p}_{a}\right) \cdot\left\langle\vec{E}_{\hat{t}_{1}}\left(\vec{R}^{\prime}, \omega_{0} ; \vec{R}_{e 1}\right)\right\rangle \cdot \hat{p}_{a} \cdot d^{3} R^{\prime}+ \\
& +A \cdot e^{j k_{0} \cdot\left|\vec{R}-\vec{R}_{e 1}\right|}\left(\hat{t}_{1} \cdot \hat{p}_{b}\right) \cdot \hat{p}_{b}+ \\
& +\int_{\text {volume }} \rho_{0} \cdot \frac{e^{j k_{0} \cdot\left|\vec{R}^{\prime}-\vec{R}\right|}}{\left|\vec{R}^{\prime}-\vec{R}\right|} \cdot\left(\left\langle\mathbf{F}_{f}\right\rangle \cdot \hat{p}_{b}\right) \cdot\left\langle\vec{E}_{\hat{t}_{1}}\left(\vec{R}^{\prime}, \omega_{0} ; \vec{R}_{e 1}\right)\right\rangle \cdot \hat{p}_{b} \cdot d^{3} R^{\prime}
\end{aligned}
$$

Next, the application of the method of stationary phase on both integral terms yields the total average field incident at $\vec{R}$ :

$$
\begin{aligned}
\left\langle\vec{E}_{\hat{t}_{1}}\left(\vec{R}, \omega_{0} ; \vec{R}_{e 1}\right)\right\rangle & =A \cdot\left(\hat{t}_{1} \cdot \hat{p}_{a}\right) \cdot \hat{p}_{a} \cdot e^{j k_{0} \cdot\left|\vec{R}-\vec{R}_{e 1}\right|+\frac{j 2 \pi \rho_{0} \lambda_{a}\left(h_{v}-z\right)}{k_{0} \cdot \cos \theta_{\vec{R}}}}+ \\
& +A \cdot\left(\hat{t}_{1} \cdot \hat{p}_{b}\right) \cdot \hat{p}_{b} \cdot e^{j k_{0} \cdot\left|\vec{R}-\vec{R}_{e 1}\right|+\frac{j 2 \pi \rho_{0} \lambda_{b} \cdot\left(h_{v}-z\right)}{k_{0} \cdot \cos \theta_{\vec{R}}}}
\end{aligned}
$$

where $\lambda_{a}$ and $\lambda_{b}$ are the eigenvalues of the forward scattering matrix and were defined in (4.47).

Now, the received field at $\vec{R}_{e 1}$ is calculated by adding the contribution of the backscattering matrix $\mathbf{F}_{b}$, a free-space propagation term, and the influence of the oriented volume, accounted for by the integral term: 


$$
\begin{aligned}
\vec{E}_{\hat{t}_{1}}\left(\vec{R}_{e 1}, \omega_{0} ; \vec{R}\right) & =\frac{e^{j k_{0} \cdot\left|\vec{R}_{e 1}-\vec{R}\right|}}{\left|\vec{R}_{e 1}-\vec{R}\right|} \cdot \mathbf{F}_{b} \cdot\left\langle\vec{E}_{\hat{t}_{1}}\left(\vec{R}, \omega_{0} ; \vec{R}_{e 1}\right)\right\rangle+ \\
& +\int_{\text {volume }} \rho_{0} \cdot \frac{e^{j k_{0} \cdot\left|\vec{R}_{e 1}-\vec{R}^{\prime}\right|}}{\left|\vec{R}_{e 1}-\vec{R}^{\prime}\right|} \cdot\left\langle\mathbf{F}_{f}\right\rangle \cdot\left\langle\vec{E}_{\hat{t}_{1}}\left(\vec{R}^{\prime}, \omega_{0} ; \vec{R}\right)\right\rangle d^{3} R^{\prime}
\end{aligned}
$$

Then, substituting expression (4.50) in the first term and expressing the integral term as a function of the eigenpolarizations $\hat{p}_{i}$, with $i=a, b$, it can be rewritten:

$$
\begin{aligned}
\vec{E}_{\hat{t}_{1}}\left(\vec{R}_{e 1}, \omega_{0} ; \vec{R}\right) & \approx A^{2} \cdot e^{j 2 k_{0} \cdot\left|\vec{R}_{e 1}-\vec{R}\right|} \cdot \mathbf{F}_{b} \cdot \sum_{i}\left(\hat{t}_{1} \cdot \hat{p}_{i}\right) \cdot \hat{p}_{i} \cdot e^{\frac{j k_{0} x_{i}\left(h_{v}-z\right)}{\cos \theta_{\vec{R}}}-\frac{\sigma_{i}\left(h_{v}-z\right)}{2 \cos \vec{R}_{\vec{R}}}}+ \\
& +\int_{\text {volume }} \rho_{0} \cdot \frac{e^{j k_{0} \cdot\left|\vec{R}_{e 1}-\vec{R}^{\prime}\right|}}{\left|\vec{R}_{e 1}-\vec{R}^{\prime}\right|} \cdot\left\langle\mathbf{F}_{f}\right\rangle \cdot \sum_{l}\left(\hat{p}_{l} \cdot\left\langle\vec{E}_{\hat{t}_{1}}\left(\vec{R}^{\prime}, \omega_{0} ; \vec{R}\right)\right\rangle\right) \cdot \hat{p}_{l} d^{3} R^{\prime}= \\
& =A^{2} \cdot e^{j 2 k_{0} \cdot\left|\vec{R}_{e 1}-\vec{R}\right|} \cdot \sum_{l} \hat{p}_{l} \cdot \sum_{i}\left(\hat{t}_{1} \cdot \hat{p}_{i}\right) \cdot\left(\hat{p}_{l} \cdot \mathbf{F}_{b} \cdot \hat{p}_{i}\right) \cdot e^{\frac{j k_{0} x_{i}\left(h_{v}-z\right)}{\cos \theta_{\vec{R}}}-\frac{\sigma_{i}\left(h_{v}-z\right)}{2 \cos \vec{R}_{\vec{R}}}}+ \\
& +\int_{\text {volume }} \rho_{0} \cdot \frac{e^{j k_{0} \cdot\left|\vec{R}_{e 1}-\vec{R}^{\prime}\right|}}{\left|\vec{R}_{e 1}-\vec{R}^{\prime}\right|} \cdot \sum_{l} \lambda_{l} \cdot\left(\hat{p}_{l} \cdot\left\langle\vec{E}_{\hat{t}_{1}}\left(\vec{R}^{\prime}, \omega_{0} ; \vec{R}\right)\right\rangle\right) \cdot \hat{p}_{l} d^{3} R^{\prime}
\end{aligned}
$$

where the index $l=a, b$ has been also introduced. Substituting the integral by its equivalent expression, the received field at $\vec{R}_{e 1}$ is

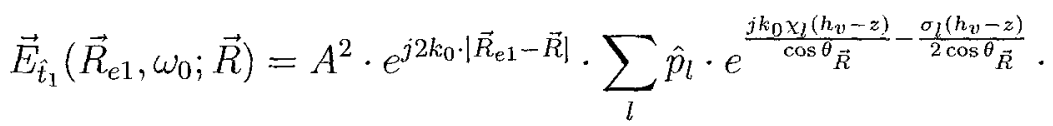

$$
\begin{aligned}
& \cdot \sum_{i}\left(\hat{t}_{1} \cdot \hat{p}_{i}\right) \cdot\left(\hat{p}_{l} \cdot \mathbf{F}_{b} \cdot \hat{p}_{i}\right) \cdot e^{\frac{j k_{0} x_{i}\left(h_{v}-z\right)}{\cos \theta_{\vec{R}}}-\frac{\sigma_{i}\left(h_{v}-z\right)}{2 \cos \theta_{\vec{R}}}}=
\end{aligned}
$$

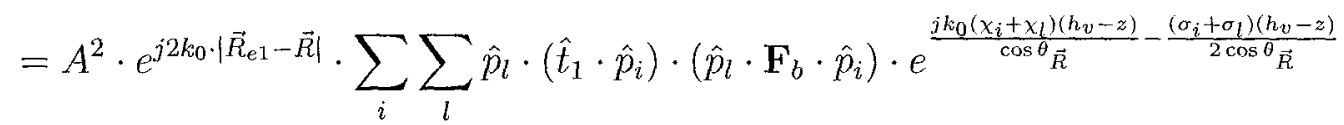

The received polarization at end 1 of the baseline is given by the projection of field in expression (4.53) on unitary vector $\hat{r}_{1}$ :

$$
\begin{aligned}
& \hat{r}_{1} \cdot \vec{E}_{\hat{t}_{1}}\left(\vec{R}_{e 1}, \omega_{0} ; \vec{R}\right)=A^{2} \cdot e^{j 2 k_{0} \cdot\left|\vec{R}_{e 1}-\vec{R}\right|} \cdot \sum_{i} \sum_{l}\left(\hat{r}_{1} \cdot \hat{p}_{i}\right) \cdot\left(\hat{t}_{1} \cdot \hat{p}_{l}\right) \cdot\left(\hat{p}_{i} \cdot \mathbf{F}_{b} \cdot \hat{p}_{l}\right) \\
& \cdot e^{\frac{j k_{0}\left(x_{i}+x_{i}\right)\left(h_{v}-z\right)}{\cos \theta} \vec{R}}-\frac{\left(\sigma_{i}+\sigma_{l}\right)\left(h_{y}-z\right)}{2 \cos \theta \vec{R}}
\end{aligned}
$$

82 
Next, expression (4.54) and its complex conjugate are inserted in the volume integral of (4.14) in order to calculate the cross correlation function, yielding:

$$
\begin{aligned}
& \left\langle\hat{r}_{1} \cdot \vec{E}_{\hat{t}_{1}}\left(\vec{R}_{e 1}\right) \cdot \hat{r}_{2}^{*} \cdot \vec{E}_{\hat{t}_{2}}^{*}\left(\vec{R}_{e 2}\right)\right\rangle=A^{4} \cdot e^{j \phi_{0}} \cdot \int W_{\eta}^{2} d \eta \cdot \int r_{0} W_{r}^{2} \cdot e^{j \alpha_{r} r} d r \\
& \cdot \int_{0}^{h_{v}} \rho_{0} e^{j \alpha_{z} z} \cdot \sum_{i, l, k, n}\left(\hat{r}_{1} \cdot \hat{p}_{i}\right) \cdot\left(\hat{t}_{1} \cdot \hat{p}_{l}\right) \cdot\left(\hat{r}_{2}^{*} \cdot \hat{p}_{k}^{*}\right) \cdot\left(\hat{t}_{2}^{*} \cdot \hat{p}_{n}^{*}\right) \cdot\left\langle\left(\hat{p}_{i} \cdot \mathbf{F}_{b} \cdot \hat{p}_{l}\right) \cdot\left(\hat{p}_{k}^{*} \cdot \mathbf{F}_{b}^{*} \cdot \hat{p}_{n}^{*}\right)\right\rangle \cdot \\
& \cdot e^{\frac{j k_{0}\left(\chi_{i}+\chi_{l}-\chi_{k}-\chi_{n}\right)\left(h_{v}-z\right)}{\cos \theta_{0}}} \cdot e^{-\frac{\left(\sigma_{i}+\sigma_{l}+\sigma_{k}+\sigma_{n}\right)\left(h_{v}-z\right)}{2 \cos \theta_{0}}}
\end{aligned}
$$

where $\theta_{\vec{R}}$ is approximated by $\theta_{0}$.

From (4.55) it can be observed that the calculation of the normalized cross correlation may result in an increase of the number of unknowns when the transmitted and received polarizations are not the eigenpolarizations. Nevertheless, our study is focused on vertically oriented vegetation covers with azimuthal symmetry and assuming a zero slope terrain, hence, in this particular case the eigenpolarizations correspond to $\hat{h}$ and $\hat{v}$ polarizations. Then, if the transmitted and received polarizations, $\hat{t}_{1,2}$ and $\hat{r}_{1,2}$, are assumed to be arbitrary eigenpolarizations as $\hat{t}_{e}$ and $\hat{r}_{e}$ representing $\hat{h}$ and $\hat{v}$ (or equivalently $\hat{p}_{a}$ and $\hat{p}_{b}$ ) the formulation for the coherence function can be simplified since both polarizations are orthogonal. Additionally, it is important to point out that the optimum coherences [CP98] for an oriented volume correspond to the eigenpolarizations $a a, a b$ and $b b$, as shown in [CPBO0]. This is specially useful when there is no a priori knowledge of the propagated polarizations, since the coherence optimization can be used to align the radar with the unknown eigenpolarization axis.

Therefore, calculating the inner products in $(4.55)$ for the terms accounting for the end 1 , which are denoted by indices $i, j$, and the end 2 , denoted by indices $k, l$, inside the integral along $z$, one obtains:

$$
\begin{aligned}
& \text { End } 1 \rightarrow \mathbf{F}_{b_{\hat{r}_{e} \hat{t}_{e}}} \cdot e^{\frac{j k_{0}\left(\chi_{a}+\chi_{b}\right)\left(h_{v}-z\right)}{\cos \theta_{0}}-\frac{\left(\sigma_{a}+\sigma_{b}\right)\left(h_{v}-z\right)}{2 \cos \theta_{0}}} \\
& \text { End } 2 \rightarrow \mathbf{F}_{b_{\hat{r}_{e}}}^{*} \cdot e^{\frac{-j k_{0}\left(\chi_{a}+\chi_{b}\right)\left(h_{v}-z\right)}{\cos \theta_{0}}-\frac{\left(\sigma_{a}+\sigma_{b}\right)\left(h_{v}-z\right)}{2 \cos \theta_{0}}}
\end{aligned}
$$

where

$$
\mathbf{F}_{b_{\hat{r}_{e} \hat{t}_{e}}}=\hat{r}_{e} \cdot \mathbf{F}_{b} \cdot \hat{t}_{e}
$$

Substituting this result in the integral of (4.55), it yields 


$$
\begin{aligned}
\left\langle\hat{r}_{e} \cdot \vec{E}_{\hat{t}_{e}}\left(\vec{R}_{e 1}\right) \cdot \hat{r}_{e}^{*} \cdot \vec{E}_{\hat{t}_{e}}^{*}\left(\vec{R}_{e 2}\right)\right\rangle & =A^{4} \cdot e^{j \phi_{0}} \cdot \int W_{\eta}^{2} d \eta \cdot \int r_{0} W_{r}^{2} \cdot e^{j \alpha_{r} r} d r \\
& \cdot \int_{0}^{h_{v}} \rho_{0} \cdot e^{j \alpha_{z} z} \cdot\left|\mathbf{F}_{b_{\hat{r}_{e}} \hat{t}_{e}}\right|^{2} \cdot e^{-\frac{\left(\sigma_{a}+\sigma_{b}\right)\left(h_{v}-z\right)}{\cos \theta_{0}}} d z
\end{aligned}
$$

In order to calculate the normalized cross correlation, the denominator of expression (4.58) must be obtained:

$$
\gamma=\frac{\left\langle\hat{r}_{e} \cdot \vec{E}_{\hat{t}_{e}}\left(\vec{R}_{e 1}\right) \cdot \hat{r}_{e}^{*} \cdot \vec{E}_{\hat{t}_{e}}^{*}\left(\vec{R}_{e 2}\right)\right\rangle}{\sqrt{\left\langle\left|\hat{r}_{e} \cdot \vec{E}_{\hat{t}_{e}}\left(\vec{R}_{e 1}\right)\right|^{2}\right\rangle} \cdot \sqrt{\left\langle\left|\hat{r}_{e} \cdot \vec{E}_{\hat{t}_{e}}\left(\vec{R}_{e 2}\right)\right|^{2}\right\rangle}}
$$

The expression for the normalizing factor in (4.58) has the same form than (4.57) but with the complex terms $e^{j \phi_{0}}$ and $e^{j \alpha_{z} z}$ removed:

$$
\begin{aligned}
\sqrt{\left\langle\left|\hat{r}_{e} \cdot \vec{E}_{\hat{t}_{e}}\left(\vec{R}_{e 1}\right)\right|^{2}\right\rangle} \cdot \sqrt{\left\langle\left|\hat{r}_{e} \cdot \vec{E}_{\hat{t}_{e}}\left(\vec{R}_{e 2}\right)\right|^{2}\right\rangle} & =A^{4} \cdot \int W_{\eta}^{2} d \eta \cdot \int r_{0} W_{r}^{2} \cdot e^{j \alpha_{r} r} d r . \\
& \cdot \int_{0}^{h_{v}} \rho_{0} \cdot\left|\mathbf{F}_{b_{\hat{r}_{e}} \hat{t}_{e}}\right|^{2} \cdot e^{-\frac{\left(\sigma_{a}+\sigma_{b}\right)\left(h_{v}-z\right)}{\cos \theta_{0}}} d z
\end{aligned}
$$

Finally, the expression for the complex interferometric coherence for an oriented volume, assuming that the transmitted and received polarizations are the eigenpolarizations is [Trog]

$$
\gamma=e^{j \phi_{0}} \cdot \frac{\int_{0}^{h_{v}} e^{j \alpha_{z} z} \cdot e^{-\frac{\left(\sigma_{a}+\sigma_{b}\right)\left(h_{v}-z\right)}{\cos \theta_{0}}} d z}{\int_{0}^{h_{v}} e^{-\frac{\left(\sigma_{a}+\sigma_{b}\right)\left(h_{v}-z\right)}{\cos \theta_{0}}} d z}
$$

Since integral terms in expression (4.60) have analytical solution, it can be written as

$$
\gamma_{v}=e^{j \phi_{0}} \cdot \frac{\frac{1}{\frac{\sigma_{a}+\sigma_{b}}{\cos \theta_{0}}+j \alpha_{z}} \cdot\left(e^{\left(\frac{\sigma_{a}+\sigma_{b}}{\cos \theta_{0}}+j \alpha_{z}\right) h_{v}}-1\right)}{\frac{1}{\frac{\sigma_{a}+\sigma_{b}}{\cos \theta_{0}}} \cdot\left(e^{\frac{\left(\sigma_{a}+\sigma_{b}\right) h_{v}}{\cos \theta_{0}}}-1\right)}
$$

which is known as the volume coherence function. Note that expression (4.61) has the same form that the normalized cross correlation for a random volume in the case of $\sigma_{a}=\sigma_{b}$ 
considering only the effect of the volume, i.e. a null value for the ground-to-volume ratio, $\mu_{\hat{r}_{e} \hat{t}_{e}} \cdot$

Now, we will use the previous considerations regarding the oriented volume and the random volume plus the ground-stem contribution in order to derive an expression for the oriented volume plus the effect introduced by the specular return, $\left\langle\vec{E}_{\hat{t}_{1}}^{\text {dihedral }}\right.$ GV $\left.\left(\vec{R}_{e 1}\right)\right\rangle$ and $\left\langle\vec{E}_{\hat{t}_{1}}^{\text {dihedral }}\right.$ VG $\left._{V}\left(\vec{R}_{e 1}\right)\right\rangle$. Once these two contributions have been calculated, the total field calculated, the total field at $\vec{R}_{e 1}$ (and at $\vec{R}_{e 2}$ ) by the general expression in (4.15).

Replicating the procedure described in Section 4.3.1 from equations (4.18) to (4.26), and taking into account that the expression for the received field on the volume scatterer at $\vec{R}$ is given by ( 4.50$)$, the total field at that point can be written as

$$
\begin{aligned}
& \left\langle\vec{E}_{\hat{t}_{1}}\left(\vec{R}, \omega_{0} ; \vec{R}_{s p e c}\right)\right\rangle=\frac{\left\langle\mathbf{R}\left(\theta_{\text {spec }}\right)\right\rangle}{\left|\vec{R}_{e 1}-\vec{R}_{s p e c}\right|+\left|\vec{R}-\vec{R}_{s p e c}\right|} \cdot e^{j k_{0}\left[\left|\vec{R}_{e 1}-\vec{R}_{s p e c}\right|+\left|\vec{R}-\vec{R}_{s p e c}\right| l\right.} . \\
& \cdot\left[\left(\hat{t}_{1} \cdot \hat{p}_{a}\right) \cdot \hat{p}_{a} \cdot e^{\frac{j 2 \pi \rho_{0} \lambda_{a}\left(h_{v}+z\right)}{\hat{k}_{0} \cos \theta_{0}}}+\left(\hat{t}_{1} \cdot \hat{p}_{b}\right) \cdot \hat{p}_{b} \cdot e^{\frac{j 2 \pi \rho_{0} \lambda_{b}\left(h_{v}+z\right)}{k_{0} \cos \theta_{0}}}\right] . \\
& \frac{1}{\sqrt{2 \pi} \sigma_{z}} \int_{-\infty}^{+\infty} e^{\frac{-\left(z^{\prime}-z_{0}\right)^{2}}{2 \sigma_{z}^{2}}-j 2 k_{0} \cdot \cos \theta_{0}\left(z^{\prime}-z_{0}\right)} d z^{\prime} \approx \\
& \approx A \cdot\left\langle\mathbf{R}\left(\theta_{\text {spec }}\right)\right\rangle \cdot \Gamma_{\text {rough }} \cdot e^{j k_{0}\left[\left|\vec{R}_{e 1}-\vec{R}_{s p e c}\right|+\left|\vec{R}-\vec{R}_{s p e c}\right|\right]} . \\
& \cdot\left[\left(\hat{t}_{1} \cdot \hat{p}_{a}\right) \cdot \hat{p}_{a} \cdot e^{\frac{j 2 \pi \rho_{0} \lambda_{a}\left(h_{v}+z\right)}{k_{0} \cos \theta_{0}}}+\left(\hat{t}_{1} \cdot \hat{p}_{b}\right) \cdot \hat{p}_{b} \cdot e^{\frac{j 2 \pi \rho_{0} \lambda_{b}\left(h_{v}+z\right)}{k_{0} \cos \theta_{0}}}\right]
\end{aligned}
$$

where $\lambda_{a}$ and $\lambda_{b}$ were defined in (4.47).

Next, following the same indications for the expression (4.51), the incident field at $\vec{R}$ must be multiplied by the volume specular matrix, $\mathbf{F}_{\text {spec } \rightarrow \vec{R}_{e 1}}$, and a free-space propagation term, and the effect of the volume must be added. Thus,

$$
\begin{aligned}
& \left\langle\vec{E}_{\hat{t}_{1}}^{\text {inhedral }_{G V}}\left(\vec{R}_{e 1}\right)\right\rangle=\frac{e^{j k_{0} \cdot\left|\vec{R}_{e 1}-\vec{R}\right|}}{\left|\vec{R}_{e 1}-\vec{R}\right|} \cdot \mathbf{F}_{\text {spec } \rightarrow \vec{R}_{e 1}} \cdot\left\langle\vec{E}_{\hat{t}_{1}}\left(\vec{R}, \omega_{0} ; \vec{R}_{e 1}\right)\right\rangle+ \\
& +\int_{\text {volume }} \rho_{0} \cdot \frac{e^{j k_{0} \cdot\left|\vec{R}_{e 1}-\vec{R}^{\prime}\right|}}{\left|\vec{R}_{e 1}-\vec{R}^{\prime}\right|} \cdot\left\langle\mathbf{F}_{\vec{R} \rightarrow \vec{R}^{\prime} \rightarrow \vec{R}_{e 1}}\right\rangle \cdot\left\langle\vec{E}_{\hat{t}_{1}}\left(\vec{R}^{\prime}, \omega_{0} ; \vec{R}\right)\right\rangle d^{3} R^{\prime}
\end{aligned}
$$

where $\left\langle\mathbf{F}_{\vec{R} \rightarrow \vec{R}^{\prime} \rightarrow \vec{R}_{e 1}}\right\rangle$ is the scattering matrix for a wave coming from $\vec{R}$ and impinging on a scatterer at $\vec{R}^{\prime}$ and scattered scattered towards $\vec{R}_{e 1}$, and $\left.\left\langle\vec{E}_{\hat{t}_{1}} \omega_{0} ; \vec{R}\right)\right\rangle$ represents the average field at $\vec{R}^{\prime}$ from a volume scatterer at $\vec{R}$.

Again, the main contribution in the volume integral comes from the forward scattering matrix $\left\langle\mathbf{F}_{f}\right\rangle$, and then, the integral can be expressed in terms of the eigenpolarizations and eigenvalues associated with that matrix: 


$$
\begin{aligned}
\left\langle\vec{E}_{\hat{t}_{1}}^{\text {dihedral }_{G V}}\left(\vec{R}_{e 1}\right)\right\rangle= & A^{2} \cdot e^{j k_{0} \cdot\left[\left|\vec{R}_{e 1}-\vec{R}_{s p e c}\right|+\left|\vec{R}-\vec{R}_{s p e c}\right|+\left|\vec{R}_{e 1}-\vec{R}\right|\right]} \cdot \mathbf{F}_{s p e c \rightarrow \vec{R}_{e 1}} \cdot\left\langle\mathbf{R}\left(\theta_{\text {spec }}\right)\right\rangle \cdot \Gamma_{\text {rough }} . \\
& \cdot\left[\left(\hat{t}_{1} \cdot \hat{p}_{a}\right) \cdot \hat{p}_{a} \cdot e^{\frac{j 2 \pi \rho_{0} \lambda_{a}\left(h_{\nu}+z\right)}{k_{0} \cos \theta_{0}}}+\left(\hat{t}_{1} \cdot \hat{p}_{b}\right) \cdot \hat{p}_{b} \cdot e^{\frac{j 2 \pi \rho_{0} \lambda_{b}\left(h_{\nu}+z\right)}{k_{0} \cos \theta_{0}}}\right]+ \\
& +\int_{\text {volume }} \rho_{0} \cdot \frac{e^{j k_{0}\left|\vec{R}_{e 1}-\vec{R}^{\prime}\right|}}{\left|\vec{R}_{e 1}-\vec{R}^{\prime}\right|} \cdot \sum_{l} \lambda_{l} \cdot\left(\hat{p}_{l} \cdot\left\langle\vec{E}_{\hat{t}_{1}}\left(\vec{R}^{\prime}, \omega_{0} ; \vec{R}\right)\right\rangle\right) \cdot \hat{p}_{l} d^{3} R^{\prime} \partial
\end{aligned}
$$

Substituting the equivalent expressions as in the oriented volume case (see equations (4.52) and (4.53)) gives

$$
\begin{aligned}
& \left\langle\vec{E}_{\hat{t}_{1}}^{\text {dihedral } l_{G V}}\left(\vec{R}_{e 1}\right)\right\rangle=A^{2} \cdot e^{j k_{0} \cdot\left[\left|\vec{R}_{e 1}-\vec{R}_{s p e c}\right|+\left|\vec{R}-\vec{R}_{s p e c}\right|+\left|\vec{R}_{e 1}-\vec{R}\right|\right]} \cdot \Gamma_{r o u g h} \cdot \\
& \cdot \sum_{l} \hat{p}_{l} \cdot e^{\frac{j k_{0} \chi_{l}\left(h_{v}+z\right)}{\cos \theta_{0}}-\frac{\sigma_{l}\left(h_{v}+z\right)}{2 \cos \theta_{0}}} \cdot \sum_{i}\left(\hat{t}_{1} \cdot \hat{p}_{i}\right) \cdot\left(\hat{p}_{l} \cdot \mathbf{F}_{s p e c \rightarrow \vec{R}_{e 1}} \cdot\left\langle\mathbf{R}\left(\theta_{s p e c}\right)\right\rangle \cdot \hat{p}_{i}\right) \cdot \\
& \cdot e^{\frac{j k_{0} \chi_{i}\left(h_{v}-z\right)}{\cos \theta_{0}}-\frac{\sigma_{i}\left(h_{v}-z\right)}{2 \cos \theta_{0}}}= \\
& =A^{2} \cdot e^{\left.j k_{0} \cdot\left[\left|\vec{R}_{e 1}-\vec{R}_{s p e c}\right|+\left|\vec{R}-\vec{R}_{s p e c}\right|+\mid \vec{R}_{e 1}-\vec{R}_{\|}\right]\right]} \cdot \Gamma_{\text {rough }} \cdot \\
& \cdot \sum_{i} \sum_{l} \hat{p}_{l} \cdot\left(\hat{t}_{1} \cdot \hat{p}_{i}\right) \cdot\left(\hat{p}_{l} \cdot \mathbf{F}_{s p e c \rightarrow \vec{R}_{e 1}} \cdot\left\langle\mathbf{R}\left(\theta_{s p e c}\right)\right\rangle \cdot \hat{p}_{i}\right) \cdot e^{\frac{\left.j k_{0} \mid\left(\chi_{i}+\chi_{l}\right) h_{v}-\left(\chi_{i}-\chi_{l}\right) z\right]}{\cos \theta_{0}}} . \\
& \cdot e^{-\frac{\left(\sigma_{i}+\sigma_{l}\right) h_{v}-\left(\sigma_{i}-\sigma_{l}\right) z}{2 \cos \theta_{0}}}
\end{aligned}
$$

The field due to the volume-ground contribution can be obtained in the same way than the ground-volume term taking into account that the order of occurrence of scattering mechanisms must be interchanged and that now the volume specular matrix is $\mathbf{F}_{\vec{R}_{e 1} \rightarrow \text { spec }}$. Comparing with the ground-volume case, a similar expression is derived:

$$
\begin{aligned}
& \left\langle\vec{E}_{\hat{t}_{1}}^{\text {dihedral }_{V G}}\left(\vec{R}_{e 1}\right)\right\rangle=A^{2} \cdot e^{\left.j k_{0} \cdot\left[\left|\vec{R}_{e 1}-\vec{R}\right|+\left|\vec{R}-\vec{R}_{s p e c}\right|+\mid \vec{R}_{e 1}-\vec{R}_{s p e c}\right]\right]} \cdot \Gamma_{\text {rough }} \cdot \\
& \cdot \sum_{i} \sum_{l} \hat{p}_{l} \cdot\left(\hat{t}_{1} \cdot \hat{p}_{i}\right) \cdot\left(\hat{p}_{l} \cdot\left\langle\mathbf{R}\left(\theta_{\text {spec }}\right)\right\rangle \cdot \mathbf{F}_{\vec{R}_{e 1} \rightarrow \text { spec }} \cdot \hat{p}_{i}\right) \cdot e^{\frac{j k_{0}\left[\left(x_{i}+\chi_{l}\right) h_{v}+\left(\chi_{i}-\chi_{l}\right) z\right]}{\cos \theta_{0}}} \cdot \\
& \cdot e^{-\frac{\left(\sigma_{i}+\sigma_{l}\right) h_{v}+\left(\sigma_{i}-\sigma_{l}\right) z}{2 \cos \theta_{0}}}
\end{aligned}
$$

Therefore, the total field received at $\vec{R}_{e 1}$ is given by 


$$
\begin{aligned}
& \left\langle\vec{E}_{\hat{t}_{1}}\left(\vec{R}_{e 1}, \omega_{0} ; \vec{R}\right)\right\rangle=\left\langle\vec{E}_{\hat{t}_{1}}^{\text {volume }}\left(\vec{R}_{e 1}\right)\right\rangle+\left\langle\vec{E}_{\hat{t}_{1}}^{\text {dihedral }_{G V}}\left(\vec{R}_{e 1}\right)\right\rangle+\left\langle\vec{E}_{\hat{t}_{1}}^{\text {dinedral }_{V} G}\left(\vec{R}_{e 1}\right)\right\rangle= \\
& =A^{2} \cdot\left[e^{j 2 k_{0}\left|\vec{R}_{e 1}-\vec{R}\right|} \cdot \sum_{i} \sum_{l} \hat{p}_{l} \cdot\left(\hat{t}_{1} \cdot \hat{p}_{i}\right) \cdot\left(\hat{p}_{l} \cdot \mathbf{F}_{b} \cdot \hat{p}_{i}\right) \cdot e^{\frac{j k_{0}\left(x_{i}+\chi_{l}\right)\left(h_{v}-z\right)}{\cos \theta \vec{R}}-\frac{\left(\sigma_{i}+\sigma_{l}\right)\left(h_{v}-z\right)}{2 \cos \theta} \vec{R}}+\right. \\
& +e^{j k_{0} P_{\mathbf{1}}(\vec{R})} \cdot \Gamma_{\text {rough }} \cdot \sum_{i} \sum_{l} \hat{p}_{l} \cdot\left(\hat{t}_{1} \cdot \hat{p}_{i}\right) \cdot\left(\hat{p}_{l} \cdot \mathbf{F}_{s p e c \rightarrow \vec{R}_{e 1}} \cdot\left\langle\mathbf{R}\left(\theta_{\text {spec }}\right)\right\rangle \cdot \hat{p}_{i}\right) . \\
& \cdot e^{\frac{j k_{0}\left[\left(\chi_{i}+\chi_{l}\right) h_{v}-\left(\chi_{i}-\chi_{l}\right) z\right]}{\cos \theta_{0}}} \cdot e^{-\frac{\left(\sigma_{i}+\sigma_{l}\right) h_{v}-\left(\sigma_{i}-\sigma_{l}\right) z}{2 \cos \theta_{0}}}+ \\
& +e^{j k_{0} P_{1}(\vec{R})} \cdot \Gamma_{\text {rough }} \cdot \sum_{i} \sum_{l} \hat{p}_{l} \cdot\left(\hat{t}_{1} \cdot \hat{p}_{i}\right) \cdot\left(\hat{p}_{l} \cdot\left\langle\mathbf{R}\left(\theta_{\text {spec }}\right)\right\rangle \cdot \mathbf{F}_{\vec{R}_{e 1} \rightarrow \text { spec }} \cdot \hat{p}_{i}\right) \text {. } \\
& \cdot e^{\frac{j k_{0}\left[\left(\chi_{i}+\chi_{l}\right) h_{v}+\left(\chi_{i}-\chi_{l}\right) z\right]}{\cos \theta_{0}}} \cdot e^{\left.-\frac{\left(\sigma_{i}+\sigma_{l}\right) h_{v}+\left(\sigma_{i}-\sigma_{l}\right) z}{2 \cos \theta_{0}}\right]}
\end{aligned}
$$

Now, expression (4.67) can be replicated to calculate $\left\langle\vec{E}_{\hat{t}_{2}}\left(\vec{R}_{e 2}, \omega_{0} ; \vec{R}\right)\right\rangle$ where the ground scattering matrix, $\left\langle\mathbf{R}\left(\theta_{\text {spec }}\right)\right\rangle$, and the volume scattering matrix, $\mathbf{F}_{\text {spec } \rightarrow \vec{R}_{\mathrm{e} 1}}$, are assumed to be equal to the corresponding ground reflection point for the end 2 . Then, its expression is obtained by changing to 2 the subscript of unitary and position vectors.

It is important to note that if both expressions for the received field are used to calculate the cross correlation function, the interferometric phase terms remain unchanged when compared to the RVoG case. Differences appear on the summatory terms accounting for the propagation through the oriented volume. These summatories generate four terms in the most general case, which involves sixteen cross terms when the complex conjugate product is computed. However, as it was mentioned previously, one can assume that the transmitted and received polarizations used are the eigenpolarizations and, as a consequence, the cross terms in (4.67) are simplified. Indeed, the only non-zero combinations correspond to $i=a, l=a, i=a, l=b$, or $i=b, l=b$. In addition, since a reciprocal medium is assumed, the ensemble average values considering the volume and the ground scattering matrices become the same (represented by $\left(\mathbf{F} \star \mathbf{R}\left(\theta_{\text {spec }}\right)\right)$ ). According to this, and considering an arbitrary eigenpolarizations $\hat{t}_{e}$ and $\hat{r}_{e}$, the terms (some constants are not included) to be inserted in the volume integral of (4.14) are the following ones: 


$$
\begin{aligned}
(\mathrm{V} \star \mathrm{V}) & \left|\mathbf{F}_{b_{\hat{r}_{e} \hat{t}_{e}}}\right|^{2} \cdot e^{-\frac{\left(\sigma_{a}+\sigma_{b}\right)\left(h_{v}-z\right)}{\cos \theta_{0}}} \\
(\mathrm{GV} \star \mathrm{GV}) & \Gamma_{\text {rough }}^{2} \cdot\left(\mathbf{F} \star \mathbf{R}\left(\theta_{\text {spec }}\right)\right) \cdot e^{-\frac{\left(\sigma_{a}+\sigma_{b}\right) h_{v}}{\cos \theta_{0}}} \cdot e^{\frac{\left(\sigma_{a}-\sigma_{b}\right) z}{\cos \theta_{0}}} \\
(\mathrm{GV} \star \mathrm{VG}) & \Gamma_{\text {rough }}^{2} \cdot\left(\mathbf{F} \star \mathbf{R}\left(\theta_{\text {spec }}\right)\right) \cdot e^{-\frac{\left(\sigma_{a}+\sigma_{b}\right) h_{v}}{\cos \theta_{0}}} \cdot e^{-\frac{j 2 k_{0}\left(\chi_{a}-\chi_{b}\right) z}{\cos \theta_{0}}} \\
(\mathrm{VG} \star \mathrm{GV}) & \Gamma_{\text {rough }}^{2} \cdot\left(\mathbf{F} \star \mathbf{R}\left(\theta_{\text {spec }}\right)\right) \cdot e^{-\frac{\left(\sigma_{a}+\sigma_{b}\right) h_{v}}{\cos \theta_{0}}} \cdot e^{\frac{j 2 k_{0}\left(\chi_{a}-\chi_{b}\right) z}{\cos \theta_{0}}} \\
(\mathrm{VG} \star \mathrm{VG}) & \Gamma_{\text {rough }}^{2} \cdot\left(\mathbf{F} \star \mathbf{R}\left(\theta_{\text {spec }}\right)\right) \cdot e^{-\frac{\left(\sigma_{a}+\sigma_{b}\right) h_{v}}{\cos \theta_{0}}} \cdot e^{\frac{-\left(\sigma_{a}-\sigma_{b}\right) z}{\cos \theta_{0}}}
\end{aligned}
$$

Accordingly, the cross correlation yields:

$$
\begin{aligned}
\left\langle\hat{r}_{e} \cdot \vec{E}_{\hat{t}_{e}}\left(\vec{R}_{e 1}\right)\right. & \left.\cdot \hat{r}_{e}^{*} \cdot \vec{E}_{\hat{t}_{e}}^{*}\left(\vec{R}_{e 2}\right)\right\rangle=A^{4} \cdot e^{j \phi_{0}} \cdot \int_{0}^{2 \pi} W_{\eta}^{2} d \eta \cdot \int_{-\infty}^{+\infty} W_{r}^{2} r_{0} e^{j \alpha_{r} r} d r \cdot \rho_{0} \cdot e^{-\frac{\left(\sigma_{a}+\sigma_{b}\right) h_{v}}{\cos \theta_{0}}} . \\
& \cdot\left[\left|\mathbf{F}_{\hat{r}_{e} \hat{t}_{e}}\right|^{2} \cdot \int_{0}^{h_{v}} e^{\left(\frac{\sigma_{a}+\sigma_{b}}{\cos \theta_{0}}+j \alpha_{z}\right) z} d z+(\mathrm{V} \star \mathrm{V})\right. \\
& +\Gamma_{\text {rough }}^{2} \cdot\left(\mathbf{F} \star \mathbf{R}\left(\theta_{\text {spec }}\right)\right) \cdot \int_{0}^{h_{v}} e^{\left(\frac{\sigma_{a}-\sigma_{b}}{\cos \theta_{0}}+j \kappa_{z}\right) z} d z+(\mathrm{GV} \star \mathrm{GV}) \\
& +\Gamma_{\text {rough }}^{2} \cdot\left(\mathbf{F} \star \mathbf{R}\left(\theta_{\text {spec }}\right)\right) \cdot \int_{0}^{h_{v}} e^{-j\left(\frac{2 k_{0}\left(x a-\chi_{b}\right)}{\cos \theta_{0}}+\kappa_{z}\right) z} d z+\quad(\mathrm{GV} \star \mathrm{VG}) \\
& +\Gamma_{\text {rough }}^{2} \cdot\left(\mathbf{F} \star \mathbf{R}\left(\theta_{\text {spec }}\right)\right) \cdot \int_{0}^{h_{v}} e^{j\left(\frac{2 k_{0}\left(\chi_{a}-\chi_{b}\right)}{\cos \theta_{0}}+\kappa_{z}\right) z} d z+\quad(\mathrm{VG} \star \mathrm{GV}) \\
& \left.+\Gamma_{\text {rough }}^{2} \cdot\left(\mathbf{F} \star \mathbf{R}\left(\theta_{\text {spec }}\right)\right) \cdot \int_{0}^{h_{v}} e^{-\left(\frac{\sigma_{a}-\sigma_{b}}{\cos \theta_{0}+j \kappa_{z}}\right) z} d z\right] \quad(\mathrm{VG} \star \mathrm{VG})
\end{aligned}
$$

Then, simplifying the specular terms and calculating the integrals, expression (4.69) is rewritten as

$$
\begin{aligned}
\left\langle\hat{r}_{e} \cdot \vec{E}_{\hat{t}_{e}}\left(\vec{R}_{e 1}\right)\right. & \left.\cdot \hat{r}_{e}^{*} \cdot \vec{E}_{\hat{t}_{e}}^{*}\left(\vec{R}_{e 2}\right)\right\rangle=K \cdot e^{j \phi_{0}} \cdot\left[\left|\mathbf{F}_{b_{\hat{r}_{e} \hat{t}_{e}}}\right|^{2} \cdot \frac{1}{\frac{\sigma_{a}+\sigma_{b}}{\cos \theta_{0}}+j \alpha_{z}} \cdot\left(e^{\left(\frac{\sigma_{a}+\sigma_{b}}{\cos \theta_{0}}+j \alpha_{z}\right) h_{v}}-1\right)+\right. \\
& +\Gamma_{\text {rough }}^{2} \cdot\left(\mathbf{F} \star \mathbf{R}\left(\theta_{\text {spec }}\right)\right) \cdot \frac{2}{\frac{2 k_{0}\left(\chi_{a}-\chi_{b}\right)}{\cos \theta_{0}}+\kappa_{z}} \cdot \sin \left[\left(\frac{2 k_{0}\left(\chi_{a}-\chi_{b}\right)}{\cos \theta_{0}}+\kappa_{z}\right) h_{v}\right]+ \\
& \left.+\Gamma_{\text {rough }}^{2} \cdot\left(\mathbf{F} \star \mathbf{R}\left(\theta_{\text {spec }}\right)\right) \cdot \frac{2}{\frac{\sigma_{a}-\sigma_{b}}{\cos \theta_{0}}+j \kappa_{z}} \cdot \sinh \left[\left(\frac{\sigma_{a}-\sigma_{b}}{\cos \theta_{0}}+j \kappa_{z}\right) h_{v}\right]\right]
\end{aligned}
$$

The normalizing factor is obtained from the computation of the cross correlation in (4.69) with no interferometric information considered, which is equivalent to make $\phi_{0}=0, \alpha_{z}=0$ and $\kappa_{z}=0$. Therefore, for each end of the baseline one obtains 


$$
\begin{aligned}
\left\langle\left|\hat{r}_{e} \cdot \vec{E}_{\hat{t}_{e}}\left(\vec{R}_{1,2}\right)\right|^{2}\right\rangle & =K \cdot\left[\left|\mathbf{F}_{\hat{r}_{e} \hat{t}_{e}}\right|^{2} \cdot \frac{1}{\frac{\sigma_{a}+\sigma_{b}}{\cos \theta_{0}}} \cdot\left(e^{\left(\frac{\sigma_{a}+\sigma_{b}}{\cos \theta_{0}}\right) h_{v}}-1\right)+\right. \\
& +\Gamma_{\text {rough }}^{2} \cdot\left(\mathbf{F} \star \mathbf{R}\left(\theta_{\text {spec }}\right)\right) \cdot \frac{2}{\frac{2 k_{0}\left(\chi_{a}-\chi_{b}\right)}{\cos \theta_{0}}} \cdot \sin \left[\left(\frac{2 k_{0}\left(\chi_{a}-\chi_{b}\right)}{\cos \theta_{0}}\right) h_{v}\right]+ \\
& \left.+\Gamma_{\text {rough }}^{2} \cdot\left(\mathbf{F} \star \mathbf{R}\left(\theta_{\text {spec }}\right)\right) \cdot \frac{2}{\frac{\sigma_{a}-\sigma_{b}}{\cos \theta_{0}}} \cdot \sinh \left[\left(\frac{\sigma_{a}-\sigma_{b}}{\cos \theta_{0}}\right) h_{v}\right]\right]
\end{aligned}
$$

Then, dividing expression (4.70) by (4.71) and redefining the ground-to-volume ratio as

$$
\mu_{\hat{r}_{e} \hat{t}_{e}}=\frac{2 \cdot \Gamma_{\text {rough }}^{2} \cdot\left(\mathbf{F} \star \mathbf{R}\left(\theta_{\text {spec }}\right)\right)}{\left|\mathbf{F}_{b_{\hat{r}_{e} \hat{t}_{e}}}\right|}
$$

the coherence function for an oriented volume over the double bounce effect, considering a single-transmit interferometer yields

$$
\gamma=e^{j \phi_{0}} \frac{\gamma_{i n t}+\mu_{\hat{r}_{e}} \hat{t}_{e} \cdot\left[\frac{1}{\frac{2 k_{0}\left(\chi_{a}-\chi_{b}\right)}{\cos \theta_{0}}+\kappa_{z}} \cdot \sin \left[\left(\frac{2 k_{0}\left(\chi_{a}-\chi_{b}\right)}{\cos \theta_{0}}+\kappa z\right) h_{v}\right]+\frac{1}{\frac{\sigma_{a}-\sigma_{b}}{\cos \theta_{0}+j \kappa_{z}}} \cdot \sinh \left[\left(\frac{\sigma_{a}-\sigma_{b}}{\cos \theta_{0}}+j \kappa z\right) h_{v}\right]\right]}{I_{0}+\mu_{\hat{r}_{e} \hat{t}_{e}} \cdot\left[\frac{1}{\frac{2 k_{0}\left(\chi_{a}-\chi_{b}\right)}{\cos \theta_{0}}} \cdot \sin \left[\left(\frac{2 k_{0}\left(\chi_{a}-\chi_{b}\right)}{\cos \theta_{0}}\right) h_{v}\right]+\frac{1}{\left.\frac{\sigma_{a}-\sigma_{b}}{\cos \theta_{0}} \cdot \sinh \left[\left(\frac{\sigma_{a}-\sigma_{b}}{\cos \theta_{0}}\right) h_{v}\right]\right]}\right.}
$$

where functions $\gamma_{\text {int }}$ and $I_{0}$ represent the cross correlation for the oriented volume considering the interferometric and a volume scattering integral, respectively, and correspond to the following expressions:

$$
\begin{aligned}
\gamma_{i n t} & =\frac{1}{\frac{\sigma_{a}+\sigma_{b}}{\cos \theta_{0}}+j \alpha_{z}} \cdot\left[e^{\left(\frac{\sigma_{a}+\sigma_{b}}{\cos \theta_{0}}+j \alpha_{z}\right) h_{v}}-1\right] \\
I_{0} & =\frac{1}{\frac{\sigma_{a}+\sigma_{b}}{\cos \theta_{0}}} \cdot\left[e^{\left(\frac{\sigma_{a}+\sigma_{b}}{\cos \theta_{0}}\right) h_{v}}-1\right]
\end{aligned}
$$

Note that the volume coherence is expressed as

$$
\gamma_{v}=\frac{\gamma_{\text {int }}}{I_{0}}
$$

If all polarizations are assumed to propagate at the same velocity then refractivity indices are equal, $\chi_{a}=\chi_{b}$. Note that this is a reasonable approximation in agricultural crops scenarios, 
due to the short vegetation depth (see discussion after equation 20 in [TMMv96]). Under this assumption the following limit

$$
\lim _{\left(\chi_{a}-\chi_{b}\right) \rightarrow 0} \gamma
$$

leads to

$$
\gamma=e^{j \phi_{0}} \cdot \frac{\gamma_{i n t}+\mu_{\hat{r}_{e} \hat{t}_{e}} \cdot\left[\frac{1}{\kappa_{z}} \cdot \sin \left(\kappa_{z} \cdot h_{v}\right)+\frac{1}{\frac{\sigma_{a}-\sigma_{b}}{\cos \theta_{0}}+j \kappa_{z}} \cdot \sinh \left[\left(\frac{\sigma_{a}-\sigma_{b}}{\cos \theta_{0}}+j \kappa_{z}\right) h_{v}\right]\right]}{I_{0}+\mu_{\hat{r}_{e} \hat{t}_{e}} \cdot\left[h_{v}+\frac{1}{\frac{\sigma_{a}-\sigma_{b}}{\cos \theta_{0}}} \cdot \sinh \left[\left(\frac{\sigma_{a}-\sigma_{b}}{\cos \theta_{0}}\right) h_{v}\right]\right]}
$$

Finally, dividing numerator and denominator of (4.77) by $I_{0}$, a more conventional form for the complex interferometric coherence is obtained

$$
\gamma=e^{j \phi_{0}} \cdot \frac{\gamma_{v}+\frac{1}{I_{0}} \cdot \mu_{\hat{r}_{e} \hat{t}_{e}} \cdot\left[\frac{1}{\kappa_{z}} \cdot \sin \left(\kappa_{z} \cdot h_{v}\right)+\frac{1}{\frac{\sigma_{a}-\sigma_{b}}{\cos \theta_{0}}+j \kappa_{z}} \cdot \sinh \left[\left(\frac{\sigma_{a}-\sigma_{b}}{\cos \theta_{0}}+j \kappa_{z}\right) h_{v}\right]\right]}{1+\frac{1}{I_{0}} \cdot \mu_{\hat{r}_{e} \hat{t}_{e}} \cdot\left[h_{v}+\frac{1}{\frac{\sigma_{a}-\sigma_{b}}{\cos \theta_{0}}} \cdot \sinh \left[\left(\frac{\sigma_{a}-\sigma_{b}}{\cos \theta_{0}}\right) h_{v}\right]\right]}
$$

Note that previous expressions describe a single-transmit mode interferometer. If a pingpong mode system is used, as in the case of a repeat-pass interferometer, the considerations stated in the RVoG case apply again, and the multiplying factor ( $h_{v}$ plus a term depending on $\sigma_{a}-\sigma_{b}$ ) modifies the $\mu_{\hat{r}_{e} \hat{t}_{e}}$ parameter at both numerator and denominator of (4.78). Hence, the coherence expression for the ping-pong mode is

$$
\gamma=e^{j \phi_{0}} \cdot \frac{\gamma_{v}+\frac{1}{I_{0}} \cdot \mu_{\hat{r}_{e} \hat{e}_{e}} \cdot\left[h_{v}+\frac{1}{\frac{\sigma_{a}-\sigma_{b}}{\cos \theta_{0}}} \cdot \sinh \left[\left(\frac{\sigma_{a}-\sigma_{b}}{\cos \theta_{0}}\right) h_{v}\right]\right]}{1+\frac{1}{I_{0}} \cdot \mu_{\hat{r}_{e} \hat{t}_{e}} \cdot\left[h_{v}+\frac{1}{\frac{\sigma_{a}-\sigma_{b}}{\cos \theta_{0}}} \cdot \sinh \left[\left(\frac{\sigma_{a}-\sigma_{b}}{\cos \theta_{0}}\right) h_{v}\right]\right]}
$$

In Fig. 4.8 the coherence loci for the OVoG model corresponding to both single-tx and alternate-tx modes, for a single typical agricultural configuration, is shown. In this plot, each solid line shows the possible positions of each different polarization channel considering different ground-to-volume ratios, but assuming the same eigenpolarization, i.e. $a a$, $b b, a b$ and $b a$. Lines are defined by considering different vegetated media, which translates

90 


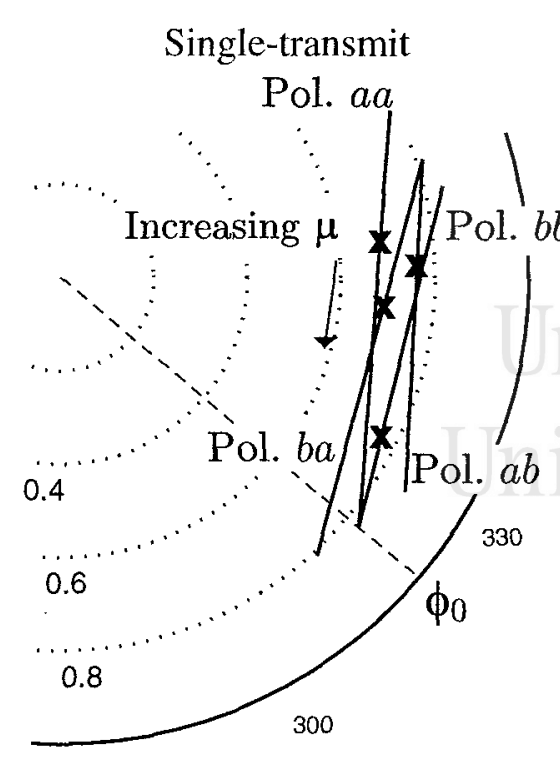

270

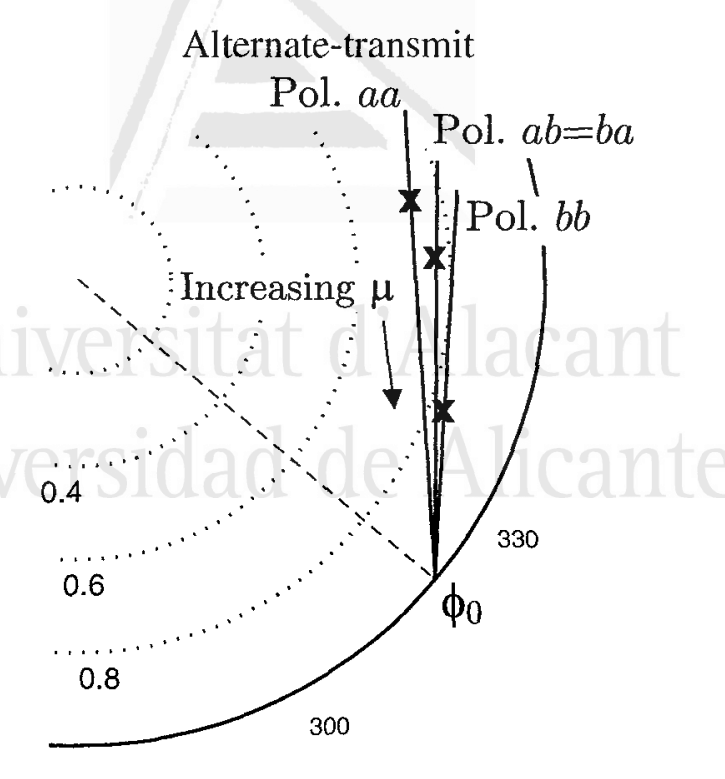

270

(a)

(b)

Figure 4.8: Loci of possible coherences of the OVoG model for single-tx (a) and alternate-tx (b) modes. Parameters: $\theta_{0}=45^{\circ}, \kappa_{z}=0.75, \phi_{0}=-40^{\circ},-40 \mathrm{~dB} \leq \mu_{\hat{r} e} \hat{t}_{e} \leq+40 \mathrm{~dB}$. Data: $\sigma_{a}=3$ $\mathrm{dB} / \mathrm{m}, \sigma_{b}=0 \mathrm{~dB} / \mathrm{m}, h_{v}=2 \mathrm{~m}$.

into varying ground-to-volume ratios. Evidently, in a real experiment we obtain only four coherence points, each of them lying on each line, as depicted with crosses on the same plot. In principle, similar comments to those for the RVoG case apply to these loci, but new interesting features appear too.

In the single-tx case (see Fig. 4.8.a), the extreme lines, which correspond to the copolar channels $a a$ and $b b$, are similar to those of the RVoG case when we study different extinctions (see Fig. 4.6.c). Again, the single-tx configuration entails a decrease in the coherence amplitude, even for an infinite ground-to-volume ratio, as a consequence of the volume decorrelation produced by the change in the propagation paths to both ends of the baseline. Phase topography $\phi_{0}$ can be identified by the phase of the copolar coherences with infinite ground-to-volume ratios.

The most interesting feature of this formulation, which is illustrated in Fig. 4.8.a, is the distribution of the complex coherence for the cross-polar channels. First, both crosspolar channels, $a b$ and $b a$, do not show the same loci (except for a null ground contribution) because of the different extinctions within the vegetation volume and the bistatic configuration. Second, the crosspolar lines are not confined in the region defined by the two copolar cases, in contrast to the alternate-tx case. Finally, and more importantly, the phase of the crosspolar coherences with an infinite ground-to-volume ratio does not correspond to the topographic phase. Mathematically, this phase shift can be identified in (4.78), because when $\sigma_{a} \neq \sigma_{b}$ the numerator includes a complex (not real) term that modifies the total phase of the coherence, 
which is not $\phi_{0}$ anymore. From the physical point of view, the phase change is produced by the different extinctions affecting the double-bounce contributions, $\left\langle\vec{E}_{\hat{t}_{1}}^{G V}\right\rangle$ and $\left\langle\vec{E}_{\hat{t}_{1}}^{V G}\right\rangle$, when propagating to end 1 of the baseline in contrast to end 2 . The different paths inside the vegetation volume, with different extinctions in the OVoG case, provoke different magnitudes of the received fields at both antennas. Consequently, in the interferometric cross products the complex numbers do not exhibit the same modulus and the resulting phase is not cancelled. This shift is proportional to the vegetation height.

\subsubsection{Effect of the bistatic angle}

In order to quantify the impact of the additional decorrelation term as a function of the bistatic angle, a number of additional simulations have been performed. Parameter values are assumed to be those from the future TanDEM-X space-borne system [KMF+ 06], with the maximum baseline of $2 \mathrm{~km}$. Figs. 4.9.a-b illustrate the effect of baseline variation on the coherence loci for incidence angles of $25^{\circ}$ and $45^{\circ}$, respectively. It is observed that $\alpha_{z}$ should be maintained below 1.5 in order to avoid low coherences, which would degrade a potential inversion application. This upper limit of $\alpha_{z}$ corresponds to baselines of $889.5 \mathrm{~m}$ and $1907.4 \mathrm{~m}$, respectively. Note that, for simplicity, we have assumed that the angle formed by the baseline and the horizontal is equal to the incidence angle. The corresponding values of $\kappa_{z}$ are 0.27 and 0.75 for each incidence angle.

Additionally, the spectral shift due to baseline decorrelation must be also considered. The frequency shift $\Delta f$ between both images is [GMP+94]:

$$
\Delta f=\frac{f B_{n}}{r_{0} \tan \left(\theta_{0}-\alpha\right)}
$$

where $f$ is the carrier frequency, $r_{0}$ is the distance between antennas and ground, $B_{n}$ is the effective baseline, $\theta_{0}$ is the mean incidence angle and $\alpha$ the local slope of the surface. In these cases, the baselines for incidences of $25^{\circ}$ and $45^{\circ}$ produce spectral shifts of $32.5 \mathrm{MHz}$ and $25.3 \mathrm{MHz}$, respectively, which are acceptable considering that the TanDEM-X system provides a $150 \mathrm{MHz}$ nominal bandwidth.

The model presented here has been used in order to retrieve estimates from several kinds of oriented volumes, such as rice and corn crops. Inversion results and a thorough discussion about the applicability of such models is provided in Chapter 5. 


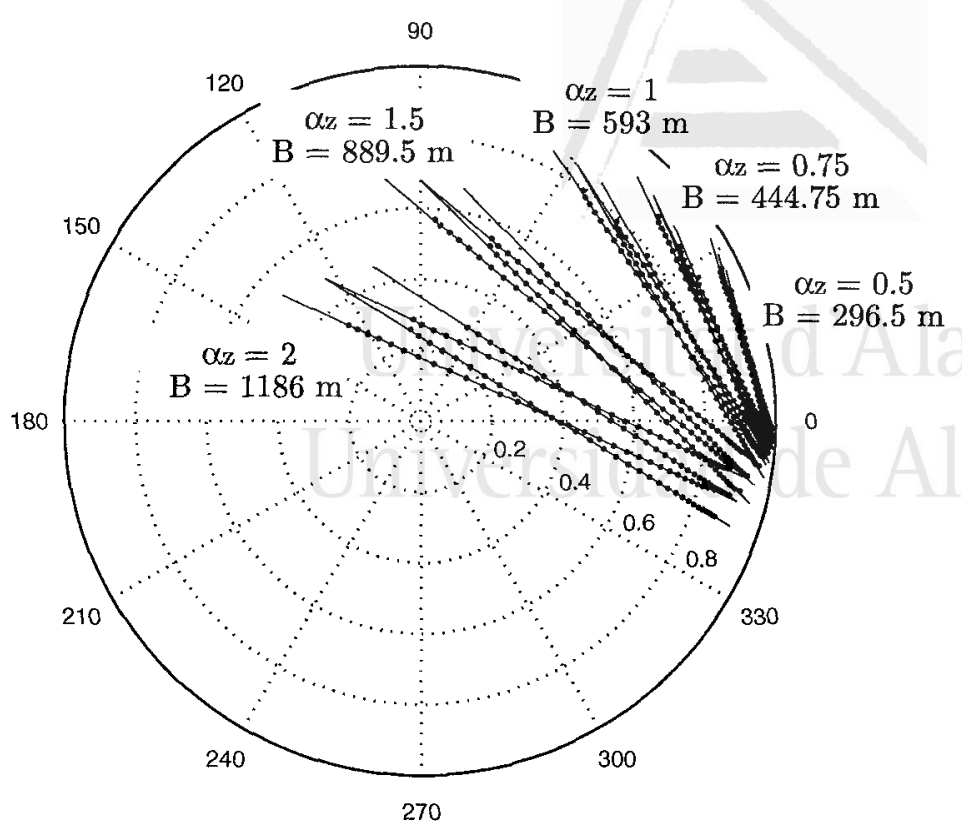

(a)

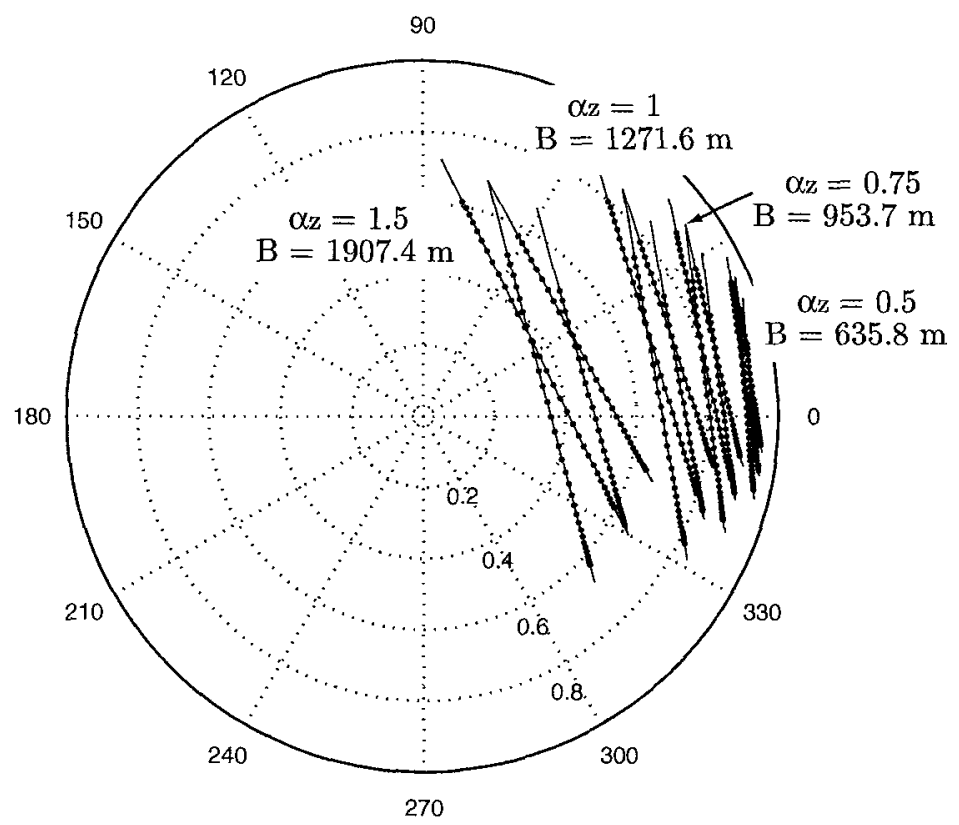

(b)

Figure 4.9: Loci of possible coherences of the OVoG model for single-tx as a function of bistatic angle: a) $\theta_{0}=25^{\circ}$; b) $\theta_{0}=45^{\circ}$. Parameters: $f=9.65 \mathrm{GHz}, \delta=\theta_{0}, H=514 \mathrm{~km}, z_{0}=-0.7 \mathrm{~m}$, $-40 \mathrm{~dB} \leq \mu_{\hat{r}_{e} \hat{t}_{e}} \leq+40 \mathrm{~dB}(-10 \mathrm{~dB}$ and $+10 \mathrm{~dB}$ values are marked with bigger dots $), \sigma_{a}=3 \mathrm{~dB} / \mathrm{m}, \sigma_{b}$ $=0.5 \mathrm{~dB} / \mathrm{m}, h_{v}=2 \mathrm{~m}$. 


\section{Retrieval of Biophysical Parameters of} Agricultural Crops by Using PolInSAR and Simple Models

As already outlined in Chapter 2, there are two main groups of algorithms for the retrieval of biophysical parameters from synthetic aperture radar (SAR) imagery. The first group of algorithms makes exclusive use of the power images, with estimates of biomass and other biophysical parameters obtained from the backscattering coefficient $\left(\sigma_{0}\right)$. A well known limitation of this technique is that above a certain threshold of forest biomass, the backscattering coefficient saturates. The inversion results obtained at low frequencies (i.e. $\mathrm{L}$ or $\mathrm{P}$ band) are usually more accurate, even if the saturation problem is still present [mh95]. Moreover, the complex nature of the interaction of the electromagnetic waves with the vegetation cover makes the development of a robust and precise inversion scheme very challenging. When applied to agricultural fields, the inversion of the plant height is usually based on a linear model that mimics the time series of $\sigma_{0}$ data [LRW'97].

The second group of algorithms makes use of both the amplitude and phase of the SAR images, which entails an enlargement of the dimensionality of the observables space. As a matter of fact, the phase information content has been extensively exploited in a number of SAR interferometry applications [WW97, LS996, Sa97, TMMY9, TS00, PCOH]. In all of them a direct model establishing the relationship between the parameters to be estimated (i.e. vegetation height, underlying topography, etc.) and the observables (i.e. interferometric coherence, backscattering coefficient, polarization dependence) is used. In the last step, an inversion procedure to obtain the unknown parameters from the image data is designed.

Within this second group of algorithms, there are a few that combine radar polarimetry and SAR interferometry, that is to say, polarimetric SAR interferometry (PolInSAR). PolInSAR retrieval algorithms are, in principle, more effective in separating the different scattering centers present in the vegetation cover. An outstanding example of a vegetation cover model 
specifically developed for PolInSAR is given in [TMMv96, TS00]. In this model, the interferometric cross-products in the different polarization channels were linked to the physical structure of various scenes: a random volume without ground, a random volume over the ground, and an oriented volume without ground.

The model of a random volume over ground was proposed to address the issue of forest height retrieval and biomass estimation. Based on this model, a formulation establishing the relationship between the PolInSAR observables and the biophysical parameters has been developed [PCO), CP03]. An interesting feature of this inversion scheme is that it has associated a physics-based and simple interpretation. The positions of the coherence values corresponding to the model lie along a straight line on the complex plane. This line intersects the unit circle at the ground topographic height. Moreover, the thickness of the vegetation cover and the extinction coefficient are estimated finding the intersection point of the straight line and the curve of the model's volume coherence function [CP03]. The main application of this model is the retrieval of forest height. However, this model is not appropriate for many agricultural crops with a well-defined preferred orientation, which are also known as oriented volumes.

When defining an inversion scheme for agricultural crops, it is important to keep in mind the following considerations:

- The propagation of the electromagnetic waves through an oriented volume is anisotropic because the extinction coefficients are highly polarization dependent. This feature distinguishes an oriented from a random volume, and it is taken into account in the electromagnetic modelling by means of the so-called eigenpolarizations [TKS85, TC99]. They represent two orthogonal polatization states that can be propagated through the volume, and correspond to the maximum and minimum values of the extinction coefficient.

- The ground-stem dihedral response is usually dominant and, sometimes, it can mask any other backscatter contributions. Actually, one can find many different situations, mainly depending on the incidence angle, the frequency band, the type and condition of the soil, and the kind of vegetation. For example, in rice crops applications there is a wide range of frequencies for which the double-bounce contribution dominates the backscattered signal, due to the short vegetation volume and the flooded soil. On the other hand, in forested areas, the ground-trunk interaction dominates the backscattering only for lower frequencies, i.e. P- and L-band.

- Compared to forest height retrieval, crop monitoring requires more precise estimates due to the short vegetation volume and the necessity of a high accuracy in real applications. Therefore larger baselines than those for forest height retrieval must be used.

- The fast growth cycle of the crops introduces a strong temporal decorrelation. As a result, only single-pass or short temporal baseline systems are suitable. 
- Crops planted in a grid show a backscatter intensity with a strong amplitude modulation as a function of the azimuth aspect angle and the geometry of the plantation grid. In addition, backscattering variations have been also observed depending on the sowing process, i.e. mechanical or manual [Ros98].

First and second items are related to the electromagnetic modelling of agricultural crops, whereas the third and the fourth one have to do with the design of the interferometer. The present work is focused on the three first issues. The study of the temporal decorrelation and the plantation grid effects has not been addressed here.

It must be noted that the first retrieval results about agricultural crops, by means of PolInSAR, were published in [PRS ${ }^{+98}$ ], but no ground truth was available at that moment and the inversion technique was based only on phase differences.

This chapter is organized as follows. First, the formulation of the direct model proposed in [TSO0], and employed in [CP03], is revisited. The objective is to assess its applicability to agricultural crops. Note that the presence of the ground, together with an oriented volume, was not explicitly studied in those references (see also [CPBO0]). Second, possible inversion strategies for the oriented volume over ground surface are described. Next, the proposed model and associated inversion scheme have been tested with wide-band fully-polarimetric data collected in the anechoic chamber of the European Microwave Signature Laboratory (EMSL), at JRC-Ispra, Italy. The vegetation samples used in the experiments consisted of clusters of rice and maize at a mature growth stage. Inversion results obtained with different combinations of polarizations channels have been analyzed. In addition to the indoor measurements, the potential use of the proposed inversion scheme with air- and space-borne imagery is also addressed.

\subsection{RVoG and OVoG Models}

In this section the basic concepts of the RVoG and OVoG models, developed in Chapter 4 , are summarized.

The starting point of this formulation is the generalization of conventional SAR interferometry to the vector case, in order to merge the polarimetric information into this technique [CP98]. With this extension, the main observable in PolInSAR is the $6 \times 6$ coherency matrix of a pixel, defined as:

$$
\left\langle\mathbf{k} \cdot \mathbf{k}^{* T}\right\rangle=\left[\begin{array}{cc}
\mathbf{T}_{11} & \Omega_{12} \\
\Omega_{12}^{* T} & \mathbf{T}_{22}
\end{array}\right],
$$

where $\mathbf{k}$ is the target vector formed by the Pauli basis arrangement of all polarization channels at the two images:

$$
\mathbf{k}=\frac{1}{\sqrt{2}}\left[S_{h h}^{1}+S_{v v}^{1}, S_{h h}^{1}-S_{v v}^{1}, 2 S_{h v}^{1}, S_{h h}^{2}+S_{v v}^{2}, S_{h h}^{2}-S_{v v}^{2}, 2 S_{h v}^{2}\right]^{T} .
$$


Here the superscripts 1 and 2 identify the measurements at the two ends of the baseline, and the $S_{p q}$ entries denote the scattering matrix coefficients with $p$-polarized reception and $q$-polarized transmission. Note that the $3 \times 3$ coherency matrices $\mathbf{T}_{i i}$ carry polarimetric information, whereas the $\Omega_{12}$ matrix contains both polarimetric and interferometric information.

From equation (5.1), the complex interferometric coherence can be computed as [CP98]

$$
\gamma=\frac{\mathbf{w}^{* T} \boldsymbol{\Omega}_{12} \mathbf{w}}{\sqrt{\left(\mathbf{w}^{* T} \mathbf{T}_{11} \mathbf{w}\right) \cdot\left(\mathbf{w}^{* T} \mathbf{T}_{22} \mathbf{w}\right)}}
$$

where $\mathbf{w}$ are unitary projection complex vectors employed to select one polarization combination from the whole polarimetric space. Assuming, as usual [CP98], that $\mathbf{T}_{11}=\mathbf{T}_{22}$, equation (5.3) is expressed as

$$
\gamma=\frac{\mathbf{w}^{* T} \Omega_{12} \mathbf{w}}{\mathbf{w}^{* T} \mathbf{T}_{11} \mathbf{w}}
$$

In this way, the coherence obtained in (5.4) is a complex scalar magnitude. From here on, this measurable will be treated as the target function to be reproduced with a direct model that relates the PolInSAR observables to physical parameters of the scattering process.

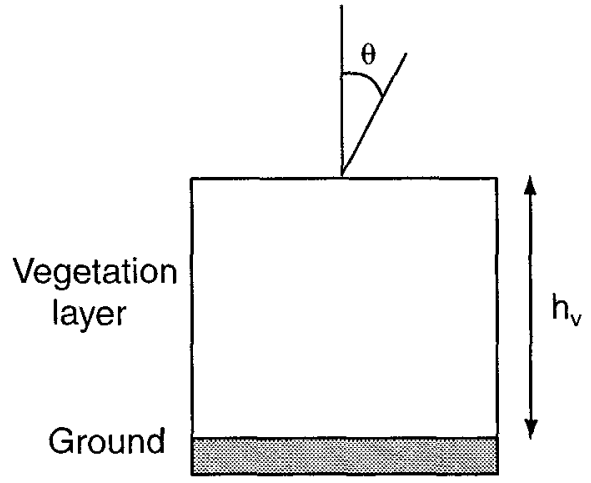

a)

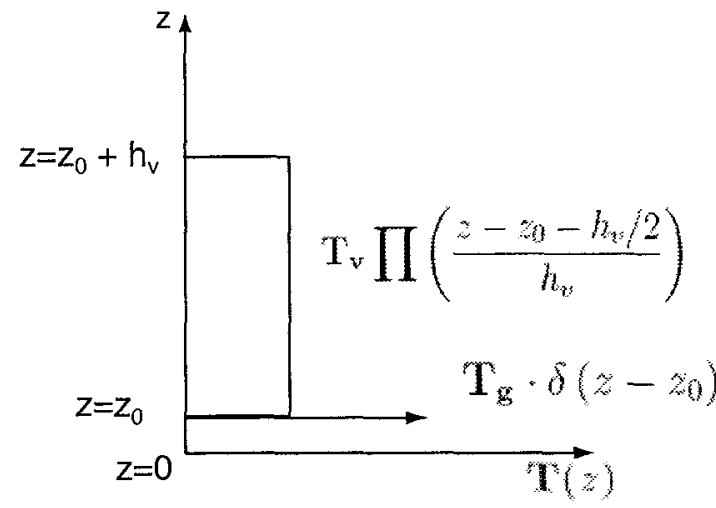

b)

Figure 5.1: Two-layer vegetation model. (a) Geometry of a vegetation volume over the ground. (b) Coherency functions of both layers.

As explained previously, the vegetation cover can be modeled as a volume over a ground plane, as depicted in Fig. 5.1 (a). This two-layer vegetation model has been used in [TMMv96, TSO0] to derive an analytical expression of the complex interferometric coherence. From this point, the derivation of the $\gamma$ function in the case of an oriented volume considering a differential extinction coefficient is as follows (see also Chapter 4 ). The transmit and receive extinction coefficients are denoted as $\sigma_{T}(\mathbf{w})$ and $\sigma_{R}(\mathbf{w})$, respectively. The matrices in (5.4) 
can be expressed as a function of the physical parameters of the scene as follows [TC99]:

$$
\begin{aligned}
& \mathbf{T}_{11}=e^{-\frac{\sigma_{T}(\mathbf{w}) h_{v}}{\cos \theta_{0}}} e^{-\frac{\sigma_{R}(\mathbf{w}) h_{v}}{\cos \theta_{0}}} \int_{z} e^{\frac{\sigma_{T}(\mathbf{w})+\sigma_{R}(\mathbf{w})}{\cos \theta_{0}} z} \mathbf{T}(z) d z \\
& \boldsymbol{\Omega}_{12}=e^{j \phi_{0}} e^{-\frac{\sigma_{T}(\mathbf{w}) h_{v}}{\cos \theta_{0}}} e^{-\frac{\sigma_{R}(\mathbf{w}) h_{v}}{\cos \theta_{0}}} \int_{z} e^{\left(\frac{\sigma_{T}(\mathbf{w})+\sigma_{R}(\mathbf{w})}{\cos \theta_{0}}+j k_{z}\right) z} \mathbf{T}(z) d z
\end{aligned}
$$

where $z$ denotes the vertical coordinate, $h_{v}$ is the vegetation height (i.e. the depth of the layer), $\theta_{0}$ is the mean incidence angle, $k_{z}$ is the mean vertical wavenumber and $\mathbf{T}(z)$ is the target coherency matrix as a function of height. Expressions in (5.5) and (5.6) are formally correct only for a random volume because in that case the polarization $w$ remains unchanged as the wave propagates through the volume. In the case of an oriented volume the polarization of the probing wave changes with $z$, i.e. $\mathbf{w}=\mathbf{w}(\mathbf{z})$. The only polarizations which do not suffer from this dependence are the eigenpolarizations [TC99], which are two orthogonal polarizations that correspond to the maximum and minimum values of the extinction coefficient (see Chapter 4). Accordingly, in the following formulation a constant effective polarization $w$ will be assumed for simplicity. Note that, as it was explained in Chapter 4 , this assumption is useful in order to develop a modified expression of the interferometric coherence as well as a subsequent retrieval procedure in case of an oriented volume, as will be shown later on in the text.

Since both extinction coefficients always appear summed, one can define an equivalent extinction coefficient in the following way: $2 \sigma_{\mathbf{w}}=\sigma_{T}(\mathbf{w})+\sigma_{R}(\mathbf{w})$. Note that the dependence on polarization is maintained in the formulation via the subscript $w$.

According to the aforementioned two-layer model, the corresponding target coherency matrix becomes:

$$
\mathbf{T}(z)=\mathbf{T}_{\mathbf{g}} \cdot \delta\left(z-z_{0}\right)+\mathbf{T}_{\mathbf{v}} \prod\left(\frac{z-z_{0}-h_{v} / 2}{h_{v}}\right)
$$

where $\delta()$ is the Dirac's delta function, and $\prod()$ denotes a rectangular pulse function. The ground height (or topography) is defined by $z_{0}$, as shown in Figure 5.1(b).

The coherency matrices $\mathbf{T}_{\mathrm{g}}$ and $\mathbf{T}_{\mathbf{v}}$ are associated with the contributions of the ground or ground-trunk interaction, and the vegetation volume, respectively. The ground plane is a reflection symmetric target [CP96, CP97], and its coherency matrix reduces to the form of equation (5.8). The oriented morphology of the agricultural vegetation can also be regarded as reflection symmetric, and its coherency matrix takes the form shown in equation (5.9).

$$
\begin{aligned}
& \mathbf{T}_{\mathbf{g}}=m_{g} \cdot\left[\begin{array}{ccc}
1 & t_{g 12} & 0 \\
t_{g 12}^{*} & t_{g 22} & 0 \\
0 & 0 & t_{g 33}
\end{array}\right] \\
& \mathbf{T}_{\mathbf{v}}=m_{v} \cdot\left[\begin{array}{ccc}
1 & t_{v 12} & 0 \\
t_{v 12}^{*} & t_{v 22} & 0 \\
0 & 0 & t_{v 33}
\end{array}\right]
\end{aligned}
$$


Without loss of generality, it can be assumed in the integrals that the ground plane is at $z_{0}=0$. Then, equations (5.5) and (5.6) can be rewritten as:

$$
\begin{aligned}
& \mathbf{T}_{11}=e^{\frac{-2 \sigma_{\mathbf{w}} h_{v}}{\cos \theta_{0}}} \cdot\left[\mathbf{T}_{\mathbf{g}}+\mathbf{T}_{\mathbf{v}} \int_{0}^{h_{v}} e^{\frac{2 \sigma_{\mathbf{W}}}{\cos \theta_{0}} z} d z\right]=e^{\frac{-2 \sigma_{\mathbf{w}} h_{v}}{\cos \theta_{0}}} \cdot\left[\mathbf{T}_{\mathbf{g}}+\mathbf{I}_{1}^{v}\right] \\
& \boldsymbol{\Omega}_{12}=e^{j \phi_{0}} e^{-\frac{2 \sigma_{\mathbf{W}} h_{v}}{\cos \theta_{0}}} \cdot\left[\mathbf{T}_{\mathbf{g}}+\mathbf{T}_{\mathbf{v}} \int_{0}^{h_{v}} e^{\left(\frac{2 \sigma_{\mathbf{W}}}{\cos \theta_{0}}+j k_{z}\right) z} d z\right]=e^{j \phi_{0}} e^{-\frac{2 \sigma h_{\mathbf{W}} h_{v}}{\cos \theta_{0}}} \cdot\left[\mathbf{T}_{\mathbf{g}}+\mathbf{I}_{2}^{v}\right]
\end{aligned}
$$

It is important to remind that the integrals $\mathbf{I}_{1}^{v}$ and $\mathbf{I}_{2}^{v}$ can be calculated by assuming that the extinction coefficients are constant along the volume, regardless their dependence on the slant-range dimension. Then, evaluating analytically the integrals yields:

$$
\begin{aligned}
& \mathbf{I}_{1}^{v}=\frac{\cos \theta_{0}}{2 \sigma_{\mathbf{w}}}\left(e^{\frac{2 \sigma_{\mathbf{w}} h_{v}}{\cos \theta_{0}}}-1\right) \mathbf{T}_{\mathbf{v}} \\
& \mathbf{I}_{2}^{v}=\frac{1}{\frac{2 \sigma_{\mathbf{W}}}{\cos \theta_{0}}+j k_{z}}\left(e^{\frac{2 \sigma_{\mathbf{W}} h_{v}}{\cos \theta_{0}}} e^{j k_{z} h_{v}}-1\right) \mathbf{T}_{\mathbf{v}}
\end{aligned}
$$

The resulting complex interferometric coherence is:

$$
\gamma=e^{j \phi_{0}} \cdot \frac{\mathbf{w}^{* T}\left[e^{\frac{-2 \sigma_{\mathbf{w}} h_{v}}{\cos \theta_{0}}} \mathbf{T}_{\mathbf{g}}+e^{\frac{-2 \sigma_{\mathbf{w}} h_{y}}{\cos \theta_{0}}} \mathbf{I}_{2}^{v}\right] \mathbf{w}}{\mathbf{w}^{* T}\left[e^{\frac{-2 \sigma_{\mathbf{w}} h_{v}}{\cos \theta_{0}}} \mathbf{T}_{\mathbf{g}}+e^{\frac{-2 \sigma_{\mathbf{w}} h_{y}}{\cos \theta_{0}}} \mathbf{I}_{1}^{v}\right] \mathbf{w}} .
$$

As indicated in [CP03], one can transform equation (5.14) into:

$$
\gamma=e^{j \phi_{0}} \cdot \frac{\mu\left(\sigma_{\mathbf{w}}, \mathbf{w}\right)+\gamma_{v}\left(\sigma_{\mathbf{w}}, \mathbf{w}\right)}{1+\mu\left(\sigma_{\mathbf{w}}, \mathbf{w}\right)}
$$

where the volume coherence $\gamma_{v}$ and the ground-to-volume ratio $\mu$ have been redefined as:

$$
\begin{aligned}
\gamma_{v}\left(\sigma_{\mathbf{w}}, \mathbf{w}\right) & =\frac{\mathbf{w}^{* T} e^{\frac{-2 \sigma_{\mathbf{w}} h_{y}}{\cos \theta_{0}}} \mathbf{I}_{2}^{v} \mathbf{w}}{\mathbf{w}^{* T} e^{\frac{-2 \sigma_{\mathbf{w}} h_{v}}{\cos \theta_{0}}} \mathbf{I}_{1}^{v} \mathbf{w}} \\
\mu\left(\sigma_{\mathbf{w}}, \mathbf{w}\right) & =\frac{\mathbf{w}^{* T} e^{\frac{-2 \sigma_{\mathbf{w}} h_{v}}{\cos \theta_{0}}} \mathbf{T}_{\mathbf{g}} \mathbf{w}}{\mathbf{w}^{* T} e^{\frac{-2 \sigma_{\mathbf{w}} h_{v}}{\cos \theta_{0}}} \mathbf{I}_{1}^{v} \mathbf{w}} .
\end{aligned}
$$

Note that these two functions depend on polarization in two ways. First, the selected polarization combination (projection vector $w$ ) combines only the elements chosen from the coherency matrices $\mathbf{T}_{\mathrm{g}}$ and $\mathbf{T}_{\mathbf{v}}$. Second, a different extinction coefficient $\left(\sigma_{\mathbf{w}}\right)$ is associated with the selected polarization $w$. However, a careful analysis should be performed about the dependence of both functions upon polarization.

When a particular polarization is selected, the numerator and denominator of the volume coherence $\gamma_{v}$ share the same exponential term, $\exp \left[-2 \sigma_{\mathbf{w}} h_{v} / \cos \theta_{0}\right]$, and the same elements 
of the coherency matrix $\mathbf{T}_{\mathrm{v}}$ resulting from the integrals (5.12-5.13). Consequently, the division can be simplified, and the dependence of the volume coherence reduces to the influence of polarization on the extinction coefficient $\sigma_{\mathrm{w}}$. Hence, the volume coherence is expressed simply as:

$$
\gamma_{v}\left(\sigma_{\mathbf{w}}\right)=\frac{2 \sigma_{\mathbf{w}}}{\cos \theta_{0}\left(e^{\frac{22 h_{w}}{\cos \theta_{0}}}-1\right)} \cdot \frac{e^{\left(\frac{2 \sigma_{w}}{\cos \theta_{0}}+j k_{z}\right) h_{v}}-1}{\frac{2 \sigma_{\mathbf{w}}}{\cos \theta_{0}}+j k_{z}}
$$

On the other hand, the ground-to-volume ratio presents different coherency matrices in the numerator (ground) and the denominator (volume), so the previous simplification is not possible. Consequently, the complex interferometric coherence for the model of an oriented volume over the ground can be finally expressed as:

$$
\begin{aligned}
\gamma=e^{j \phi_{0}} \cdot \frac{\mu\left(\sigma_{\mathbf{w}}, \mathbf{w}\right)+\gamma_{v}\left(\sigma_{\mathbf{w}}\right)}{1+\mu\left(\sigma_{\mathbf{w}}, \mathbf{w}\right)}=e^{j \phi_{0}} \cdot\left[\gamma_{v}\left(\sigma_{\mathbf{w}}\right)+\frac{\mu\left(\sigma_{\mathbf{w}}, \mathbf{w}\right)}{1+\mu\left(\sigma_{\mathbf{w}}, \mathbf{w}\right)}\left(1-\gamma_{v}\left(\sigma_{\mathbf{w}}\right)\right)\right] \\
=e^{j \phi_{0}} \cdot\left[\gamma_{v}\left(\sigma_{\mathbf{w}}\right)+L\left(\sigma_{\mathbf{w}}, \mathbf{w}\right)\left(1-\gamma_{v}\left(\sigma_{\mathbf{w}}\right)\right)\right]
\end{aligned}
$$

with $0 \leqslant L\left(\sigma_{\mathbf{w}}, \mathbf{w}\right) \leqslant 1$.

It is important to remark that, in contrast with the random volume case [PCOI], the expression in (5.19) does not result in a straight line on the complex plane because the volume coherence $\gamma_{v}$ is polarization dependent. Consequently, the original inversion procedure based on the straight line model in [PCOI, $\mathrm{CPO} 3]$ could not be applied directly to oriented volumes.

\subsection{Inversion Strategies}

\subsubsection{Analysis of the Coherence Loci for an Oriented Volume over Ground}

This section is devoted to analyze the new geometrical interpretation of the complex coherence model derived for an oriented volume over the ground. The following analysis is based on physical parameters typical of agricultural fields.

In order to identify the position of the coherence values inside the unit circle (see expression (5.19)), the following scenario is assumed. A thickness of the vegetation layer $h_{v}=2 \mathrm{~m}$ (i.e. a typical value for a mature corn field), and a ground topographic phase $\phi_{0}=20^{\circ}$. The remote sensing platform is assumed to be the DLR's E-SAR airborne system [SRU ${ }^{+} 99^{-}$ working at L-band with a $50 \mathrm{~m}$ baseline and a $45^{\circ}$ incidence angle, which corresponds to a vertical wavenumber $k_{z}=0.5$. It is also assumed that the extinction coefficients $\sigma_{\mathrm{w}}$ will range from 0 to $3 \mathrm{~dB} / \mathrm{m}$. Note that extinction values larger than $2.75 \mathrm{~dB} / \mathrm{m}$ are not reported in the literature for this kind of agricultural field [UTS87]. Finally, in order to show the feasible region of the coherence, the whole range of the ground-to-volume ratios $\mu$ (from 0 to $\infty$ ) is sampled and plotted in the complex plane. The resulting loci of coherence values is shown in Figure 5.2. 


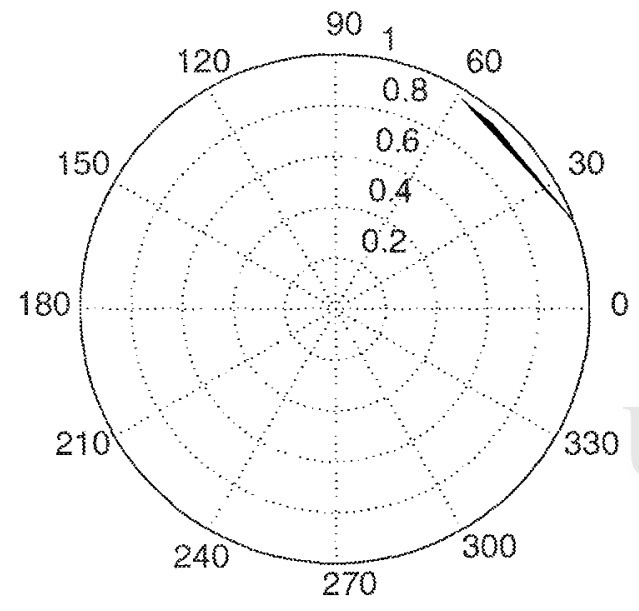

(a)

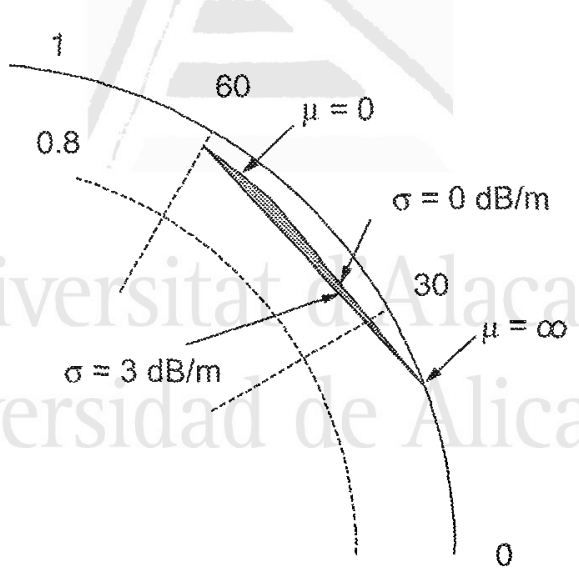

(b)

Figure 5.2: Feasible region of the coherence in the complex plane. Parameters: $h_{v}=2 \mathrm{~m}, \phi_{0}=20^{\circ}$, $k_{z}=0.5,0<\sigma<3 \mathrm{~dB} / \mathrm{m}$. (a) Complete unit circle. (b) Zoom of the feasible region, with indication of the borders

It can be observed that the shape of the region is basically a narrow triangle, and not anymore a straight line. The width of the feasible region depends both on the target and on the interferometric setup. First, the separation is directly proportional to the differential extinction coefficient $\sigma_{d i f f}$, defined as the difference between the two extinction coefficients at the eigenpolarizations: $\sigma_{\text {diff }}=\sigma_{2}-\sigma_{1}$. Second, the separation is also controlled by the product $k_{z} \cdot h_{v}$, which in turn depends on the working frequency, the baseline and the depth of the vegetation layer. If the differential extinction and the $k_{z} \cdot h_{v}$ product are maintained below a certain threshold, the region occupied by the three lines is so narrow that it can be treated as a single line, as in the case of the RVoG model. This feature has been used in this thesis to derive an OVoG inversion scheme based on the original one for the RVoG model [ $\mathrm{CPO} 3$ ].

For example, a non-realistic crop height of $h_{v}=5 \mathrm{~m}$ with a vertical wavenumber of $k_{z}=0.5$ would result in a wider triangle in the unit circle, as shown in Figure 5.3.

The same broadening of the feasible region would be found if a vegetation scene with a height of $2 \mathrm{~m}$ is observed by an interferometer with a vertical wavenumber $k_{z}=1.25$. Consequently, the triangle is expected to be narrow enough if the $k_{z} \cdot h_{v}$ product is limited to a reasonable extent (it will be discussed more deeply in Section 5.3).

In order to show the difference in the feasible region for the RVoG and the OVoG models, the loci of the complex coherences in the complex plane is represented in Fig. 5.4 for a typical configuration in two cases: a random volume over ground with an extinction of $1 \mathrm{~dB} / \mathrm{m}$, and an oriented volume over ground with extreme extinctions of 0 and $3 \mathrm{~dB} / \mathrm{m}$, respectively. In the case of a random volume, all coherences, corresponding to all possible polarizations, lie along a single straight line on the unit circle. Instead, when an oriented volume is observed, the coherences can occupy positions along three different lines, one for each possible combi- 


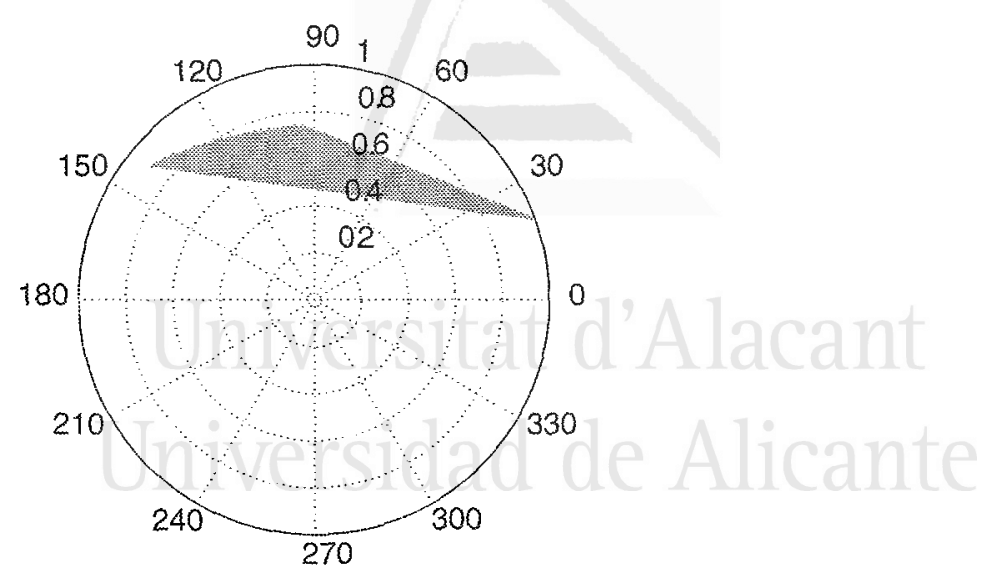

Figure 5.3: Feasible region of the coherence in the complex plane, in the case of tall vegetation. Parameters: $h_{v}=5 \mathrm{~m}, \phi_{0}=20^{\circ}, k_{z}=0.5,0<\sigma<3 \mathrm{~dB} / \mathrm{m}$.

nation of eigenpolarizations in transmission and reception (in the figure they are denoted as polarizations 1 and 2). The exact position along the line is defined by the ground-to-volume ratio $\mu$, departing from the $\exp \left(j \phi_{0}\right)$ point when $\mu \rightarrow \infty$.

By definition, the maximum and minimum extinction coefficients correspond to the eigenpolarizations as it was already explained in Section 4.3.2. Any other polarization is associated with an intermediate extinction. As it can be observed in Fig. 5.2.b, the loci of the coherences corresponding to the eigenpolarizations are the lines which define the borders of the feasible region.

\subsubsection{Comparison With Experimental Data}

In Figure 5.5 the experimental coherences of a corn sample (see Section 5.3 .1 for details about the sample) and for a given combination of frequency and baseline have been plotted onto the complex plane in order to study the correspondence of the measured data with the model. The required multi-looking is performed by averaging data acquired at different azimuth angles (by rotating the platform) and with adjacent frequency bands. For example, for the maize target we use 72 azimuth angles and 9 bands, so a total of 648 independent samples are averaged.

Figure 5.5a shows the position of the coherences on the complex plane for a particular combination of frequency $(3 \mathrm{GHz})$ and baseline $\left(0.5\right.$ degrees, $\left.k_{z}=1.56\right)$. In this case, the product $k_{z} \cdot h_{v}$ is 2.81 . We present the coherences in linear basis (VV, HH and HV, which correspond to the eigenpolarizations for a vertically oriented volume), Pauli basis and the optimized ones [CPO8]. Then, the true topographic phase $\phi_{0}$, which is known in the experiment, is used in Fig. $5.5 \mathrm{~b}$ to obtain the extreme lines that should enclose all the linear coherences ( $\mathrm{HH}, \mathrm{VV}$ and $\mathrm{HV}$ ), according to the OVoG direct model. The lowest extinction has been chosen as $0 \mathrm{~dB} / \mathrm{m}$ for simplicity. 


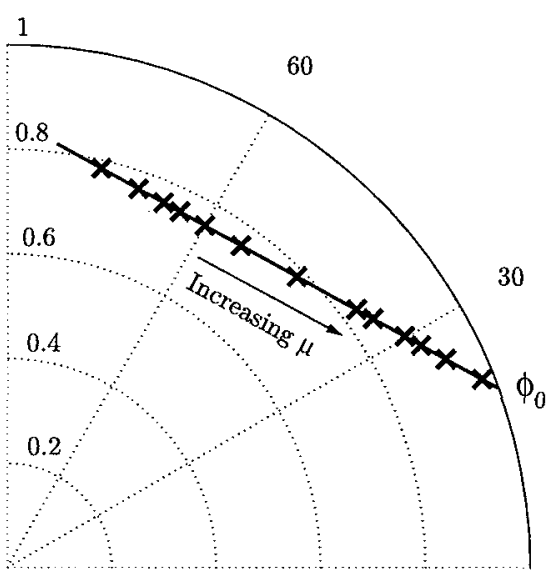

(a)

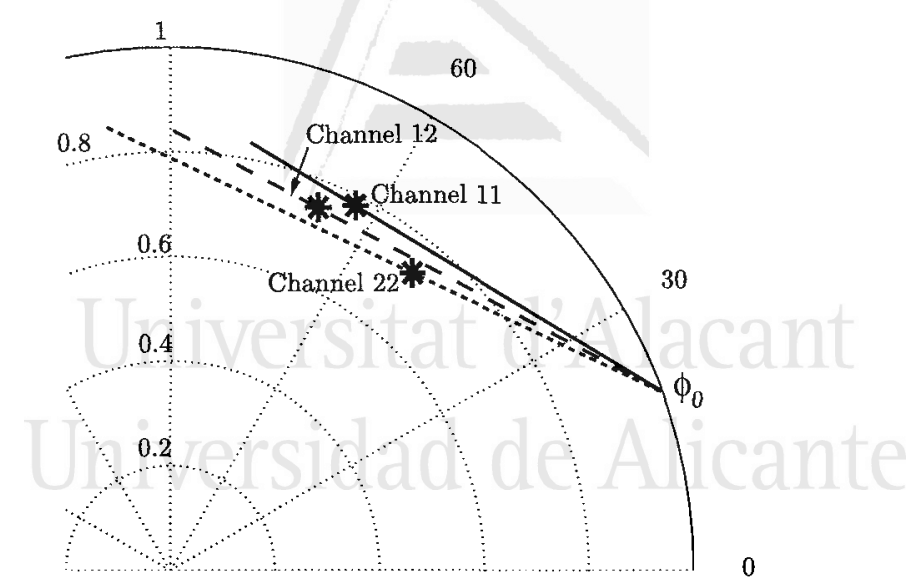

(b)

Figure 5.4: Feasible region of the coherence in the complex plane. Parameters: $h_{v}=2 \mathrm{~m}, \phi_{0}=20^{\circ}$, $k_{z}=1.04$. (a) RVoG with $\sigma=1 \mathrm{~dB} / \mathrm{m}$. (b) OVoG with $\sigma_{1}=0 \mathrm{~dB} / \mathrm{m}$ and $\sigma_{2}=3 \mathrm{~dB} / \mathrm{m}$.

Due to the vertical orientation of the plants, it is clear that vertical polarization exhibits the greatest extinction, so the line corresponding to VV is the closest to the origin. Accordingly, the $\mathrm{HH}$ coherence line would be the farthest one from the origin because horizontal polarization suffers from the lowest extinction. Note that the relative position of these extreme lines does not imply that the actual HH coherence is higher than the actual VV coherence, because these coherences are just two points (one for each channel) and the corresponding ground-tovolume at each channel is the parameter that drives the actual position along the mentioned lines. In other words, there are many points in the inner line with higher coherence than many points in the outer one.

However, in opposition to the argument of the extreme lines for the copolar channels, one can observe in Fig. 5.5b that the line crossing the HV coherence, not the $\mathrm{HH}$ one, is the farthest from the origin. We have also observed this behavior at other frequencies and in the data acquired for the rice sample.

In second place, since we know that the vegetation height is $1.80 \mathrm{~m}$, we can also overlay the region of lines corresponding to this height. To do that, we assume extinctions ranging from 0 to $5 \mathrm{~dB} / \mathrm{m}$, which are typical values for this crop [UTS87] assuming a similar development stage and analogous environmental conditions. When we do that (see Fig. 5.5c), the region defined by the model does not match the experimental data at all. Only if we reduce the vegetation depth down to $1.50 \mathrm{~m}$ and we extend the maximum extinction to $9 \mathrm{~dB} / \mathrm{m}$ (see Fig. $5.5 \mathrm{~d}$ ), the modelled and the experimental regions overlap. Recent investigations with the same data set [Clon?] have shown that the volume scattering shows a maximum response from the center of the vegetation layer and not from the top, whereas these models assume the maximum scattering always arises from the top layer, with an exponential reduction of scattering due to extinction inside the medium. Consequently, the lower position of the backscattering peak may explain partially why we have to reduce the effective height to get the fit between observations and model predictions. 
Additionally, it is also very clear that a change in several $\mathrm{dB} / \mathrm{m}$ in extinction only produces a small displacement in the coherence position. The low sensitivity of the model to this important parameter can be understood from the mathematical expression of the coherence in (5.19-5.17). Extinction is almost always multiplied by $h_{v}$ in this formulation, so the derivative of coherence with respect to extinction is approximately proportional to $h_{v}$. Since we are dealing with short vegetation scenes (up to $2 \mathrm{~m}$ ), the derivative is small and, as a result, the sensitivity to extinction is poor. This will complicate the robustness of the model inversion, as we will show in the next section.

It is also interesting to observe the region occupied by all the possible coherences derived from the data. We have computed all possible $\mathbf{w}$ vectors and they have been used to find all possible coherences from the data. The length and width of the resulting region, which is shown in Fig. 5.5.e, provide an idea of the conditioning of the inversion problem. The narrower and longer, the easier would be the solution. This triangular region can be named visible region, analogously to the visible line length defined in [CP03]. A geometrical solution of the problem for $\phi_{0}$ and $h_{v}$ is proposed in Section 5.2.2 based on the previous observations.

Following with the analysis of the matching between the model and experimental data, it is observed in Figure 5.6 the visible region corresponding to the same corn sample at $6 \mathrm{GHz}$ and a $0.25^{\circ}$ baseline, and for a rice sample (see description of the sample in Section 5.3.1) at $8 \mathrm{GHz}$ and a $0.5^{\circ}$ baseline. Note that the same value as in Figure 5.5 is maintained for the case of maize.

In the maize sample, it is possible to match the visible region with the theoretical model by choosing $h_{v}=1.7 \mathrm{~m}$ and an extinction of $3 \mathrm{~dB} / \mathrm{m}$. Repeating the same reasoning for the rice sample, an extinction of $12 \mathrm{~dB} / \mathrm{m}$ and a height of $0.62 \mathrm{~m}$ are required in order to accommodate the rice complex coherences inside the model predictions. Nevertheless, it must be noted that in the rice case all coherences are concentrated on a small cluster close to the unit circumference, so the sensitivity of the model to this parameter is quite limited.

The discrepancies between the model predictions and the experimental data can be explained by several characteristics of the model which make it specially simple. First of all, the vegetation layer is assumed to be homogeneous, and it is not true. For instance, the maize plants do not bear leaves in their lower part (about $40 \mathrm{~cm}$ from the ground). In the case of rice, the stems depart from a point of the ground surface but they separate each other as one moves towards the upper part of the plants. The top part of the rice plants is bent. Consequently, it is clear that the true vegetation volume of maize and rice crops is not homogeneous, as it is assumed by the model.

In addition to the lack of geometrical homogeneity in the vertical distribution of the plant components, the model is also very simple from the electromagnetic point of view, since the interaction between the vegetation elements has been taken into account only partially by means of a statistical modeling of the total first order backscattering response of the medium. Actually, this interaction leads to multiple scattering effects which have been demonstrated with simulations and experiments in the literature. The presence of multiple scattering leads to important features in the backscattering response from such targets. At first instance, 


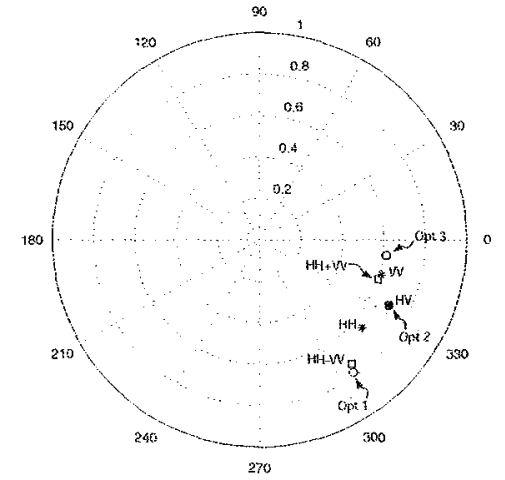

(a)

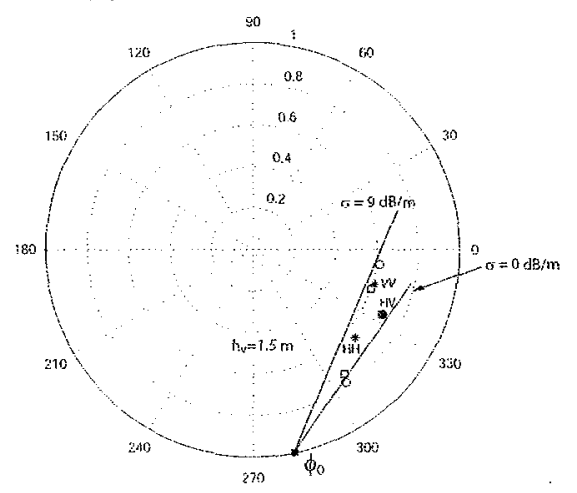

(d)

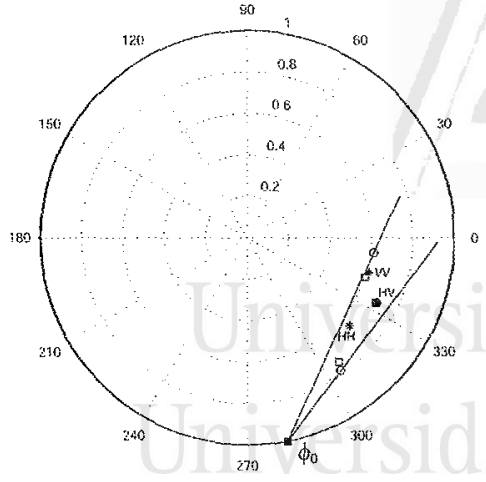

(b)

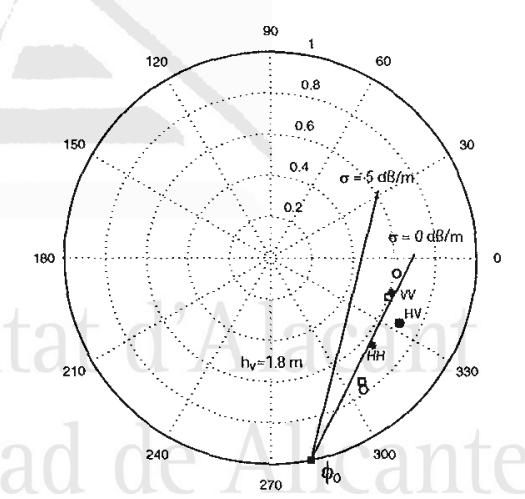

(c)

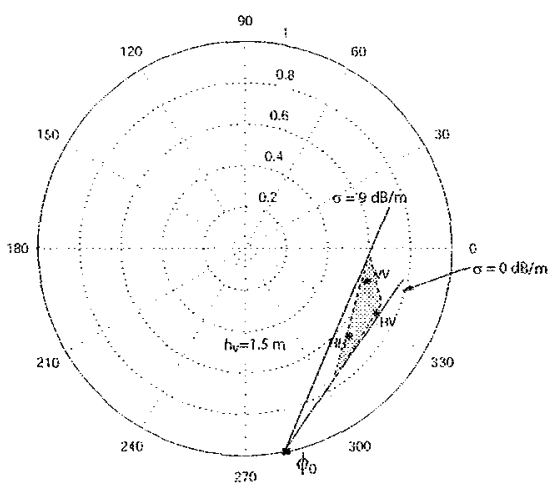

(e)

Figure 5.5: Experimental coherences on the complex plane for the corn sample. Parameters: $f=$ $3 \mathrm{GHz}, B=0.5^{\circ}, k_{z}=1.56$. (a) Coherences for linear basis, Pauli basis and optimized ones. (b) Possible lines from the exact topographic phase. (c) Overlay of the theoretical region with $h_{v}=1.80$. (d) Overlay of the theoretical region with $h_{v}=1.50$. (e) Overlay of the visible region and the theoretical region with $h_{v}=1.50$.

multiple scattering changes the total value of the radar cross section (RCS) of the plants. For example, this was shown in [TOZK90], where coherent effects were noticed by simulating the electromagnetic response of rice fields with clusters of cylinders. Since the definition of the interferometric coherence normalizes the RCS, the influence of multiple scattering in the coherence (both in amplitude and phase) is not produced by the total RCS, but by the vertical profile or distribution of RCS values. For example, the high resolution radar images obtained in $\left[\mathrm{BOM}^{+} 03\right]$ for wheat plants illustrate the presence of second-order volume scattering events. In particular, the commented anomaly in the HV coherence could be explained by the strong multiple scattering present at this channel. Figure 5.7 illustrates qualitatively the effect of multiple scattering on the vertical distribution of phase centers. Multiple scattering produces additional signal contributions that arrive later to the radar than direct scattering contributions. Consequently, there appear additional phase centers which broaden their total distribution as illustrated in Figure 5.7.

After examining the constraints of the inversion problem, a retrieval procedure for the ori- 


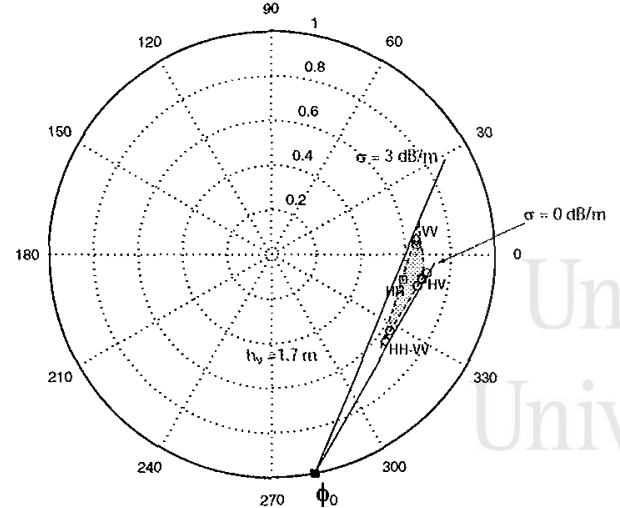

Maize

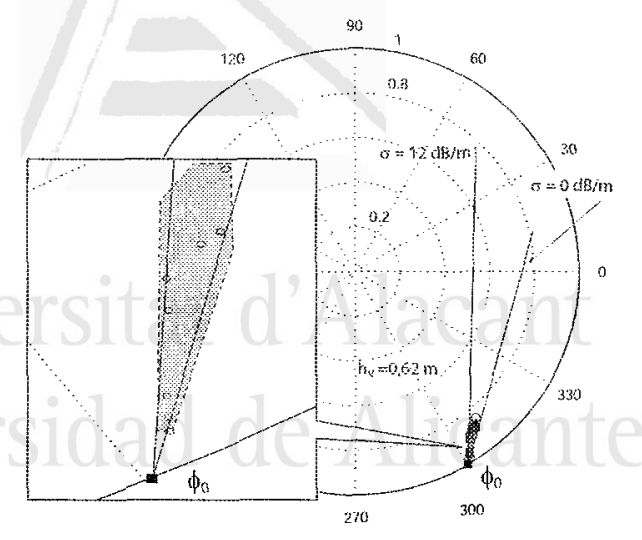

Rice

Figure 5.6: Visible region of the coherences for the maize sample ( $\left.f=6 \mathrm{GHz}, B=0.25^{\circ}\right)$ and the rice sample $\left(f=8 \mathrm{GHz}, B=0.5^{\circ}\right)$.

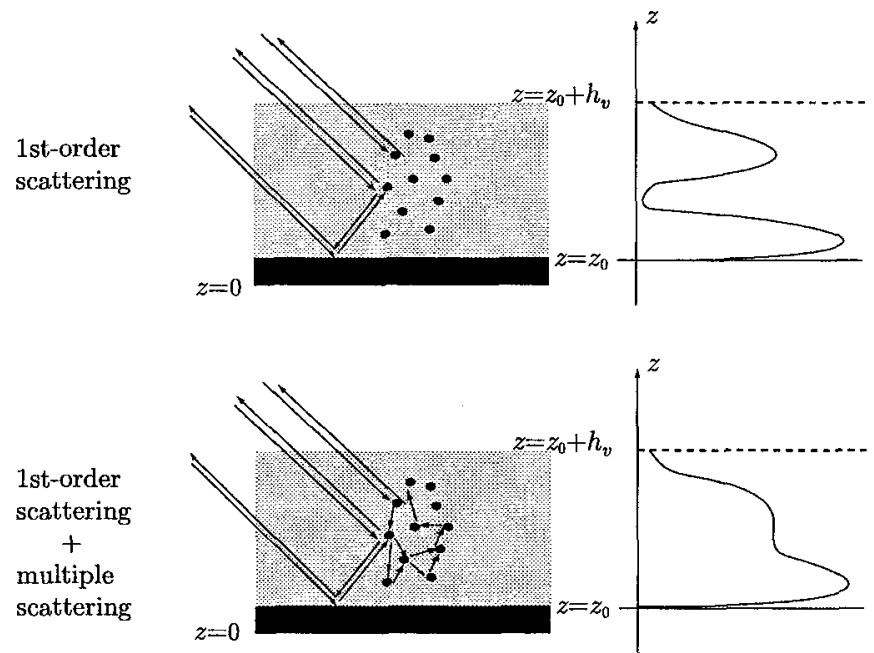

Figure 5.7: Illustration of the effect of multiple scattering on the phase center distribution.

ented volume over ground model is proposed. In the following sections some different strategies proposed in this thesis are also described.

\subsubsection{Geometrical Approach}

The geometrical approach is just based on the distribution on the complex plane of the coherences defined in (5.19), and leads to a clear and powerful physical interpretation of the model, which in turn has helped importantly the subsequent inversion approach [PCOI, $\mathrm{CPO} 3]$.

The steps of the proposed inversion scheme are shown in Fig. 5.8. First, the measured coherences are plotted on the complex plane (see Fig. 5.8.a). Second, as in the scheme of the random volume over the ground, the first physical parameter to be retrieved is the ground 
topography. The straight line best fitting, in a least squares sense, the set of coherence points (see Fig. 5.8.a) is obtained. The intersection between the line and the unit circle defines the phase of the ground position $\phi_{0}$, which is directly converted to topographic height $z_{0}$ by the following expression: $z_{0}=\phi_{0} / k_{z}$.

It must be noted that this inversion scheme requires the triangle to be both long and narrow enough in order to minimize the error in the least squares fitting. This requirement sets a minimum visible line length, as defined in [OP03], which is directly proportional to the dynamic range of the observed ground-to-volume ratios $\mu$. Therefore, the retrieval of a precise estimate of the ground topography by means of the line approach requires to treat with some, at least one, high ground-to-volume ratio $\mu$, which results in coherence points located very close to the unit circle, as well as at least one second channel with a very much smaller $\mu$.

On the other hand, in case of short agricultural crops such as rice, one single channel with a high $\mu$ can provide directly an estimate of the topographic phase. As a rule of thumb, with $\mu \geqslant 10$, a highly accurate estimate of the ground topography can be obtained. This requirement should be taken into account when selecting the polarizations to compute the interferometric coherence. In the case of agricultural fields, with dominant vertical stems, the double bounce contributions to the backscattering, coming from the ground-stem and the stem-ground interactions, are very strong. Both contributions show a dihedral-like behavior, and their scattering mechanism is represented by the HH-VV (or VV-HH) channel. In addition, since the associated phase center is located theoretically at the ground interface [WSL 98], its separation from the rest of coherence points should be enough to ensure a proper estimation of the ground topography by the line fitting, i.e. it provides a sufficient visible line length.

It is important to note that the inclusion of more polarization channels (Pauli, optimized, etc.) to improve the parameter inversion is well founded in the RVoG model case because all possible polarizations and their combinations exhibit the same extinction $\sigma$ (so they lie along the same line) but different values for the ground-to-volume ratio $\mu$, which is very dependent on polarization. However, the analytical expressions of the OVoG model are valid only for the eigenpolarizations (see Section 5.1) and, by definition, not for the rest of polarization combinations. Anyway, if we overlook this theoretical limitation and calculate the coherences for the Pauli basis and the optimized channels, the experiments have shown that they still lie on a narrow region. Therefore, this extension has been used for ensuring a good line fitting, thus providing an accurate estimate of the topographic phase $\phi_{0}$.

Some strategies of line fitting have been implemented and compared in [UBBLSOS]. The best one is the so-called Total Least Squares, which consists of fitting the real and the imaginary parts of the complex coherence points as points in the plane $\mathbb{R}^{2}$.

Once the topographic phase $\phi_{0}$ is determined, all possible lines crossing $\exp \left[j \phi_{0}\right]$ and a measured coherence point, are plotted. The set of lines intersecting the estimated topographic phase is enclosed in the triangular feasible region shown in Fig. 5.8.b. Note that, according to the previous explanation about the region occupied by the coherence points, the points at 


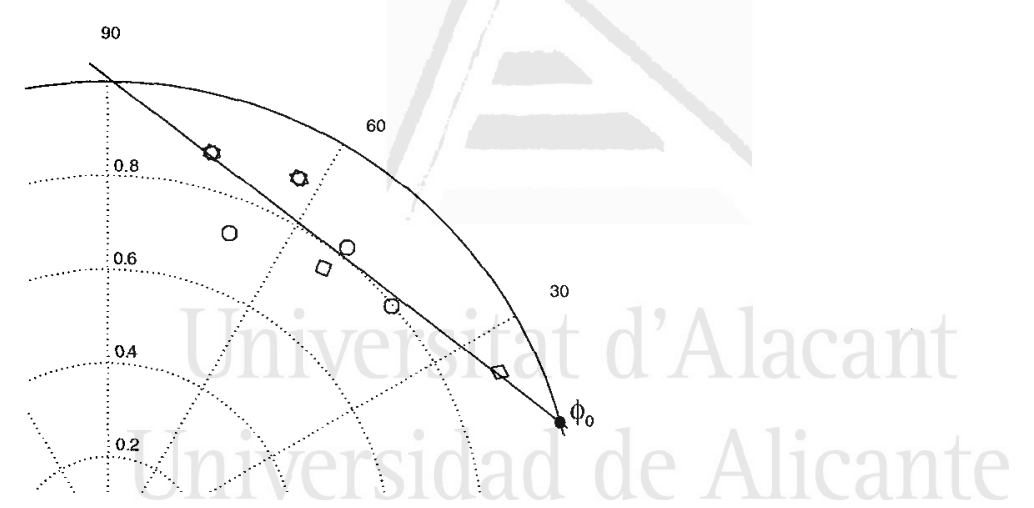

(a)

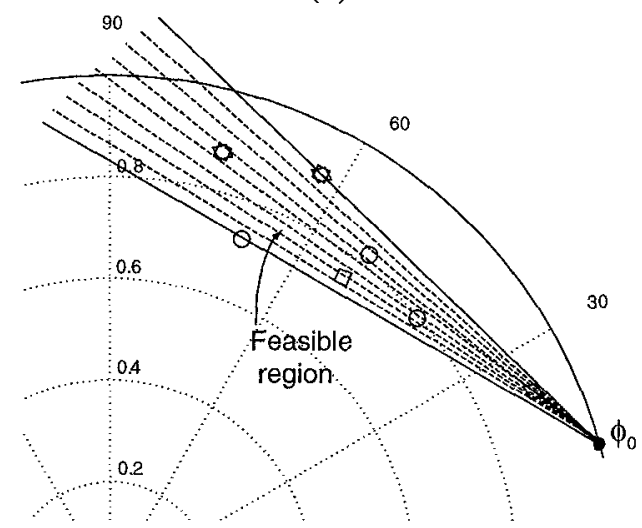

(b)

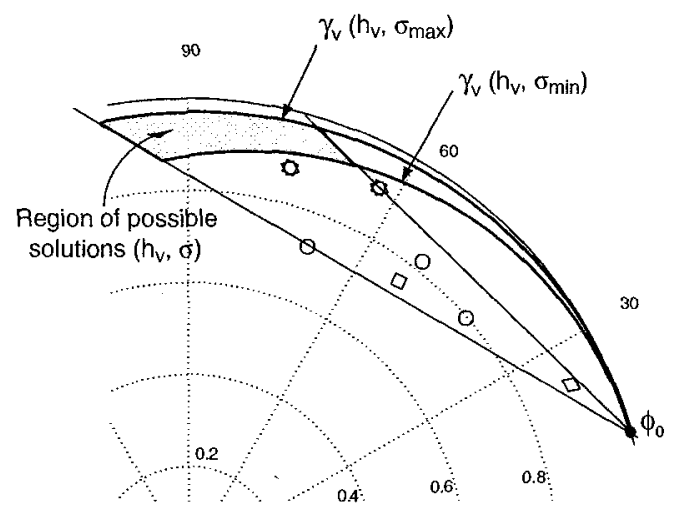

(c)

Figure 5.8: Proposed inversion algorithm for agricultural vegetation. (a) Line fitting and ground topography estimation. (b) Set of lines containing coherences and topographic phase $\phi_{0}$. (c) Representation of the volume coherence for extreme extinction values, $\gamma_{v}\left(h_{v}, \sigma_{\min }\right)$ and $\gamma_{v}\left(h_{v}, \sigma_{\max }\right)$, and region of possible solutions for the vegetation height $h_{v}$.

the right end are those with minimum extinction coefficient $\sigma_{m i n}$, whereas the points at the left end show the maximum extinction coefficient $\sigma_{\max }$. All these straight lines correspond to a unique vegetation height $h_{v}$, which is still unknown. 
The estimate of the vegetation height $h_{v}$ is obtained as follows. A set of volume coherence functions $\gamma_{v}$, departing from the unit circle ground topographic point, is plotted as a function of two variables: $h_{v}$ and $\sigma$. The range of extinctions goes from $\sigma_{\min }=0 \mathrm{~dB} / \mathrm{m}$ (i.e. no attenuation) up to $\sigma_{m a x}$, which is defined as the maximum value reported in the literature for this vegetation type, if known [UTS87, PS05]. Finally, the functions $\gamma_{v}\left(h_{v}, \sigma_{\min }\right)$ and $\gamma_{v}\left(h_{v}, \sigma_{\max }\right)$ are also plotted as a function of height $h_{v}$, as shown in Fig. 5.8.c. The area of the complex plane delimited by the two extreme lines and the two extreme volume coherences defines the region with a feasible retrieval of vegetation height $h_{v}$. From this set of possible solutions, an average height estimation $h_{v}$ and its associated standard deviation $\sigma_{h_{v}}$ are finally estimated.

It is important to remark that a different extinction coefficient has to be estimated for each polarization. Moreover, this algorithm is not too much sensitive to this parameter, as demonstrated by the narrowness of the feasible region of the complex coherence. That is, an important increase of the extinction (say $1 \mathrm{~dB} / \mathrm{m}$ ) results in a negligible displacement of the coherence in the unit circle.

There is another important difference between the proposed inversion algorithm and the one proposed in [CP03]. In the inversion examples described in [CP03], the set of candidate solutions $\left(h_{v}, \sigma\right)$ split into physical and non-physical candidates (see Fig. 5.9). Specifically, in forest experimental observations, the separation between valid and non-valid solutions is fixed by the HV channel, which comes from the top canopy (and it is known that this channel does not include any ground contribution).

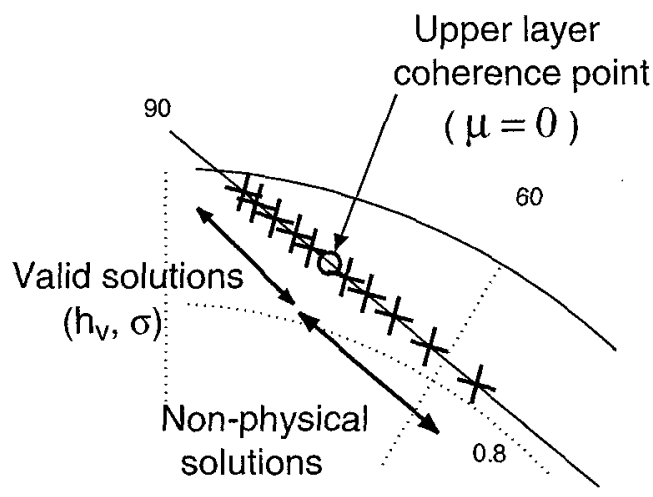

Figure 5.9: Valid solutions for the random volume model.

In case of agricultural crops, all the observed coherences are far from the intersection points between the straight lines and the volume coherence curves. This difference is due to the physical characteristics of the agricultural fields. The morphology of agricultural plants (see Section 5.3.1) consists of a short homogeneous volume which introduces low attenuation. As a result, the total backscattering power comprises contributions coming from the whole vegetation extent, i.e. the upper and lower layers responses are equally present. This is the vegetation behavior for all polarizations. In particular, since the ground contribution is 
low cross-polarized, the scattering phase center of the HV channel will be located approximately in the middle of the vegetation volume. The aforementioned uniform distribution of the backscattering power along the height dimension is in contrast with the backscatter profiles of forest areas, where the response is clearly dominated by the top canopy (see Fig. 2 in [CP03] and [RMOO]). This issue will be analyzed in Chapter 6.

It is also important to make clear that the associated target vectors in the feasible region are arranged in a different way from those in [CP03]. It can be observed in Figure 5.5.a, where the positions of the coherences on the complex plane are plotted for a particular combination of frequency and baseline. Here, the dihedral-like HH-VV target vector is that closer to the topographic phase, and the direct contribution $\mathrm{HH}+\mathrm{VV}$ is at the opposite end. In addition, as mentioned above, it is observed that $\mathrm{HV}$ channel remains at an intermediate zone along the the line. Hence, this feature makes impossible, in the case of an oriented volume, the use of the cross-polar channel as the complex coherence physically corresponding to the upper layer of the vegetation.

Finally, it must be noted that an alternative geometrical approach has been introduced in [HCOS] In that case, these parameters are related with the angle formed by the lines corresponding to the eigenpolarizations.

\subsubsection{Numerical Approach}

If the scene corresponds to the RVoG model, where the extinction is polarization independent ( $\sigma_{\mathrm{w}}=\sigma$ for all polarizations), the model is fully described by six parameters: topographic phase $\phi_{0}$, vegetation depth $h_{v}$, extinction $\sigma$, and ground-to-volume ratios for the three channels: $\mu_{H H}, \mu_{H V}$ and $\mu_{V V}$. In that case, a numerical method for inverting the model can be implemented (minimizing the distance between observations and model predictions), since the number of independent observations, i.e. real and imaginary parts of the three polarization channels, is equal to the number of parameters.

As it is well described in [PCO1], the conditioning of the inversion problem relies on the separation of the effective scattering centers of the selected polarizations. As a result, better results can be obtained if one chooses polarizations with clear separations, which can be decided on a physical basis (e.g. Pauli basis provides direct scattering $\mathrm{HH}+\mathrm{VV}$ located at the volume and dihedral scattering HH-VV located at the ground height) or on mathematical foundations (e.g. polarizations that optimize the coherence). Note that this freedom in the polarization selection is based on the independence of extinction with respect to polarization.

Taking additional profit of these characteristics, a complementary approach consists in increasing the number of polarimetric channels employed in the inversion (not only three), since each additional channel provides two real data (real and imaginary parts of the coherence) and only one extra parameter (its ground-to-volume ratio). This can be applied when inverting the RVoG model by using the geometrical method, but the drawback of this 
Chapter 5. Retrieval of Biophysical Parameters by Using PollnSAR and Simple Models

approach is the growth of the dimensionality of the problem, which may complicate its numerical solution.

When the scene corresponds to the OVoG model (i.e. extinction is polarization dependent), there appears an indetermination in the problem. The observation space is the same as before (six real data), but there are two different extinctions to be determined $\left(\sigma_{H}\right.$ and $\left.\sigma_{V}\right)$, thus increasing the number of parameters to seven. In addition, the formulation of the model is suited only for the eigenpolarizations ( $\mathrm{H}$ and $\mathrm{V}$ ), so, in principle, the rest of polarizations cannot be used to enlarge the observation space as before. The problem of this inversion approach is two-fold: there are more parameters than measured data, and the scattering centers corresponding to these data are not specially well separated in height. The situation of the OVoG direct model described so far corresponds to the block diagram shown in Fig. 5.10.

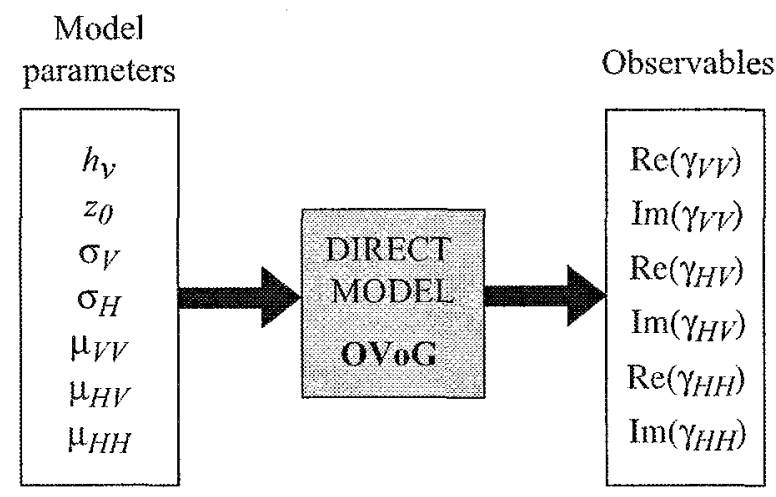

Figure 5.10: Block diagram of direct model.

These limitations will be analyzed later and some solutions will be proposed.

\subsubsection{Hybrid Approach}

In order to solve the aforementioned indetermination of the inverse problem in the OVoG case, it is also proposed in this work an hybrid algorithm (geometrical and numerical) which can be divided into two sequential steps, as depicted in Fig. 5.11.

First, the line fitting is applied to an extended set of polarizations (linear, Pauli and optimized) and the topographic phase $\phi_{0}$ is estimated. We cannot state that this approach is strictly valid in the OVoG model, because the analytical expressions of the OVoG model are valid only for the eigenpolarizations. Anyway, if we overlook this theoretical limitation and calculate the coherences for the Pauli basis and the optimized channels, the experiments have shown that they still lie on a narrow region. Therefore, this extension has been used for ensuring a good line fitting, thus providing an estimate of the topographic phase $\phi_{0}$. In summary, by assuming that the distribution of coherences is similar to that of the RVoG model, we estimate the topographic phase or, equivalently, the ground position $z_{0}$. 


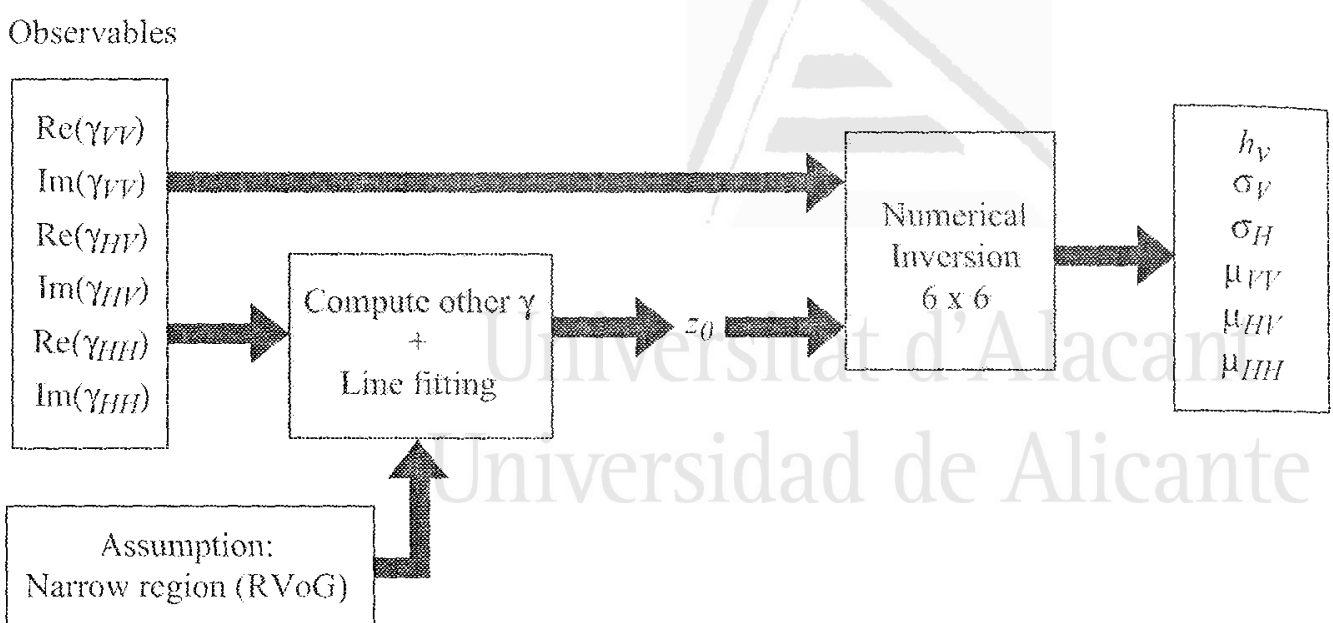

Figure 5.11: Block diagram of inversion algorithm based on the hybrid approach.

Second, once we know one of the seven parameters, a numerical optimization algorithm is applied to find a solution for the remaining six parameters $\left(h_{v}, \sigma_{H}, \sigma_{V}, \mu_{H F}, \mu_{V V}\right.$ and $\mu_{H H}$ ), by using the set of six real values provided by the linear polarizations (i.e. real and imaginary parts of the coherences). Note that the inverse problem is clearly nonlinear and not well conditioned, so multiple solutions can be found and iterative approaches present a strong dependence on the initial solutions. Note that a different geometrical approach was introduced in [HCO4], which relates these parameters with the angle formed by the lines corresponding to the eigenpolarizations.

Alternatively, an additional inversion approach based on a multibaseline configuration of the interferometer has been tested. When the baseline is changed, it is expected that all electromagnetic properties of the scene remain unmodified: extinctions and ground-to-volume ratios. Consequently, if the observation space is increased by adding a second interferometric baseline, a total of twelve input real data are available for the inversion algorithm to estimate seven model unknowns.

The obtained results are discussed in next section.

\subsection{Experimental Results}

\subsubsection{Indoor Measurements}

The proposed inversion schemes have been tested experimentally with indoor wide-band polarimetric measurements on samples of corn and rice fields. All measurements have been conducted in the European Microwave Signature Laboratory (EMSL), at JRC-Ispra, Italy.

The corn sample consists of a stand of $6 \times 6$ young plants about $1.8 \mathrm{~m}$ high, uniformly planted 
in a square container of side length $2 \mathrm{~m}$. Separation between plants is about $30-35 \mathrm{~cm}$. The plants show a green vertical fresh trunk with diameter about $4 \mathrm{~cm}$. The stems carry wide leaves from a height of $40 \mathrm{~cm}$ up to the top. The leaves are about $30-40 \mathrm{~cm}$ long and $7-8 \mathrm{~cm}$ wide, and are oriented approximately at $20^{\circ}-45^{\circ}$ with respect to the trunk, as shown in the photograph in Fig. 5.12.a.

The rice sample is composed by $10 \times 10$ plants of about $0.75 \mathrm{~m}$ high, uniformly distributed in a square container with side length $1 \mathrm{~m}$. Each plant presents a cluster of green stems or long leaves that originates directly from the ground. In the upper half of the sample, these stems are notably bent and oriented in a random fashion. The leaves are about $2 \mathrm{~cm}$ wide. The soil was permanently flooded to replicate the natural conditions of rice crops. A photograph of this target is shown in Fig. 5.12.b.

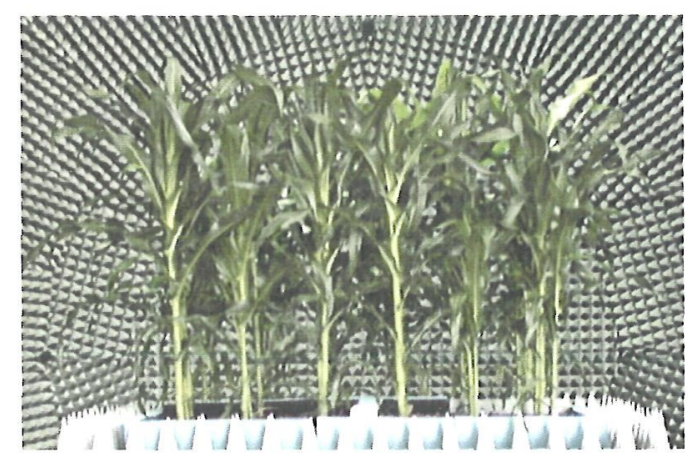

(a)

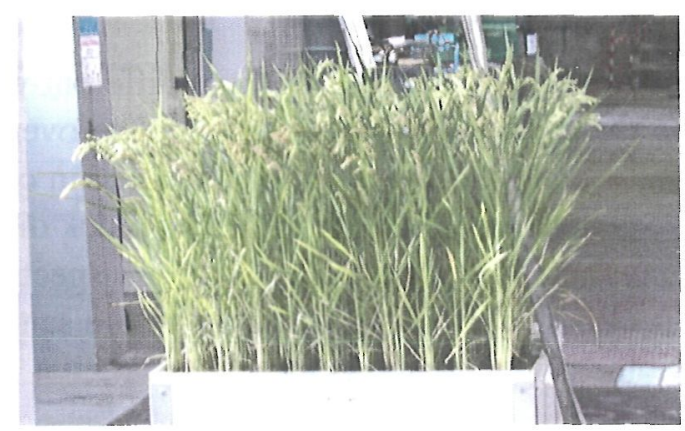

(b)

Figure 5.12: Photographs of the agricultural samples measured at the EMSL: (a) Corn. (b) Rice.

The measurement set-up used in the experiments is depicted in Fig. 5.13. The vegetation sample was mounted on a rotating platform inside the anechoic chamber. The measurement system is based on a network analyzer and operates in the stepped-frequency mode. During the measurements the sample was rotated about a vertical axis by $360^{\circ}$ in azimuth, acquiring the polarimetric radar backscatter at 72 angles with a step of 5 degrees $^{1}$. The frequency ranged from 2 to $9 \mathrm{GHz}$. The elevation incidence angles ranged from $44^{\circ}$ to $45^{\circ}$ with a step of 0.25 degrees, thus enabling an interferometric analysis.

It must be noted that the images employed in these results have been obtained with low resolution because the whole vegetation sample must be confined inside a single resolution cell. To satisfy this requirement, the focused images of the maize are centered at $0.50 \mathrm{~m}$ above the EMSL focus. As a result, the true ground topographic height of the maize sample is $-0.88 \mathrm{~m}$, since the ground is $0.38 \mathrm{~m}$ below the EMSL focus (see Figure 5.13 ). On the other hand, the images generated in the rice experiment are centered just at the focus. In this case, the flooded ground was located $0.24 \mathrm{~m}$ below the focus.

It must be pointed out that range spectral filtering, which is very common in real applications,

\footnotetext{
${ }^{1}$ These experimental data are freely available to the scientific community at the website www-emsl.jrc.it.
} 


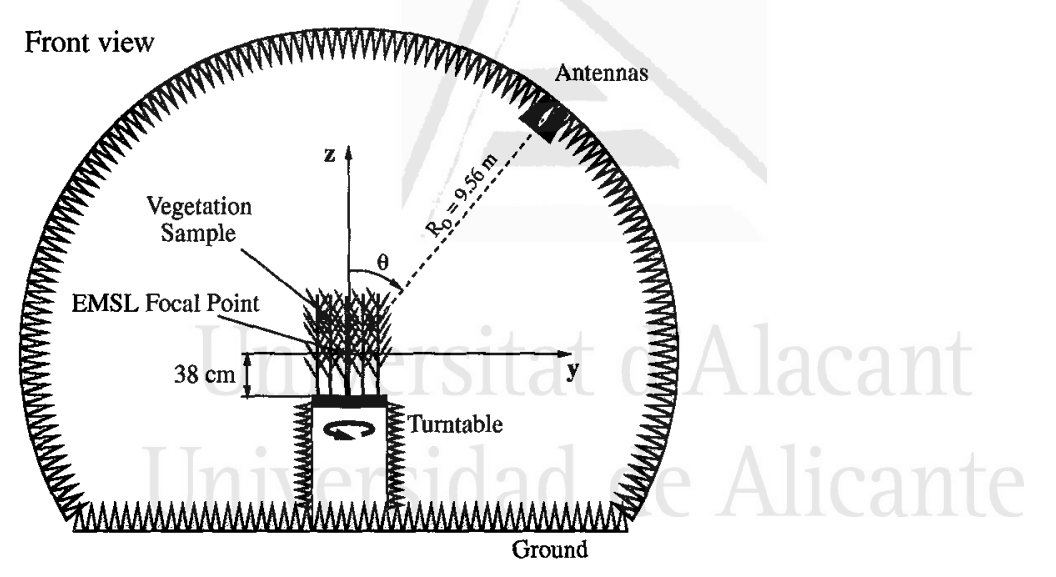

Figure 5.13: Setup of the experiments at the EMSL.

is also applied here but in a different way. Since wide-band measurements are available in the frequency domain, a complete overlap of the spectra corresponding to both images can be achieved if an a priori calculation of the spectral shift when changing the viewing angle is performed. In Figure 5.14 a block diagram illustrates the pre-processing steps prior to the coherence estimation. Once the spectral displacement $\Delta f$ is known, the second image is obtained, which is made up by the same spectral components as in the first image and with the original bandwidth.

\subsubsection{Inversion Results with the Geometrical Approach}

The tests of this estimation procedure have been carried out by using eight different coherence values, corresponding to the lexicographic linear basis ( $\mathrm{HH}, \mathrm{HV}$ and VV), the Pauli basis (HH+VV, HH-VV and HV (repeated)), and the three polarizations provided by the coherence optimization.

As a starting point, the inversion algorithm is illustrated with real data from the maize sample in Figure 5.15, obtained with a baseline of $0.25^{\circ}$ and a frequency of $4.5 \mathrm{GHz}$. The corresponding vertical wavenumber is $k_{z}=1.16$.

The optimized coherences are represented by circles, the Pauli coherences by diamonds, and the lexicographic ones by squares. The least-squares fitting is applied to the full set of coherence points. This line crosses the unit circle at $\phi_{0}=-50.87^{\circ}$. This phase is converted to height and it results in $-0.76 \mathrm{~m}$, which is close to the true topographic height $(-0.88 \mathrm{~m})$. Then, the possible region of coherences is estimated. It is delimited by two extreme dotted straight lines that intersect this point and that enclose all coherence points. Finally, the feasible region of volume coherences (shaded in the picture) is defined by these lines and by the curves representing the volume coherence functions (also plotted in the picture). From the set of possible estimates of the vegetation height, the estimated average height is $1.65 \mathrm{~m}$, and the standard deviation is $0.09 \mathrm{~m}$. Both statistical estimates are computed over the complete 


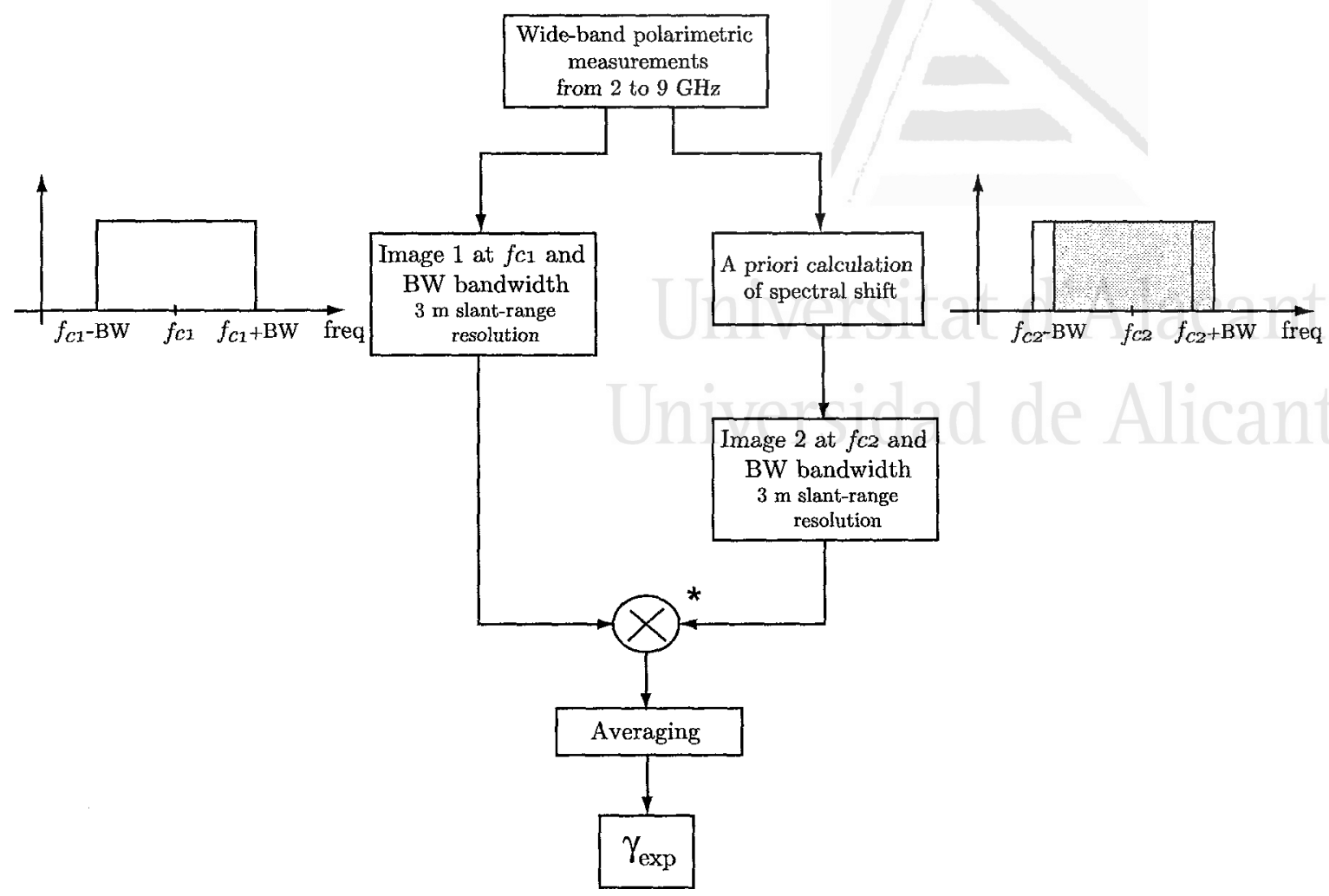

Figure 5.14: Block diagram for the spectral overlap in the interferometric pair.

set of possible solutions. On the other hand, if the estimation procedure based on the line fit [ $\left.\mathrm{CPO}_{2}^{3}\right]$ is applied, and assuming a random volume with zero extinction, $\sigma=0$, a single height value is retrieved which corresponds to $1.75 \mathrm{~m}$.

After illustrating the procedure, the discussion of the inversion results obtained as a function of frequency and baseline is next.

\subsubsection{Corn Sample}

Figure 5.16 shows the estimates of topographic and vegetation height with a baseline $B=$ $0.25^{\circ}$. In general, both parameters can be estimated at all frequencies from 2 to $9 \mathrm{GHz}$, although the vegetation height is retrieved more precisely in the frequency range 3 to $8 \mathrm{GHz}$, with an accuracy about $12 \%$. The retrieved ground topography is always slightly over its true value (about 10 to $20 \mathrm{~cm}$ above, i.e. an accuracy about $11 \%$ to $22 \%$ ), and exhibits some small fluctuations. The mean and standard deviation of the set of possible $h_{v}$ solutions, as well as the estimates provided by the random volume over ground model with $\sigma=0$, have been calculated and depicted too. Note that in all figures in this Chapter showing the height and topography estimates, the retrieved values are plotted independently on the same graph, i.e. the depth of the vegetation layer corresponds directly to the estimated height function. 


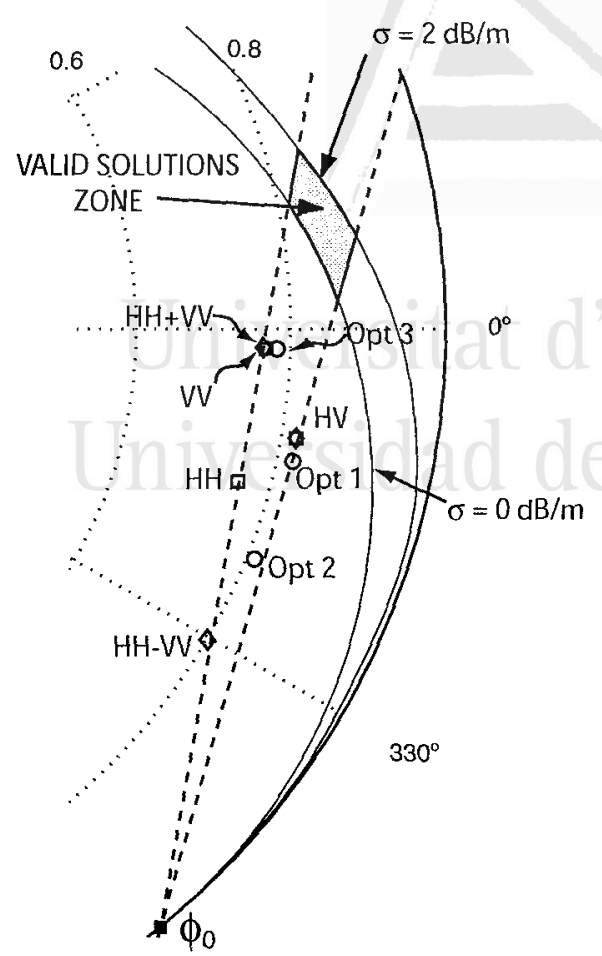

Figure 5.15: Example of the inversion algorithm with data from the corn sample. $f=4.5 \mathrm{GHz}$, $B=0.25^{\circ}, k_{z}=1.16$.

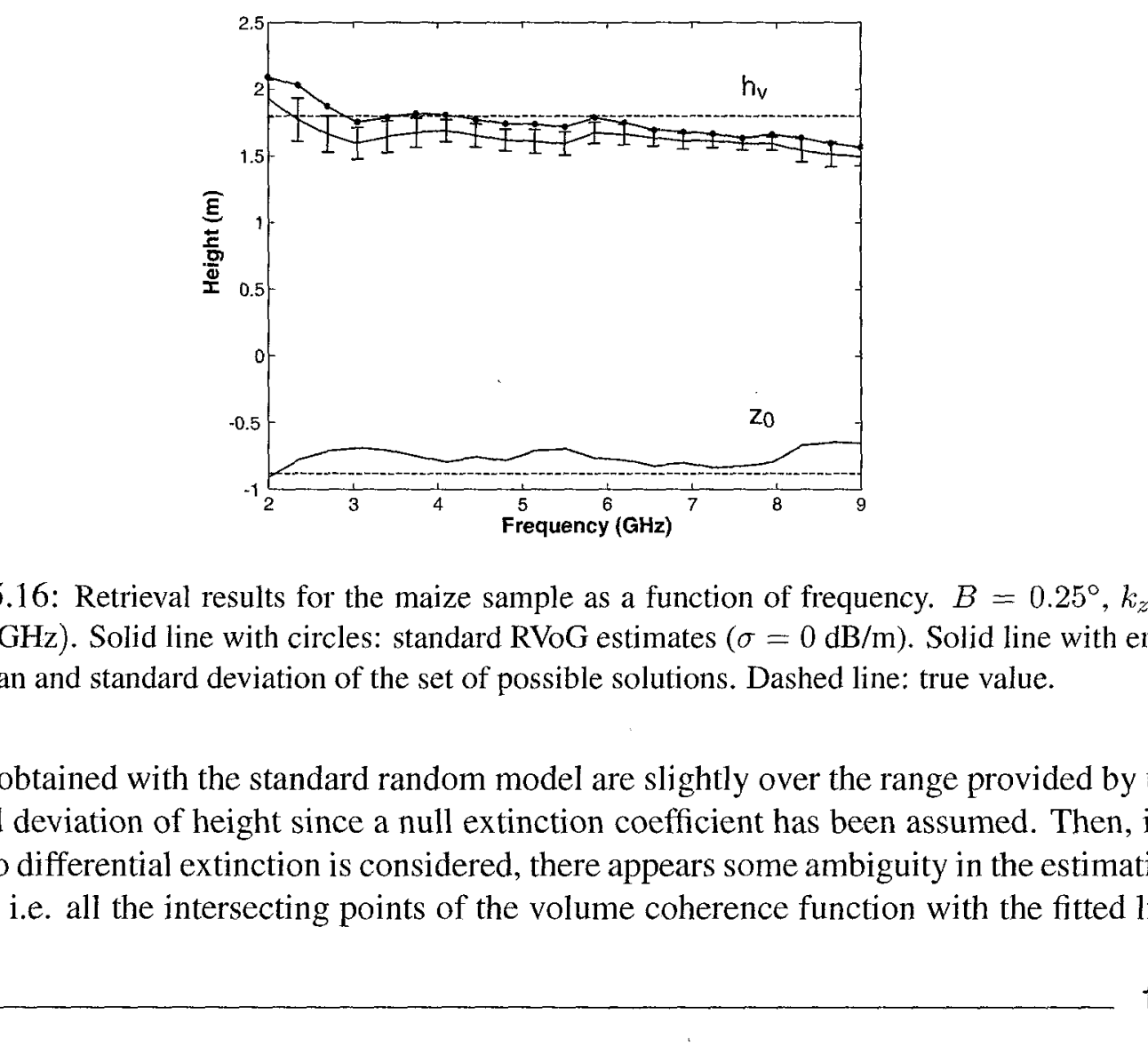

Figure 5.16: Retrieval results for the maize sample as a function of frequency. $B=0.25^{\circ}, k_{z}=$ $0.26 \cdot f(\mathrm{GHz})$. Solid line with circles: standard $\mathrm{RVoG}$ estimates $(\sigma=0 \mathrm{~dB} / \mathrm{m})$. Solid line with error bars: mean and standard deviation of the set of possible solutions. Dashed line: true value.

Results obtained with the standard random model are slightly over the range provided by the standard deviation of height since a null extinction coefficient has been assumed. Then, if a non-zero differential extinction is considered, there appears some ambiguity in the estimation process, i.e. all the intersecting points of the volume coherence function with the fitted line

(n)
B $=0.25{ }^{\circ}, k_{2}=1.16$ .

. .

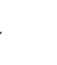

.


are located above the set of complex coherence points, and then, the solution must be given in terms of mean value and its associated standard deviation.

However, it is evident that the estimates provided by the RVoG model (assuming null extinction) are also satisfactory. If one decides to use these estimates as final solutions of the retrieval procedure, the oriented volume algorithm would provide a measure of the variance of these solutions as a consequence of the non-zero differential extinction coefficient.

The differences of $h_{v}$ and $z_{0}$ with the ground truth are below $20 \mathrm{~cm}$ within this frequency range. The retrieved $h_{v}$ decreases as the frequency increases. This is due to the increasing attenuation, which reduces the contribution from the bottom layers. Consequently, the effective vegetation depth is smaller. At very low frequencies, in contrast, the response from the canopy is low and the algorithm is not sensitive enough to the vegetation volume.

With the larger baseline $B=0.5^{\circ}$, the aforementioned trend is more evident. The inverted parameters for the maize sample are plotted for this baseline in Figure 5.17. Both parameters are well estimated (about $11 \%$ height and topography accuracy) only up to $6 \mathrm{GHz}$, approximately. With this baseline and incidence angle, the vertical wavenumber can be calculated as $k_{z}=0.52 \cdot f$, where $f$ is the central frequency, given in GHz. It is important to notice that at $6 \mathrm{GHz}$ this wavenumber is greater than 3 , so the $1.8 \mathrm{~m}$ high corn target generates an extreme volume decorrelation. This volume decorrelation reduces the magnitude of the observed coherences and, as a result, their corresponding phases are noisy. This effect, well known in SAR interferometry, is illustrated in Figure 5.18. With large baselines, the average coherence is very low at high frequencies. Note, however, that the algorithm is able to work properly even with coherences as low as 0.3 .

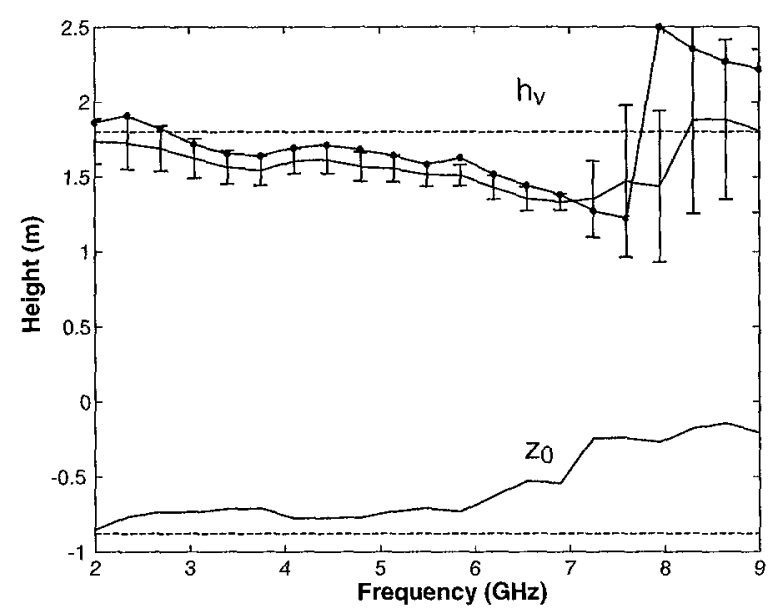

Figure 5.17: Retrieval results for the maize sample as a function of frequency. $B=0.5^{\circ}, k_{z}=$ $0.52 \cdot f(\mathrm{GHz})$. Solid line with circles: standard RVoG estimates $(\sigma=0 \mathrm{~dB} / \mathrm{m})$. Solid line with error bars: mean and standard deviation of the set of possible solutions. Dashed line: true value.

An additional consequence of the frequency increase is the dispersion of the coherence points on the complex plane. This is shown in Figure 5.19, where the position of the coherence 


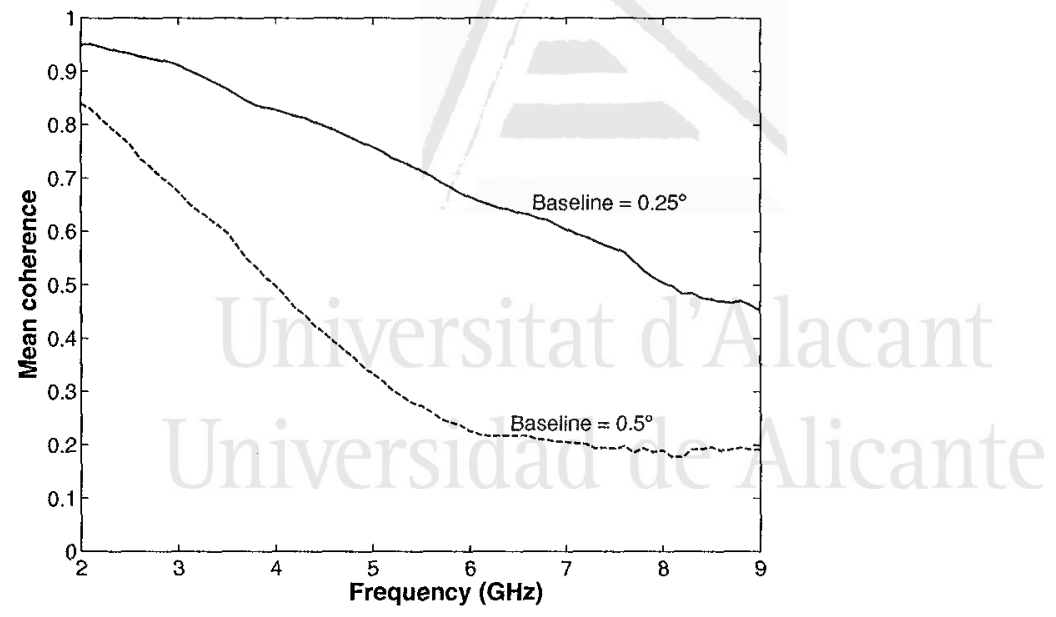

Figure 5.18: Average coherence as a function of frequency for the maize sample.

points is depicted for $2,4,6$ and $8 \mathrm{GHz}$.

It is clearly appreciated that the dispersion of the coherence points increases with frequency. The main drawback of this phenomenon is the difficulty of the line fitting. As explained in Section 5.2.1, the region occupied by the coherence points must be both narrow and long enough. In addition, the significant attenuation at high frequencies and the large baselines minimize the ground contribution. Therefore, it is more difficult to measure a high groundto-volume ratio and, consequently, the ground topography is not estimated accurately.

In summary, the proposed retrieval algorithm can be employed in a wide range of frequencies to retrieve the ground topography and the vegetation height of a scene with corn fields. The apparent limitation of this technique for high frequencies is caused by the volume decorrelation, which depends on the product of the vertical wavenumber $k_{z}$ and the target height $h_{v}$. For example, for a zero extinction target the coherence behaves like a sinc function whose argument is $k_{z} \cdot h_{v}$. Consequently, the product $k_{z} \cdot h_{v}$ should be maintained below a certain threshold. However, this limitation is present only for extreme values, and, with a reasonable selection of baselines, the inversion algorithm has demonstrated to be very robust for a wide range of frequencies.

\subsubsection{Rice Sample}

The inversion results obtained with the rice sample are shown in Figs. 5.20, 5.21 and 5.22, which correspond to baselines of $0.25^{\circ}, 0.5^{\circ}$ and $1^{\circ}$, respectively.

It can be seen that with the small baseline the algorithm is not able to provide estimates of the vegetation height $h_{v}$ below $8 \mathrm{GHz}$. This is because the measured sample is very short and has a very low density, and consequently, the backscatter from the volume is very weak. In this case, the ground-stem interaction is the dominant scattering mechanism due 


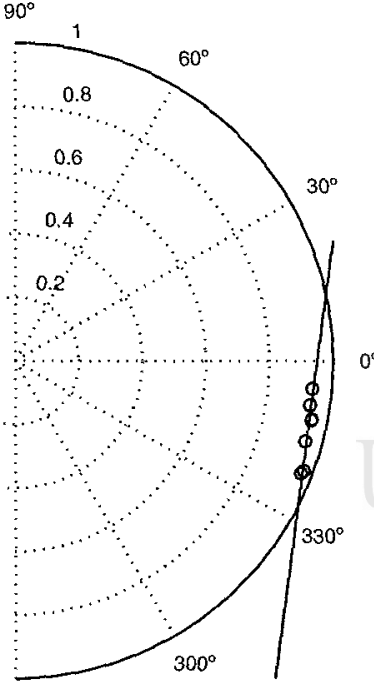

$2 \mathrm{GHz}$

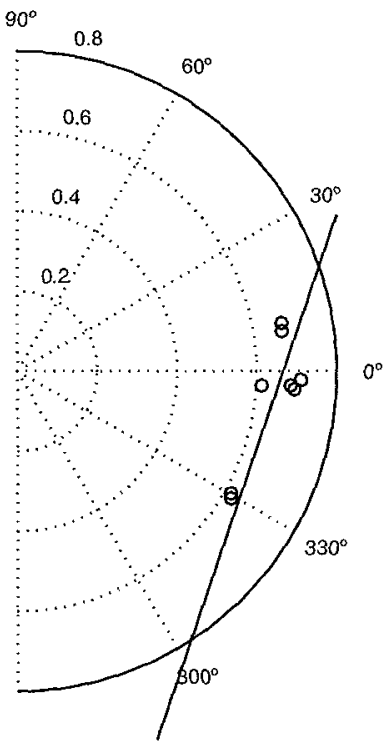

$6 \mathrm{GHz}$

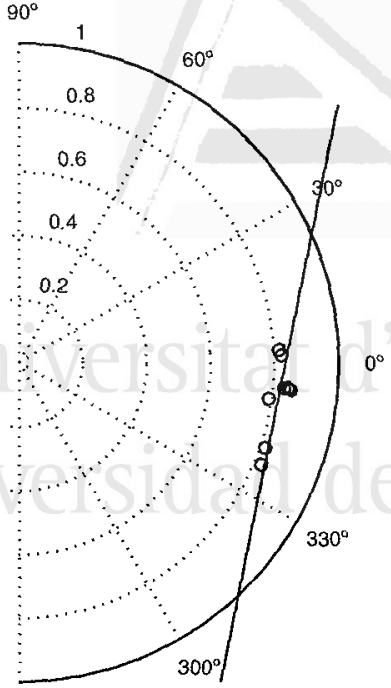

$4 \mathrm{GHz}$

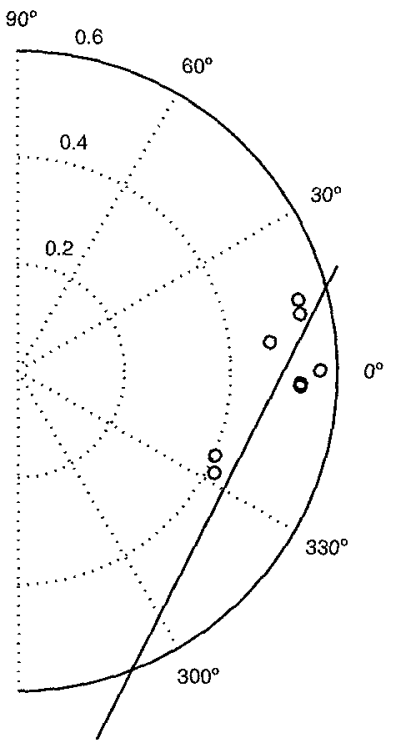

$8 \mathrm{GHz}$

Figure 5.19: Distribution of coherence points in the complex plane at different frequencies. Target: Maize sample. $B=0.25^{\circ}$.

to the presence of water in the flooded soil. This mechanism prevails over the weak direct backscattering from the volume. On the other hand, because of the strong ground-stem interaction, the ground topography can be precisely estimated at all frequencies above $4 \mathrm{GHz}$, with an accuracy better than $4 \mathrm{~cm}(16 \%)$.

To illustrate the estimation of rice parameteres, the resulting cluster of coherence points at $5 \mathrm{GHz}$ with $B=0.5^{\circ}$ is shown in Figure 5.23 . The measured coherences are all concentrated in a small region near the unit circle. This means that the backscattered signal for all polar- 


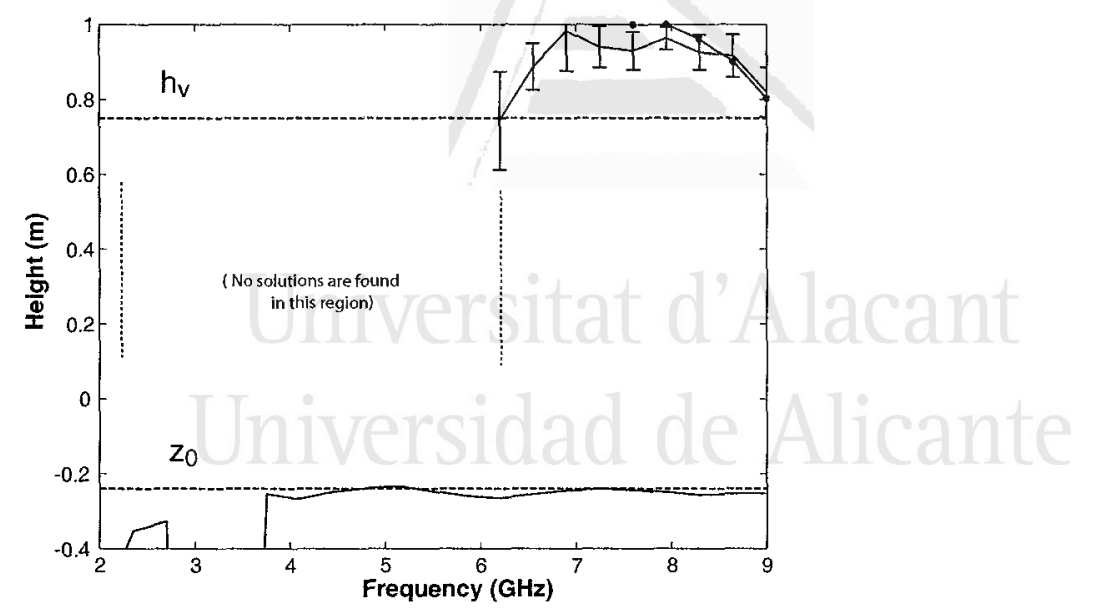

Figure 5.20: Retrieval results for the rice sample as a function of frequency. $B=0.25^{\circ}, k_{z}=$ $0.26 \cdot f(\mathrm{GHz})$. Solid line with circles: standard RVoG estimates $(\sigma=0 \mathrm{~dB} / \mathrm{m})$. Solid line with error bars: mean and standard deviation of the set of possible solutions. Dashed line: true value.

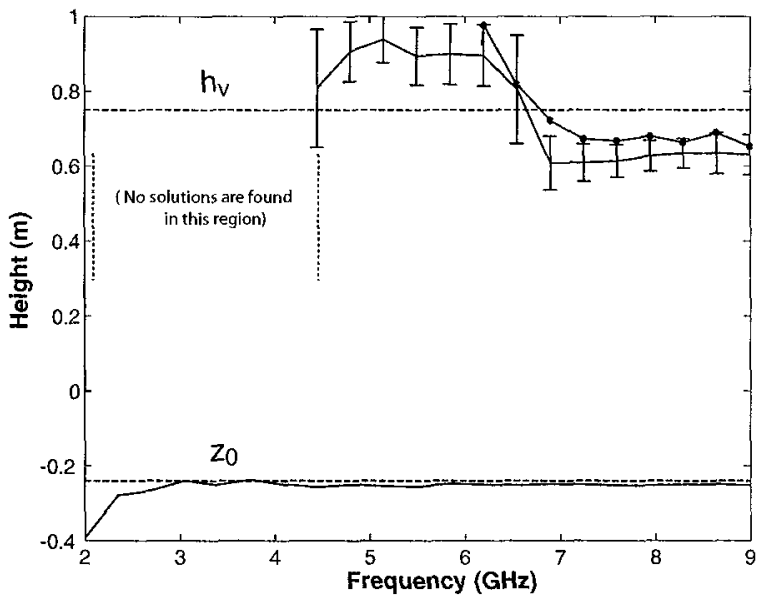

Figure 5.21: Retrieval results for the rice sample as a function of frequency. $B=0.5^{\circ}, k_{z}=$ $0.52 \cdot f(\mathrm{GHz})$. Solid line with circles: standard RVoG estimates $(\sigma=0 \mathrm{~dB} / \mathrm{m})$. Solid line with error bars: mean and standard deviation of the set of possible solutions. Dashed line: true value.

izations is dominated by the ground-stem interaction, whose phase center is located at the ground level. Consequently, the topographic height is easily estimated by directly observing the interferometric phase. However, the retrieval of the height with the line fitting is almost not possible.

Since rice fields are usually shorter than corn fields, a higher $k_{z}$ is needed to become sensitive to its vertical structure, as shown in the inversion results at high frequencies of Fig. 5.21. With the baseline of $0.5^{\circ}$, stable height estimates around $0.65 \mathrm{~m}$ are obtained above $7 \mathrm{GHz}$. The true vegetation height is $0.75 \mathrm{~m}$, giving an accuracy about $13 \%$. This improvement in the inversion performance is a consequence of the larger vertical wavenumber, in conjunction with the stronger response of the canopy at these frequencies. Therefore, the inability of 


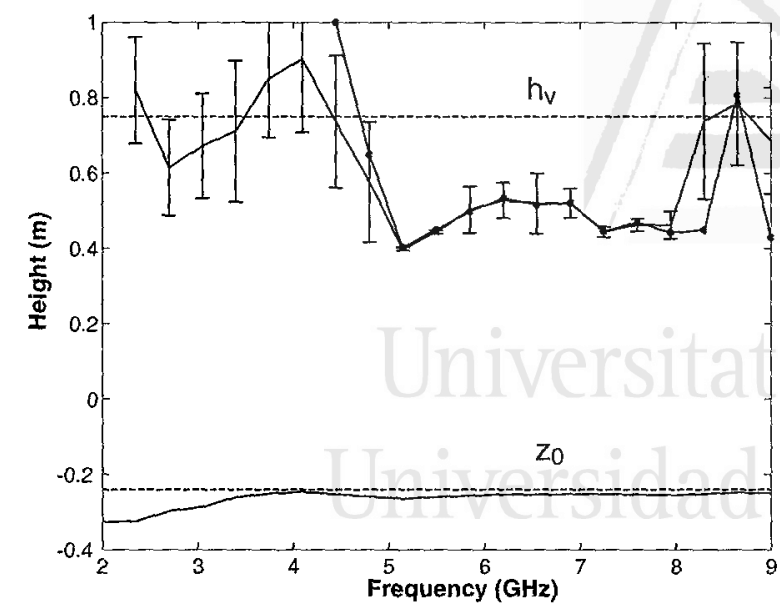

Figure 5.22: Retrieval results for the rice sample as a function of frequency. $B=1^{\circ}, k_{z}=1.04$. $f(\mathrm{GHz})$. Solid line with circles: standard RVoG estimates $(\sigma=0 \mathrm{~dB} / \mathrm{m})$. Solid line with error bars: mean and standard deviation of the set of possible solutions. Dashed line: true value.

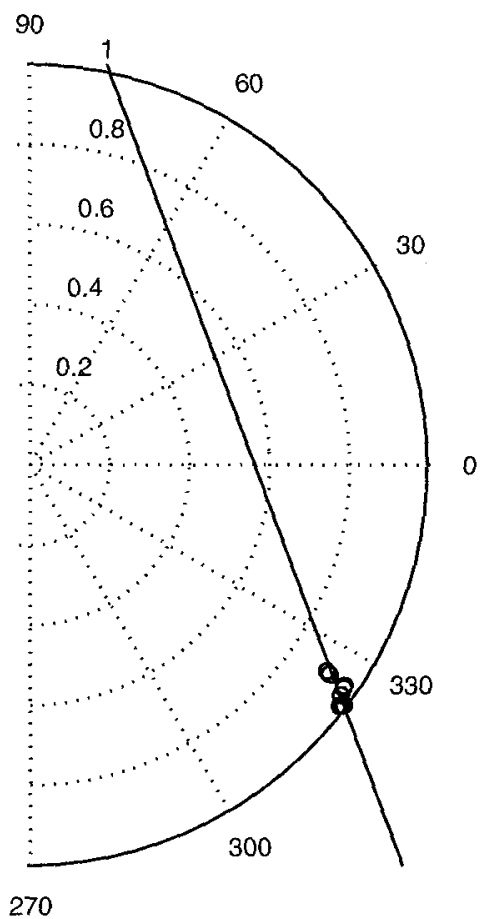

Figure 5.23: Distribution of coherence points in the complex plane for the rice sample at $5 \mathrm{GHz}$ and $B=0.5^{\circ}$.

the procedure to estimate the vegetation height with a short baseline for frequencies below $7 \mathrm{GHz}$ (see Fig. 5.20) is not only due to the weak canopy backscatter, but also to the lack of sensitivity to the vertical structure with such a short baseline. Actually, if a $1^{\circ}$ baseline is used (see Fig. 5.22), it is observed that the algorithm can provide height estimates with a $11 \%$ accuracy even at $\mathrm{S}$-band, as a consequence of the higher vertical wavenumber.

\section{te}


It can be concluded that there exists also a limitation in the minimum $k_{z} \cdot h_{v}$ product that provides enough sensitivity for the retrieval algorithm.

On the other hand, it is also important to remark the extremely stable behavior of the ground topography estimation from $4 \mathrm{GHz}$. The obtained $z_{0}$ estimates do not differ more than $1 \mathrm{~cm}$ (4\% accuracy) in the range $4-9 \mathrm{GHz}$.

\subsubsection{Non-Fully Polarimetric Data}

In order to assess the application of the algorithm to non-fully polarimetric data, this inversion technique has been tested with reduced combinations of polarization channels. Results are presented in Figs. 5.24 and 5.25 with the corn target and a $0.25^{\circ}$ baseline.

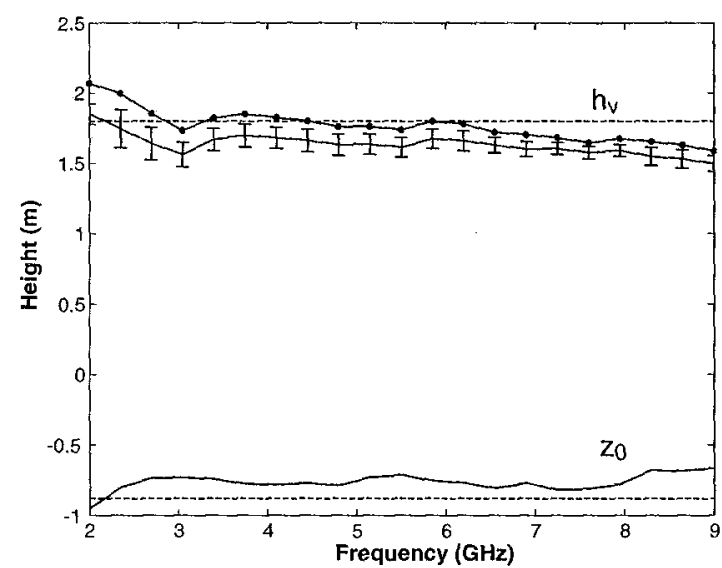

(a)

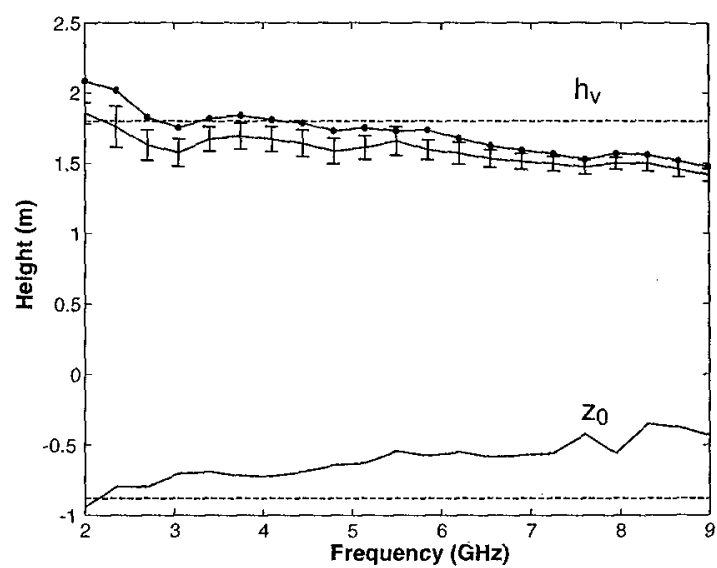

(b)

Figure 5.24: Retrieval results for the maize sample as a function of frequency. (a) Coherence points for the Pauli basis. (b) Coherence points for the lexicographic basis. $B=0.25^{\circ}, k_{z}=0.26 \cdot f(\mathrm{GHz})$. Solid line with circles: standard RVoG estimates $(\sigma=0 \mathrm{~dB} / \mathrm{m})$. Solid line with error bars: mean and standard deviation of the set of possible solutions. Dashed line: true value.

Firstly, the data is assumed to be fully polarimetric, but the number of complex coherence values employed in the algorithm is reduced to three. Fig. 5.24.a shows that the use of only the three channels of Pauli basis yields nearly identical results to those depicted in Fig. 5.16, where eight different polarization combinations were considered. In the case of using the three channels of the lexicographic basis, correct estimation values (about $11 \%$ accuracy) are obtained up to $5 \mathrm{GHz}$, as displayed in Fig. 5.24.b. From that frequency, the response of these polarizations does not provide a good separation of the top of the canopy and the ground, and this leads to worse estimates of vegetation height and topography.

Secondly, reduced combinations of polarimetric channels have been used. In principle, the application of the line model fitting taking into account only two complex coherence values 
does not yield reliable results. This can be observed in Figs. 5.25.a and 5.25.b. It is observed that the inversion process is only applicable within a narrow bandwidth at S-band if $\mathrm{HH}$ and $\mathrm{HV}$ channels are combined. The combination of VV and HV channels only provides good estimates for the maize height in a small frequency band ranging from 3.5 to $5.5 \mathrm{GHz}$. This behavior is explained by the line fitting process itself: when only two points are considered, statistical fluctuations intrinsic to the observables affect more strongly and the visible region reduces to the minimum. Hence, the fitted line can take any orientation. This effect is illustrated in Fig. 5.26.

However, with the elements of the Pauli basis that correspond to direct scattering (HH+VV) and dihedral-type scattering (HH-VV), the performance of the estimation algorithm is much more satisfactory. Thus, the best choice of polarizations is that with the two copolar channels. Fig. 5.25.c shows that the error in the estimated values is reduced to a few centimeters, i.e. $11 \%$ accuracy in the worst case, which is comparable to the accuracy of the inversion procedure with the full set of eight channels.

Notwithstanding the good results obtained with the combinations of the copolar channels, it must be taken into account that the implementation of this solution requires a dual transmitter polarization. This entails some practical limitations such as a halved swath width and the need of a doubled average transmitted power. The former leads to reduced coverages, whereas the latter results in a higher bandwidth in order to overcome the maximum peak power limitation of the system. Hence, dual polarized systems only on receive would be preferred in some cases despite the reduced retrieval performance.

In recent dates, the concept of compact polarimetry has shown an important potential since it can take benefit from the fully polarimetric system without its limitations. Compact-pol systems differ from conventional dual polarized systems in two aspects: retain the relative phase between the two received polarizations, and they may take advantage of diversity between the transmitted and received polarizations. The $\pi / 4$ mode [JCSL05] consists of transmitting a linearly polarized wave at $45^{\circ}$ and then receiving two coherent orthogonal fields at vertical and horizontal polarizations. On the other hand, the hybrid-polarity concept [Rano7] consists of transmitting circular polarization and receiving two orthogonal mutually coherent linear polarizations, such as the vertical and the horizontal ones. Although both concepts overcome the limitations of dual transmitter polarization systems, the hybrid-polarity scheme has shown unique advantages regarding for example to the system calibration. Therefore, compact polarimetry exhibits an important potential for future systems applied to this topic.

\subsubsection{Inversion Results With The Hybrid Approach}

As stated previously in this chapter, the hybrid approach consists of two sequential stages. The first one is a line fitting applied to an extended set of polarizations (linear, Pauli and optimized), which allows to estimate the topographic phase $\phi_{0}$. The second stage is a numerical optimization algorithm applied in order to find a solution for the remaining six parameters 
( $h_{v}, \sigma_{H}, \sigma_{V}, \mu_{H H}, \mu_{V V}$ and $\mu_{H H}$ ), by using the set of six real values provided by the linear polarizations (i.e. real and imaginary parts of the coherences).

The solution of the model fitting has been implemented by means of the minimization of the global distance between model coherences and data, which has been carried out with a genetic algorithm named GENOCOP2 [Mic96], developed by Dr. Z. Michalewicz, and freely available at the web site www.coe.uncc.edu/ zbyszek/evol-systems.html.

Figures 5.27, 5.28 and 5.29 present the results obtained with the hybrid approach outlined in Section 5.2.4, using the corn sample described previously with both $0.25^{\circ}$ and $0.5^{\circ}$ baselines, whereas Figures 5.30, 5.31 and 5.32 show the results by using the same approach in case of rice sample with $0.5^{\circ}$ and $1^{\circ}$ baselines.

As expected, all solutions suffer from a high dependence upon the initial guess. Consequently, we have carried out 100 realizations of the inversion solution for each frequency, providing the algorithms with random initial values. Therefore, results presented here are plotted in form of mean values and standard deviations, thus providing quantitative measurements about the stability or robustness of the inversion.

Let us proceed to analyze the results for the maize sample. Firstly, it can be observed that the estimation of height is quite stable with frequency for both values of baseline, with a $10 \%$ accuracy for the vegetation layer and a $15 \%$ for topography, although for a $0.5^{\circ}$ baseline and above $6 \mathrm{GHz}$ the corresponding results are wrong due to the extreme volume decorrelation and they are not shown here. Note also that important differences appear for the estimates of extinction coefficients and the ground-to-volume ratios. On the one hand, the use of the shorter baselines provides average values of extinction coefficients in the expected range [UTS87, PSO5], although their standard deviations are high. It is important to mention that the qualitative behavior predicted by the scattering physics (i.e. the extinction for the vertical polarization is higher than for horizontal polarization, and they approach each other with an increase of the horizontal extinction as frequency increases) is fulfilled. Besides, note that the only experimental measurements of extinction of corn, found in the literature, give support to these results [UTS87]. The interpretation of the retrieved estimates of groundto-volume ratios is not evident, since many parameters contribute to their final values (see expression (4.72) in Chapter 4). In principle, it can be stated that their relative order agrees with the theoretical predictions, since the highest ground-to-volume ratio must correspond to the HH channel. In addition, the trends shown by the three channels follow the expected behavior, because the ground response is weaker when compared to the volume response as frequency increases. Moreover, as expected, $\mu_{V V}$ remains always below the other two channels, because of the weaker response from the ground-stem double bounce contribution.

On the other hand, when using the larger baseline, the extreme volume decorrelation above $6 \mathrm{GHz}$ makes the estimates to be meaningless. Anyway, below that frequency reasonable estimates for extinctions as well as ground-to-volume ratios are obtained.

Second, a similar analysis is performed on the rice sample estimates. Figures $5.30,5.31$ and 5.32 present the obtained estimates for the frequency range $5-9 \mathrm{GHz}$ with baselines of 
$0.5\left(k_{z}=0.52 \cdot f(\mathrm{GHz})\right)$ and 1 degree $\left.k_{z}=1.04 \cdot f(\mathrm{GHz})\right)$, respectively. The radar response from this target is dominated by the backscattering from the ground-stem interaction, which is helped by the flooded condition of the soil. This dominance produces two important effects. First, below $5 \mathrm{GHz}$ the backscatter response of the short vegetation volume is too weak, when compared to the ground-stem contribution, to produce any useful features in the PolInSAR observables and, as a result, to invert any parameter from them. Second, all coherences are very concentrated on the complex plane, forming a cluster close to the unit circumference.

The proximity to the unit circumference yields extremely accurate estimates of the ground position, since any fitted line crosses the true topographic phase $\phi_{0}$. Note that the interferometric phase of the ground-stem response is located exactly at the air-ground interface. This line fitting provides errors below $1 \mathrm{~cm}$ in the whole frequency range for the topography. The counterpart of the aforementioned disposal of the coherences is the reduced size of the visible region, which complicates the numerical inversion of the remaining six parameters. The estimation of vegetation height behaves well above $6 \mathrm{GHz}$. The average of the estimated values is closer to the true height $(75 \mathrm{~cm})$ for the 1 degree baseline and a $11 \%$ accuracy is obtained, but their variance is larger than for the short baseline. The interpretation of the retrieved extinctions is very difficult from the physical point of view. In our opinion, the estimates are so unstable due to two related causes: the low sensitivity of the direct model to extinction, already described in Section 5.2.1, and the low influence of extinction on the signal because of the short vegetation volume (only $75 \mathrm{~cm}$ ). Finally, the trend of the groundto-volume ratios agree with the observations made before for the maize target, but not their relative ordering. In the rice case, the flooded condition of the soil, which produces an extremely flat air-ground interface, reduces importantly the crosspolar contribution from the ground-stem interaction. As a result, the lowest ground-to-volume ratio is the crosspolar one. At the other extreme, as for the maize case, $\mu_{H H}$ is the highest. However, $\mu_{V V}$ it is very close to $\mu_{H H}$ at the highest frequencies, when the vegetation volume backscattering becomes significant.

\subsubsection{Inversion Results With a Dual-baseline Configuration}

The inversion problem has been also addressed by using a dual-baseline configuration (see block diagram in Fig. 5.33) in order to enlarge the observation space (see Section 5.2.4). Inversion results obtained with this approach for maize and rice samples are shown in Figures 5.34 and 5.35, respectively. Again, in the case of maize, baselines of $0.25^{\circ}$ and $0.5^{\circ}$ were used, whereas in the case of rice sample the baseline values were $0.5^{\circ}$ and $1^{\circ}$.

Results obtained for the maize sample are from 2 to a maximum frequency of $6 \mathrm{GHz}$, in order to avoid the volume decorrelation produced above $6 \mathrm{GHz}$ by the $0.5^{\circ}$ baseline. Ground topography and vegetation height are estimated quite precisely in the whole frequency range ( $9 \%$ and $8 \%$ accuracies, respectively), with a very high numerical stability. In contrast, extinction estimates fluctuate when the initial solution of the algorithm is changed (see the error bars). In addition, as in the results from the hybrid algorithm, vertical extinction is 
always higher than the horizontal one. Their difference ranges between 0.5 and $1 \mathrm{~dB} / \mathrm{m}$. Nevertheless, the standard deviation of estimates is not negligible. Finally, all ground-tovolume ratios decrease with frequency, as we expected from the stronger vegetation response at higher frequencies.

In Figure 5.35 the estimates of the dual-baseline approach applied to the rice data from 5 to $9 \mathrm{GHz}$ are shown. Note that frequencies below $5 \mathrm{GHz}$ are discarded because of a lack of sensitivity to the vertical structure of rice due to the short height as commented previously in Section 5.3.3, i.e. the direct backscattering from the stems and leaves is too weak when compared to the ground-stem interaction.

Once again, the ground position $z_{0}$ is retrieved with extremely good accuracy (i.e. $4 \%$ which corresponds to maximum absolute error below $1 \mathrm{~cm}$ ), as a result of the dominance of the ground-stem contribution, which is helped by the flooded condition of the soil. However, plants height is underestimated and it presents a higher variance than in the maize case. Note that in this case, due to the short vegetation volume, the visible region of the coherences is reduced to a small cluster and, hence, a greater ambiguity in the height estimation is produced.

Extinction estimates are less stable than in the maize experiment, and the average values of $\sigma_{V}$ and $\sigma_{H}$ do not approach each other at high frequencies. All ground-to-volume ratios are quite constant with frequency, and $\mu_{H V}$ is always the smallest due to its lowest ground-stem response because of the ground flatness, as explained before.

Retrieved values for the ground-to-volume ratios are different for the rice when obtained by the hybrid approach (see Fig. 5.32) and by the dual-baseline algorithm (see Fig. 5.35). More precisely, all $\mu$ estimates for the dual-baseline are lower than for the hybrid approach (note that the vertical scales are different). Their difference ranges from 20 to $5 \mathrm{~dB}$, depending on frequency and polarization channel. In addition, the estimated vegetation heights in Fig. 5.35 are mostly lower than with the hybrid approach. The slightly different performance of both techniques is a consequence of their working principle. As explained in the previous subsection, the first step in the hybrid approach provides a good approximation of the ground topography $z_{0}$, whose accuracy influences the rest of unknowns. With the dual-baseline algorithm, all seven parameters are estimated at the same time and none of them exhibits any preference. Consequently, the numerical minimization algorithm is more likely to fall in local minima with ground positions lower that the true one and, as explained, in these cases the rest of inverted parameters suffer the corresponding change: all $\mu$ 's move to lower values and $h_{v}$ is also smaller. We have observed this specific behavior in the detailed results, showing the presence of a number of solutions with these properties: lower values of $z_{0}, h_{v}$ and $\mu$ 's. Note that the error in these estimates of $z_{0}$ is about $2-5 \mathrm{~cm}$ below the true ground position. This small offset is enough to alter importantly the rest of parameters in the rice case because all coherences are very close to the unit circumference.

The presence of the mentioned shifted solutions within the whole set of solutions (obtained with different initializations) produces a decrease in the average estimation of ground-tovolume ratios and vegetation depth. A second consequence is an increase in the variability 
of the results, which is quite evident in the standard deviations of the ground-to-volume ratios.

Despite these drawbacks, note that the dual-baseline approach enables the estimation of the whole set of parameters simultaneously by means of a numerical optimization algorithm. In order to take advantage of such feature, i.e. no need to have coherence points well separated along the line, the adaptation of the current $\mathrm{OVOG}$ model to take into account a more realistic backscattering response, i.e. not exponential [Clo07], is mandatory.

Additionally, it must be pointed out that the dual-baseline approach deserves a deeper analysis in order to describe more precisely the impact of the baseline ratio in the inversion performance. As a first step, a number of simulations have been carried out as a function of baseline in order to explore the effect on the coherence loci. First observations show that the separation between the extreme lines (for the copolar channels) which define the region of coherences is not a monotonic function of the baseline, and reaches a zero angle for certain baselines. This feature is illustrated in Fig. 5.36, where difference of slopes between copolar lines is plotted as a function of baseline. According to this configuration, positive slope differences correspond to an inversion of the relative positions of extreme lines of the coherence region with respect to the ones predicted by the model physics (i.e. the line of the copolar channel with the highest extinction should be located closer to the origin). Zero slope difference values correspond to a collapse into a single line.

This variation of the width of the coherence region as a function of baseline, together with the increasing volume decorrelation for larger baselines, must be taken into account for inversion purposes. On the one hand, the coherence region at certain baseline should be wide enough to assure some sensitivity for extinction. On the other hand, a narrow region is useful for an accurate topography estimation, which is a key parameter affecting importantly the retrieval of the rest of parameters.

In order to summarize the inversion performance of the three retrieval procedures presented in this Chapter, a comparison of the accuracy values provided by each method for height and topography estimates is shown in Table 5.1. These values represent the worst case but, as shown in previous plots, even a 5-6\% accuracy can be reached for certain configurations in the maize sample and accuracies lower than $11 \%$ for the rice sample, but with a high variability.

Note that the inversion accuracy is similar for all three procedures, except for the height retrieval of the rice sample with the dual-baseline approach, where non acceptable estimation errors are obtained. Consequently, if we focus on vegetation depth and topography then the geometrical method should be chosen because of its implementation simplicity and low computational cost, compared to the hybrid methods. 


\begin{tabular}{|c|c|c|c|c|}
\hline ACCURACY & \multicolumn{2}{|c|}{ Corn } & \multicolumn{2}{c|}{ Rice } \\
\hline & $h_{v}$ & $z_{0}$ & $h_{v}$ & $z_{0}$ \\
\hline Geometrical & $11 \%$ & $11 \%$ & $11-13 \%$ & $4 \%$ \\
\hline Hybrid & $10 \%$ & $15 \%$ & $11 \%$ & $4 \%$ \\
\hline Dual-baseline & $9 \%$ & $8 \%$ & $>30 \%$ & $4 \%$ \\
\hline
\end{tabular}

Table 5.1: Comparison of the retrieval accuracy provided by each inversion procedure for height and topography.

\subsubsection{Requirements for Space-borne Systems}

This section is aimed to present some conclusions concerning the technical requirements in the design of an interferometric SAR system for agricultural crops monitoring. Note that an exhaustive analysis on this issue is beyond the scope of this thesis since it would require an additional chapter. Therefore, this topic remains as continuation of the work presented here.

Regarding the vertical wavenumber requirements commented in previous sections, it can be stated that the required range of baseline values of the InSAR system is not very restrictive. For example, with the ASAR sensor of the ENVISAT mission (with a satellite height of about $800 \mathrm{~km}$, an incidence angle of $23^{\circ}$ and $5.3 \mathrm{GHz}$ of center frequency), baselines from 150 to $1000 \mathrm{~m}$ provide vertical wavenumbers between 0.1 and 0.7 , which ensure low volume decorrelation and enough sensitivity to the vertical structure of the target. In the particular case of ASAR, however, one has to consider the effect of the wavenumber shift, because of the narrow frequency bandwidth of Envisat (18 MHz). Consequently, the critical baseline is $1253 \mathrm{~m}$ and the maximum practical baseline assuming half the available spectrum could be set to about $600 \mathrm{~m}$, with the corresponding maximum vertical wavenumber reduced to 0.4 . These values correspond to the monostatic case. Instead, in the bistastic case, the spectral shift would be halved and, hence, the critical baseline would increase up to about $2500 \mathrm{~m}$.

This constraint limits the applicability of the techniques proposed in this thesis for short vegetation, since relative high values of the vertical wavenumber are required in order to have enough sensitivity to the vertical structure. In the case of TerraSAR-X (dual-pol as operational mode and quad-pol as an experimental mode), with a $300 \mathrm{~m}$ baseline, the vertical wavenumber ranges from 0.34 to 0.70 when considering incidence angles of $45^{\circ}$ and $20^{\circ}$, respectively, which are the extreme values for the stripmap mode. A $150 \mathrm{MHz}$ nominal bandwidth will be employed for X-band (it allows up to $300 \mathrm{MHz}$ in other experimental mode). On the other hand, Radarsat- 2 , which provides fully polarimetric capability at Cband, will use a $100 \mathrm{MHz}$ bandwidth signal. These two systems will be also operated in a near future in tandem missions (TanDEM-X, already aproved, and Radarsat-3, respectively) in order to perform single-pass interferometric measurements of the Earth's surface. Hence, with these bandwidth values, a high vertical wavenumber can be provided avoiding baseline decorrelation and the results of this application are expected to be positive. 
It is possible to extent the discussion on the baseline geometry requirements taking as initial point the maize sample studied in this chapter. As stated in Section 5.3.2, the success of the retrieval procedure is limited at both sides by a extreme volume decorrelation, i.e. low coherence values, and by volume sensitivity. As shown before for the $1.8 \mathrm{~m}$ high maize sample, the inversion algorithm produce correct estimates even with a coherence of 0.3 at $5.3 \mathrm{GHz}$ for a $0.5^{\circ}$ baseline. This corresponds to a vertical wavenumber of 2.74 . On the other hand, a lower bound on the wavenumber is set to 0.52 , which happens at $2 \mathrm{GHz}$ and for a $0.25^{\circ}$ baseline. This configuration yields a 0.95 coherence. Here it is important to note that no univocal relationship exists between high coherence and volume sensitivity. This maximum coherence value is only provided for the sake of completeness and to give more information about the particular case used to illustrate the issue of the sensitivity of the interferometer to a vertically distributed scatterer, that is to say, a configuration with $0.25^{\circ}$ baseline at $2 \mathrm{GHz}$ yields a 0.52 wavenumber, which is the limit for the system to be sensitive enough to the volume.

Assuming these experimental values as limits for a correct parameter retrieval and considering a $45^{\circ}$ incidence angle and an orbit with a height of $550 \mathrm{Km}$, the required normal baseline to wavelength ratio as a function of height can be obtained. Figure 5.37 illustrates two realizations of this function. The dotted line is obtained by considering the minimum experimental coherence, i.e. 0.3, for a successful retrieval, whereas the solid line corresponds to a lower baseline limit related to the volume sensitivity. Both curves represent the upper and lower bounds of the normal baseline to wavelength ratio and, consequently, the design of the interferometer is constrained by the ratio $B_{n} / \lambda$ which must be contained inside the region plotted in Figure 5.37.

Although the normal baseline to wavelength ratio synthesizes the information for the design of the interferometer, it is also convenient to show the normal baseline requirement as a function of frequency for a given volume height. From the ratio $B_{n} / \lambda$ and considering the specific case of a $1.8 \mathrm{~m}$ high vegetation, two corresponding curves are obtained. In Figure 5.38 the dotted curve represents the maximum normal baseline for each frequency in order to avoid extreme low coherences whereas the solid line represents the minimum normal baseline which ensures enough volume sensitivity. Additionally, lines with points correspond to the critical normal baseline for different bandwidth values. As is observed, the constraint of minimum coherence is not restrictive at all since it corresponds to very high normal baselines or even non-realistic values. On the other hand, the lower bound (volume sensitivity) restricts the minimum baseline to $1700 \mathrm{~m}$ for $\mathrm{S}$-band, $1300 \mathrm{~m}$ for Cband and about $700 \mathrm{~m}$ for X-band. Furthermore, it is seen that the critical baseline is not a limiting factor for systems with a signal bandwidth greater that $40 \mathrm{MHz}$. Assuming this signal bandwidth and the same parameters than in Figure 5.37, the corresponding values of critical baseline for S, C and X-band and a monostatic interferometer are very high values (12400, 5870 and $3240 \mathrm{~m}$, respectively). This is even more evident in a bistatic case, since the spectral shift is half the monostatic case and, hence, the critical baseline doubles.

Nevertheless, note that even for baselines less than critical problems could arise depending on the application. For example, range spectral filtering is commonly applied to avoid problems by wavenumber shift but this entails a broadening in range resolution and hence a 
decrease in the available number of looks, which could be an important problem for agricultural monitoring in small areas.

These results give an insight into the interferometer requirements but their generalization is not straightforward since, as mentioned previously, they are based on experimental observations on a specific maize sample with $1.8 \mathrm{~m}$.

Temporal decorrelation effect is a limiting factor specially important in crop monitoring applications. This decorrelation source will be always present in repeat-pass systems and, hence, this will reduce the performance in the estimation process. This could be a disadvantage for PALSAR/ALOS sensor and future BIOMASS mission [soBmBmmfCA]. Recently, PALSAR/ALOS sensor whose aim is forest-grassland discrimination and land cover classification, started to provide L-band data [MPSW07]. Nevertheless, its long revisit time (46 days) reduces its applicability for crop monitoring by means of PolInSAR-based techniques, since the growth cycle may span from 1 to 3 months, depending on the crop type. In a near future the BIOMASS mission will focus on producing global scale high-resolution maps of above-ground biomass in order to quantify the role of terrestrial systems in the carbon cycle. This system will operate at P-band with a $6 \mathrm{MHz}$ signal bandwidth and a 25 days repeat cycle. The reduced bandwidth will limit the performance by critical baseline issues and will produce a low resolution $(50-100 \mathrm{~m})$, while the relative long revisit time for agricultural monitoring applications will induce also high temporal decorrelation.

\subsection{Conclusions}

The existing two-layer model [TSO0] for forest height estimation has been adapted for agricultural crops in order to develop a retrieval algorithm based on polarimetric SAR interferometry. The proposed inversion scheme was specifically tailored for vertically oriented agricultural plants over a ground surface, with extinction coefficients dependent on the wave polarization. The formulation of the model (OVoG) and the principles and limitations of the inversion scheme were outlined.

The fidelity of the direct model used for the OVoG case has been investigated by comparing the region of possible coherences provided by the theoretical formulation and the zone occupied by all the possible combinations of polarizations derived from the experimental data. Actually, the expected matching of these two regions is not completely fulfilled, so this limitation may result in wrong estimates of the physical parameters.

Discrepancies between the model predictions and the experimental data arise as a consequence of several assumptions which make the model very simple. Firstly, the vegetation layer is assumed to be homogeneous, and it is not true. Secondly, the interaction among the vegetation elements has been taken into account only partially by means of a statistical modeling of the total first order backscattering response of the medium. However, it has been demonstrated [TDZKOO, MLMO3] that multiple scattering should be considered for such targets. 
An analysis of possible strategies to solve the inversion problem for the OVoG model has been carried out. The nonlinearity of the problem (similarly to the RVoG case) makes necessary the use of numerical methods in order to calculate the crop and ground heights, the extinction coefficients and the ground-to-volume ratios. In addition, the problem becomes indeterminate since in the common case of single-baseline systems there exist six observables and seven unkowns. Hence, three retrieval procedures have been proposed and tested.

All proposed inversion schemes were tested experimentally with indoor wide-band polarimetric measurements on samples of corn and rice fields. Compared to the ground truth, results show that the estimates of the thickness of the vegetation layer are reasonably accurate for a wide range of configurations (frequencies and baselines). The range of validity is limited at one extreme by the volume decorrelation, produced by large baselines and high frequencies. This constrains the $k_{z} \cdot h_{v}$ product to an upper bound of about 5.6 for the case of maize crops. At the other extreme, there is a minimum value of baseline and frequency, i.e. a minimum for the $k_{z} \cdot h_{v}$ product which provides enough sensitivity to the vertical structure of the target. In the case of a shorter crop such as rice, this value is about 2.5 . The algorithm performs well only when the coherence is above 0.3 . Below this minimum value, which also depends on the height and density of the target, the inversion procedure does not yield correct estimates.

In the first approach, the physical parameters of the agricultural crop are retrieved through a technique based on a linear fitting of the measured coherences on the complex plane, similarly to the original inversion technique for forests [ $\mathrm{CP} 03]$. In this case, the retrieval algorithm provides right estimates of the ground vertical position and the crop height, but not the extinction coefficients, which are assumed a priori to be in a certain range.

Second, an hybrid approach has been proposed and tested. This method consists of two steps: geometrical and numerical. The first one corresponds to the line fitting procedure mentioned previously, which provides an estimate of the topographic phase. The second step, that makes use of the estimated ground phase, is a genetic algorithm that yields solutions for the rest of parameters. The performance of this algorithm is strongly dependent on the initial values, and a high number of tests must be performed. Two different behaviors can be observed depending upon the kind of vegetation. On the one hand, reasonable estimates of volume height, extinction coefficients and ground-to-volume ratios are retrieved in a wide frequency range for various baseline configurations for the maize sample. On the other hand, in the case of the rice sample, only accurate estimates of topographic phase are obtained due to the dominant ground-stem contribution. The retrieved volume height suffers either from a high variability on the average value for the smaller baseline or on a high standard deviation for the larger baseline. Besides, the extinction coefficients are in a clear disagreement with the expectations, since in both cases the differential extinction tends to increase as frequency increases. The ground-to-volume ratios evolve roughly as stated by the model predictions, but no definitive conclusions can be provided because of the complex nature of this parameter.

Third, a dual-baseline configuration was used in order to enlarge the observation space. In this case, 2 different values for the baseline were used, which produces 12 input real data 
available to estimate 7 model unknowns. The solution of the model fitting has been implemented with a genetic algorithm as well. The dual-baseline approach has shown slightly worse estimates in the rice case, since it suffers more importantly the influence of the initial solution values in the numerical minimization, whereas the hybrid approach is most robust due to a better estimation of ground topography. Further research, based on numerical simulations, must be carried out in order to show the impact of the baseline ratio in the inversion performance.

In summary, all three inversion approaches provide similar and reasonable estimates of vegetation height and an accurate retrieval of the ground vertical position (topography) at a wide frequency range. The height retrieval is slightly more accurate for the maize sample, whereas a more precise underlying topography estimation is feasible for the rice sample since it is based on the presence of a strong backscattering from the ground-stem interaction in at least one polarization. Note that this is accomplished in the rice sample case due to the short vegetation volume.

Due to the similar inversion performance for vegetation height and topography of all three procedures, the use of the geometrical method would be preferable since it is much simpler to implement and it requires a low computational cost compared to the hybrid methods.

With regard to the extinction coefficients, it is observed that the hybrid approach provides expected average values of extinction coefficients for the maize sample, although their standard deviations are high. Furthermore, it is important to mention that the qualitative behavior predicted by the electromagnetic theory (i.e. the vertical extinction coefficient is higher at $\mathrm{S}$-band, but at $\mathrm{C}$ and $\mathrm{X}$-band slightly decreases and becomes similar to the horizontal extinction coefficient, which is also higher than at $S$-band) has been observed. Nevertheless, this is not the measured behavior for the estimates of rice sample or by using the dual-baseline configuration.

The analysis of the retrieved estimates of ground-to-volume ratios does not provide any definitive conclusion since their interpretation is not evident due to the amount of parameters that contribute to their final values (see expression (4.43) in Chapter 4).

Finally, the analysis of inversion results with dual-polarization systems has been also addressed by applying the first approach. Results using the $\mathrm{HH}+\mathrm{VV}$ and $\mathrm{HH}-\mathrm{VV}$ polarization combinations have shown to be reasonably accurate compared to the full-polarimetric ones. This is an important result for the definition of new and future SAR missions, in order to profit from the capability of a coherent combination of copolar channels (e.g. TerraSAR$\mathrm{X}$, PALSAR/ALOS, Radarsat-2, TanDEM-X) and, additionally, it highlights the potential of compact polarimetry, which can take benefit from the fully polarimetric system without its limitations regarding the reduction of the swath width and the need of a higher bandwidth. 


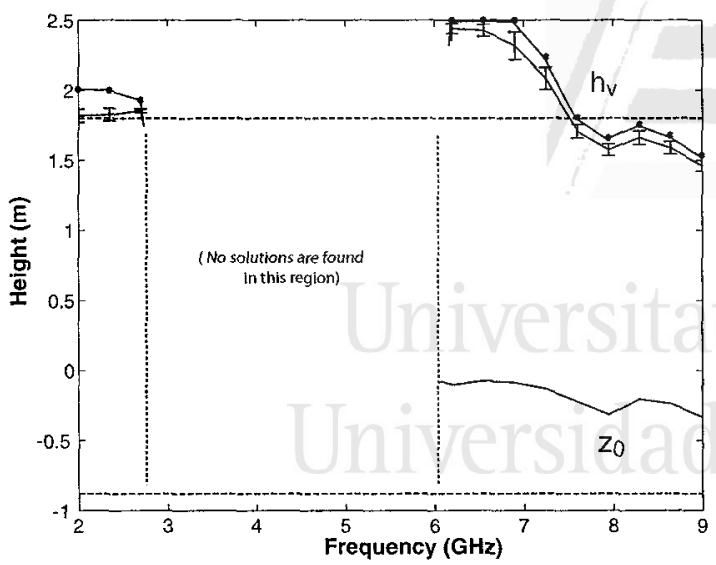

(a)

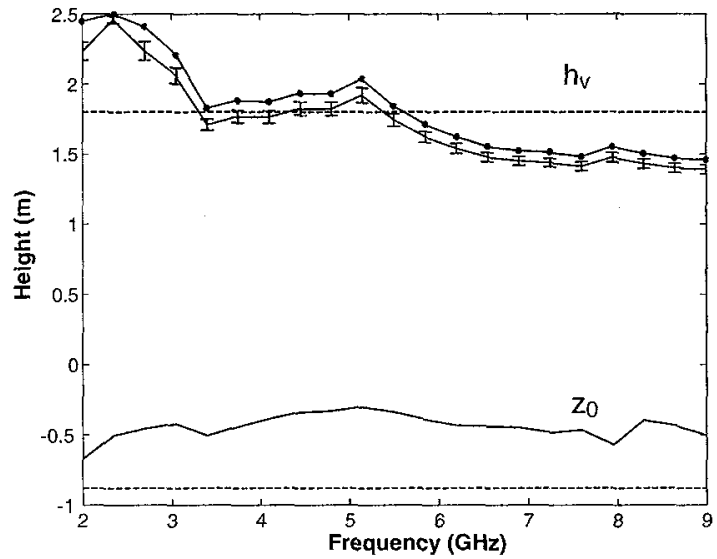

(b)

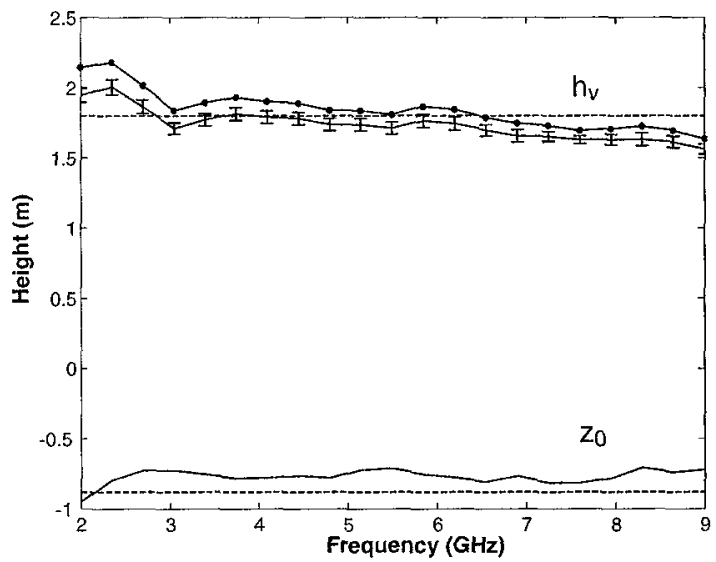

(c)

Figure 5.25: Retrieval results for the maize sample as a function of frequency. $B=0.25^{\circ}, k_{z}=$ $0.26 \cdot f(\mathrm{GHz})$. (a) Coherence points for $\mathrm{HH}$ and HV channels. (b) Coherence points for VV and HV channels. (c) Coherence points for HH+VV and HH-VV channels. Solid line with circles: standard RVoG estimates $(\sigma=0 \mathrm{~dB} / \mathrm{m})$. Solid line with error bars: mean and standard deviation of the set of possible solutions. Dashed line: true value. 


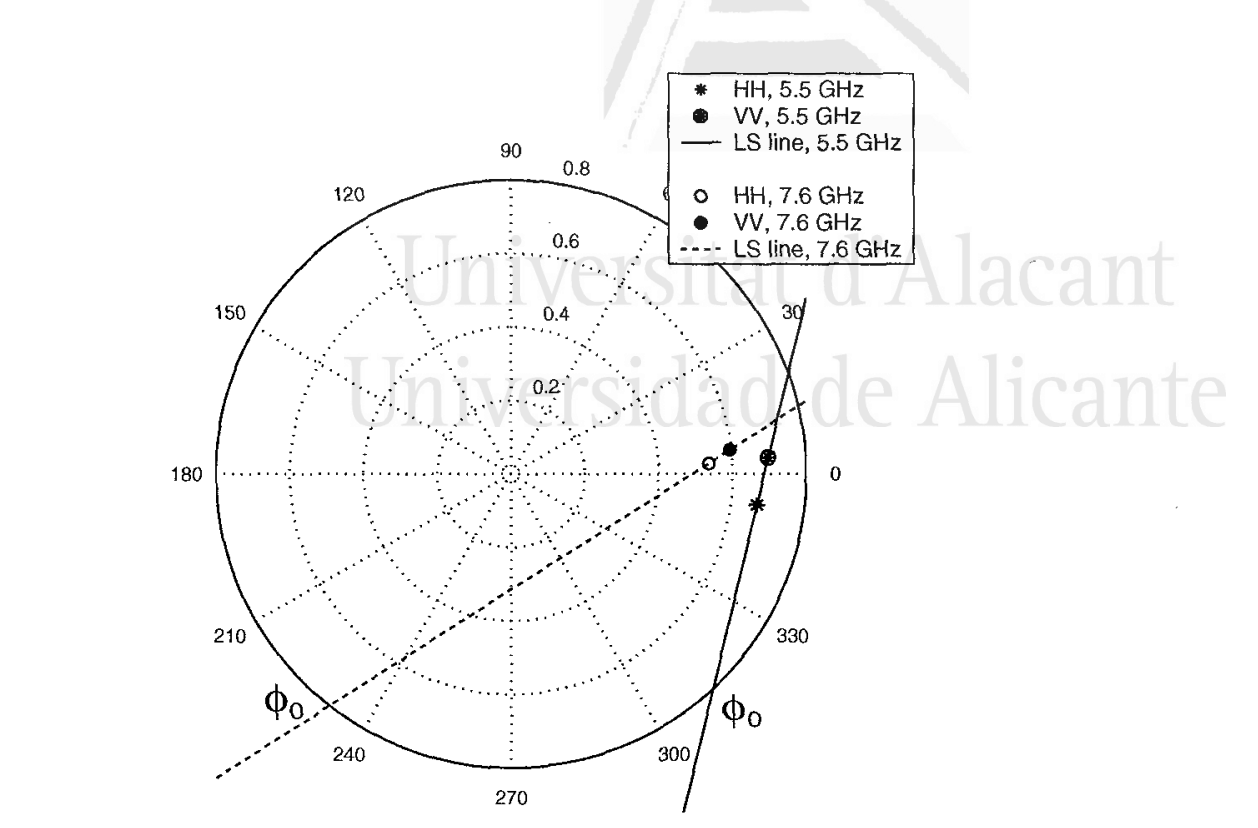

Figure 5.26: Estimation procedure for the maize sample $\left(\mathrm{B}=0.25^{\circ}\right)$ at $5.5 \mathrm{GHz}$ and $7.6 \mathrm{GHz}$ by only
using the copolar channels. When only two coherence values are considered a slight difference on
the location of those complex values can produce wrong estimates, since the fitted line can take any
orientation.

Figure 5.26: Estimation procedure for the maize sample $\left(\mathrm{B}=0.25^{\circ}\right)$ at $5.5 \mathrm{GHz}$ and $7.6 \mathrm{GHz}$ by only
using the copolar channels. When only two coherence values are considered a slight difference on
the location of those complex values can produce wrong estimates, since the fitted line can take any
orientation.

Figure 5.26: Estimation procedure for the maize sample $\left(\mathrm{B}=0.25^{\circ}\right)$ at $5.5 \mathrm{GHz}$ and $7.6 \mathrm{GHz}$ by only
using the copolar channels. When only two coherence values are considered a slight difference on
the location of those complex values can produce wrong estimates, since the fitted line can take any
orientation.

Figure 5.26: Estimation procedure for the maize sample $\left(B=0.25^{\circ}\right)$ at $5.5 \mathrm{GHz}$ and $7.6 \mathrm{GHz}$ by only
using the copolar channels. When only two coherence values are considered a slight difference on
the location of those complex values can produce wrong estimates, since the fitted line can take any
orientation.
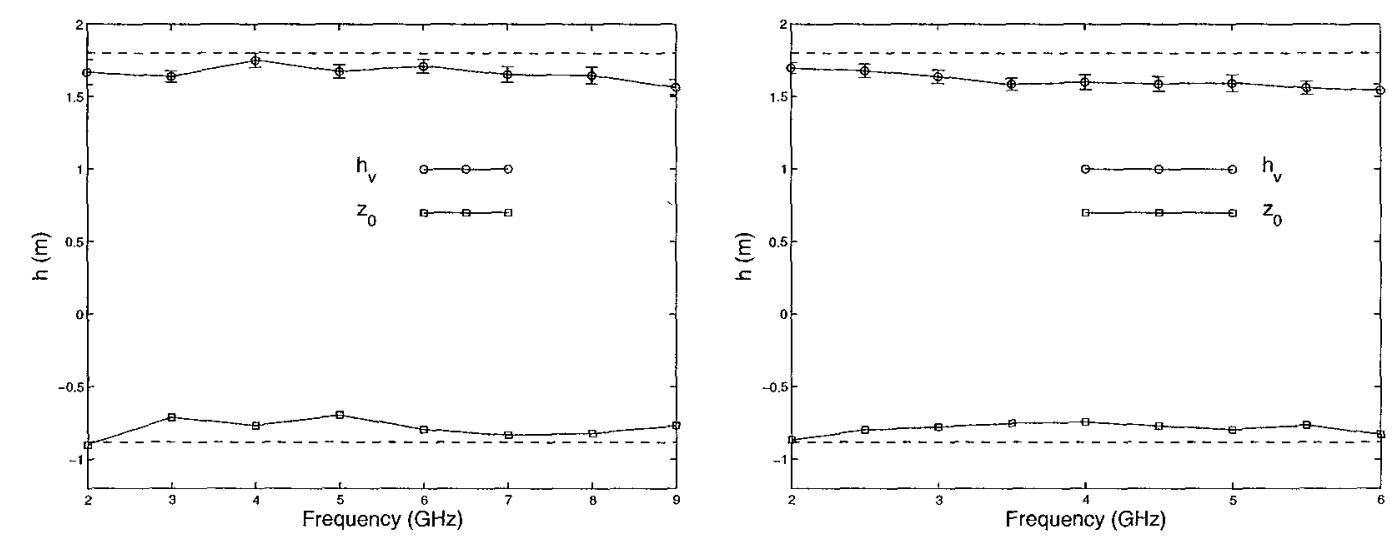

Figure 5.27: Height estimates with the hybrid approach for the corn sample as a function of frequency. a) $\left.B=0.25^{\circ}, k_{z}=0.26 \cdot f(\mathrm{GHz}) ; \mathrm{b}\right) B=0.5^{\circ}, k_{z}=0.52 \cdot f(\mathrm{GHz})$. 

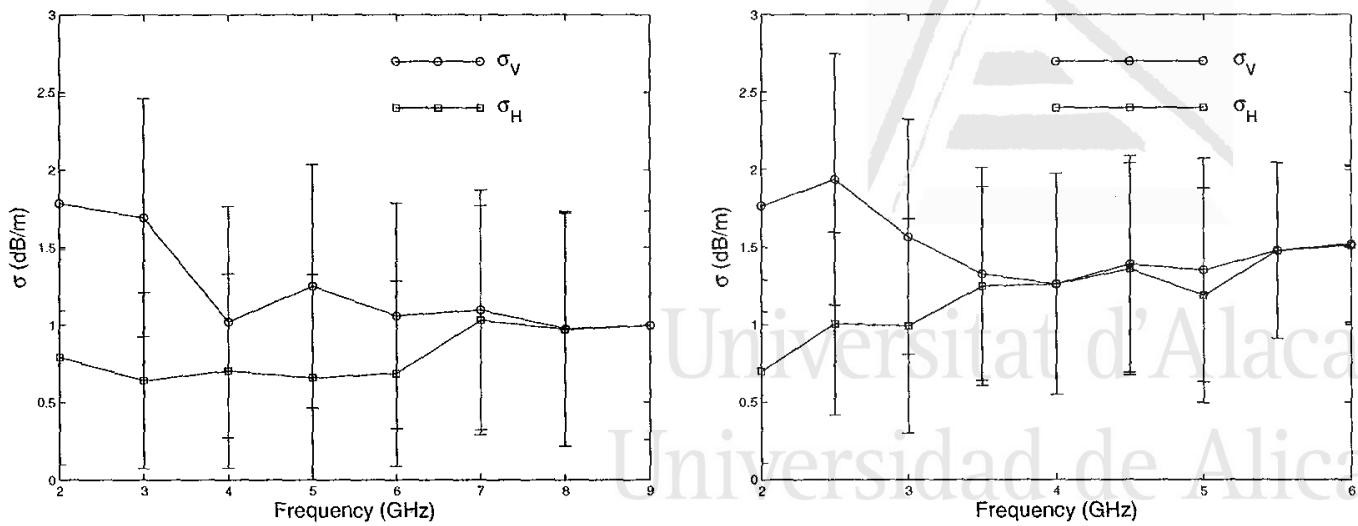

Figure 5.28: Extinction coefficients estimates with the hybrid approach for the corn sample as a function of frequency. a) $B=0.25^{\circ}, k_{z}=0.26 \cdot f(\mathrm{GHz}) ;$ b) $B=0.5^{\circ}, k_{z}=0.52 \cdot f(\mathrm{GHz})$.
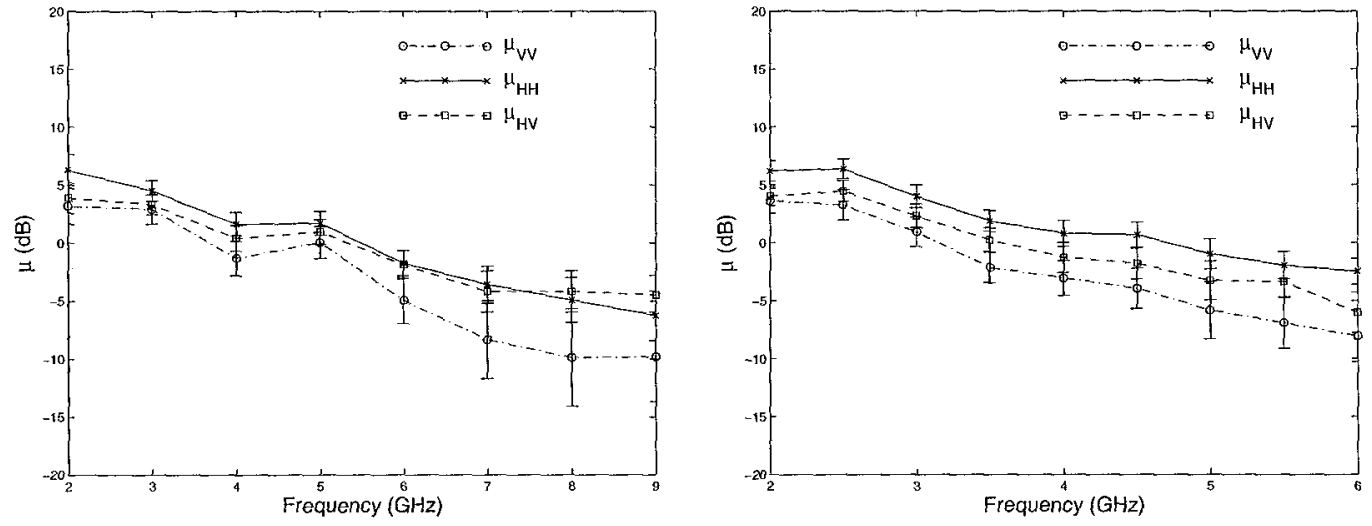

Figure 5.29: Ground-to-volume estimates with the hybrid approach for the corn sample as a function of frequency. a) $B=0.25^{\circ}, k_{z}=0.26 \cdot f(\mathrm{GHz})$; b) $B=0.5^{\circ}, k_{z}=0.52 \cdot f(\mathrm{GHz})$.
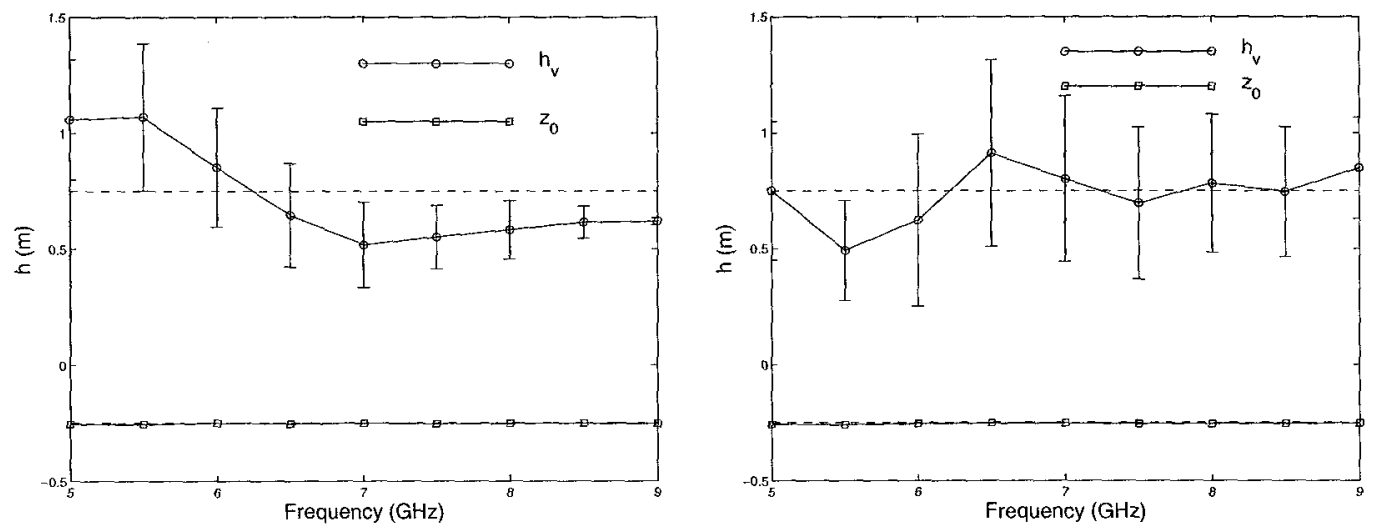

Figure 5.30: Height estimates with the hybrid approach for the rice sample as a function of frequency. a) $B=0.5^{\circ}, k_{z}=0.52 \cdot f(\mathrm{GHz})$; b) $B=1^{\circ}, k_{z}=1.04 \cdot f(\mathrm{GHz})$. 

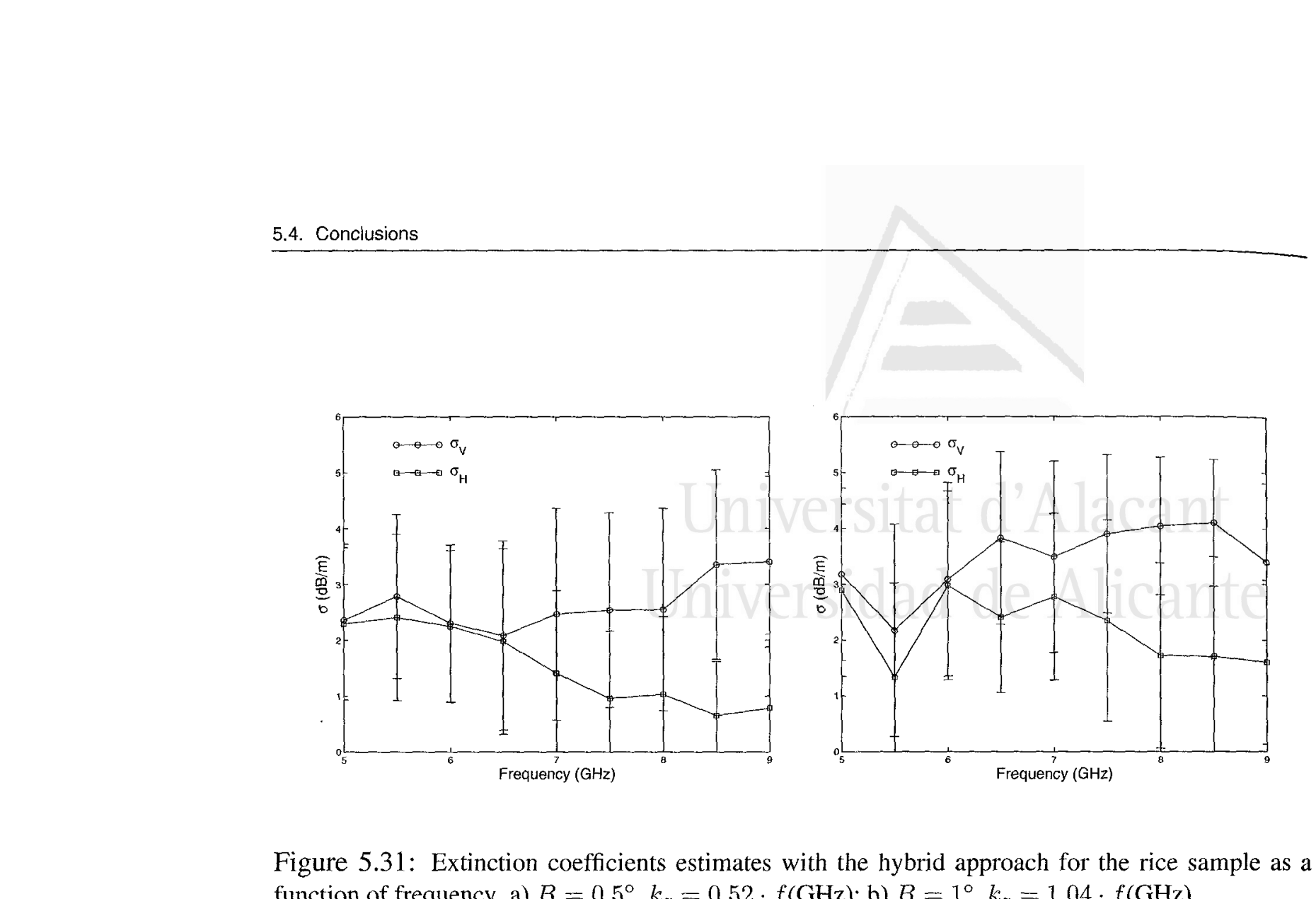

Figure $5.31:$ Extinction coefficients estimates with the hybrid approach for the rice sample as a

Figure $5.31:$ Extinction coefficients estimates
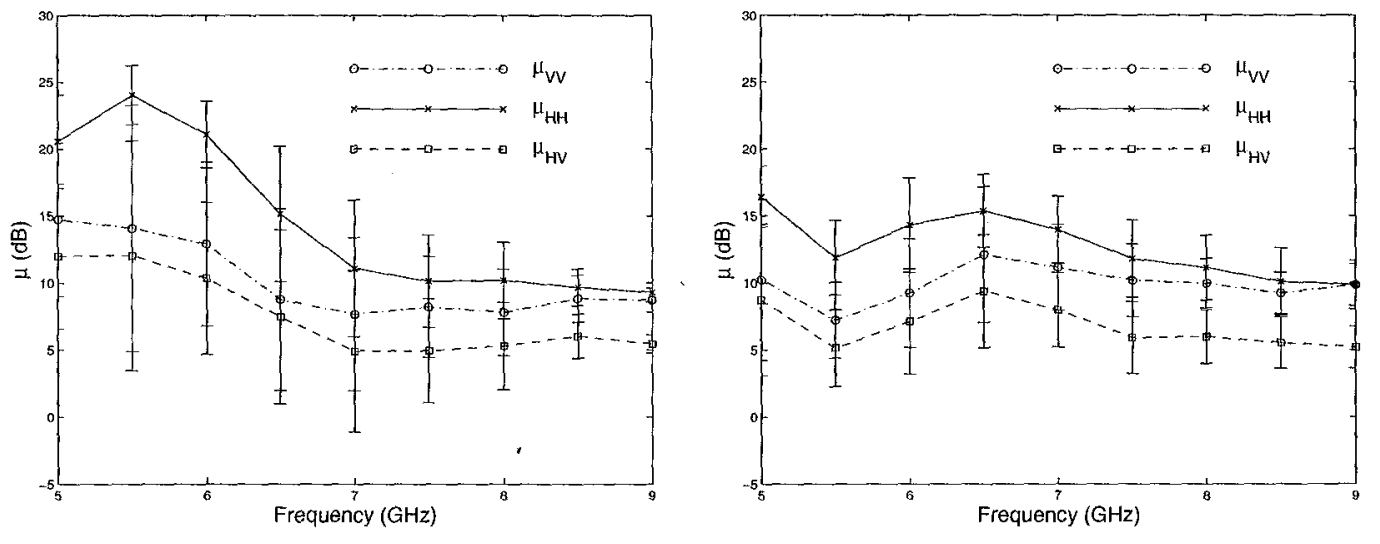

Figure 5.32: Ground-to-volume estimates with the hybrid approach for the rice sample as a function of frequency. a) $B=0.5^{\circ}, k_{z}=0.52 \cdot f(\mathrm{GHz})$; b) $B=1^{\circ}, k_{z}=1.04 \cdot f(\mathrm{GHz})$.

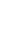

Tesis doctoral de la Universidad de Alicante. Tesi doctoral de la Universitat d'Alacant. 2007.

\author{
(1)
}




\section{Observables}

\section{Bascline 1}

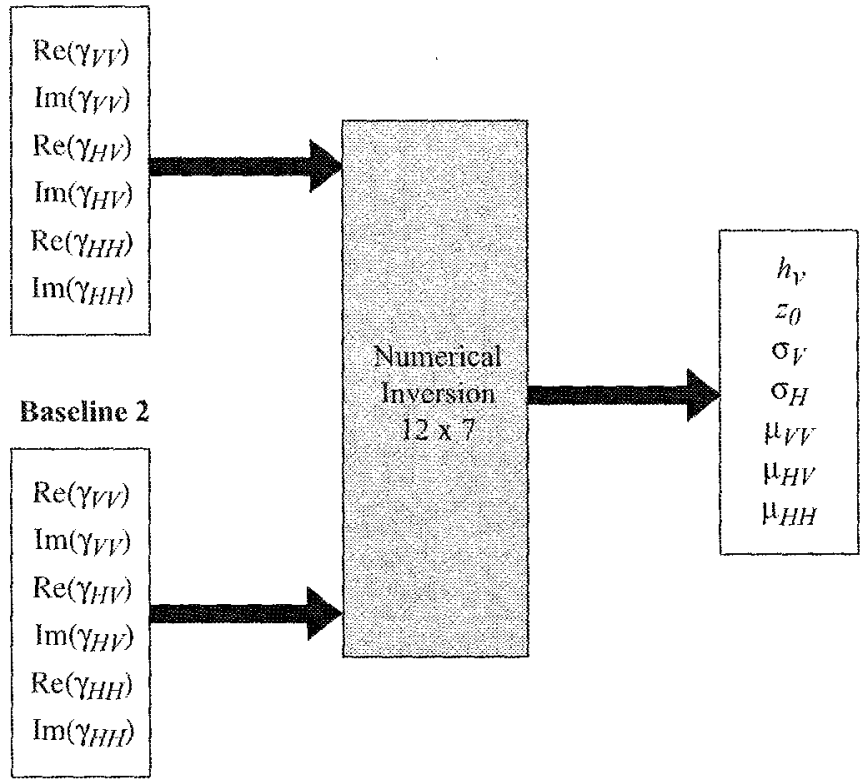

Figure 5.33: Block diagram of inversion algorithm with dual-baseline data. 


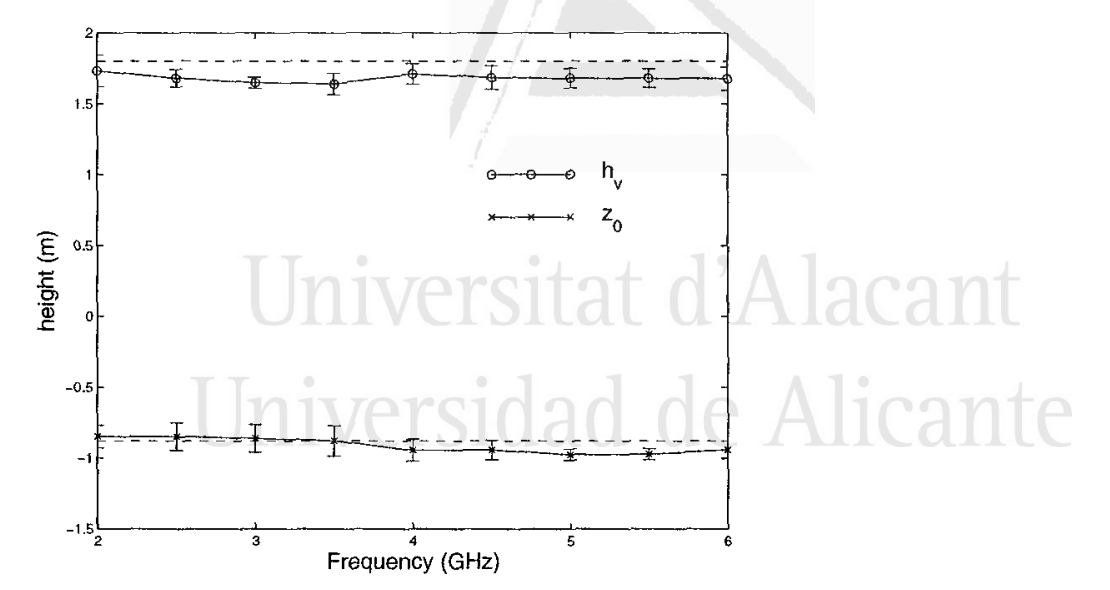

(a)

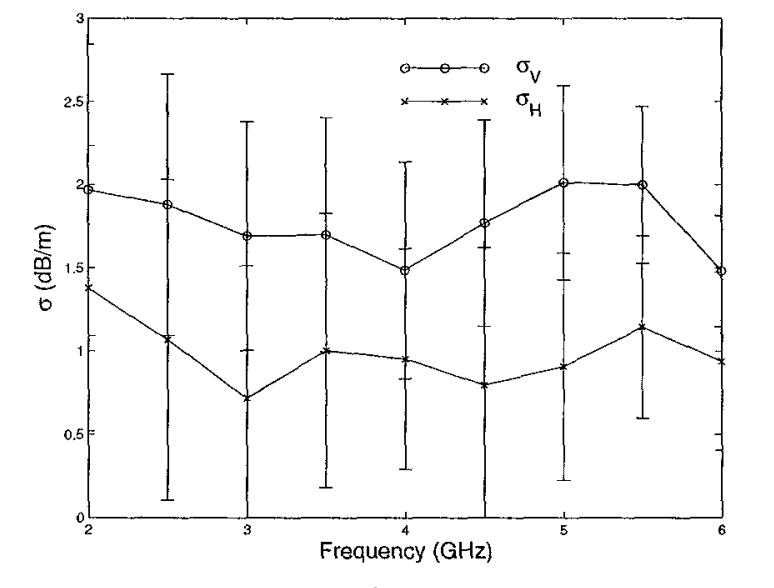

(b)

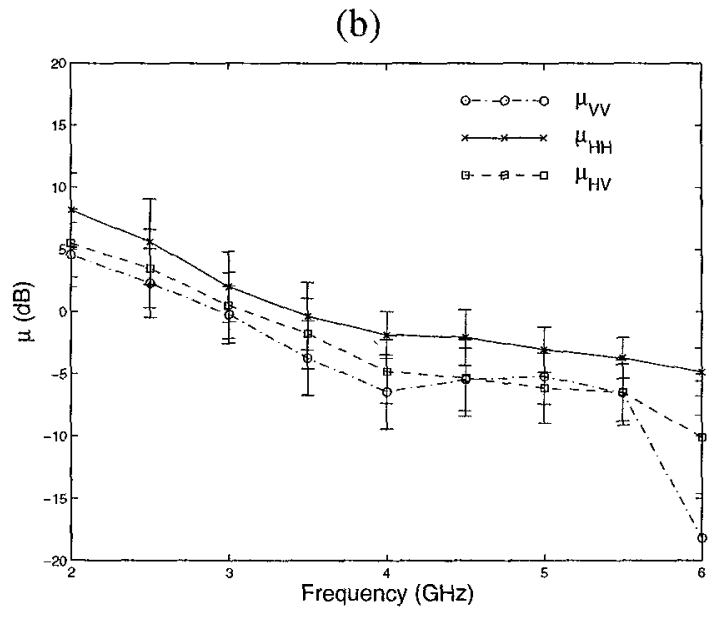

(c)

Figure 5.34: Inversion results with dual-baseline for the maize sample (2-6 GHz). $B=0.25^{\circ}$ $\begin{array}{ll}\text { and } 0.5^{\circ} . & \text { (a) Ground topography and } \\ \text { estimates. (c) Ground-to-volume ratio estimates. }\end{array}$

(a) Ground topography and volume height estimates. (b) Extinction coefficients
(2-6 GHz). $B=0.25^{\circ}$
(a)-to-volume ratio estimates. and $0.5^{\circ}$. (a) Ground topography and vol
estimates. (c) Ground-to-volume ratio estimates.
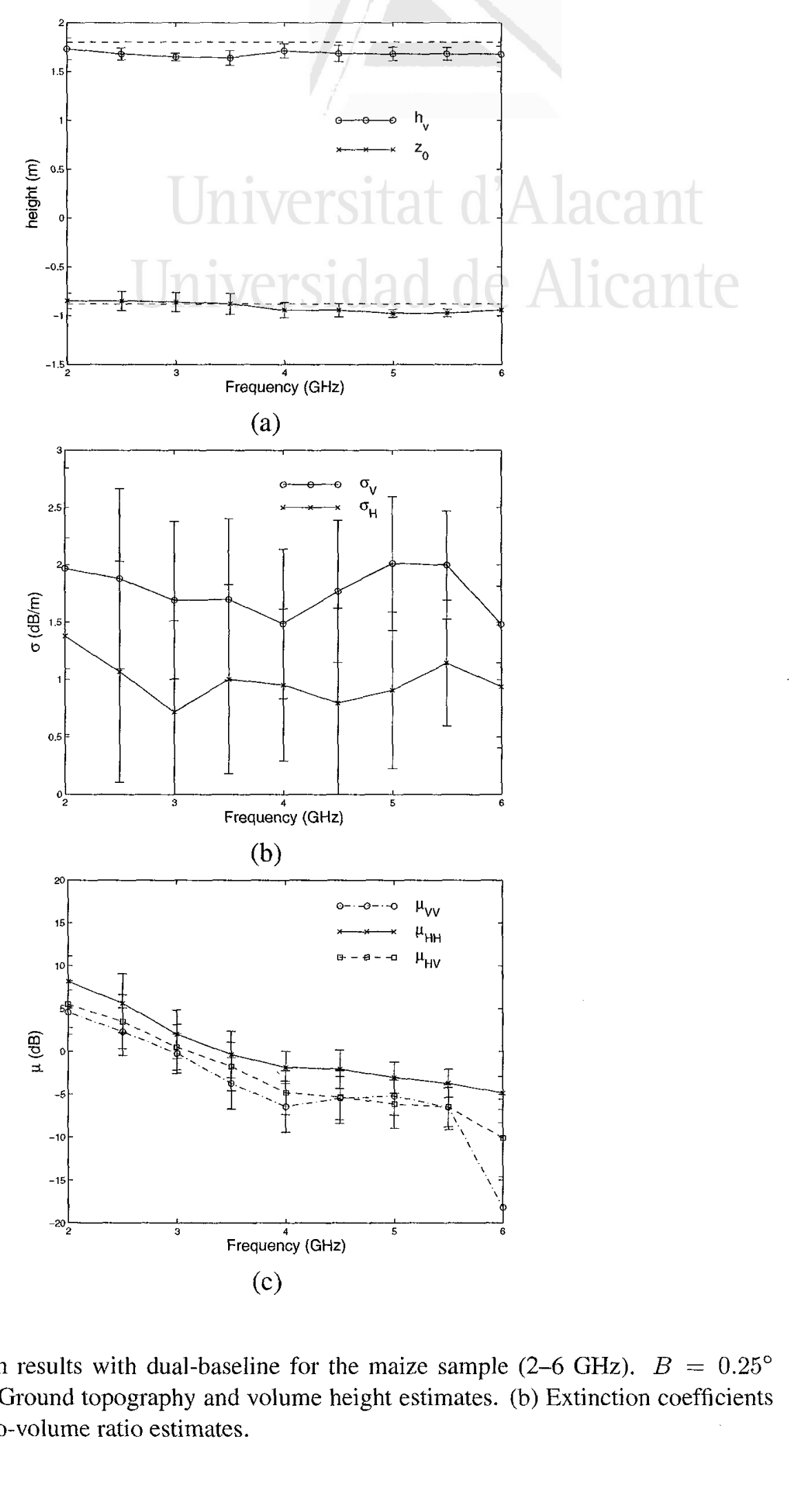

\author{
(1)
}

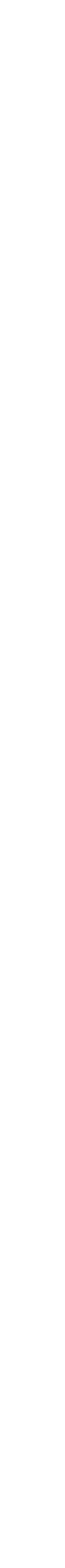




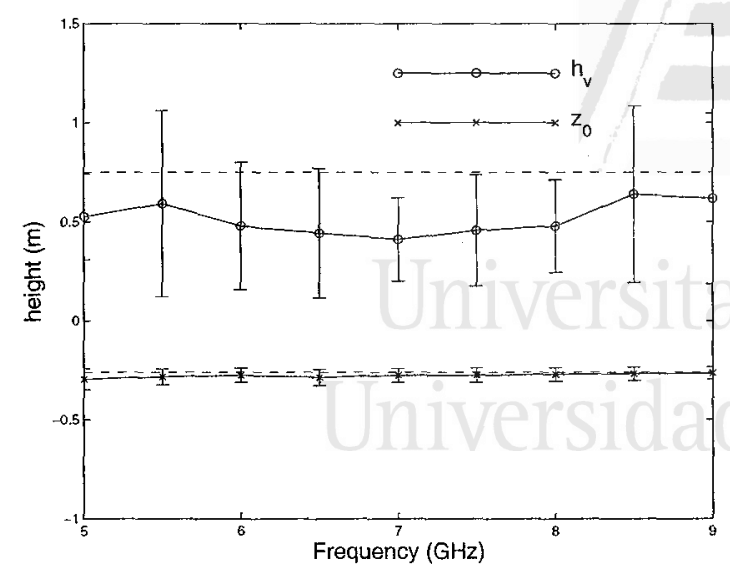

(a)

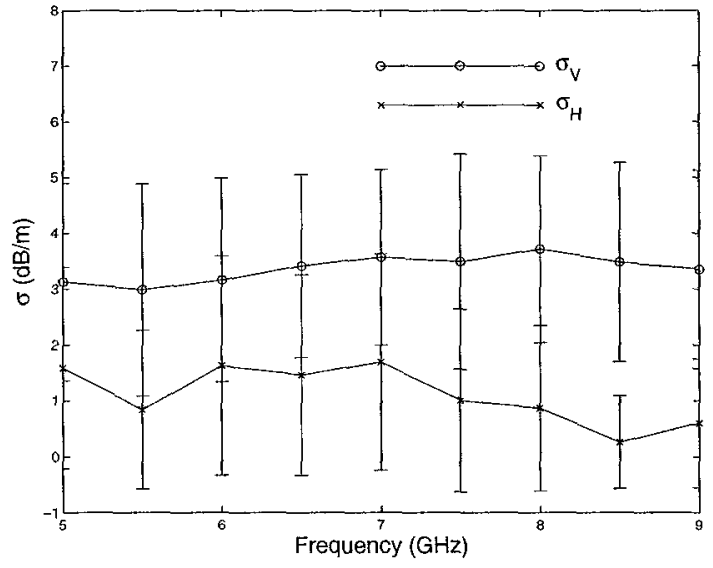

(b)

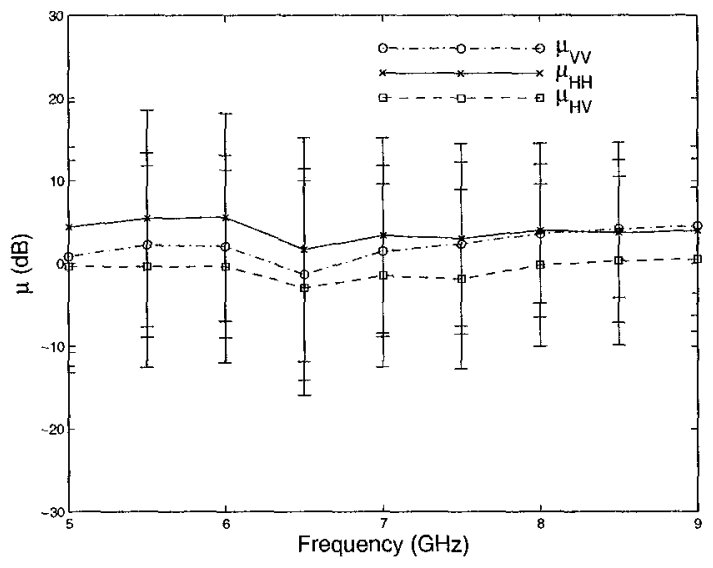

(c)

Figure 5.35: Inversion results with dual-baseline for the rice sample $(5-9 \mathrm{GHz}) . \quad B=0.5^{\circ}$ and $1^{\circ}$. (a) Ground topography and volume height estimates. (b) Extinction coefficients estimates. (c) Ground-to-volume ratio estimates. 


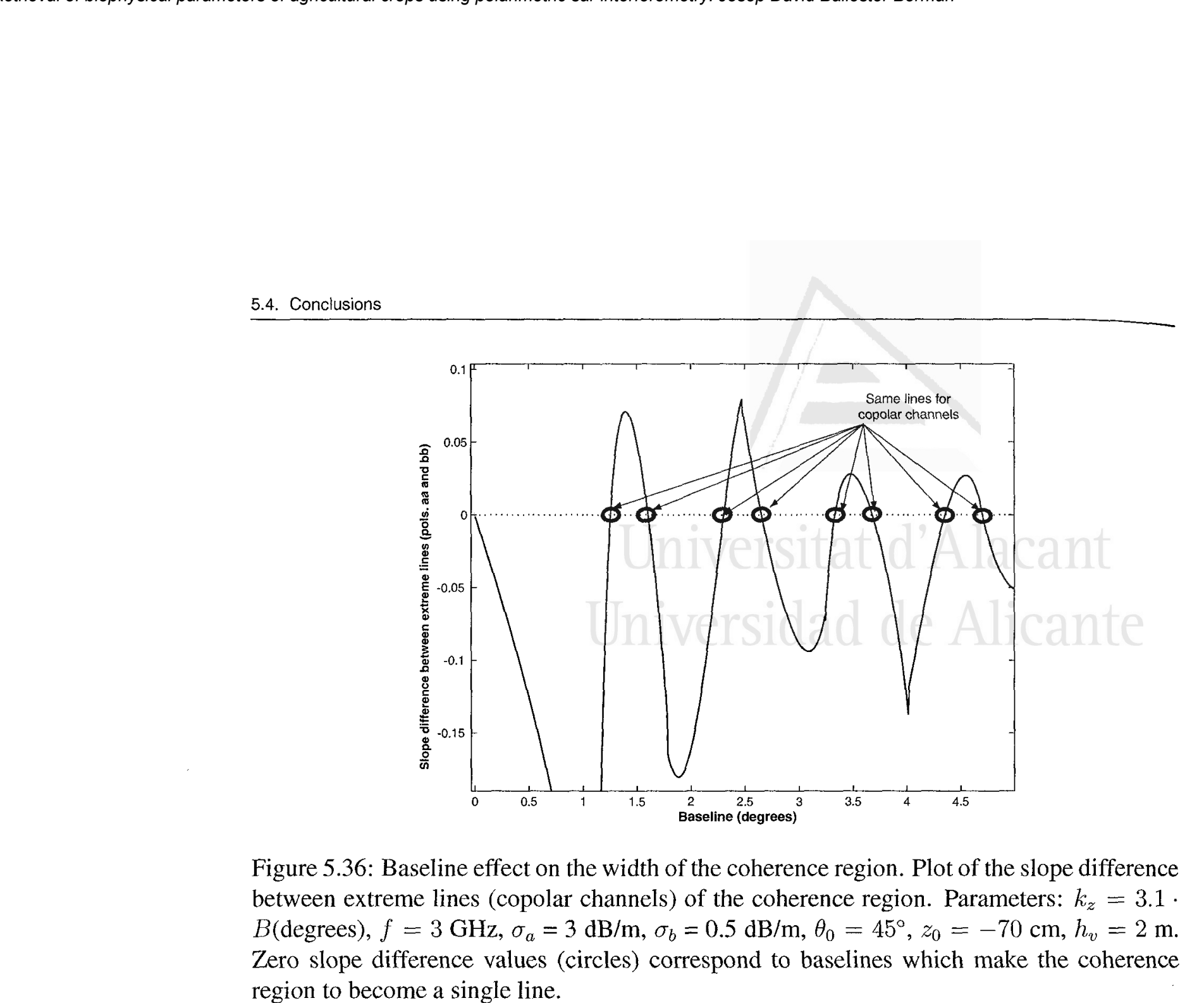

Figure 5.36: Baseline effect on the width of the coherence region. Plot of the slope difference between extreme lines (copolar channels) of the coherence region. Parameters: $k_{z}=3.1$. $B$ (degrees), $f=3 \mathrm{GHz}, \sigma_{a}=3 \mathrm{~dB} / \mathrm{m}, \sigma_{b}=0.5 \mathrm{~dB} / \mathrm{m}, \theta_{0}=45^{\circ}, z_{0}=-70 \mathrm{~cm}, h_{v}=2 \mathrm{~m}$. Zero slope difference values (circles) correspond to baselines which make the coherence region to become a single line.

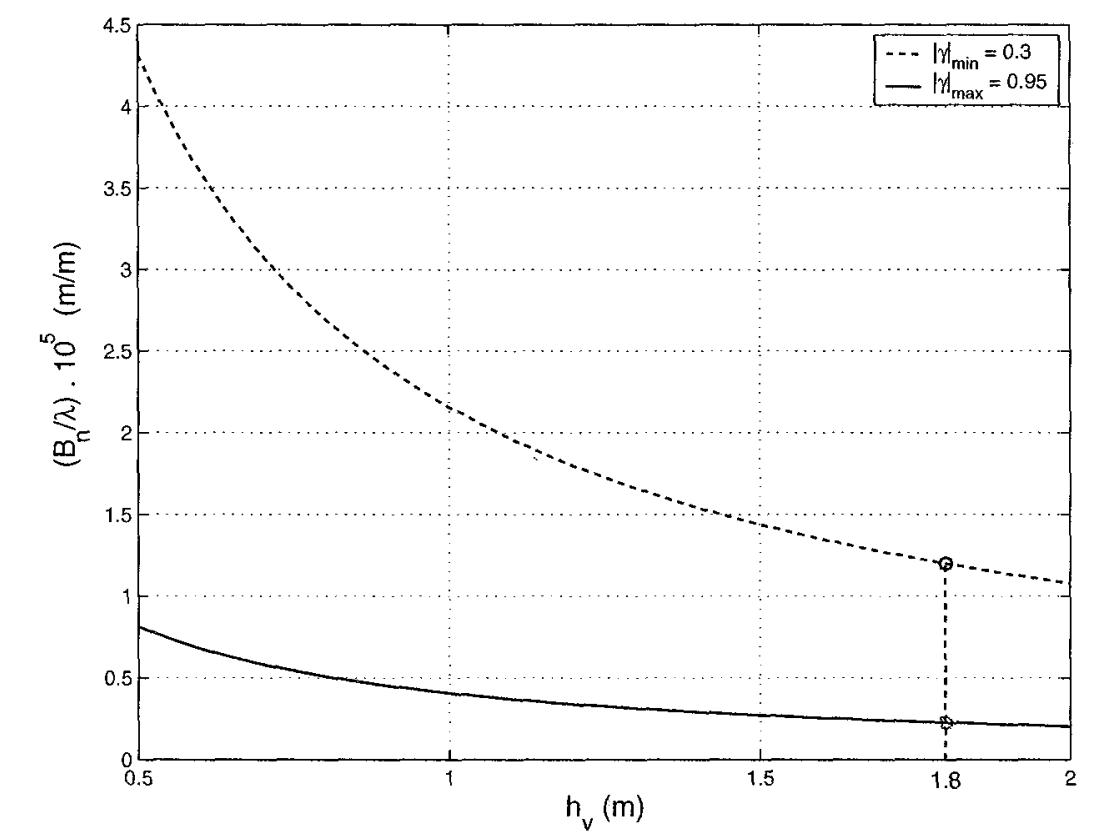

Figure 5.37: Normal baseline to wavelength ratio as a function of volume height. Dotted and solid lines correspond to 2.74 and 0.52 wavenumbers, respectively, obtained from the maize sample. Parameters: $h_{v}=1.8 \mathrm{~m}, \theta_{0}=45^{\circ}, H=550 \mathrm{Km}$.

(1) . 西

Tesis doctoral de la Universidad de Alicante. Tesi doctoral de la Universitat d'Alacant. 2007.

(3)

(1)

(1)




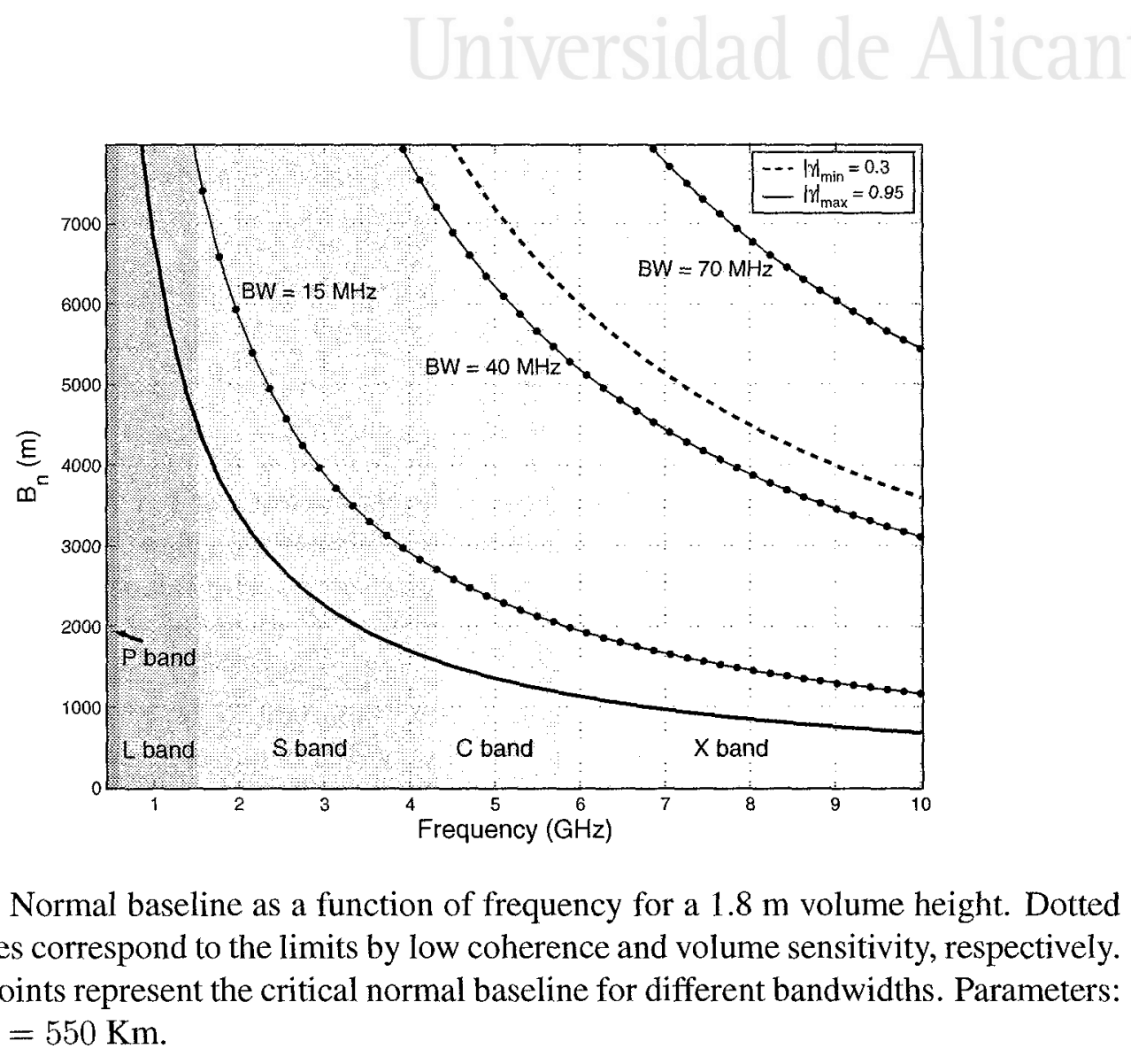

Figure 5.38: Normal baseline as a function of frequency for a $1.8 \mathrm{~m}$ volume height. Dotted and solid lines correspond to the limits by low coherence and volume sensitivity, respectively. Lines with points represent the critical normal baseline for different bandwidths. Parameters: $\theta_{0}=45^{\circ}, H=550 \mathrm{Km}$. 


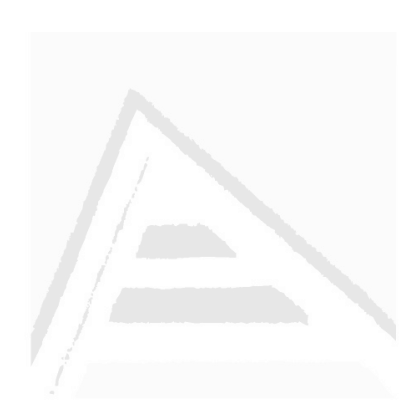

Chapter O Universitat d'Alacant

Universidad de Alicante

\section{Characterization of the EM Response of Maize Crops: Range Profiles}

AS it has been demonstrated in previous chapters, the application of existing and future inversion algorithms to the retrieval of biophysical parameters from vegetation covers is founded on an a priori knowledge of the morphology and physical characteristics of its constitutive elements. This is specially the case with microwave active remote sensing, since the high penetration of the electromagnetic waves at these frequencies makes the backscatter very dependent on the whole vegetation structure, and not only on its upper layer as in other cases (e.g. optical sensors, lidar, etc.). Hence, it is important to analyze the electromagnetic response of the vegetation volume in order to build accurate direct models which enable the derivation of retrieval algorithms.

Although operational remote sensing applications are based on air- and space-borne sensors, in many cases the development of models and algorithms is supported by experiments carried out with ground-based and indoor systems. In this context, radar measurements obtained in well-controlled conditions are also very useful for a ground-truth validation of retrieval techniques. A number of examples can be consulted in the literature, with radar systems operating in scatterometric [ZWM86, PBR+88, ZBOM89, UWD90, Bou91] and imaging [FS99, ZBSO4] modes.

Hence, the evident interest in developing robust estimation procedures for crop monitoring, together with the small amount of research on the influence of the differential extinction, have motivated the study presented in this chapter. We have analyzed backscattered data measured in laboratory conditions in order to gain understanding about the wave propagation inside the vegetation volume. Measurements are acquired with a wide-band polarimetric radar, which provides high spatial resolution for analyzing the response of the different parts of the plants inside the above-ground volume. As will be explained in the text, backscatter profiles along the slant-range coordinate have been computed and compared for different bands and polarizations. The analysis has proved to be useful from both qualitative and 
quantitative points of view. However, the experiment used only a single sample of maize, so extrapolating the interpretations and conclusions to other crop kinds or even to maize in different conditions is not a straightforward task.

Topics that have been studied cover the layered structure of the target [GD04], the randomness of the above-ground volume, and the frequency dependence of the radar response. Moreover, the influence of the differential extinction coefficient has been observed. An approach to retrieving this parameter from indoor wide-band polarimetric data has been proposed and tested. The first part of the study is based on power profiles in the linear $(\mathrm{V}-\mathrm{H})$ and the Pauli basis. The second part of the analysis treats the results obtained when applying the polarimetric target decomposition proposed in [CP97] to the profiles. The evolution of alpha, entropy and anisotropy as the wave penetrates into the vegetation volume provides information about the scattering processes present in the target and how they are observed by the radar.

The chapter is organized as follows. Section 6.1 describes the experiment and the data processing to obtain the backscatter profiles. All the results are presented and discussed in Section 6.2. Finally, the main conclusions are summarized in Section 6.3.

\subsection{Methodology and Experiment Description}

\subsubsection{Experimental Data}

The measured corn sample consists of a group of $6 \times 6$ young plants about $1.8 \mathrm{~m}$ high, uniformly planted in a square container of side length $2 \mathrm{~m}$. More details on the corn sample as well as the measurement set-up are provided in Section 5.3.1. In this experiment, the frequency ranged from 1.5 to $9.5 \mathrm{GHz}$.

It is important to note that at the time of the experiment no other ground truth was acquired, so important parameters of plants (e.g. water content) and soil (e.g. moisture and roughness) are not available for potential modelling and retrieval purposes. Although this lack of ground truth data limits the generalization of the results, the main conclusions derived here provide an important insight into the scattering processes characterizing this particular kind of crop.

\subsubsection{Data Processing}

The analysis starts with the computation of backscatter reflectivity profiles along the slantrange direction. They are computed for each polarization (HH, VV and HV) at every azimuth position of the sample. These profiles are obtained by applying a Fourier transform to the collected data in the frequency range of interest, resulting in time domain signals. The time 
variable is directly related to the slant-range $(t=2 r / c$, where $c$ is the speed of light). Figure 6.1 describes this transformation. Note that, for simplicity, the coordinate origin in the representation of the profiles will be placed at the chamber center, and near range positions will correspond to positive coordinates.

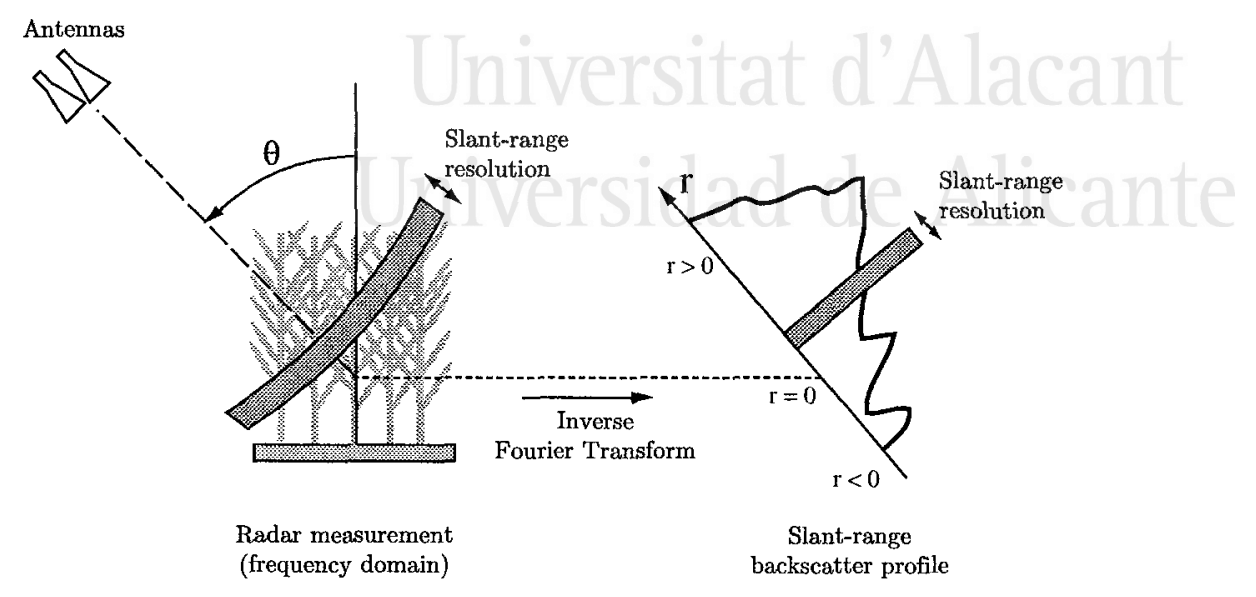

Figure 6.1: Imaging geometry and coordinate system

Target vectors $\vec{k}$ are constructed at every range bin $r$ by employing the values of the slantrange profiles. In this analysis the target vectors are expressed in both the Pauli basis and the lexicographic (or linear) basis [CP96]. From these target vectors, a position dependent coherency matrix $\langle[T]\rangle$ and a covariance matrix $\langle[C]\rangle$ are computed by averaging over the measured azimuth angles. This averaging can be applied because the sample is always at the same range from the antennas. Note again that averaging by rotating the sample in azimuth is equivalent to the conventional spatial averaging employed when dealing with radar images (maps) of a scene [MVSN94], assuming that the scene is homogeneous. Plots of the entries on the diagonal of these matrices constitute the first results to be analyzed. They correspond to profiles of the following values:

$$
\begin{aligned}
& \cdot\left\langle|H H|^{2}\right\rangle,\left\langle|V V|^{2}\right\rangle,\left\langle|H V|^{2}\right\rangle \\
& \cdot\left\langle|H H+V V|^{2}\right\rangle,\left\langle|H H-V V|^{2}\right\rangle,\left\langle|2 H V|^{2}\right\rangle
\end{aligned}
$$

In addition, the target polarimetric decomposition proposed in [CP97] has been applied to the slant-range profiles. This analysis yields an estimate of the decomposition parameters as a function of the slant-range coordinate. Therefore, we can identify the dominant scattering mechanisms associated with each height in the vegetation volume, as well as their predominance with respect to other possible mechanisms. The following parameters have been computed as a function of the height coordinate:

- Three scattering mechanisms $\alpha_{i}$ 
- Probabilities of occurrence of each scattering mechanism: $p_{i}$

- Mean scattering mechanism: $\bar{\alpha}$

. Entropy: $H$

- Anisotropy: $A$

Note that resolution is only achieved in the slant-range direction and, hence, contributions in the cross-range direction (both in azimuth and height) are integrated at each range bin. Bandwidths of $1 \mathrm{GHz}$ centered at each frequency band have been used. The corresponding resolution in slant range is about $15 \mathrm{~cm}$. Note also that no windowing has been applied in the study.

Before analyzing the results, the expected response from the target is discussed now. The finite size of the target and the square shape of the platform base entail important aspects carefully considered. The following discussion is illustrated by Figure 6.2. First of all, the backscatter profile exhibits an early time section where only volume scattering is present, starting from the upper corner of the vegetation volume which is closer to the antennas, and progressively penetrating into it. Then, there is a spread of time during which both surface and volume responses are present. Note again that the absence of vertical resolution makes the response to be a sum of signals backscattered from all parts of the target (from bottom to top): ground, stems and leaves. Finally, from the upper corner located farthest from the antennas, the volume response tends to disappear, and there is one position (the farthest range) with only ground return in the very last point. Consequently, the backscatter return exhibits a kind of "trapezoidal" shape, as depicted in the right part of Figure 6.2.

In addition, the square shape of the platform base will change the size of the incidence plane that intersects the target when it is rotated in azimuth. This variation is also illustrated in Figure 6.2 , showing the two extreme cases: $\phi=n \pi / 2$ and $\phi=\pi / 4+n \pi / 2$. The following points serve as indicators of this dependence: A (first point with volume return), B (first point with ground return), $C$ (last point with whole volume response), and D (farthest point in the sample). When $\phi=n \pi / 2$, the platform side is perpendicular to the incidence plane, and the size of the intersection is the smallest. However, when $\phi=\pi / 4+n \pi / 2$ the incidence plane crosses the target along its base diagonal, so the size of the intersection is the largest. The positions of the aforementioned characteristic points in both cases are marked with the original letters $(A, B, C, D)$ and primed letters $\left(A^{\prime}, B^{\prime}, C^{\prime}, D^{\prime}\right)$, respectively. The position of these points is included in all results to facilitate their interpretation.

\subsection{Analysis of Results}

This analysis is organized as follows. First, a study of the backscatter slant-range profiles, in both the linear and the Pauli basis, is presented. Then, a procedure to estimate the differential extinction is proposed and evaluated in Section 6.2.1.3. In Section 6.2.2 the eigenvalue 


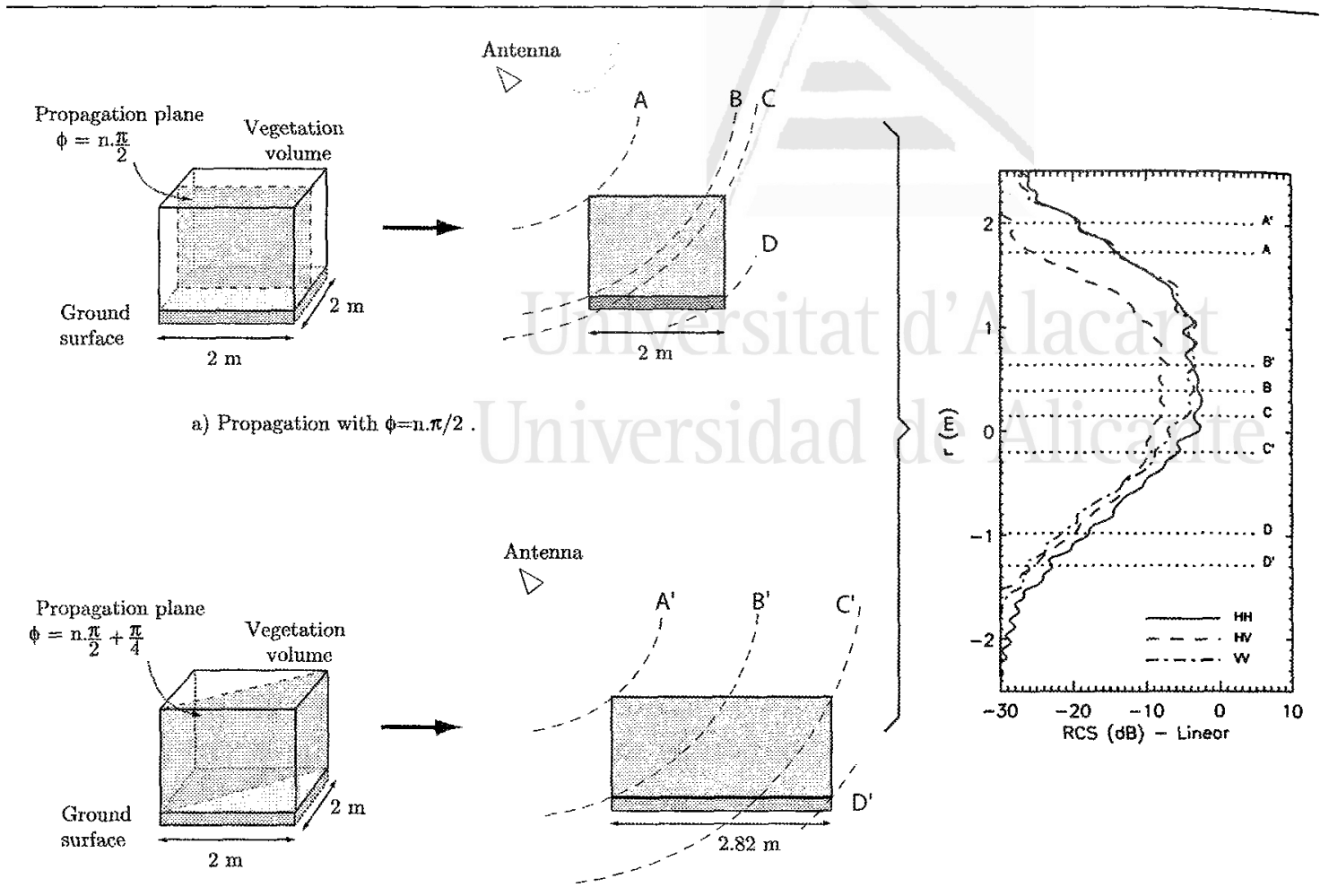

b) Propagation with $\phi=n, \pi / 2+\pi / 4$. The wave interacts with the volume in a longer path than in a).

Figure 6.2: Effect of the finite size of the target and the rotation in azimuth

decomposition of the coherency matrix is applied, and a description of the scattering behavior of the maize crop as a function of height and frequency is presented.

\subsubsection{Power Backscatter Profiles}

\subsubsection{Power Profiles in the Linear Basis}

The profiles of the reflected power in the linear (horizontal-vertical) basis are shown in Fig. 6.3 for $\mathrm{S}, \mathrm{C}$ and $\mathrm{X}$ band.

As outlined before, in all cases there is an early time section where only volume scattering is present before the surface-volume effects become significant. Then, there is a spread of time during which both surface and volume effects, and their interaction, are present. Finally, the volume response tends to disappear. During the first section (from A-A' to B-B'), the response of both copolar channels, $\mathrm{HH}$ and $\mathrm{VV}$, is the same. Then, from $\mathrm{B}-\mathrm{B}$ ' to $\mathrm{C}-\mathrm{C}$ ', as one continues the penetration through the vegetation volume and the ground starts to contribute to the backscattering, the VV signal becomes weaker than the HH signal. In all cases, the VV response is similar to the crosspolar signal (HV) at the end of the sample (from point 


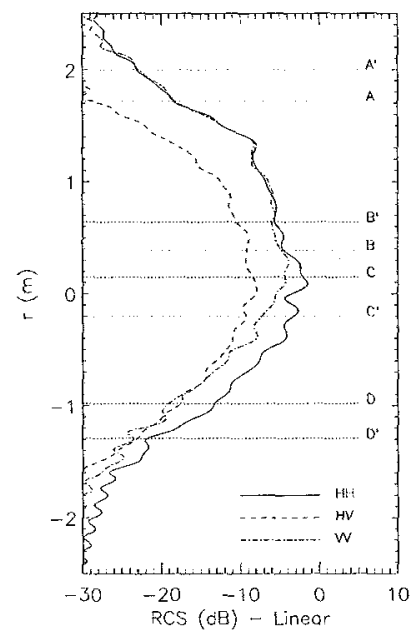

$S$ band

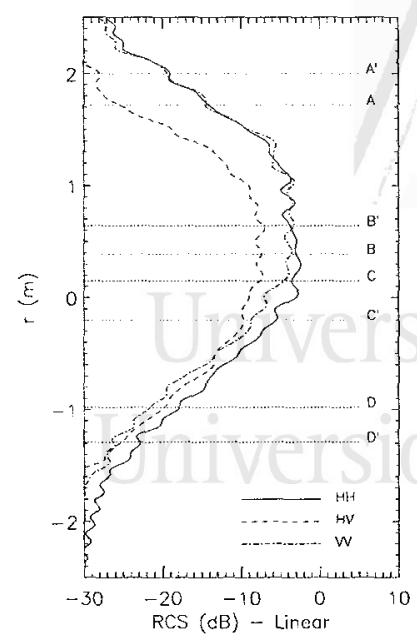

$\mathrm{C}$ band

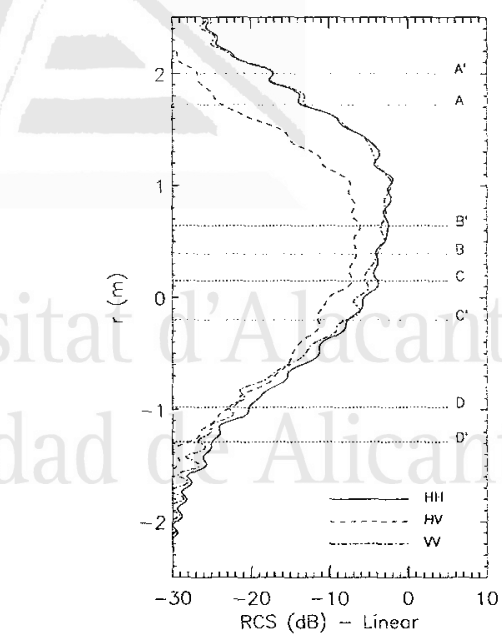

$\mathrm{X}$ band

Figure 6.3: RCS profiles at linear basis ( $\mathrm{HH}, \mathrm{HV}$ and $\mathrm{VV}$ ) as a function of slant-range for $\mathrm{S}, \mathrm{C}$ and $\mathrm{X}$ band

C-C'), whereas the $\mathrm{HH}$ response still dominates the backscattering in all cases. However, the difference between the copolar returns is dependent on frequency, as we can observe from the comparison among frequency bands: the lower the frequency, the larger the difference. Figure 6.3 also reveals that for low frequencies the backscatter is distributed over the whole target, whereas for high frequencies it is more concentrated on the parts closest to the radar.

These comments are easily explained by the extinction of the electromagnetic waves. Firstly, extinction is higher for vertical polarization because the target exhibits mainly structures with vertical orientation: the stems. The difference between $\mathrm{HH}$ and VV responses is presented in Fig. 6.4 (left plot) for the three bands.

At $\mathrm{S}$ band the difference reaches $6 \mathrm{~dB}$, at $\mathrm{C}$ band the maximum difference is about $4 \mathrm{~dB}$, and for higher frequencies the separation is below $4 \mathrm{~dB}$. Note that from point $B-B$ ' to $C-C$ ' the difference between $\mathrm{HH}$ and VV presents a growing trend, which is more evident at lower frequencies. Secondly, it is known that attenuation increases with frequency. As a result, at high frequencies the response from the top layers dominates the backscattering with respect to the bottom layers. The presence of leaves starts to be important at high frequencies, and it has two consequences: both backscattering and attenuation increase, and the propagation becomes more isotropic, since they are randomly oriented. This is also demonstrated by the rise in the crosspolar return at high frequencies, as can be observed in Fig. 6.3.

With regard to the crosspolar backscatter, it is important to emphasize that the HV response is clearly below the copolar responses. This is in contrast with the important cross-polarized return from the top canopies in forests, which is comparable to the copolar response. The different behavior comes from the orientation of the vegetation volume in this vegetation sample, as opposed to the randomness of the canopy in forests. 

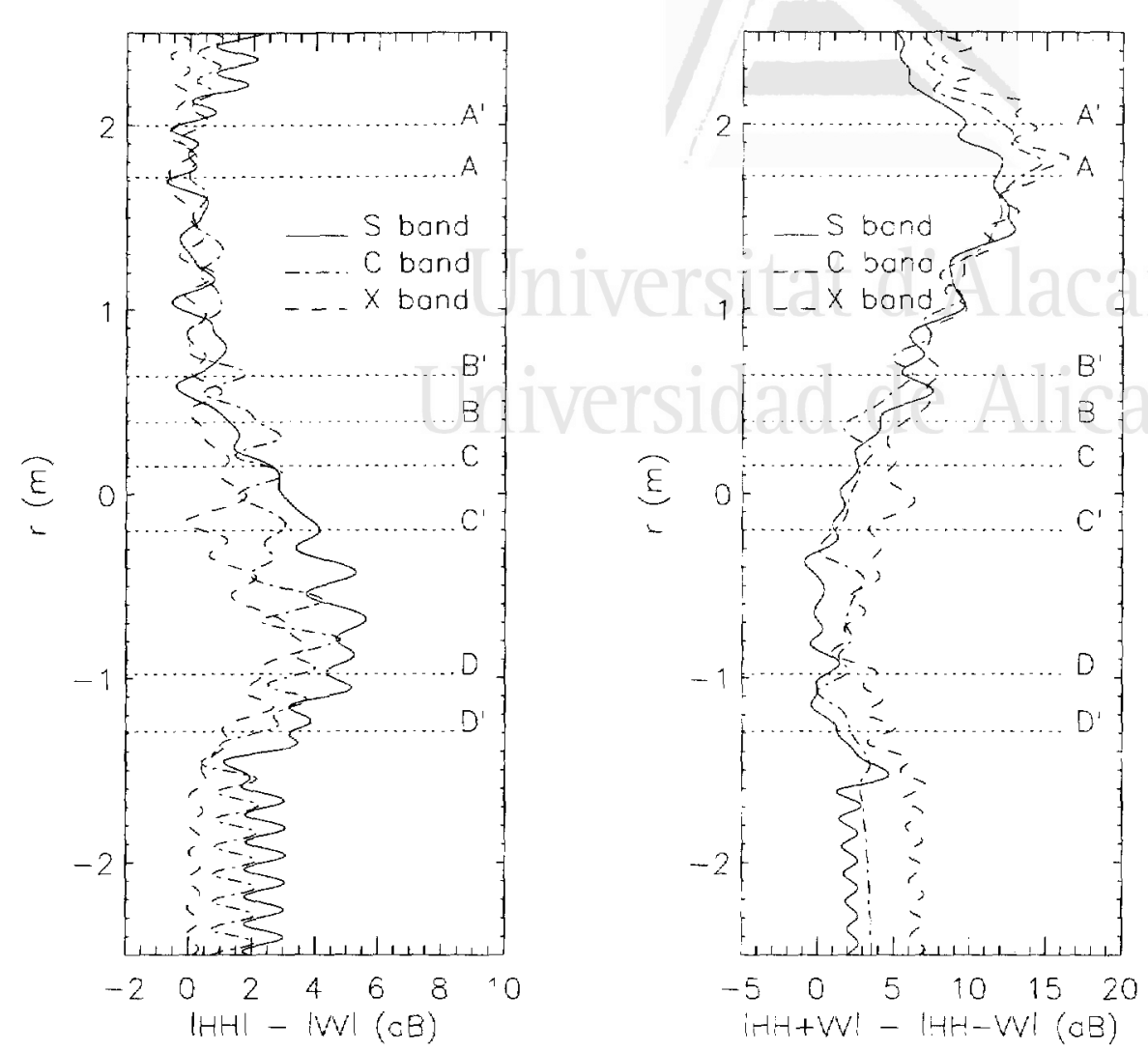

Figure 6.4: Differences in RCS between dominant polarizations at 2, 4, 6 and $8 \mathrm{GHz}$. Left: $|H H|-$ $|V V|$. Right: $|H H+V V|-|H H-V V|$

It is well known that this kind of target at this incidence angle should present an important signature from the ground-stem interaction. However, the already noted lack of height resolution causes the ground-stem contribution to be integrated together with the response of the volume. Therefore, no ground peak is evident in the results. However, the maxima of the profiles at $\mathrm{S}$ and $\mathrm{C}$ band correspond to the portion of the response where both ground and volume are present.

This interpretation of the results justifies the difference between $\mathrm{HH}$ and VV responses on the basis of differential extinction, but it leaves some aspects to be discussed. During the transition from point $A-A^{\prime}$ to point $B-B^{\prime}$, where only volume scattering is present, and differential extinction should start to affect the propagation, no significant accumulated difference between copolar channels is observed. However, the backscatter return from this region is influenced by both scattering and extinction. Backscattering contributions come from the stems and from the randomly oriented wide leaves carried by the stems. If backscattering is dominated by the leaves contribution in this near range zone, both copolar channels would maintain the same behavior. Moreover, scattering changes as a function of position because the portion of the target inside the range bin changes as we penetrate the vegetation sample, 
so the influence of extinction is not clearly discriminated from the power profiles. In contrast, from point B-B' we expect a constant backscattering from volume and surface because the content of the range bin does not change, and differences along slant-range should be caused by extinction.

In discussions with other researchers, an alternative interpretation to these results justifies the difference between $\mathrm{HH}$ and $\mathrm{VV}$ by the presence of the polarization dependent surface and surface-volume scattering. It is known that the surface-volume interaction presents $\mathrm{HH}$ larger than VV, as is observed in the results in Fig. 6.4. In addition, that alternative interpretation is postulated with scalar extinction (i.e. no differences between vertical and horizontal extinction). Scalar extinction would give rise to a constant difference between $\mathrm{HH}$ and $\mathrm{VV}$ in the zone limited by points B-B' and C-C'. As is seen in the central parts of the returns, there is an increasing trend from the beginning to the end of this section. In fact, the difference between $\mathrm{HH}$ and $\mathrm{VV}$ is almost constant before B-B'. The only problem is that the region with return from both ground and full volume is quite small (from 30 to $80 \mathrm{~cm}$ depending on the azimuth angle, i.e. a few resolution cells) so the differential extinction effects and the estimation proposed later in this work, are limited. In conclusion, this region from B-B' to C-C' may be too short to make any definitive statement about the existence of the differential extinction. Therefore, both possibilities (i.e. differential extinction, and surface effects plus scalar extinction) should be considered as equally valid hypotheses for explaining these observations on the available vegetation sample.

Note, however, that alternative measurement configurations could provide further information to explain more exactly the scattering effects inside the volume and to confirm which the effect of differential extinction is. Several strategies could be used for this purpose. On the one hand, the use of a more extensive vegetation sample would minimize artifacts in measurements and, additionally, a taller vegetation would offer a longer propagation path through the volume. On the other hand, the inclusion of EM absorber on ground would be helpful since it would isolate the vegetation response from ground backscattering. Another way to address this issue is by using small canonical metallic targets. In experiments carried out in laboratory conditions it is possible to place small calibration targets without modifying significantly the vegetation elements and with an acceptable backscattering power on receive. Comparison of these measurements with those corresponding to the metallic targets on the bare surface could yield information about the scattering processes inside the volume. Also higher resolution slant-range profiles could be performed if a higher signal bandwidth is available. The application of these strategies is left for future research.

\subsubsection{Power Profiles in the Pauli Basis}

Equivalent conclusions can be obtained by observing the profiles in the Pauli basis at $\mathrm{S}, \mathrm{C}$ and $\mathrm{X}$ band. Results are shown in Fig. 6.5.

At near range, the radar signal is dominated at the three frequency bands by the direct scattering from the leaves $(\mathrm{HH}+\mathrm{VV}$ ), which behaves equally for $\mathrm{HH}$ and $\mathrm{VV}$. The dihedral-type 


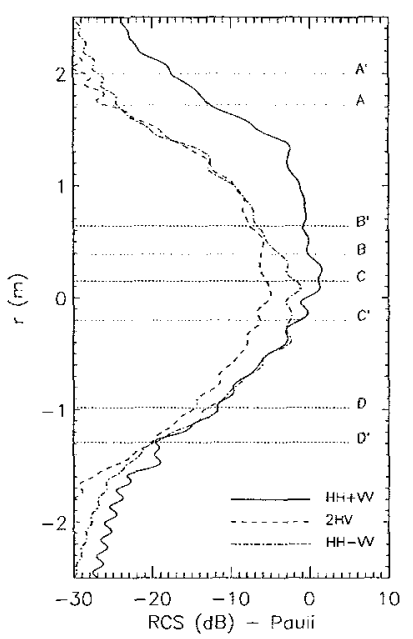

$S$ band

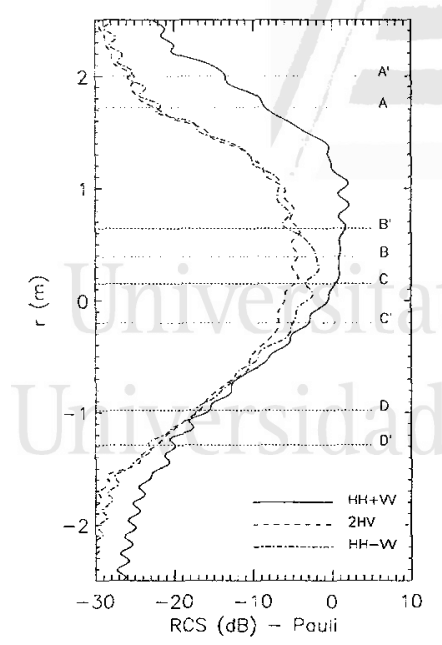

C band

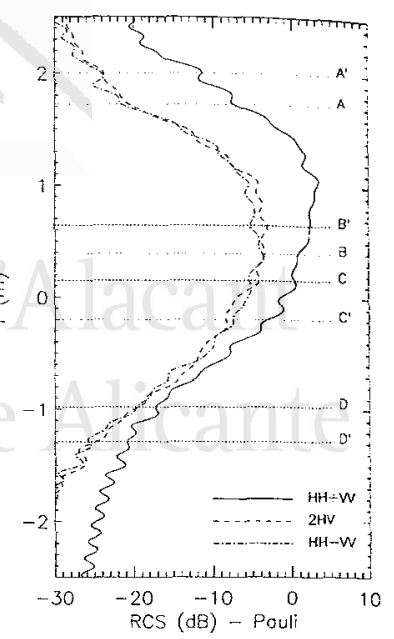

$\mathrm{X}$ band

Figure 6.5: RCS profiles at Pauli basis ( $\mathrm{HH}+\mathrm{VV}, 2 \mathrm{HV}$ and $\mathrm{HH}-\mathrm{VV})$ as a function of slant-range for $\mathrm{S}, \mathrm{C}$ and $\mathrm{X}$ band

(HH-VV) and crosspolar components are about $10 \mathrm{~dB}$ below. Then, as the wave crosses the vegetation volume, the $\mathrm{HH}-\mathrm{VV}$ response approaches $\mathrm{HH}+\mathrm{VV}$ due to the attenuation of the VV channel (they are exactly equal when VV is zero). This behavior at the farthest parts of the sample depends on the frequency band. As is observed, the higher the frequency, the lower the power of $\mathrm{HH}-\mathrm{VV}$ channel and, hence, the greater the difference with respect to the direct scattering $\mathrm{HH}+\mathrm{VV}$.

As was stated in Section 6.2.1.1, the attenuation becomes similar for both polarizations as frequency increases. This is also illustrated in Figure 6.4 (right plot) by the profiles of the difference between the two dominant terms. In this case, differences decrease as the wave travels through the sample.

It is also interesting to comment that at near range, for all bands, the crosspolar profile (HV) coincides with the dihedral-type profile (HH-VV). Backscattering is dominated by a single scattering mechanism ( $\mathrm{HH}+\mathrm{VV}$ ) in the vegetation volume, whereas other mechanisms appear when the ground is present. At $\mathrm{X}$ band the direct scattering mechanism dominates the response from the whole target.

The observation of the shape of the power profiles, shown in Figs. 6.3 and 6.5, can provide additional important considerations for PolInSAR. If the power profile of a channel is considered as an estimated probability distribution function (pdf) of the scattering center corresponding to this channel, one can derive the interferometric phase center position by looking at its mean. We have computed the heights that correspond to the averages of the power profiles, and the resulting heights are mostly coincident with the estimated heights obtained by means of interferograms computed for each channel, as in the results presented in [SLSFt $00, \mathrm{LSOO}]$. 


\subsubsection{Differential Extinction Estimation}

The trends of the differences between HH and VV profiles, shown in Fig. 6.4, suggest the possibility to relate quantitatively these curves with the extinction difference.

The propagation of an electromagnetic wave through any medium can be expressed by an exponential factor $\exp (j \beta r)$, where $r$ denotes position along the propagation direction (equivalent to the slant-range coordinate), and $\beta$ is the complex propagation constant. The real part of $\beta$ corresponds to the phase change, and the imaginary part represents any attenuation or extinction along the path. Hereafter, the extinction (imaginary part of $\beta$ ) will be denoted as $\kappa$ in order to avoid confusion with the RCS, denoted as $\sigma$ in this chapter.

If the medium exhibits some kind of orientation, then the effective propagation constants for two different polarizations become different. In that case, a diagonal propagation matrix can be used to model this effect, provided that the orthogonal polarizations employed to define this matrix are the eigenstates. In the case we are dealing with, since the medium is characterized by a vertical orientation, the eigenstates coincide with the vertical and the horizontal polarizations. As a result of this anisotropic propagation, as we have already observed with the experimental results, the extinction coefficients of these polarizations ( $\kappa_{v}$ and $\kappa_{h}$ ) are different: $\kappa_{v} \neq \kappa_{h}$. More precisely, $\kappa_{v}$ is greater than $\kappa_{h}$ for a vertically oriented volume. Therefore, one can define a differential extinction coefficient as $\kappa_{d i f f}=\kappa_{v}-\kappa_{h}$.

The profiles presented in Fig. 6.3, which have been already analyzed qualitatively, can be expressed as:

$$
\begin{aligned}
H H(\mathrm{~dB}) & =20 \log _{10}\left(\sqrt{\sigma_{h h}} \cdot e^{-2 \kappa_{h} r}\right)=10 \log _{10} \sigma_{h h}-40 \kappa_{h} r \log _{10} e \\
V V(\mathrm{~dB}) & =20 \log _{10}\left(\sqrt{\sigma_{v v}} \cdot e^{-2 \kappa_{v} r}\right)=10 \log _{10} \sigma_{v v}-40 \kappa_{v} r \log _{10} e,
\end{aligned}
$$

where $\sigma_{h h}$ and $\sigma_{v v}$ are the radar cross sections at each slant-range $r$ for horizontal and vertical polarizations, respectively. In accordance with the previous definitions, $\kappa_{h}$ and $\kappa_{v}$ are oneway attenuation rates, expressed in $(\mathrm{Np} / \mathrm{m})$.

The difference between the power profiles of the copolar terms yields:

$$
H H(\mathrm{~dB})-V V(\mathrm{~dB})=10 \log _{10}\left(\frac{\sigma_{h h}}{\sigma_{v v}}\right)+\left(40 \log _{10} e\right) \cdot\left(\kappa_{v}-\kappa_{h}\right) r
$$

If a homogeneous volume is assumed, the ratio between $\sigma_{h h}$ and $\sigma_{v v}$ is constant with $r$, and the difference between profiles, shown in (6.3), approximates to a linear function of $r$ :

$$
H H(\mathrm{~dB})-V V(\mathrm{~dB})=\text { Constant }+ \text { Slope } \cdot r,
$$

which corresponds to the linear trends shown in Fig. 6.4 (left plot).

The slope of this function is proportional to the mean differential extinction coefficient, so it 152 
can be used to retrieve this important parameter in the following way:

$$
\begin{aligned}
& \kappa_{\text {diff }}(\mathrm{Np} / \mathrm{m})=\frac{\text { Slope }(\mathrm{dB} / \mathrm{m})}{40 \log _{10} e} \\
& \kappa_{\text {diff }}(\mathrm{dB} / \mathrm{m})=20 \log _{10} e \cdot \kappa_{\text {diff }}(\mathrm{Np} / \mathrm{m})=\frac{\text { Slope }(\mathrm{dB} / \mathrm{m})}{2}
\end{aligned}
$$

This estimation approach has been applied to our experimental data, by assuming that the trends appearing in Fig. 6.4 can be approximated by a line. Of course, natural statistical fluctuations produce variability in the experimental data, so the line is fitted by a least squares approach. For this purpose, we have limited the domain to the region between the midpoints B-B' and C-C', since it is the only homogeneous region. Once again, we must highlight the limited applicability of this approach, which is very influenced by the finite size of the sample and the square shape of the platform. However, this study could be used as complementary information in the development of retrieval algorithms for oriented volumes.

The resulting estimates are represented in Fig. 6.6 as a function of frequency. Note that the maximum difference is about $2 \mathrm{~dB} / \mathrm{m}$ at $2 \mathrm{GHz}$, which explains the important anisotropic behavior of the wave propagation. As expected, the differential extinction coefficient decreases as the frequency increases.

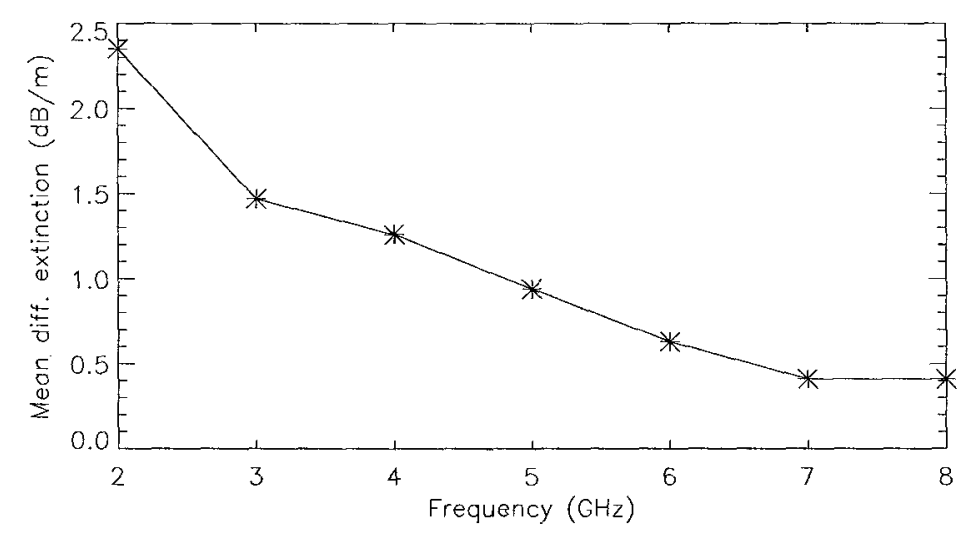

Figure 6.6: Estimated differential extinction coefficient between vertical and horizontal polarizations as a function of frequency

Unfortunately, the literature about extinction measurements with agricultural crops is rather scarce. The only experimental results suitable for comparison purposes were reported by Ulaby et al. in [UTS87]. In that work, attenuation losses for horizontally and vertically polarized waves transmitted through a corn canopy were measured at several frequencies and incidence angles. The incidence angle closest to our experiment is 40 degrees, and 1.62 $\mathrm{GHz}$ and $4.75 \mathrm{GHz}$ are also frequencies included or close to our data. At $1.62 \mathrm{GHz}$, the vertical extinction was $2 \pm 0.75 \mathrm{~dB} / \mathrm{m}$, whereas the horizontal extinction was $0.3 \pm 0.2$ 
$\mathrm{dB} / \mathrm{m}$. At $4.75 \mathrm{GHz}$ the vertical extinction was $0.9 \pm 0.8 \mathrm{~dB} / \mathrm{m}$, whereas the horizontal extinction was $0.7 \pm 0.5 \mathrm{~dB} / \mathrm{m}$. Note that the confidence intervals are quite large, so the range of possible differential extinction values is wide. If one calculates it by subtracting the vertical and the horizontal extinctions and compares it with our results at $2 \mathrm{GHz}$ and $4.75 \mathrm{GHz}$, shown in Fig. 6.6 , no definitive quantitative conclusions can be stated regarding the proposed estimation procedure.

The estimation approach presented here is only applicable to wide band radar measurements, since high resolution profiles must be computed. However, these estimates of differential extinction coefficient for this sample of corn crop could be used as a first approximation in iterative retrieval algorithms based on PolInSAR data (see Section 5.3.3).

\subsubsection{Polarimetric decomposition profiles}

The eigenvalue decomposition of the coherency matrix proposed in [CPO7] has been applied at $\mathrm{S}, \mathrm{C}$ and $\mathrm{X}$ band, and the results are plotted in Fig. 6.7. From left to right we have represented the probabilities of the 3 scattering mechanisms, the $\alpha$ angle of these mechanisms, the average $\alpha$ angle, the entropy, and the anisotropy. As expected, the differential extinction, and the other phenomena already commented, produce clear features in the profiles of the target decomposition observables.

The analysis starts with the average scattering mechanism, which is represented by the mean $\alpha$ angle. In all figures the evolution from the top to the bottom is similar: it starts at low values (close to surface-type scattering) and tends to 45 degrees, which corresponds to dipole scattering. This means that the backscattered wave becomes linearly polarized as we penetrate into the target. Again, this is evidently produced by the differential extinction coefficient already studied. Since the return is linearly polarized, the scattering mechanism would be equivalent to dipole scattering. However, as we will discuss later in the text, the entropy is very high in the results, so the estimation of average $\alpha$ angle is limited because it is known that a high entropy is always associated with $\alpha$ values around 45 degrees. Consequently, the interpretation of a dominant dipole-type scattering mechanism is not sufficiently justified from the quantitative point of view.

The slope of the transition from $\bar{\alpha} \simeq 0$ to $\bar{\alpha}=45^{\circ}$ depends strongly on the frequency. At $\mathrm{S}$ band, the transition is faster than at higher frequencies, as a consequence of the high difference between extinction coefficients. As the frequency increases, the slope is smaller. Plots of mean $\alpha$ suggest that the differential extinction coefficient between orthogonal polarizations could also be estimated by measuring the slope of the transition up to $45^{\circ}$, similarly to the estimation approach presented in the previous section. Figure 6.8 shows the measured slopes as a function of frequency. As is observed, the slope is higher at low frequencies, but the relationship between slope and differential extinction saturates for frequencies above a threshold between $S$ and $C$ band or, equivalently, for differential extinctions below $1 \mathrm{~dB} / \mathrm{m}$ approximately. 

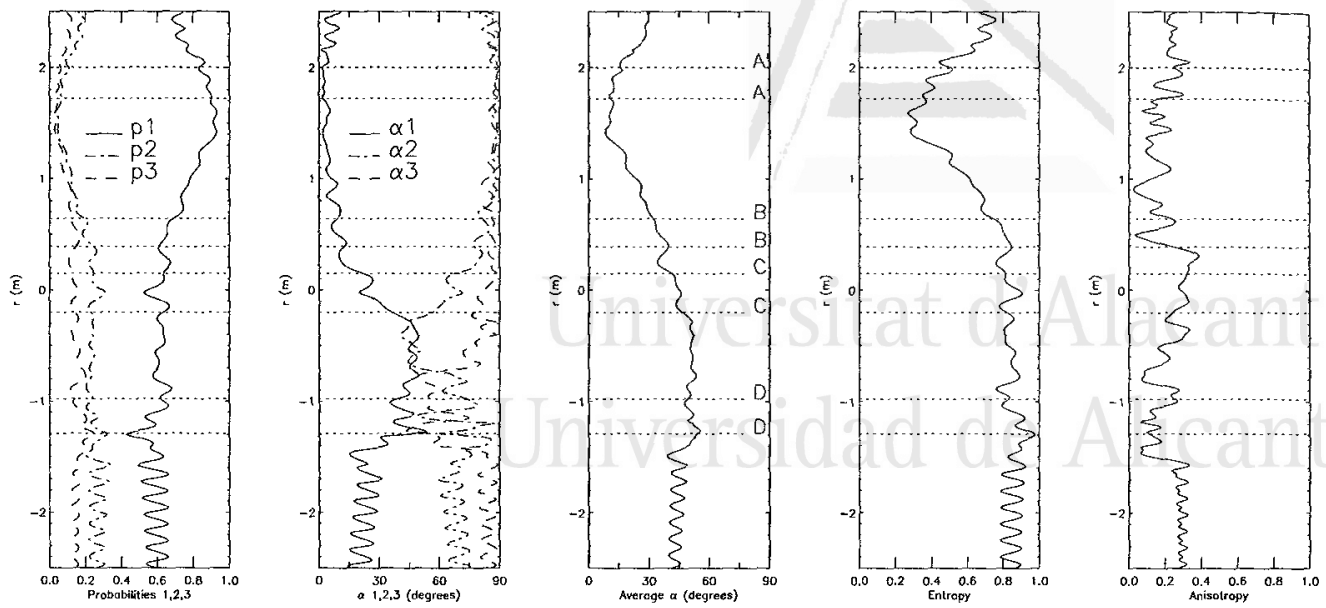

\section{S band}
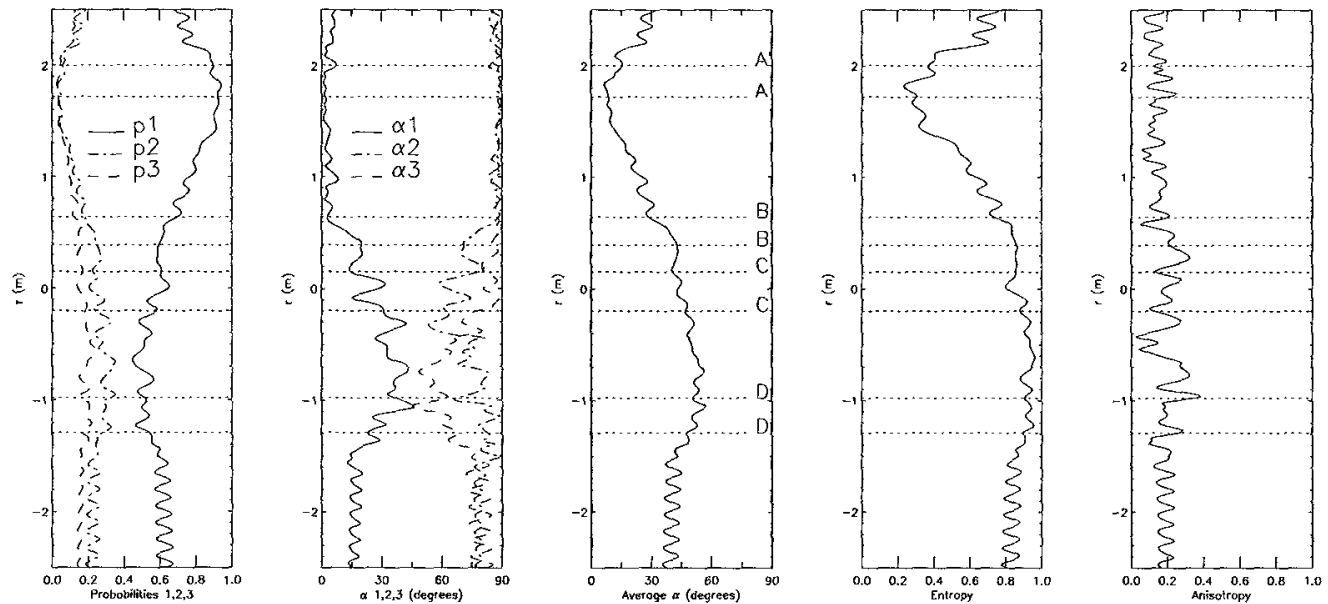

C band
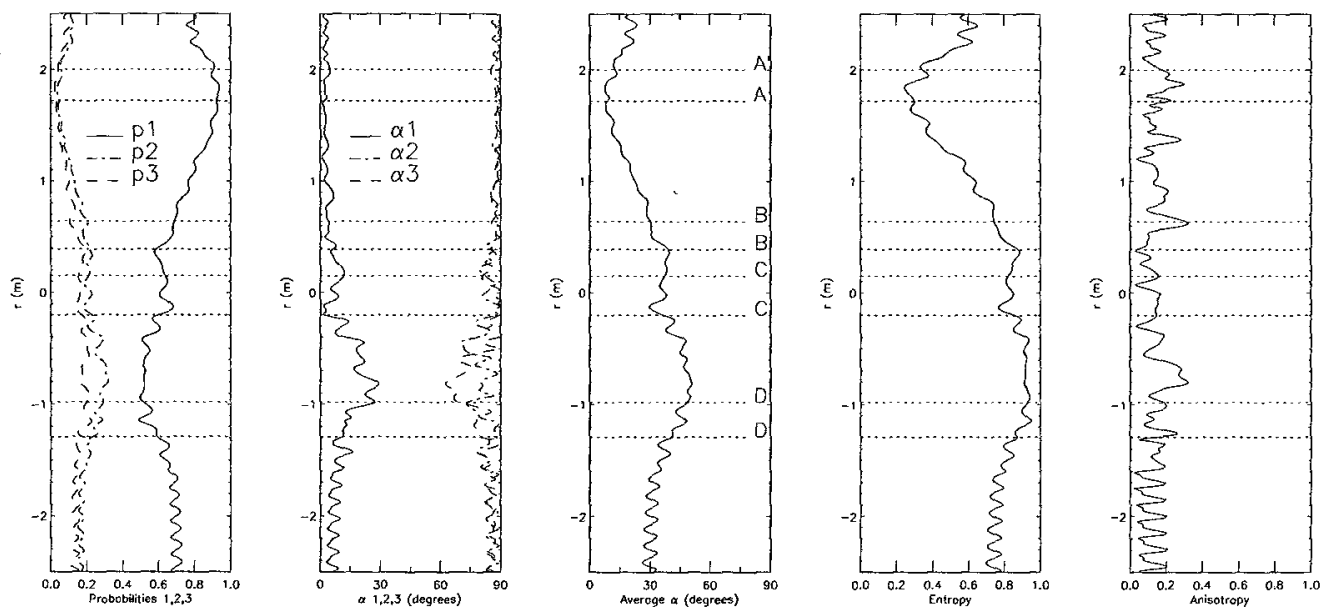

$\mathrm{X}$ band

Figure 6.7: Target decomposition parameters as a function of slant-range for $\mathrm{S}, \mathrm{C}$ and $\mathrm{X}$ band. From left to right: Probabilities of the three eigenvectors, $\alpha$ of the three scattering mechanisms, average alpha angle $\bar{\alpha}$, entropy $H$ and anisotropy $A$ 


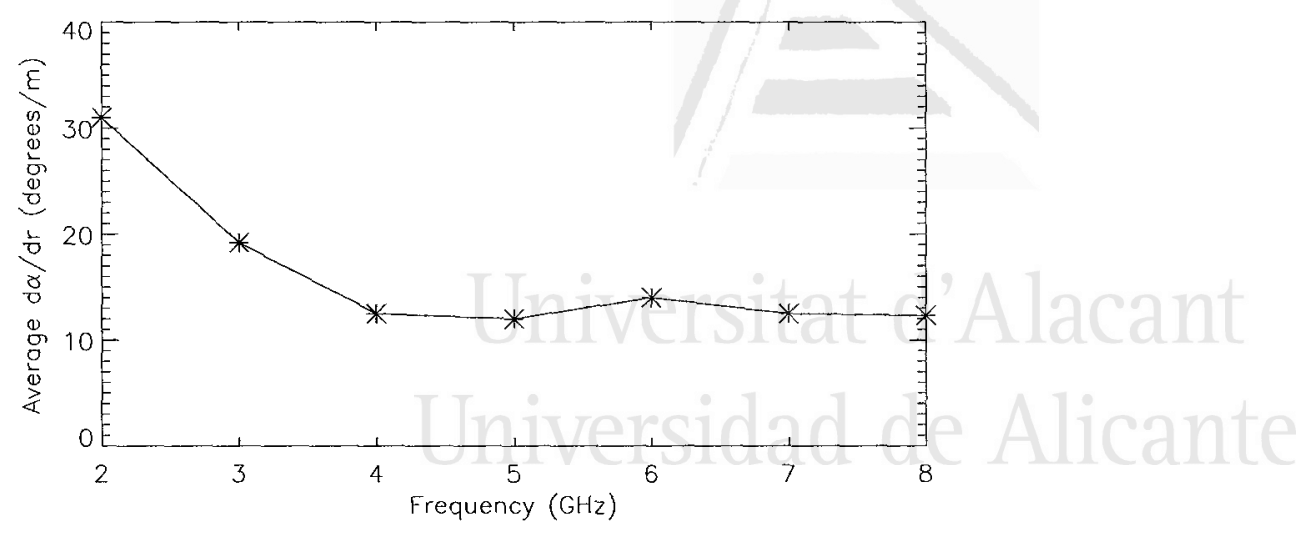

Figure 6.8: Measured slopes of $\bar{\alpha}$ with $r$, as a function of frequency

The analysis of Fig. 6.7 yields other interesting conclusions. The entropy evolution as a function of height reveals that it remains high for the three frequency bands considered (it reaches values about 0.9 ). High entropies are in agreement with the expected randomness of the scattering produced by such a natural vegetation target, despite the clear orientation of the stems and its regular plantation geometry. Note that the randomness in the scattering process should not be confounded with randomness in the orientation of the volume particles. High entropy is related with the presence of various scattering mechanisms, whereas low entropy corresponds to a single dominant mechanism. We can observe in the first figure of each row that there is a scattering mechanism with higher probability than the other two (about $2 / 3$ with respect to 1/3), but this is not a clear dominance, and the resulting entropy is high. This issue limits the applicability of the proposed approach to estimate the extinction coefficient, since three scattering mechanisms are present instead of a pure dipole process.

Another important parameter plotted in Fig. 6.7 is the anisotropy of the scattering from the corn canopy. The three scattering mechanisms are always present in the results presented here, since the anisotropy is low for S, C and X band. This effect can be also observed in the plots of the probabilities of the 2 nd and 3rd scattering mechanisms, which are very similar.

\subsection{Conclusions}

A sample of a corn field has been measured with a wide-band polarimetric radar in laboratory conditions. Backscatter profiles along slant-range reveal an expected behavior of the differential extinction coefficient, due to the vertical orientation of the plants. This extinction difference produces a linear (horizontal) polarized backscatter from the parts of the sample which are farthest from the radar. This effect is strongly frequency dependent. At low frequencies ( $S$ band), the difference between extinction coefficients is large, and it decreases as the frequency increases ( $\mathrm{X}$ band). 
The evolution of the difference between $\mathrm{HH}$ and VV radar cross sections exhibits an increasing trend as a function of slant-range. In this study it is shown that, if the medium is assumed to be homogeneous, then the slope of this observable is directly proportional to the differential extinction coefficient. This simple relationship has been also used to derive an estimation procedure for this important parameter, which has been tested with experimental data from 2 to $8 \mathrm{GHz}$. However, this estimation approach is limited by the finite size of the corn sample and by the square shape of the platform.

The target decomposition analysis of the data has been also useful for the interpretation of the scattering processes present in the sample. The differential extinction is associated with an average dipole-type scattering from the vegetation volume. The average alpha parameter evolves linearly from zero (direct surface scattering) to 45 degrees (dipole-type scattering) as the wave penetrates into the volume. In addition, high entropy values and very low anisotropies have been measured in the whole vegetation volume at all frequencies. Note that the high entropy present in the target limits the interpretation of the average alpha as a dominant dipole-type scattering, since high entropies are always associated with average alpha values around 45 degrees. The slope of average alpha is also related with the differential extinction, but it has been observed that this parameter saturates at $1 \mathrm{~dB} / \mathrm{m}$, approximately.

All these results demonstrate that an oriented volume model, which takes into account the differential extinction coefficient, should be used in retrieval algorithms with PolInSAR data for this type of agricultural crops. In this context, the differential extinction estimates obtained here can be used as complementary information for the application of an oriented volume inversion scheme [CPBO0]. 


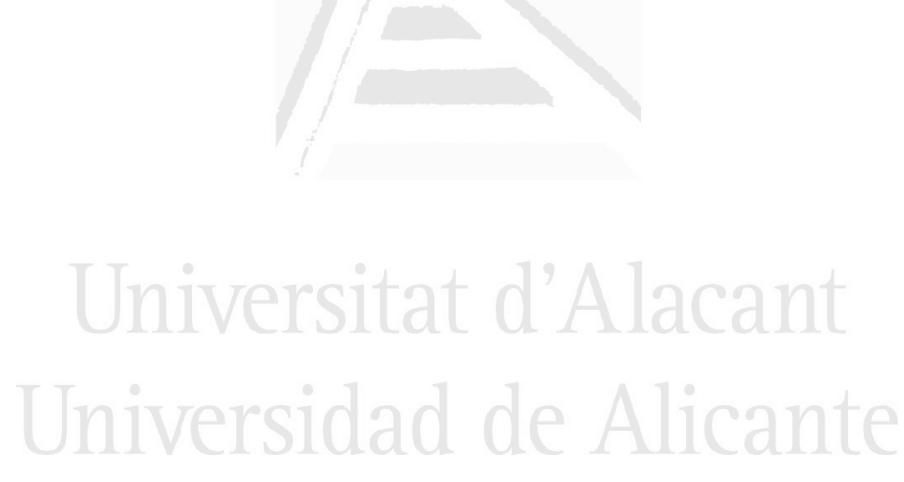

158

Tesis doctoral de la Universidad de Alicante. Tesi doctoral de la Universitat d'Alacant. 2007.

Chapter 6. Characterization of the EM Response of Maize Crops: Range Profiles

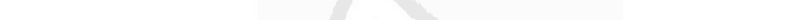

8

Retrieval of biophysical parameters of agricultural crops using polarimetric sar interferometry. Josep David Ballester Berman

(20) 


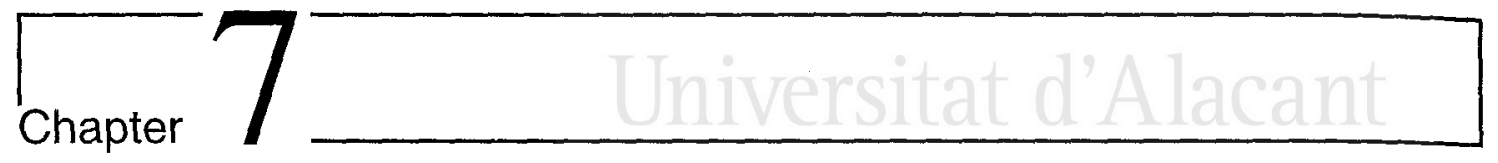

\section{Conclusions}

The work developed during this thesis is focused on the biophysical parameter retrieval from agricultural crops by means of polarimetric SAR interferometry, with special attention to corn and rice crops. Indoor wide-band fully polarimetric data of such kind of vegetation acquired at the European Microwave Signature Laboratory (EMSL), Ispra, Italy, have been used in order to test and validate the inversion capabilities of the models developed and applied during this work.

The laboratory restrictions of the measurements constrains a wide generalization of the observations and conclusions of this work. However, they constitute a valuable step towards the implementation of reliable parameter vegetation inversion algorithms, thanks to the important amount of useful information obtained for the radar characterization of agricultural crops. Before discussing the main contributions of this thesis, the objectives are briefly reviewed:

- To study and analyze the applicability of the RVoG model for the estimation of biophysical parameters for agricultural crops. This has been particularized to two cases: maize and rice.

- To develop and test an algorithm for agricultural crops modelled under the assumptions of the OVoG model. Note that the influence of the ground surface had not been previously considered in the literature, and a formal expression for the cross-correlation products in the direct model must be obtained.

- As will be observed, the inversion problem suffers from an indetermination. Therefore, some strategies for a full parameter estimation will be also investigated.

- To study and analyze the electromagnetic response of crop samples by means of power range profiles and a polarimetric analysis, as a function of wave penetration, in order to extract information about the vertical structure of this type of crop. 
Next, the main conclusions of this thesis are summarized.

In a first step, the applicability of the RVoG model for the estimation of biophysical parameters from two types of agricultural crops, namely, corn and rice plants, has been addressed. An existing inversion algorithm based on a two-layer model has been applied to retrieve volume height, ground topography and extinction coefficient. From this analysis, this inversion procedure has been studied and adapted for agricultural crops, characterized by vertically oriented structures with extinction coefficients depending on wave polarization. As a step forward in the state of the art of the electromagnetic modelling and an original contribution of this thesis, the influence of ground contribution for an oriented volume, which had not been previously treated in literature, was considered and a formal expression for the polarimetric cross-correlation products was obtained.

In this work it has been shown that, if certain conditions of the interferometer are set, the RVoG as well as the OVoG model inversion algorithms yield reasonably accurate results of ground topography and vegetation height for a wide range of configurations of frequencies and baselines. Nevertheless, it has been observed that both models are not sensitive enough to the extinction coefficient parameter and, hence, it is impossible to estimate correctly this parameter.

The conditions for a correct estimation of topography and vegetation depth can be accomplished by maintaining the $k_{z} \cdot h_{v}$ product within a certain range. On the one hand, the upper bound is fixed by the volumetric decorrelation induced by the vegetation volume. In this case, it is observed that the algorithm performs well only when the coherence is above 0.3. On the other hand, the lower bound must guarantee enough sensitivity of the interferometer to the vertical structure of the target. Assuming a constant height and a homogeneity of the target, these bounds can be controlled by means of appropiate values of baseline and frequency.

In addition, it must be noted that the physical characteristics of agricultural crops introduce other differences in radar response when compared with forested areas, which can be explained by looking at the distribution of coherences on the complex plane. Since the morphology of these plants consists of a short homogeneous volume, the backscattering power corresponds to contributions coming from the whole vegetation sample, i.e., the upper and lower layers are equally present. This is in contrast with forested areas where the response is dominated by the top canopy of trees. This behavior introduces some differences in the arrangement of the complex coherences associated with the target vectors of the Pauli basis. First, it is observed that the coherence associated with the HV channel is positioned at an intermediate zone along the linear distribution of coherences. Hence, this entails that the cross-polar channels can not be used in the inversion procedure to identify the upper layer of vegetation, as happened for forests. Actually, the HH+VV channel, which represents the direct scattering contribution, corresponds to the upper layer of the volume. Second, the coherence associated with the dihedral-like HH-VV target vector is that closest to ground, which indicates the strong contribution of the ground-stem interaction.

It must be pointed out that previous observations describe the behavior of maize crops, but 
are not directly applicable to rice fields as a consequence of the shorter volume thickness. This short volume makes the surface-stem interaction (with the soil being flooded with water) to dominate the backscattering response over the weak direct backscattering from the volume and, consequently, the complex coherences are clustered in a small region close to the unit circle. This property enables a very precise estimation of the topographic height. However, the retrieval with the line fitting is not possible at $S$ or $\mathrm{C}$ band, since the vertical wavenumber is very low in order to provide enough sensitivity to the vertical structure of rice. Indeed, a higher $k_{z}$ than for maize crops is required. Thus, an improvement of the estimation performance is obtained if the interferometer is operated above $7 \mathrm{GHz}$.

Inversion performance of the proposed algorithm has been also tested with partial polarimetric data for the corn and rice samples. In both cases it is shown that accurate results are obtained by using the coherences corresponding to direct and dihedral-type scattering, i.e. $\mathrm{HH}+\mathrm{VV}$ and HH-VV. This constitutes an important result to be accounted for in the definition of future SAR missions with capability for the coherent combination of copolar channels (e.g. TerraSAR-X, PALSAR/ALOS, Radarsat-2, TanDEM-X). Additionally, this result also emphasizes the potential of compact polarimetry concept as an effective way to overcome the limitations, i.e. swath width and bandwidth, of common dual polarized systems.

In general, it can be stated that, under certain conditions of the interferometer, inversion algorithms for both the RVoG and the OVoG models, yield reasonable results with accuracies, in the worst case, about $11 \%$ for several configurations of frequency and baseline. Furthermore, even a 5-6\% accuracy can be reached for certain configurations in the maize sample and lower accuracies than $11 \%$ for the rice sample assuming a high variability.

Regarding the vertical wavenumber requirements commented before, it can be stated that the baseline values of the InSAR system are not restrictive. For example, with the ASAR sensor of the ENVISAT mission (with a satellite height of about $800 \mathrm{~km}$, an incidence angle of $23^{\circ}$ and $5.3 \mathrm{GHz}$ of center frequency), baselines from 150 to $1000 \mathrm{~m}$ provide vertical wavenumbers between 0.1 and 0.7 , which ensure low volumetric decorrelation and enough sensitivity to the vertical structure of the target. In the particular case of ASAR, however, one has to consider the effect of the wavenumber shift, because of the narrow frequency bandwidth of Envisat ( $18 \mathrm{MHz}$ ). Consequently, the critical baseline is $1253 \mathrm{~m}$ and the maximum practical baseline assuming half the available spectrum could be set to about $600 \mathrm{~m}$, with the corresponding maximum vertical wavenumber reduced to 0.4 . These values correspond to the monostatic case. Instead, in the bistastic case, the spectral shift would be halved and, hence, the critical baseline would increase up to about $2500 \mathrm{~m}$.

In the case of TerraSAR-X (dual-pol as operational mode and quad-pol as an experimental mode), with a $300 \mathrm{~m}$ baseline, the vertical wavenumber ranges from 0.34 to 0.70 when considering incidence angles of $45^{\circ}$ and $20^{\circ}$, respectively, which are the extreme values for the stripmap mode. A $150 \mathrm{MHz}$ nominal bandwidth will be employed for X-band (it allows up to $300 \mathrm{MHz}$ in other experimental mode). On the other hand, Radarsat-2, which provides fully polarimetric capability at C-band, will use a $100 \mathrm{MHz}$ bandwidth signal. These two systems will be also operated in a near future in tandem missions (TanDEM-X, already aproved, and Radarsat-3, respectively) in order to perform single-pass interferometric mea- 
surements of the Earth's surface and, as a consequence, the temporal decorrelation term will not be present.

It is possible to extent the discussion on the baseline geometry requirements taking as initial point the maize sample studied in this thesis. Assuming a particular case with a $45^{\circ}$ incidence angle and an orbit with a height of $550 \mathrm{Km}$, the required normal baseline to wavelength ratio as a function of height is obtained. From this function the normal baseline requirement as a function of frequency for a given volume height is also obtained. It is seen that the constraint of minimum coherence is not restrictive at all since it corresponds to very high normal baselines or even non-realistic values. On the other hand, the lower bound (volume sensitivity) restricts the minimum baseline to $1700 \mathrm{~m}$ for S-band, $1300 \mathrm{~m}$ for $\mathrm{C}$-band and about 700 $\mathrm{m}$ for $\mathrm{X}$-band. Furthermore, it is seen that the critical baseline is not a limiting factor for systems with a signal bandwidth greater that $40 \mathrm{MHz}$. Assuming this signal bandwidth and the same parameters, the corresponding values of critical baseline for S, C and X-band and a monostatic interferometer are very high values $(12400,5870$ and $3240 \mathrm{~m}$, respectively). This is even more evident in a bistatic case, since the spectral shift is half the monostatic case and, hence, the critical baseline doubles. These results give an insight into the interferometer requirements but their generalization is not straightforward since, as mentioned previously, they are based on experimental observations on a specific maize sample with $1.8 \mathrm{~m}$.

The difference that appears in the OVoG model when ping-pong or single-transmit modes are used has been also object of discussion. Expressions for the polarimetric cross-correlation products have been developed for both cases, as a part of the original work of this thesis. This difference becomes evident by means of an extra decorrelation term that affects measurements in a single-transmit system and, as a consequence, the visible region of complex coherences shifts towards the origin of the complex plane. This result could be very important for the definition of future single-pass systems, such as the TanDEM-X mission, and the associated inversion algorithms.

The limitations of the direct OVoG model have been also object of research. Due to the vertical orientation of the plants, it is clear that vertical polarization exhibits the greatest extinction, whereas horizontal polarization suffers from the lowest extinction, i.e. they are the eigenpolarizations. In the representation on the complex plane of the OVoG model coherences, the eigenpolarizations are translated to two lines which define the border of the feasible region. Nevertheless, the experimental data in the linear basis are not ordered as expected, since the cross-polar coherence corresponds to a line with lower extinction than the others. This behavior is present in S-band, C-band and X-band, so it seems to come from a limitation in the direct model. This idea is supported by the fact that the matching between the visible region of coherences for the OVoG model and the measurements is only approximate.

These discrepancies between the theoretical model and the measurements arise as a consequence of the assumptions made for the electromagnetic modelling. First, the vegetation layer is assumed to be homogeneous. However, for the corn sample for example, it could be more precisely modelled as a two-layer volume. The lower one would be composed by vertically oriented stems and the upper one approximates more accurately to a random vol- 
ume. Second, the interaction among the vegetation elements has been taken into account only partially by means of a statistical modelling of the total first order backscattering from the medium and, as shown in literature, it can strongly affect the electromagnetic response of crops. Consequently, a more complete direct model would be necessary which would also take into account the backscattering coefficient, in order to compute more precisely the extinction coefficient as well as the ground-to-volume ratio.

Both the RVoG and the OVoG models establish direct relationships among radar observables and vegetation parameters. Nevertheless, these relationships are characterized by a high nonlinearity, so numerical inversion approaches suffer from variation on estimates when iterative procedures are employed. In addition, the problem becomes indeterminate for the OVoG model since there exist six observables, namely, real and imaginary parts of the complex coherences in the linear basis, and seven unkowns, i.e. volume height, ground topography, vertical and horizontal extinction coefficients, and the ground-to-volume ratio for the three polarization channels. In order to overcome this problem, three strategies for the parameter estimation have been proposed and tested.

The first approach consists in applying an existing procedure based on a linear fitting of the measured coherences on the complex plane, similarly to the original inversion technique for forests. Then, the retrieval algorithm provides estimates of the ground vertical position and the crop height, but not the extinction coefficient, which is assumed to be in a certain range of values.

Second, an hybrid approach composed by a geometrical and a numerical step is tested. The first step corresponds to the line fitting already proposed for the parameter inversion with the RVoG model, which provides an estimate of the topographic phase. The second step, that makes use of the estimated ground phase, is a genetic algorithm that yields solutions for the rest of parameters. The performance of this algorithm is strongly dependent on the initial values, and a high number of tests must be performed. Nevertheless, reasonable estimates are retrieved in a wide frequency range for various baseline configurations.

Finally, a third inversion procedure has been applied by using a dual-baseline configuration in order to increase the observation space. In this work, 2 different values for the baseline were used, which produces 12 input real data available to estimate 7 model unknowns. The solution of the model fitting has been implemented with a genetic algorithm as well. Results for the corn sample are similar to those obtained with the geometrical and hybrid approaches. However, estimates for the rice sample are not very satisfactory, since a high standard deviation of estimates is present, except for the topographic phase because of the presence of a strong backscattering from the ground-stem interaction in at least one polarization. Note that this is accomplished in the rice sample case due to the short vegetation volume.

It is important to mention that considering the similar inversion performance for vegetation height and topography of all three procedures, the use of the geometrical method would be preferable since it is much simpler to implement and it requires a low computational cost compared to the hybrid methods. 
A deep study and analysis of the electromagnetic response of a maize sample has been performed by means of power range profiles and a polarimetric analysis as a function of wave penetration in order to extract information about the vertical structure of such a crop.

On the one hand, it is observed that the evolution of the difference between $\mathrm{HH}$ and VV radar cross sections exhibits an increasing trend as a function of slant-range. Then, if the medium is assumed to be homogeneous, the slope of this observable is directly proportional to the differential extinction coefficient. This observation has been used to define an estimation procedure for this parameter from 2 to $8 \mathrm{GHz}$. Nevertheless, it must be noted that this estimation approach is limited by the finite size of the corn sample and by the square shape of the platform.

On the other hand, the target decomposition analysis of the data has revealed some interesting aspects about scattering processes in maize plants. The differential extinction is associated with an average dipole-type scattering from the vegetation volume, since the vertical polarization suffers from a higher attenuation than the horizontal polarization. Hence, the average alpha parameter evolves linearly from zero (direct surface scattering) to 45 degrees (dipoletype scattering) as the wave penetrates into the volume. In addition, high entropy values and very low anisotropies have been measured in the whole vegetation volume at all frequencies, which indicates the presence of three scattering mechanisms. As a consequence of high entropy present in the target, the interpretation of the average alpha as a dominant dipole-type scattering loses its validity, since high entropies are always associated with average alpha values around 45 degrees.

In addition, another procedure for the differential extinction coefficient has been investigated. In this case, the variation of average alpha as a function of propagation path has been related with the differential extinction, but a correct inversion is not possible since it is observed that this parameter saturates at $1 \mathrm{~dB} / \mathrm{m}$ approximately, which is a very low value of extinction.

Next, current and future lines of research are discussed.

Firstly, it would be necessary to analyze the performance of the inversion approaches addressed in this thesis with real data acquired outside the laboratory. In principle, air- or spaceborne data are affected by two limitations inherent to an InSAR system, namely, baseline and temporal decorrelation effects. The former can be eliminated by means of a spectral filtering, but it also limits the number of independent samples. Indeed, it constrains the maximum baseline and, hence, the $k_{z} \cdot h_{v}$ product to a certain value. The latter can not be eliminated and will be present in repeat-pass systems and, therefore, this will reduce the performance in the estimation process. According to this, single-pass wide-band fully polarimetric data are of prime interest for assessing the inversion capabilities of such algorithms.

Secondly, additional electromagnetic models and inversion procedures should be considered and investigated.

Regarding electromagnetic modelling, the particular morphology of some agricultural crops, such as corn and rice plants as well as the observations derived from this thesis empha- 
size the suitability of a hybrid model (random/oriented), which was presented and discussed in [UMF86, pp.1558-1573]. The crop canopy was modelled as a two-layer volume. The first layer would correspond to a random volume, since it is composed by leaves (for the corn plant) and grains and stems (for the rice plant) bent down and oriented in a random fashion. On the other hand, the second layer for both kinds of crops is mainly made up by vertical stalks. The addition of the ground surface would yield, in principle, a more accurate description of the plant, but it entails a drawback in the inversion process, since two more unkowns, i.e. the thickness of the additional upper random layer and its associated scalar extinction coefficient, should be considered compared with the homogeneous oriented volume assumption.

In order to obtain a deeper understanding of the scattering processes inside the volume, alternative measurement configurations could be used. On the one hand, the use of a more extensive and taller vegetation sample would minimize artifacts in measurements and would offer a longer propagation path through the volume. On the other hand, the inclusion of EM absorber on ground would be helpful since it would isolate the vegetation response from ground backscattering. Similarly, small canonical metallic targets can be used for this purpose in future laboratory experiments, since it is possible to place small calibration targets without modifying significantly the vegetation elements and with an acceptable backscattering power on receive. Comparison of these measurements with those corresponding to the metallic targets on the bare surface could yield information about the scattering processes inside the volume. Also higher resolution slant-range profiles could be performed if a higher signal bandwidth is available.

In addition, multiple scattering should be taken into account in order to quantify its impact in the inversion process. Note that it has been already demonstrated in previous works that first-order models underestimates the cross-polar backscattering and that the forward scattering theorem is not appropiate for wheat crops, since it overestimates the attenuation of the vertical polarization. The influence of multiple scattering in the complex coherence is not produced by the total RCS, since the intensity variations are normalized, but by the vertical profile or distribution of RCS values.

Since the definition of the interferometric coherence normalizes the RCS, the influence of multiple scattering in the coherence (both in amplitude and phase) is not produced by the total RCS, but by the vertical profile or distribution of RCS values. For example, the high resolution radar images obtained in [BOM 03 ] for wheat samples illustrate the presence of second-order volume scattering events.

The requirements of the interferometric system for crop monitoring applications should be also further investigated. Preliminary studies during the development of this thesis have been performed for a specific maize sample in laboratory conditions. The required baseline to wavelength ratio for a given volume height has been obtained. This function is constrained by two criteria which have to do with low coherence values, i.e. extreme volume decorrelation and, on the other hand, with the sensitivity of the interferometer to the vertical structure. These constraints set upper and lower bounds of the baseline to wavelength ratio. 
Also the potential of the frequency correlation function $(\mathrm{FCF})$ or $\Delta k$-radar for the parameter inversion of an oriented volume over ground surface is currently being investigated. The FCF can be seen as a multi-baseline approach, but substituting incidence diversity by frequency diversity. In the current research, the inversion process is applied by making use not only of the absolute value, as in previous works by other authors, but also of the phase information of the FCF, jointly with the complete polarimetric information provided in the linear basis, since it is assumed that the eigenpolarizations correspond to the horizontal and vertical channels. Conclusions of the first results show again that a more complete direct model is needed, in order to account more accurately for the dependence of the normalized coherence function on the extinction coefficient and the ground-to-volume ratio. It is important to note that the drawback of the FCF approach is twofold. On the one hand, it presents a limited capability for separating surface from volume effects. On the other hand, it exhibits a high dependence upon the radiating system, which makes more difficult to isolate the target response from the system one. Consequently, it is only applicable for studying certain type of targets under laboratory conditions.

Finally, further information about which are the biophysical parameters useful for end-users and which is the required accuracy in their estimation is needed. In the last part of this thesis, we have been in contact with potential end-users whose comments can serve as a guideline for future research concerning PollnSAR-based parameter retrieval techniques. With respect to plant height, it seems that the utility of crop height by its own for agricultural crop monitoring is reduced. Unlike forest applications, where the vegetation height is directly related to biomass by means of allometric equations, it is not straighforward to relate crop height to agronomic parameters, such as the Leaf Area Index, LAI, and the fraction of Absorbed Photosynthetically Active Radiation, $f A P A R$, which have to do with the energy that the plant captures from the Sun. Nevertheless, biomass is also an important parameter for crop monitoring and, consequently, a key point should be to investigate if it is possible to find the biomass by means of crop height and plant density.

Regardless the previous statements, crop height can be useful by itself in some situations. For example, it is known that rice fields in Sevilla (Spain) suffer from the effects of the eastern wind (called Llevant or Levante). When this wind blows, rice stems bend down and their upper parts come into contact with water and, hence, they decay. In this case, the height estimation could be used to identify which zones have been affected by this problem. An additional utility of height retrieval consists in using these estimates as auxiliary parameters in other different inversion techniques. Accurate height retrievals obtained by means of PolInSAR can be introduced in a radiative transfer model in order to invert other parameters more easily, such as soil moisture and roughness.

Concerning the accuracy of height estimates, it must be pointed out that it is difficult to set a value for the required accuracy since, as shown in ground-truth measurements, there exists a distribution of heights even inside a single pixel. For example, height in wheat fields can range between 70 and $80 \mathrm{~cm}$. Therefore, in this case it can be stated that a system with an accuracy about $12-14 \%$ would follow properly the corresponding profile of heights.

Another parameter whose utility should be further investigated is extinction coefficient. It is 
known that the importance of this parameter lies in its relationship, through permittivity, to water content of plants. However, from the ecological point of view, the interest is focused on water potential of plant, which is a function of the water content. This parameter is important for optimization of crop irrigation, prediction of drought seasons and forest fires, and plant pathology detection.

Summarizing, it can be stated that the main objectives of this thesis have been accomplished. This is endorsed by the discussion in international conferences and the publication in international journals of the results obtained in this research. It must be noted that part of this work deserved the First Student Paper Award in the 5th European Conference on Synthetic Aperture Radar (EUSAR) held in Ulm (Germany) in 2004.

In the next pages a list of publications is shown. 


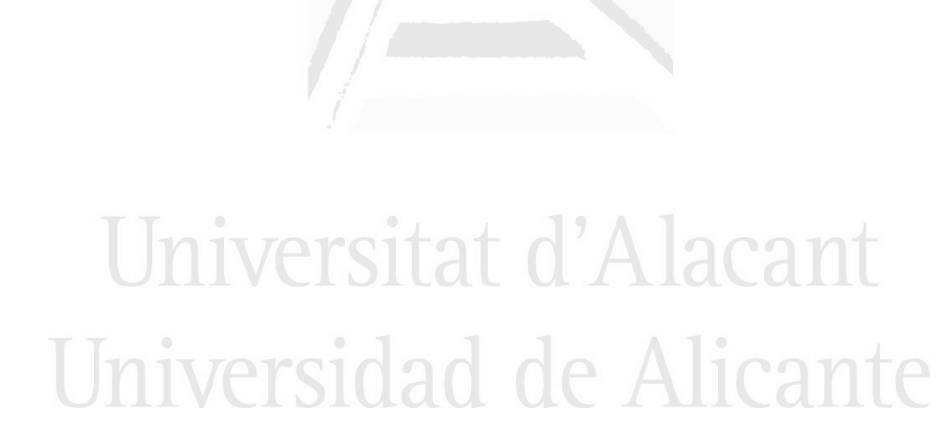
Universidad de Alicante

$\begin{array}{r}\text { Chapter } 7 \text {. Conclusions } \\ \hline\end{array}$

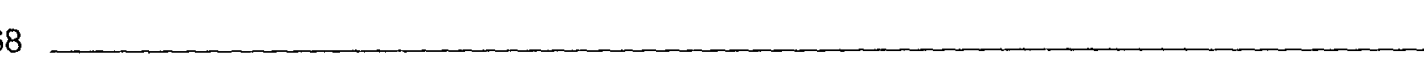

de la Univers

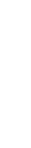

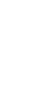

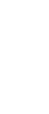




\section{Publications}

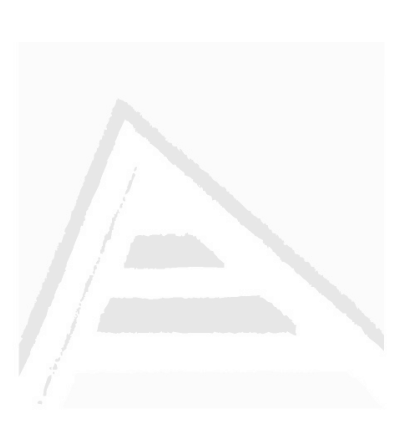

\section{Papers in Journals}

[1] J. David Ballester-Berman, Juan M. Lopez-Sanchez, and Joaquim Fortuny-Guasch, "Retrieval of Biophysical Parameters of Agricultural Crops Using Polarimetric SAR Interferometry", IEEE Trans. Geosci. Remote Sensing, vol. 43, no. 4, pp. 683-694, Apr. 2005.

[2] Juan M. Lopez-Sanchez, J. David Ballester-Berman, and Joaquim Fortuny-Guasch, "Indoor Wide-Band Polarimetric Measurements on Maize Plants: A Study of the Differential Extinction Coefficient", IEEE Trans. Geosci. Remote Sensing, vol. 44, no. 4, pp. 758-767, Apr. 2006.

[3] J. David Ballester-Berman and Juan M. Lopez-Sanchez, "Coherence Loci For A Homogeneous Volume Over A Double-Bounce Ground Return", IEEE Geoscience and Remote Sensing Letters, vol. 4, no. 2, pp. 317-321, Apr. 2007.

[4] Juan M. Lopez-Sanchez, J. David Ballester-Berman, and Yolanda Marquez-Moreno, "Model Limitations and Parameter Estimation Methods for Agricultural Applications of Polarimetric SAR Interferometry", IEEE Trans. Geosci. Remote Sensing, in press.

\section{Papers in Conferences}

[1] Juan M. Lopez-Sanchez, C. Pascual, and J. David Ballester-Berman, "On the Selection of the Best Polarization to Detect Buried Objects by Means of POLINSAR" (poster), in Proceedings of the Workshop on Applications of SAR Polarimetry and Polarimetric Interferometry (POLinSAR'2003), cdrom, Frascati, Italy, Jan. 2003.

[2] J. Fortuny, A. Martínez, D. Riccio, Juan M. Lopez-Sanchez and J. David BallesterBerman, "Experimental Validation of an Electromagnetic Model for Rice Crops Us- 
ing a Wide-Band Polarimetric Radar" (poster), in Proceedings of the IEEE International Geoscience and Remote Sensing Symposium (IGARSS'2003), pp. 2866-2868, Toulouse, France, Jul. 2003.

[3] J. Fortuny, A. Martínez, Juan M. Lopez-Sanchez, and J. David Ballester-Berman, "Electromagnetic Model of Rice Crops for Wide-Band POLINSAR" (poster), Proceedings of SPIE, vol. 5232, Barcelona, Spain, Sep. 2003.

[4] J. David Ballester-Berman, Juan M. Lopez-Sanchez, and J. Fortuny-Guasch, "Estimation of Extinction Coefficients and Its Implications in Crop Monitoring With Polarimetric SAR Interferometry" (poster), in Proceedings of the 5th European Conference on Synthetic Aperture Radar (EUSAR'2004), pp. 737-740, Ulm, Germany, May 2004.

[5] J. David Ballester-Berman, Juan M. Lopez-Sanchez, and J. Fortuny-Guasch, "Retrieval of Height and Topography of Corn Fields by Polarimetric SAR Interferometry", in Proceedings of the IEEE International Geoscience and Remote Sensing Symposium (IGARSS'2004), pp. 1228-1231, Anchorage, USA, Sep. 2004.

[6] Juan M. Lopez-Sanchez, J. David Ballester-Berman, and J. Fortuny-Guasch, "Characterization of the Electromagnetic Response of Maize Crops with 1-D Polarimetric Radar Images", in Proceedings of the IEEE International Geoscience and Remote Sensing Symposium (IGARSS'2004), pp. 200-203, Anchorage, USA, Sep. 2004.

[7] E. Ungria, J. David Ballester-Berman, and Juan M. Lopez-Sanchez, "Quality Assessment of the Oriented Volume over Ground (OVoG) Model for POLINSAR Retrieval Algorithms Applied to Agricultural Crops" (poster), Proceedings of the 2nd International Workshop on Applications of SAR Polarimetry and Polarimetric Interferometry (POLinSAR'2005), cdrom, Frascati, Italy, Jan. 2005.

[8] J. David Ballester-Berman, Juan M. Lopez-Sanchez, and J. Fortuny-Guasch, "A POLINSAR Retrieval Algorithm Applied to Rice Crops", Proceedings of the 2nd International Workshop on Applications of SAR Polarimetry and Polarimetric Interferometry (POLinSAR'2005), cdrom, Frascati, Italy, Jan. 2005.

[9] Juan M. Lopez-Sanchez and J. David Ballester-Berman, "Analysis of Numerical Approaches for a Complete Estimation of Parameters in Agricultural Crops Applications Using Polarimetric SAR Interferometry", Proceedings of URSI Commission F Symposium on Microwave Remote Sensing of the Earth, Oceans, Ice and Atmosphere, Ispra, Italy, Apr. 2005

[10] Juan M. Lopez-Sanchez, E. Ungria, J. David Ballester-Berman, and J. Fortuny-Guasch, "Advances in POLINSAR Retrieval Algorithms of Agricultural Crops", in Proceedings of the IEEE International Geoscience and Remote Sensing Symposium (IGARSS'2005), pp. 1101-1104, Seoul, Korea, Jul. 2005.

[11] J. David Ballester-Berman and Juan M. Lopez-Sanchez, "Using The Polarimetric Complex Frequency Correlation Function of An Oriented Volume For The Estimation of Agricultural Crops Parameters", in Proceedings of the 6th European Conference on Synthetic Aperture Radar (EUSAR'2006), cdrom, Dresden, Germany, May 2006. 
[12] Juan M. Lopez-Sanchez and J. David Ballester-Berman, "Model Assessment and Inversion Limitations of Polarimetric SAR Interferometry Applied to Crop Monitoring", in Proceedings of the 6th European Conference on Synthetic Aperture Radar (EUSAR'2006), cdrom, Dresden, Germany, May 2006.

[13] Juan M. Lopez-Sanchez and J. David Ballester-Berman, "Complete Inversion of Agricultural Vegetation Parameters by Pol-InSAR: Multibaseline and $\triangle \mathrm{k}$-radar Approaches", in Proceedings of the IEEE International Geoscience and Remote Sensing Symposium (IGARSS'2006), vol. 8, pp. 4036-4039, Denver, CO, EE.UU., 31 July - 4 August, 2006.

[14] J. David Ballester-Berman, Juan M. Lopez-Sanchez, and Yolanda Marquez, "Complex Interferometric Coherence Loci for the RVoG and OVoG Models With a Dominant Double-bounce Scattering in a Single-transmit Acquisition Mode", Proceedings of the 3rd International Workshop on Applications of SAR Polarimetry and Polarimetric Interferometry (POLinSAR'2007), cdrom, Frascati, Italy, Jan. 2007. 


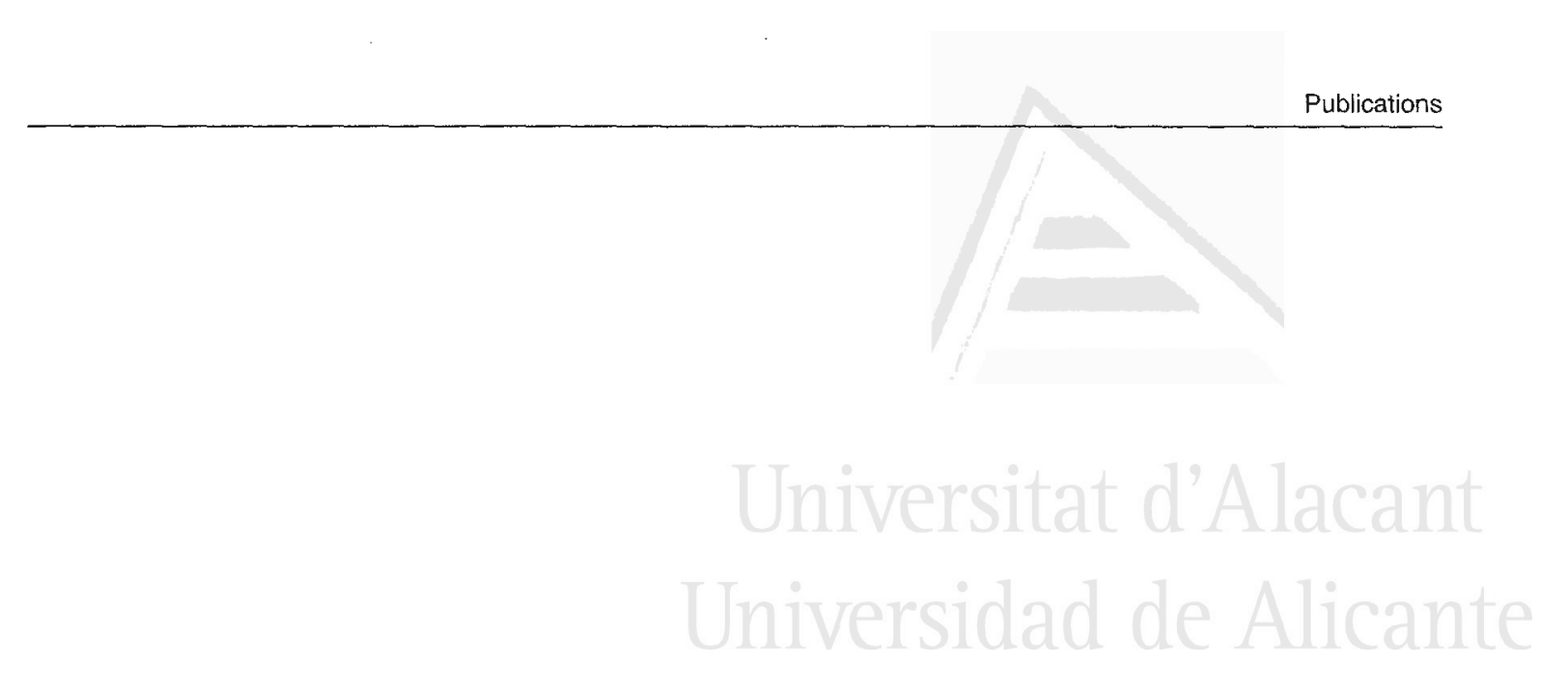

.

Tesis doctoral de la Universidad de Alicante. Tesi doctoral de la Universitat d'Alacant. 2007. 


\section{Bibliography}

[ADUS97] J. I. H. Askne, P. B. G. Dammert, L. M. H. Ulander, and G. Smith. C-band repeat-pass interferometric SAR observations of the forest. IEEE Trans. Geosci. Remote Sensing, 35(1):25-35, Jan. 1997.

[AFFP03] S. Allain, L. Ferro-Famil, and E. Pottier. Surface parameters retrieval from polarimetric and multi-frequency SAR data. In Proceedings of the IEEE International Geoscience and Remote Sensing Symposium (IGARSS), Toulouse, France, July 2003.

[AFFP04] S. Allain, L. Ferro-Famil, and E. Pottier. Two novel surface model based inversion algorithms using multi-frequency polSAR data. In Proceedings of the IEEE International Geoscience and Remote Sensing Symposium (IGARSS), Anchorage, Alaska, USA, Sept. 2004.

[AU78] E. P. W. Attema and F. T. Ulaby. Vegetation modelled as a water cloud. Radio Science, 13(2), 1978.

[BA01] L. A. Bessette and S. Ayasli. Ultra wide band p-3 and carabas II foliage attenuation and backscatter analysis. In Proceedings of IEEE Radar Conference, pages 357-362, Atlanta, USA, Jan. 2001.

$\left[\mathrm{BDW}^{+} 06\right] \quad$ X. Blaes, P. Defourny, U. Wegmüller, A. Della Vecchia, L. Guerriero, and P. Ferrazzoli. C-band polarimetric indexes for maize monitoring based on a validated radiative transfer model. IEEE Trans. Geosci. Remote Sensing, 44(4):791-800, Apr. 2006.

[BH98] R. Bamler and P. Hartl. Synthetic aperture radar interferometry. Inverse Problems, 14:R1-R54, 1998.

[Bou91] B. A. M. Bouman. Crop parameter estimation from ground-based X-band ( $3 \mathrm{~cm}$ wave) radar backscattering data. Remote Sensing of Environment, 37(3):193-205, Sept. 1991.

$\left[\mathrm{BQM}^{+} 03\right] \quad$ S. M. C. Brown, S. Quegan, K. Morrison, J. C. Bennett, and G. Cookmartin. High-resolution measurements of scattering in wheat canopies - 
implications for crop parameter retrieval. IEEE Trans. Geosci. Remote Sensing, 41(7):1602-1610, July 2003.

[BS63] P. Beckmann and A. Spizzichino, editors. The scattering of Electromagnetic waves from rough surfaces. Pergamon, 1963.

[BS87] P. Beckmann and A. Spizzichino, editors. The scattering of Electromagnetic waves from rough surfaces. Artech House, Norwood, MA, 1987.

[CFLSS99] S. R. Cloude, J. Fortuny, J. M. Lopez-Sanchez, and A. J. Sieber. Wideband polarimetric radar inversion studies for vegetation layers. IEEE Trans. Geosci. Remote Sensing, 37(5):2430-2441, Sept. 1999.

[CGM95] W. G. Carrara, R. S. Goodman, and R. M. Majewski. Spotlight Synthetic Aperture Radar. Signal Processing Algorithms. Artech House, 1995.

[Cha60] S. Chandrasekhar. Radiative Transfer. Dover, 1960.

[CK05] E. Colin-Koeniguer. Apport de la polarimétrie à l'interférométrie radar pour l'estimation des hauteurs de cibles et de paramètres de forêt. $\mathrm{PhD}$ thesis, Université Paris 6 - Pierre et Marie Curie, Paris, France, Sept. 2005 .

[Clo86] S. R. Cloude. Group theory and polarisation algebra. Optik, 75(1):26-36, 1986.

[Clo06a] S. R. Cloude. Information extraction in bistatic polarimetry. In 6 th European Conference on Synthetic Aperture Radar (EUSAR), Dresden, Germany, May 2006.

[Clo06b] S. R. Cloude. Polarisation coherence tomography. Radio Science, Apr. 2006.

[Clo06c] S. R. Cloude. Polarisation coherence tomography (PCT). In 6th European Conference on Synthetic Aperture Radar (EUSAR), Dresden, Germany, May 2006.

[Clo07] S. R. Cloude. Dual baseline coherence tomography. IEEE Geoscience and Remote Sensing Letters, 4(1):127-131, Jan. 2007.

[Cop60] J. R. Copeland. Radar target classification by polarization properties. Proc. IRE, 48:1290-1296, July 1960.

[CP95] S. R. Cloude and E. Pottier. Concept of polarization entropy in optical scattering. Optical Engineering, 34(6):1599-1610, June 1995.

[CP96] S. R. Cloude and E. Pottier. A review of target decomposition theorems in radar polarimetry. IEEE Trans. Geosci. Remote Sensing, 34(2):498-518, Mar. 1996. 
[CP97] S. R. Cloude and E. Pottier. An entropy based classification scheme for land applications of polarimetric SAR. IEEE Trans. Geosci. Remote Sensing, 35(1):68-78, Jan. 1997.

[CP98] S. R. Cloude and K. P. Papathanassiou. Polarimetric SAR interferometry. IEEE Trans. Geosci. Remote Sensing, 36(5):1551-1565, Sept. 1998.

[CP03] S. R. Cloude and K. P. Papathanassiou. Three-stage inversion process for polarimetric SAR interferometry. IEE Proc.-Radar, Sonar Navig., 150(3):125-134, June 2003.

[CPB00] S. R. Cloude, K. P. Papathanassiou, and W. M. Boerner. The remote sensing of oriented volume scattering using polarimetric radar interferometry. In Proceedings of International Symposium on Antennas and Propagation, (ISAP 2000), pages 549-552, Fukuoka, Japan, Aug. 2000.

[CSO0] T. Chiu and K. Sarabandi. Electromagnetic scattering from short branching vegetation. IEEE Trans. Geosci. Remote Sensing, 38(2):911-925, Mar. 2000.

[CYL96] W. L. Cameron, N. Youssef, and L. K. Leung. Simulated polarimetric signatures of primitive geometrical shapes. IEEE Trans. Geosci. Remote Sensing, 34(3):793-803, 1996.

$\left[\mathrm{DFCG}^{+} 05\right]$ P. Dubois-Fernandez, I. Champion, D. Guyon, H. Cantalloube, F. Garestier, X. Dupuis, and G. Bonin. Forest biomass estimation from P-band high incidence angle data. In 2nd PolInSAR workshop, Frascati, Italy, Jan. 2005.

[DSTC06] J. Du, J. Shi, S. Tjuatja, and K. S. Chen. A combined method to model microwave scattering from a forest medium. IEEE Trans. Geosci. Remote Sensing, 44(4):815-824, Apr. 2006.

[EB98] M. Engdahl and M. Borgeaud. ERS-1/2 Tandem interferometric coherence and agricultural crop height. In Proceedings of the 2 nd International Symposium on Retrieval of Bio- and Geo-physical Parameters from SAR Data for Land Applications, pages 121-127, Noordwijk, The Netherlands, Oct. 1998. ESTEC.

[EBR01] M. E. Engdahl, M. Borgeaud, and M. Rast. The use of ERS-1/2 tandem interferometric coherence in the estimation of agricultural crop heights. IEEE Trans. Geosci. Remote Sensing, 39(8):1799-1806, Aug. 2001.

[Ela88] C. Elachi. Spaceborne Radar Remote Sensing: Applications and Techniques. IEEE Press, 1988.

[FD98] A. Freeman and S. L. Durden. A three-component scattering model for polarimetric SAR data. IEEE Trans. Geosci. Remote Sensing, 36(3):963973, May 1998. 
[FGMVLSBB03] J. Fortuny-Guasch, A. Martinez-Vazquez, J. M. Lopez-Sanchez, and J.D. Ballester-Berman. Electromagnetic model of rice crops for wideband polinsar. In Proceedings of SPIE. Remote Sensing for Agriculture, Ecosystems, and Hydrology V, volume 5232, pages 635-643, Barcelona, Spain, 2003.

[FGMVR $\left.{ }^{+} 03\right]$ J. Fortuny-Guasch, A. Martinez-Vazquez, D. Riccio, J.M. LopezSanchez, and J.D. Ballester. Experimental validation of an electromagnetic model for rice crops using a wide-band polarimetric radar. In Proceedings of the IEEE International Geoscience and Remote Sensing Symposium (IGARSS), Toulouse, France, July 2003.

[For03] J. Fortuny. Improved oil slick detection and classification with polarimetric SAR. In Ist PolInSAR workshop, Frascati, Italy, Jan. 2003.

[FPPR05] A. Ferretti, D. Perissin, C. Prati, and F. Rocca. On the physical nature of SAR permanent scatterers. In Proceedings of URSI Commission F Symposium on Microwave Remote Sensing of the Earth, Oceans, Ice and Atmosphere, Ispra, Varese, Italy, Apr. 2005.

[FPR01] A. Ferretti, C. Prati, and F. Rocca. Permanent scatterers in SAR interferometry. IEEE Trans. Geosci. Remote Sensing, 39(1):8-20, Jan. 2001.

[FS99] J. Fortuny and A. J. Sieber. Three-dimensional synthetic aperture radar imaging of a fir tree: First results. IEEE Trans. Geosci. Remote Sensing, 37:1006-1014, Mar. 1999.

[FSS ${ }^{+}$03] F. Del Frate, G. Schiavon, D. Solimini, M. Borgeaud, D. H. Hoekman, and M. A. M. Vissers. Crop classification using multiconfiguration cband SAR data. IEEE Trans. Geosci. Remote Sensing, 41(7):1611-1619, July 2003.

[GD04] J. L. Gómez-Dans. On the Use of Polarimetry and Interferometry for SAR Image Analysis. PhD thesis, Sheffield Centre for Earth Observation Science (SCEOS), University of Sheffield, Sheffield, England, Feb. 2004.

$\left[\mathrm{GDFD}^{+} 05\right] \quad$ F. Garestier, P. Dubois-Fernandez, X. Dupuis, I. Hajnsek, and K. Papathanassiou. Analysis of forest parameters and agricultural field structure from high resolution polinSAR X-band data. In 2nd PolInSAR workshop, Frascati, Italy, Jan. 2005.

[GDFD ${ }^{+}$06] F. Garestier, P. Dubois-Fernandez, X. Dupuis, P. Paillou, and I. Hajnsek. Polinsar analysis of $\mathrm{x}$-band data over vegetated and urban areas. IEEE Trans. Geosci. Remote Sensing, 44(2):356-364, Feb. 2006.

[GDQB06] J. L. Gómez-Dans, S. Quegan, and J. C. Bennett. Indoor c-band polarimetric interferometry observations of a mature wheat canopy. IEEE Trans. Geosci. Remote Sensing, 44(4):768-777, Apr. 2006. 
[GGZ89] A. K. Gabriel, R. M. Goldstein, and H. A. Zebker. Mapping small elevation changes over large areas: Differential radar interferometry. J. Geophys. Res., 94(B7):9183-9191, 1989.

[GMP ${ }^{+}$94] F. Gatelli, A. Monti Guarnieri, F. Parizzi, P. Pasquali, C. Prati, and F. Rocca. The wavenumber shift in SAR interferometry. IEEE Trans. Geosci. Remote Sensing, 32(4):855-864, July 1994.

[Goo76] J. W. Goodman. Some fundamental properties of speckle. J. Opt. Soc. Am., 66(11):1145-1150, Nov. 1976.

[Gui94] A. Guissard. Mueller and Kennaugh matrices in radar polarimetry. IEEE Trans. Geosci. Remote Sensing, 32(3):590-597, May 1994.

[Han01] R. F. Hanssen. Radar Interferometry. Data interpretation and error analysis. Kluwer Academic Publishers, Dordrecht, Holland, 2001.

[HC04] I. Hajnsek and S. R. Cloude. Pol-inSAR for agricultural vegetation parameter estimation. In Proceedings of the IEEE International Geoscience and Remote Sensing Symposium (IGARSS), Anchorage, Alaska, USA, Sept. 2004.

[HC05] I. Hajnsek and S. R. Cloude. Differential extinction estimation. In 2nd PolInSAR workshop, Frascati, Italy, Jan. 2005.

[HL98] F. M. Henderson and A. J. Lewis, editors. Principles and Applications of Imaging Radar, volume 2. Wiley, 3 edition, 1998.

[HPC03] I. Hajnsek, E. Pottier, and S. R. Cloude. Inversion of surface parameters from polarimetric SAR. IEEE Trans. Geosci. Remote Sensing, 41(4):727744, Apr. 2003.

[HUA95] J. O. Hagberg, L. M. H. Ulander, and J. I. H. Askne. Repeat-pass SAR interferometry over forested terrain. IEEE Trans. Geosci. Remote Sensing, 33(2):331-340, Mar. 1995.

[Huy70] J. R. Huynen. Phenomenological Theory of Radar Targets. PhD thesis, Technical University, Delft, The Netherlands, 1970.

[Imh95] M. L. Imhoff. Radar backscatter and biomass saturation: Ramifications for global biomass inventory. IEEE Trans. Geosci. Remote Sensing, 33(2):511-518, Mar. 1995.

[JB94] D. Just and R. Bamler. Phase statistics of interferograms with applications to synthetic aperture radar. Applied Optics, 33:4361-4368, July 1994.

[JCSL05] R. Fjortoft S. Mingot J.-C. Souyris, P. Imbo and J.-S. Lee. Compact polarimetry based on symmetry properties of geophysical media: The $\pi / 4$ mode. IEEE Trans. Geosci. Remote Sensing, 43:634-646, 2005. 
[JWP94] I. R. Joughin, D. P. Winebrenner, and D. B. Percival. Probability density functions for multilook polarimetric signatures. IEEE Trans. Geosci. Remote Sensing, 32(3):562-574, May 1994.

[KC95] E. Krogager and Z. H. Czyz. Properties of the sphere, diplahe, helix decomposition. In Proceedings of Third International Workshop on Radar Polarimetry (JIPR'95), pages 106-114, Univ. Nantes, France, Mar. 1995. IRESTE.

[Ken52] E. M. Kennaugh. Polarization properties of radar reflection. Master's thesis, Dept. of Electrical Engineering, The Ohio State University, Columbus, OH, USA, 1952.

[KF88] M. A. Karam and A. K. Fung. Electromagnetic scattering from a layer of finite length, randomly oriented, dielectric, circular cylinders over a rough interface with application to vegetation. Int. J. Remote Sensing, 9(6):1109-1134, 1988.

[KFA88] M. A. Karam, A. K. Fung, and Y. M. M. Antar. Electromagnetic wave scattering from some vegetation samples. IEEE Trans. Geosci. Remote Sensing, 26(6):799-808, Nov. 1988.

$\left[\mathrm{KMF}^{+}\right.$06] G. Krieger, A. Moreira, H. Fiedler, I. Hajnsek, M. Zink, M. Werner, and M. Eineder. TanDEM-X: Mission concept, product definition and performance prediction. In 6th European Conference on Synthetic Aperture Radar (EUSAR), Dresden, Germany, May 2006.

[Kol92] M. O. Kolawole. Scattering from dielectric cylinders having radially layered permittivity. J. Electromag. Waves Appl., 6:235-259, 1992.

[Kro93] E. Krogager. Aspects of Polarimetric Radar Imaging. PhD thesis, Technical University of Denmark, Copenhagen, Denmark, 1993.

[Kro95] E. Krogager. Coherent integration of scattering matrices. In Proceedings of Third International Workshop on Radar Polarimetry (JIPR'95), pages 708-719, Univ. Nantes, France, Mar. 1995. IRESTE.

[LC94] S.-Y. Lu and R. A. Chipman. Homogeneous and inhomogeneous jones matrices. J. Optical Society of America A, 11(2), 1994.

[LHMM94] J.-S. Lee, K. W. Hoppel, S. A. Mango, and A. R. Miller. Intensity and phase statistics of multilook polarimeric and interferometric SAR imagery. IEEE Trans. Geosci. Remote Sensing, 32(5):1017-1028, Sept. 1994.

[LJD ${ }^{+}$94] J.-S. Lee, I. Jurkevich, P. Dewaele, P. Wambacq, and A. Oosterlinck. Speckle filtering of synthetic aperture radar images: A review. Remote Sensing Reviews, 8:313-340, 1994. 
[LM03] C. Lopez-Martinez. Multidimensional Speckle Noise. Modelling and Filtering Related to SAR Data. $\mathrm{PhD}$ thesis, Universitat Politècnica de Catalunya, Barcelona, Spain, 2003.

[LMP04] C. Lopez-Martinez and E. Pottier. Statistical assessment of eigenvectorbased target decomposition theorems in radar polarimetry. In Proceedings of the IEEE International Geoscience and Remote Sensing Symposium (IGARSS), Anchorage, Alaska, USA, Sept. 2004.

[LRW ${ }^{+}$97] T. Le Toan, F. Ribbes, L.-F. Wang, N. Floury, K.-H. Ding, J. A. Kong, M. Fujita, and T. Kurosu. Rice crop mapping and monitoring using ERS1 data based on experiment and modeling results. IEEE Trans. Geosci. Remote Sensing, 35(1):41-56, Jan. 1997.

[LS95]

Y.-C. Lin and K. Sarabandi. Electromagnetic scattering model for a tree trunk above a tilted ground plane. IEEE Trans. Geosci. Remote Sensing, 33(4):1063-1070, July 1995.

[LS99a] Y.-C. Lin and K. Sarabandi. A Monte Carlo coherent scattering model for forest canopies using fractal-generated trees. IEEE Trans. Geosci. Remote Sensing, 37(1):440-451, Jan. 1999.

[LS99b] Y.-C. Lin and K. Sarabandi. Retrieval of forest parameters using a fractalbased coherent scattering model and a genetic algorithm. IEEE Trans. Geosci. Remote Sensing, 37(3):1415-1424, May 1999.

[LS00] J. M. Lopez-Sanchez. Analysis and Estimation of Biophysical Parameters of Vegetation by Radar Polarimetry. PhD thesis, Polytechnic University of Valencia (UPV), Valencia, Spain, Jan. 2000.

[LSEGBEF99] J. M. Lopez-Sanchez, H. Esteban-Gonzalez, M. Baquero-Escudero, and J. Fortuny. An electromagnetic scattering model for multiple tree trunks above a tilted rough ground plane. IEEE Trans. Geosci. Remote Sensing, 37(2):659-667, Mar. 1999.

[MB04] H. McNairn and B. Brisco. The application of c-band polarimetric SAR for agriculture: a review. Can. J. Remote Sensing, 30(3), 2004.

[MBSM03] G. Margarit, P. Blanco, J. Sanz, and J. J. Mallorqui. Orbital SAR simulator of fishing vessel polarimetric signatures based on high frequency electromagnetic calculations. In Proceedings of the IEEE International Geoscience and Remote Sensing Symposium (IGARSS), Toulouse, France, July 2003.

[MDFFP05] A. Martini, J.-P. Dedieu, L. Ferro-Famil, and E. Pottier. Mapping dry snow in mountain regions from fully polarimetric sar data. In 2nd PollnSAR workshop, Frascati, Italy, Jan. 2005. 
[Men91] D. L. Mensa. High Resolution Radar Cross Section Imaging. Artech House, 2nd edition, 1991.

[MFFP04] A. Martini, L. Ferro-Famil, and E. Pottier. Multi-frequency polarimetric snow discrimination in alpine areas. In Proceedings of the IEEE International Geoscience and Remote Sensing Symposium (IGARSS), Anchorage, Alaska, USA, Sept. 2004.

[MFM04] G. Margarit, X. Fabregas, and J. J. Mallorqui. Study of the polarimetric mechanisms on simulated vessels with SAR and ISAR imaging. In 5 th European Conference on Synthetic Aperture Radar (EUSAR), volume 2, pages 603-606, Ulm, Germany, May 2004.

[Mic96] Z. Michalewicz. Genetic Algorithms + Data Structures = Evolution Programs. Springer-Verlag, 3rd edition, 1996.

[MPH04a] T. Mette, K. P. Papathanassiou, and I. Hajnsek. Applying a common allometric equation to convert forest height from pol-inSAR data to forest biomass. In Proceedings of the IEEE International Geoscience and Remote Sensing Symposium (IGARSS), Anchorage, Alaska, USA, Sept. 2004.

[MPH04b] T. Mette, K. P. Papathanassiou, and I. Hajnsek. Biomass estimation from polarimetric SAR interferometry over heterogeneous forest terrain. In Proceedings of the IEEE International Geoscience and Remote Sensing Symposium (IGARSS), Anchorage, Alaska, USA, Sept. 2004.

[MPSH07] Luca Marotti, K. Papathanassiou, R. Zandona Schneider, and I. Hajnsek. First polarimetric and interferometric results from ALOS-PalSAR. In 3rd PolInSAR workshop, Frascati, Italy, Jan. 2007.

[MR93] D. Massonet and T. Rabaute. Radar interferometry: Limits and potential. IEEE Trans. Geosci. Remote Sensing, 31(3):455-464, Mar. 1993.

[MVSN94] A. A. Monakov, J. Vivekanandan, A. S. Stjernman, and A. K. Nyström. Spatial and frequency averaging techniques for a polarimetric scatterometer system. IEEE Trans. Geosci. Remote Sensing, 32(1):187-196, Jan. 1994.

[NRT06] H. Nguyen, H. Roussel, and W. Tabbara. A coherent model of forest scattering and sar imaging in the vhf and uhf-band. IEEE Trans. Geosci. Remote Sensing, 44(4):838-848, Apr. 2006.

[OJS02] Y. Oh, Y.-M. Jang, and K. Sarabandi. Full-wave analysis of microwave scattering from short vegetation: An investigation on the effect of multiple scattering. IEEE Trans. Geosci. Remote Sensing, 40(11):2522-2526, Nov. 2002. 
[OQ98] C. Oliver and S. Quegan, editors. Understanding Synthetic Aperture Radar Images. Artech House, Boston, Mass., 1998.

[Pap84] A. Papoulis. Probability, Random Variables and Stochastic Processes. McGraw-Hill, 1984.

$\left[\mathrm{PBR}^{+} 88\right] \quad$ D. E. Pitts, G. D. Badhwar, E. Reyna, R. Zoughi, L.-K. Wu, and R. K. Moore. Estimation of X-band scattering properties of tree component. IEEE Trans. Geosci. Remote Sensing, 26(5):612-616, Sept. 1988.

[PC01] K. P. Papathanassiou and S. R. Cloude. Single baseline polarimetric SAR interferometry. IEEE Trans. Geosci. Remote Sensing, 39(11):2352-2363, Nov. 2001.

$\left[\mathrm{PCD}^{+} 05\right] \quad$ E. Pottier, S. Cloude, Y.-L. Desnos, L. Ferro-Famil, I. Hajnsek, A. Moreira, K. Papathanassiou, and T. Pearson. PolSARpro: A versatile polarimetric SAR data processing and educational toolbox. In 2nd PollnSAR workshop, Frascati, Italy, Jan. 2005.

[PHNR05] K. Papathanassiou, I. Hajnsek, T. Nagler, and H. Rott. Polarimetric SAR interferometry for snow cover parameter estimation. In 2nd PolInSAR workshop, Frascati, Italy, Jan. 2005.

[PLM03] G. Picard, T. Le Toan, and F. Mattia. Understanding C-band radar backscatter from wheat canopy using a multiple-scattering coherent model. IEEE Trans. Geosci. Remote Sensing, 41(7):1583-1591, July 2003.

[Pot98] E. Pottier. The " $H / A / \alpha$ " polarimetric decomposition approach applied to POLSAR data processing. In Proceedings of the PIERS - Workshop on Advances in Radar Methods, pages 120-122, Baveno, Italy, July 1998.

[PR93] C. Prati and F. Rocca. Improving slant-range resolution with multiple SAR surveys. IEEE Trans. Aerospace Electronic Syst., 29:135-143, June 1993.

[PRS ${ }^{+}$98] K. P. Papathanassiou, A. Reigber, R. Sheiber, R. Horn, A. Moreira, and S. R. Cloude. Airborne polarimetric SAR interferometry. In Proceedings of the IEEE International Geoscience and Remote Sensing Symposium (IGARSS), volume 4, pages 1901-1903, Seattle, WA, USA, July 1998.

[PS05] Mark Preiss and Nick J. S. Stacy. Scene coherency at x-Band from repeat pass polarimetric interferometry. In Proceedings of the IEEE International Geoscience and Remote Sensing Symposium (IGARSS), pages 1081-1084, Seoul, Korea, July 2005.

[Que94] S. Quegan. A unified algorithm for phase and cross-talk calibration of polarimetric data-theory and observations. IEEE Trans. Geosci. Remote Sensing, 32(1):89-99, Jan. 1994. 
[Ran07] R. K. Raney. Decomposition of hybrid-Polarity SAR data. In 3rd PollnSAR workshop, Frascati, Italy, Jan. 2007.

[RDUD01] R. D. De Roo, Y. Du, F. T. Ulaby, and M. C. Dobson. A semiempirical backscattering model at L-band and C-band for a soybean canopy with soil moisture estimation. IEEE Trans. Geosci. Remote Sensing, 39(4):864-872, Apr. 2001.

$\left[\mathrm{RGH}^{+}\right.$05] A. Reigber, S. Guillaso, O. Hellwich, M. Jäger, and M. Neumann. Polinsar data processing with RAT (radar tools). In 2nd PollnSAR workshop, Frascati, Italy, Jan. 2005.

$\left[\mathrm{RHJ}^{+} 00\right]$ P. A. Rosen, S. Hensley, I. R. Joughin, F. K. Li, S. N. Madsen, E. Rodríguez, and R. M. Goldstein. Synthetic aperture radar interferometry. Proceedings of the IEEE, 88(3), Mar. 2000.

[RM92] E. Rodriguez and J. M. Martin. Theory and design of interferometric synthetic aperture radars. IEE Proc.-F, 139(2):147-159, Apr. 1992.

[RM00] A. Reigber and A. Moreira. First demonstration of airborne SAR tomography using multibaseline L-band data. IEEE Trans. Geosci. Remote Sensing, 38(5):2142-2152, Sept. 2000.

[RN05] H. Rott and T. Nagler. Possibilities of radar interferometry for snow parameter retrieval. In Proceedings of URSI Commission F Symposium on Microwave Remote Sensing of the Earth, Oceans, Ice and Atmosphere, Ispra, Varese, Italy, Apr. 2005.

[Ros98] A. Rosenqvist. Effects of mechanical planting practices on L-band backscatter from irrigated rice. In Proceedings of the IEEE International Geoscience and Remote Sensing Symposium (IGARSS), volume CD-ROM, Seattle, WA, USA, July 1998.

[Sar97] K. Sarabandi. $\triangle \mathrm{k}$-radar equivalent to interferometric SAR's: A theoretical study for determination of vegetation height. IEEE Trans. Geosci. Remote Sensing, 35(5):1267-1276, Sept. 1997.

[SDR95] J.C. Shi, J. Dozier, and H. Rott. Deriving snow liquid water content using c-band polarimetric SAR. IEEE Trans. Geosci. Remote Sensing, 33(4), July 1995.

[SHLP05] R. Zandona Schneider, I. Hajnsek, A. Liseno, and K. Papathanassiou. Polarimetric interferometry over urban scenarios. In 2nd PolInSAR workshop, Frascati, Italy, Jan. 2005.

[Sin50] G. Sinclair. The transmission and reception of elliptically polarized waves. Proc. IRE, 38(2):148-151, Feb. 1950.

[Sko67] M. I. Skolnik. Introduction to Radar Systems. McGraw-Hill, 1967. 
[SL00] K. Sarabandi and Y.-C. Lin. Simulation of interferometric SAR response for characterizing the scattering phase center statistics of forest canopies. IEEE Trans. Geosci. Remote Sensing, 38(1):115-125, Jan. 2000.

[SLA99a] D. L. Schuler, J.-S. Lee, and T. L. Ainsworth. Compensation of terrain azimuthal slope effects in geophysical parameter studies using polarimetric SAR data. Remote Sensing of Environment, 69:139-155, 1999.

[SLA ${ }^{+99 b]}$ D. L. Schuler, J.-S. Lee, T. L. Ainsworth, E. Pottier, and W.-M. Boerner. Terrain slope measurement accuracy using polarimetric SAR data. In Proceedings of the IEEE International Geoscience and Remote Sensing Symposium (IGARSS), volume 5, pages 2652-2654, Hamburg, Germany, June 1999.

[SLD96] D. L. Schuler, J.-S. Lee, and G. De Grandi. Measurement of topography using polarimetric SAR images. IEEE Trans. Geosci. Remote Sensing, 34(5):1266-1276, Sept. 1996.

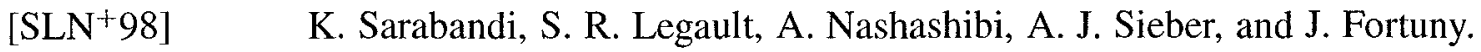
Applications of the frequency covariance function in remote sensing of environment. In Proceedings of the PIERS - Workshop on Advances in Radar Methods, pages 73-75, Baveno, Italy, July 1998.

[SLSF $\left.{ }^{+} 00\right] \quad$ L. Sagués, J. M. Lopez-Sanchez, J. Fortuny, X. Fàbregas, A. Broquetas, and A. J. Sieber. Indoor experiments on polarimetric SAR interferometry. IEEE Trans. Geosci. Remote Sensing, 38(2):671-684, Mar. 2000.

[soBmBmmfCA] Web site of BIOMASS mission (Biomass monitoring mission for Carbon Assessment). http://www.cesbio.ups-tlse.fr/us/indexbiomass.html.

[SPHM06] R. Zandoná Schneider, K. P. Papathanassiou, I. Hajnsek, and A. Moreira. Polarimetric and interferometric characterization of coherent scatterers in urban areas. IEEE Trans. Geosci. Remote Sensing, 44(4):971-984, Apr. 2006.

[SRU ${ }^{+}$99] R. Scheiber, A. Reigber, A. Ulbricht, K.P. Papathanassiou, R. Horn, S. Buckreuss, and A. Moreira. Overview of interferometric data acquisition and processing modes of the experimental airborne SAR system of DLR. In Proceedings of the IEEE International Geoscience and Remote Sensing Symposium (IGARSS), volume 1, pages 35-37, Hamburg, Germany, June 1999.

[SSU87] T. B. A. Senior, K. Sarabandi, and F. T. Ulaby. Measuring and modelling the backscattering cross section of a leaf. Radio Science, 22:1109-1116, 1987.

[SSU88] K. Sarabandi, T. B. A. Senior, and F. T. Ulaby. Effect of curvature on the backscattering from a leaf. J. Electromag. Waves Appl., 2(7):653-670, 1988. 
A. J. Sieber and Jasper W. Trevett. Comparison of multifrequency band radars for crop classification. IEEE Trans. Geosci. Remote Sensing, 21(3):285-294, July 1983.

[TBQ95] R. J. A. Tough, D. Blacknell, and S. Quegan. A statistical description of polarimetric and interferometric synthetic aperture radar data. Proc. R. Soc. Lond. A, 449:567-589, 1995.

[TC99] R. N. Treuhaft and S. R. Cloude. The structure of oriented vegetation from polarimetric interferometry. IEEE Trans. Geosci. Remote Sensing, 37(5):2620-2624, Sept. 1999.

[TC02] R. Touzi and F. Charbonneau. Characterization of target symmetric scattering using polarimetric SARs. IEEE Trans. Geosci. Remote Sensing, 40:2507-2516, 2002.

[TCD06] L. Thirion, E. Colin, and C. Dahon. Capabilities of a forest coherent scattering model applied to radiometry, interferometry, and polarimetry at $\mathrm{P}$ - and L-band. IEEE Trans. Geosci. Remote Sensing, 44(4):849-862, Apr. 2006.

[TCKJ92] L. Tsang, C. H. Chan, J. A. Kong, and J. Joseph. Polarimetric signatures of a canopy of dielectric cylinders based on first and second order vector radiative transfer theory. J. Electromag. Waves Appl., 6(1):19-51, 1992.

[TDZK90] L. Tsang, K. Ding, G. Zhang, and J. A. Kong. Backscattering enhancement and clustering effects of randomly distributed dielectric cylinders overlying a dielectric half space based on Monte-Carlo simulations. IEEE Trans. Antennas Propagat., 43(5):488-499, May 1990.

[TKD00] L. Tsang, J. A. Kong, and K.-H. Ding. Scattering of Electromagnetic Waves: Theories and Applications. Wiley Interscience, 2000.

[TKS85] L. Tsang, J. A. Kong, and R. T. Shin. Theory of Microwave Remote Sensing. Wiley Interscience, 1985.

[TMMv96] R. N. Treuhaft, S. N. Madsen, M. Moghaddam, and J. J. van Zyl. Vegetation characteristics and underlying topography from interferometric radar. Radio Science, 31(6):1449-1485, Nov. 1996.

[TS00] R. N. Treuhaft and P. R. Siqueira. Vertical structure of vegetated land surfaces from interferometric and polarimetric data. Radio Science, 35:141177,2000

[UBBLS05] E. Ungría, J. D. Ballester-Berman, and J. M. Lopez-Sanchez. Quality assessment of the oriented volume over ground (OVoG) model for polinsar retrieval algorithms applied to agricultural crops. In 2nd PolInSAR workshop, Frascati, Italy, Jan. 2005. 
[UE90] F. T. Ulaby and C. Elachi, editors. Radar Polarimetry for Geoscience Applications. Artech House, 1990.

[UMF81] F. T. Ulaby, R. K. Moore, and A. K. Fung. Microwave Remote Sensing: Fundamentals and Radiometry, volume I. Artech House, 1981.

[UMF82] F. T. Ulaby, R. K. Moore, and A. K. Fung. Microwave Remote Sensing: Radar Remote Sensing and Surface Scattering and Emission Theory, volume II. Artech House, 1982.

[UMF86] F. T. Ulaby, R. K. Moore, and A. K. Fung. Microwave Remote Sensing: From Theory to Applications, volume III. Artech House, 1986.

[USM ${ }^{+}$90] F. T. Ulaby, K. Sarabandi, K. C. McDonald, M. W. Whitt, and M. C. Dobson. Michigan microwave canopy scattering model. Int. J. Remote Sensing, 11(7):1223-1253, 1990.

[UTS87] F. T. Ulaby, A. Tavakoli, and T. B. A. Senior. Microwave propagation constant for a vegetation canopy with vertical stalks. IEEE Trans. Geosci. Remote Sensing, 25(6):714-725, Nov. 1987.

[UWD90] F. T. Ulaby, M. W. Whitt, and M. C. Dobson. Measuring the propagation properties of a forest canopy using a polarimetric scatterometer. IEEE Trans. Antennas Propagat., 38(2):251-258, Feb. 1990.

[van89] J. J. van Zyl. Unsupervised classification of scattering behavior using radar polarimetry data. IEEE Trans. Geosci. Remote Sensing, 27(1):3645, Jan. 1989.

[van90] J. J. van Zyl. Calibration of polarimetric radar images using only image parameters and trihedral corner reflector responses. IEEE Trans. Geosci. Remote Sensing, 28(3):337-348, May 1990.

[VFG ${ }^{+}$06] A. Della Vecchia, P. Ferrazzoli, L. Guerriero, X. Blaes, P. Defourny, L. Dente, F. Mattia, G. Satalino, T. Strozzi, and U. Wegmüller. Influence of geometrical factors on crop backscattering at C-band. IEEE Trans. Geosci. Remote Sensing, 44(4):778-790, Apr. 2006.

[VGBF06] A. Della Vecchia, L. Guerriero, I. Bruni, and P. Ferrazzoli. Hollow cylinder microwave model for stems: The hollow cylinder. J. Electromag. Waves Appl., 20(3):301-318, 2006.

[WSL98] C. B. Wilsen, K. Sarabandi, and Y.-C. Lin. The effect of tree architecture on the polarimetric and interferometric radar responses. In Proceedings of the IEEE International Geoscience and Remote Sensing Symposium (IGARSS), volume 3, pages 1499-1501, Seattle, WA, USA, July 1998.

[WW95] U. Wegmüller and C. L. Werner. SAR interferometric signatures of forest. IEEE Trans. Geosci. Remote Sensing, 33(5):1153-1161, Sept. 1995. 
[WW97] U. Wegmüller and C. L. Werner. Retrieval of vegetation parameters with SAR interferometry. IEEE Trans. Geosci. Remote Sensing, 35(1):18-24, Jan. 1997.

[YKJ ${ }^{+}$92] S. H. Yueh, J. A. Kong, J. K. Jao, R. T. Shin, and T. Le Toan. Branching model for vegetation. IEEE Trans. Geosci. Remote Sensing, 30(2):390402, Mar. 1992.

[YSSL04] Q. Yu, J. Shi, Y. Shao, and W. Liu. Modeling of snow wetness inversion using multi-polarization SAR at C-band. In Proceedings of the IEEE International Geoscience and Remote Sensing Symposium (IGARSS), Anchorage, Alaska, USA, Sept. 2004.

[ZBOM89] R. Zoughi, J. Bredow, S. Osman, and R. K. Moore. Fine resolution signatures of coniferous and deciduous trees at C-band. Int. J. Remote Sensing, 10(1):147-169, 1989.

[ZBS04] Z.-S. Zhou, W.-M. Boerner, and M. Sato. Development of a ground-based polarimetric broadband SAR system for noninvasive ground-truth validation in vegetation monitoring. IEEE Trans. Geosci. Remote Sensing, 42(9):1803-1810, Sept. 2004.

[ZL98] H. A. Zebker and Y. Lu. Phase unwrapping algorithms for radar interferometry: Residue-cut, least-squares and synthesis algorithms. Journal of the Optical Society of America, 15(3):586-598, Mar. 1998.

[ZV92] H. A. Zebker and J. Villasenor. Decorrelation in interferometric radar echoes. IEEE Trans. Geosci. Remote Sensing, 30(5):950-959, Sept. 1992.

[ZvH87] H. A. Zebker, J. J. van Zyl, and D. N. Held. Imaging radar polarimetry from wave synthesis. J. Geophys. Res., 92(B1):683-701, 1987.

[ZWM86] R. Zoughi, L. K. Wu, and R. K. Moore. Identification of major backscattering sources in trees and shrubs at $10 \mathrm{GHz}$. Remote Sensing of Environment, 19:269-290, 1986. 


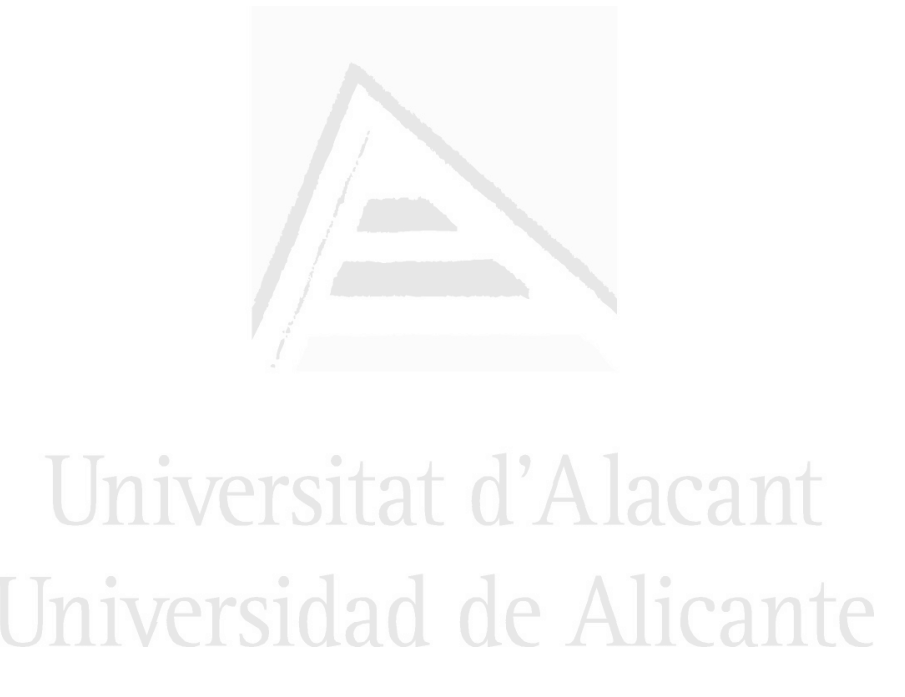

. 